\title{
DOMESDAY
}

AND FEUDAL

STATISTICS

aia

H INMAN. 


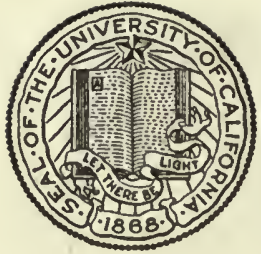

THE LIBRARY

OF

THE UNIVERSITY

OF CALIFORNIA

RIVERSIDE 

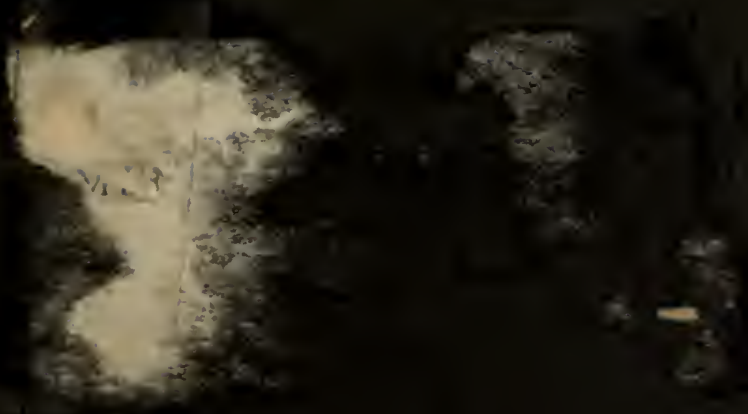
To mo piend s,g, woo is?

wite les hat wiston - Mencust anjocacceins A.1. Enis

1215723 . 


\section{DOMESDAY AND FEUDAL}

STATISTICS. 
$\therefore: \cdots$

Digitized by the Internet Archive in 2007 with funding from Microsoft Corporation 


\section{Preagntation fopt}

\section{DOMESDAY AND \\ FEUDAL STATISTICS}

WITH A CHAPTER ON

AGRICULTURAL STATISTICS

BY

A. H. I $\mathrm{N} M A \mathrm{~N}$.

Sunt gemina Somni porta quarum altera fertur Cornea quâ veris facilis datur exitus umbris Altera candenti perfecta nitens elephanto

Sed falsa ad colum mittunt insomnia mantes

VERG.

\section{Zlondon:}

ELLIOT STOCK, 62, PATERNOSTER ROW. E.C.

1900. 


\section{OF THE ORIGIN OF THE ENGLISH}

BY A. H. INMAN.

(In preparation)

Although early and external notices of the Angles, Danes, Futes, Northmen, and Saxons have not generally been esteemed worthy of inclusion in the National collection known as the Monumenta Historica Britannica, there may possibly be some reason to suppose that such are not entirely unconnected with the subject of English History, and even that a not inconsiderable portion of the present inhabitants of Great Britain have actually derived from the races aforesaid.

The period of the Roman occupation is traversed at large in the Corpus Historicum of this country named above, with a few incidental notices of some of the Germanic races, still believed to have subsequently become a material element therein : the earlier history of these is by no means to be discovered by references limited to the terms Britain or Briton, any more than that of the Franks would have been by a like restriction to the word Gaul.

So great is the obscurity of the period, that the mere fact of a settlement of England by the English, has been not unquestioned: exhaustive notices (desirable enough) of the divers races from Germania in this island, would necessitate very considerable research, nor are such intended; nevertheless, a small collection (for the more part in English), chronologically and systematically arranged, may serve, not only to confirm the ancient evidences of the acquest of this country (and in illustration of the character of the Saxons) but also-if the subject be deemed of sufficient import-as a basis for future investigations.

\section{A HISTORY OF NORTHUMBRIA}

BY A. H. INMAN. 


\section{DA 190 \\ $D 65 I 54$}

\section{PREFACE.}

The Analysis of Domesday set forth in some six Tables in this volume rests on the computations of Sir H. Ellis, and Messrs. F. Maitland and C. Pearson, the first of which is generally reliable, and practically accords with that of an independent authority (Sharon Turner).

Most essential service has recently been rendered by Professor Maitland, whose calculations of certain factors have made advance in the knowledge of our ancient Record practicable : it is not easy to overestimate the debt due to the labour of this author, but it must also be borne in mind that a computation of Hides and Carucates is a matter of much difficulty. The method used has been remarked in these pages in a note, but direct reference should be made to the computer's own remarks in Domesday Book and Beyond; although there are theories in that volume scarcely compatible with the witness of the "Survey," and 
other evidences, it is nevertheless full of interest, and should be possessed by all who have an interest in England's greatest record.

There is no reason to challenge the figures obtained from the History of England during the Middle and Early Ages, and it is believed that the Analysis of the several additions of the three above-named writers, yield generally correct information; there are also in this volume independent computations from Domesday and other sources, which claim practical rather than minute accuracy.

With regard to the Statistics of Feudal Tenures, it may be observed that the Baronial Charters of I 66 are incomplete, that the deficiencies can to some extent be supplied from the Pipe Roll of I 67-8, and that further additions (given separately), are available from other sources: these returns are corroborated by those of the Pipe Roll of 1253-4, and the Enrolled Accounts of the Exchequer for the Inquisitions of $1346-7$ (as computed by a mediæval and contemporary scribe), so that the correctness of the general result is a matter scarcely to be affected by criticism, save of the records themselves. This, of course, is to be understood rather of the plain facts elicited, than of any deductions from them containing elements 
of estimation; the latter, to a certain extent, are inevitable in the earliest (I 166-8) case, and the method, acceptable or otherwise, is set forth, but as a modus, necessitated by the defect of contemporary evidences.

A considerable amount of space is allotted to - tabular illustration, and, it is believed, that the mere arithmetical results are free from conspicuous errors, although no attempt has been made to exactly determine long series of fractions; nor can pages, so largely concerned with mere figures, attempt to compete in interest, for the general reader, with theories, elaborated by verbal art, and displayed in becoming detail.

A Statistical Index, before the text (the former perhaps also of service in demonstrating any too condensed details of latter), recapitulates and classifies some of the more important data, but rarely repeats those given only in the Tables, a list of which (arranged) precedes it: both, of course, are for convenience of reference, etc., and the former, owing to necessary brevity, does not always quite convey the sense, more precisely given in the pages alluded to.

Some sort of apology may be esteemed necessary in the presentation of pages mainly concerned 
with prosaic details; the reply must be, that in any acknowledged science, speculations, and other the usual impedimenta of extraordinary genius should be put to the ordinary tests of observation and experiment, and that there are no (or scarcely any) practical systems of knowledge, where so many theories, alike unproved and improbable, are permitted to survive, thrive, and increase, as in the accepted School of History. The practical Sciences have formulated their systems, not without labour, and by careful examinations and comparisons; the modern historian, it is true, has dismissed the wonders, signs, and portents of the mediæval world, but taking into consideration the usages and relative opportunities of the different ages, he often displays so vast an inexperience of the ordinary phenomena of the physical world, as to convict himself of a credulity much less excusable than that of an antecessor, whom it is his frequent pleasure to decry.

It may be permitted to notice some of the novelties in these pages: for example, it appears that the number of Liberi Homines and Sochemanni in Lincoln, and Norfolk (presumably also Suffolk), have been greatly overestimated, the figures in Domesday giving no direct clue as to 
the actual number of those classes; again it seems to amount to a matter of demonstration that the Carucates of Norfolk (supposedly also Suffolk), were usually neither Fiscal Units nor Teamlands.

A theory is current that the total "Service" of the Military Fees of England was equivalent to the number of Milites due from the feudal tenants in exercitu; such a doctrine has nothing a priori in its favor, save facility of computation, nor has it (so far as I am aware), any general support from records, but very much the reverse.

There is, of course, no attempt here to develope the History of the Feudal System in England; the publication of some recent volumes of the Rolls Series allowed their editor the opportunity of suggesting (and little more), at considerable length, certain views, scarcely probable in themselves, and which could not have been put forward at all, had a few elementary data, concerning the military tenures of this country, been available for general reference.

The view that one plough could, and did, till annually 120 acres of arable land, has been long established, and is, of course, completely at variance with any known practice of Agriculture in this country; as theories of this Art are usually 
held with a tenacity justly proportioned to their propounder's inexperience of the details of husbandry, it is scarcely probable that the numerous examples drawn from English records in these pages, can possibly diminish the confidence of those who allege historical evidences in support of what passes for Scholarship-to any actually acquainted with the practice of Agriculture, the appeal to records. (which uphold such) is entirely superfluous.

The curiosities of Domesday can very well be studied in Sir H. Ellis'. General Introduction and Index of Matters (Vol. III), nevertheless in writing on our ancient Record, it has (contrary to the practice of many of its exponents), been esteemed necessary to traverse it, entry by entry, for certain matters exemplified in this volume. This remark applies but partially to Little Domesday, whose technical manorial details have been almost unperused (valuable as they may be for the three counties therein contained), nor is there the least pretension towards exhausting - in any way - the contents of that unrivalled witness of Anglo-Saxon customs.

In conclusion, it should be stated that $\mathrm{Mr}$. N. J. Hone, of Surbiton, is responsible for the evi- 


\section{Preface.}

dence from unprinted materials in Chapter II, having made professional searches (to instructions, in particular records), on divers matters; references to these are given in their place, so that they can easily be tested for general accuracy; this the writer (who is responsible for the remaining extracts, etc., from records and works of authority) doès not doubt.

Wardrew House,

Gilsland,

Oct. 22, 1900. 



\section{EPITOME.}

\section{DOMESDAY STATISTICS.}

CHAPTER I (pp. I-24).

Population and Counties, p. I. Main Statistical Table, p. 5. Population 1086 and 1377, p. 5. Units of Assessment and Measures, p. 5. Plough Team, p. 6. Comparative Values of Implements and Oxen, p. 6. Ploughland, p. 7. Area not tilled by one plough, p. 7. Oxford A rithmetic, p. 8. Cullege Farming, p. 9. Valets and Valuits, p. 1o. Villani, p. 10. Opera, p. 10. Bordars and Cottars, p. II. Illustrations of same from $D . B$., p. I1. Servi, p. 12. Sokemen, p. I2. Popular estimate of Liberi Homines, and Sokemen (1086) not in accord with $D$. B. evidence, p. I2. Liberi homines, p. 12. Radknights, p. I3. Tenants in chief, p. 13. Coliberti and Buri, p. 13. Geburi not Coliberti, p. I3 Geburi as Villani, p. 16. Other Classes, p. I6. Porcarii and Bovarii, p. I6. Remarks on Comparative Table I, p. 17. Land to one team, p I7. Land of one team in demesne, and in villeinage, p. 18. Oxen per plough in Wales, $t$. Hen. II, p. r8. Teams of less than 8 oxen, p. 22. Teams of 8 oxen, p. 22. Rotations, p. 23. Method of Tables, p. 23. Population varies as Teans, p. 24. Slender results from other unlike Factors, p. 24.

\section{FEUDAL STATISTICS.}

CHAPTER II (pp. 25-109d).

Anglo-Saxou Charters, p. 26. Norman Charters, p. 26. Heptarchic Hides, p. 28. 120 statute acres arable not the land of one family, p. 29. Owners of land T.R.E. and T.R.W., p. 30. Modern theories of ancient landownership 
impracticable, p.31. Places, Manors, Vills, and Parishes 1086. I 377, p. 31. The Hide and Hidage, p. 32. Carucage, p. 33. Medizval Taxes, p. 33. Danegeld, etc., p. 34. Sheriff's Aid, p. 34. Occasional stability of Hides, p. 35. Examples of continuity of Hidage, p. 36 . Variations of Areal Hides, p. 37. Domesday "Measures," p. 38. Cornish "Acres," p. 38. Intermixture of D. B. "Measures," p. 39. Fiscal Hides in Woods and Marshes, p. 40. Yorkshire Manors, p. 4I. Scope of the Fiscal Hide, p. 4r. Knights' Fees, p. 42. Bishop of Durham's case, Service, and Retainers, p. 42. Average Fee, p. 43. Variations very considerable, p. 44. Examples, p. 44. Baronial Charters, I166, p.46. Dominicum, p. 46. Retrospective references of early enfeoffments, p. 47. Their authority, p. 48. Nigel d'Aubignie and Roger de Moubrai, p. 49. Aids of I4 Hen. II and $38 \mathrm{Hen}$. III contrasted, p. $5 \mathrm{r}$, Aid to marry King Edward's daughter, p. 52. Contemporary totalling of Knights' Fees, $t$. Ed. III, p. 53. Moubrai Fee, p. 53. Method of computing Knight's Fees of $t$. Hen. II, p. 53 . Explanation of 5 Column Table, $t$. Hen. II, p. 54. Composition of known "service," p. 55. Composition of unknown "service," p. 55. Remarks on above, p. 55. Total capital tenants by Knight Service $t$. Hen. II, p. 56. Render the usual basis of subsequent returns, p. 56. Exceptional cases, p. 57. Render, and "Service," p. 57. New Feoffment, p. 58. Excess of old feoffment on Church Fees not usually paid, p. 58. Aid to marry, I9 Hen. III, and Gascony Scutage, 1242, p. 59. Testa de Nevill, p. 59. Northumberland Inquisitions, 26 Hen. III, p. 6o. Evidence of Testa de Nevill, p. 60. Extent of alleged exactions of new feoffment, p. 6r. Evidence of Pipe Roll, 14 Hen. II, p. 62. Summary of Church Fees, I168, p. 62. Their unrecognised liabilities unpaid, and their extensive demesnes, p. 63. Liberty of Ripon, p. 64. Inadequacy of Column II, Table I, p. 64. Estimate of "Service," I 68 , p. 64. Estimate of acres in Church and Lay Fees, p. 65. Estimate of Total Fees, p. 65. Average, Hides, and Acres per Lay Fee, p. 65. Characteristic examples, p. 66. Super dominicum, p. 67. Statistics of Fees, p. 67. 
Number of Capital Tenants, contrasted with D. B., p. 68. Inquisitions, $t$. John, p. 68 . Later Inquisitions, p. 68 . Inquisitions of 1346, p. 69 . Returns of 4 Hen. IV, p. 69. Change of method-as usually only demesne fees answered in 1403, p. 70. Returns of 6 Hen. VI, p. 7I. No Assessments on Knights' Fees $t$. Hen. VII, and Jac. I, p. 7I. Further evidence from the Testa de Nevill, p. 7r. Fines, ne transfretant, p. 74. Alleged development of the Fee from the Hide, p. 74. Remarks on sanie, p. 75. Records refute this theory, p. 75. Scutagium and Auxilium, p. 8o. Early evidence defective, p. 82. Military service, p. 83 . How performed by Peterboro' Abbey, p. 84. Prior of Coventry's case, p. 85. Escuage tenants, p. 86. Disseisin, p. 87. Obligations of under tenants, p. 88. Inadequacy of entries of Scutage in the Pipe Rolls, $t$. Ed. I, p. 88. Double meaning of Service illustrated by the Luterell case, p. 89. Examples from Madox, etc., p. 9o. Payment of Scutage, p. 92. Examples from MSS, mostly unprinted, p. 93. Decline of Scutage, and its extinction in the 17th century; p. 96. Popular theory of Service in exercitu, p. 97. Unanimity of authorities thereanent, p. 97. Quotas of Service, p. 97. Army of Calais (Brady), A.D. 1346, p. 98. Service of more than roo milites, p. 99 Popular theory of Knight Service lacks support of Records, p. 99. Expenses of Military Service, p. I00، Bargains with hired Knights; actual case in 1284 , between tenant and miles, p. 100. Wages of a Knight, $t$. Hen. II, p. Ioo. Flemish Conventions, Hen. I.II, p. IOoa. Period of Service, p. IoI. Prestations, p. IoI. Army of Ireland, 1211, p. ror. to days, p. I02. Normandy Inquisitions, $\mathrm{p}$ 102. Milites in $D . B ., \mathrm{p}$. 102. Auxilium $t$. Hen. I, p. I03. Assize of Arms, $t$. Hen. II, p. 104. Alleged decay of Archery, p. 10t. Feudum Militis in Normandy, I th century, p. 104. Milites of Peterboro' Abbey, p. 105. Service of Evesham Abbey in exercitu, p. 105. The predecessor of Ranulf Flambard disseised for defect of service, etc., p. 105. Diversity of services due, p. Io6. Partial Analysis of Moreton Escheat, p. 107. Evidence of the Roman de Rou, p. 107. Fees held since the Acquest of England, p. I08. Early subinfeu. 
dations of lay tenants, p. Io8. Subinfeudation, $t$. Wm. 1, p. rog. Duke Richard's military service, p. tog. A recent American work on the Feudal System, p. Iog. A magnum opus on Ancient Britain, p. Ioga. Extracts from, and design of said work, p. Ioga. Formation of A. S. Chronicles, p. rogb. The Annals of Northumbria, p. rogc. Chroniclers, p. rogc. Introduction of Learning in the North, p. rogc. Royal Genealogies, p. Iogc. Gothic and Germanic, p. Iogc. Goths, Guta, Gothones, Guthones, and Gothini, p. rogd. Dani, Suethans, and Suethidi, not necessarily Gothic, p. Iogd. Angli and Suevi; their location, p. Iogd. Regnar Loabrog in English History, A.D. 870 ; his speech understood, p. Iogd. Deficiency of the Collection of the Mon. Hist. Brit., as to early evidences of the English races, p. logd.

\section{AGRICULTURAL STATISTICS.}

\section{CHAPTER III (pp. roge-I6I).}

Tacitus' Germania, p. roge. Angli and Suevi, p. rogi. Early notices of Scandinavia, p. rogi. Scandinavian English, p. Iogi. The Angli and Suiones of Suevia; Dani, Dacians, and Guto, p. Iogj. Brittia and the Varni in the 6th century, p. Iogj. Traditional kinship of Angles, Danes, Jutes, Northmen, Saxons, and Suevi, p. Iogj. I 20 fiscal Acres, p. I1o. Walter de Henley's perpetual aration, p. III. Welsh evidence, $t$. Hen. II, p. III. Contrast of Agriculture, I086, I6g6, and 1897 , p. I12. Average yield of wheat per acre: neither evidence, nor probability in placing it at 6 bushels, p. Ir6. Agricultural data, ro86, p. I17. Consumption of beer, p. I17. Consumption of bread stuffs, etc., p. I 8 . Population of 1696 treble that of 1086, p. I18. Terra dupliciter ad arandum, p. I19. Meadow, 1086, p. II9. Poll Tax Returns of 1377 and 1379, p. 120. The Black Death, p. 121. Ploughs and Population, 1086, p. I21. Fallacy of figures in some counties, p. 122. Scheme of Inoo acres arable, I086, p. I23. Norfolk Carucates not Teamland̦, nor Hides ad gheldum, u t mainly areal estimates of arable land, p. 124. Proof 
of above statement, p. I25. Leuga, p. 126. Ripon Mile Crosses, p. 126. Liberty of Ripon, p. 126. How estimated in D. B., p. 127. Yorkshire Manors, p. 128. Examples therefrom, p. I29. 64 acres to I team in D. B., p. I30. Ely Manors, p. r30. Middlesex Villeins and their holdings, ro86, p. I3r. Peterboro' Villeins and their teams, II25-8, p. I3I. Population varies as ploughs, p. 132. Collation of Peterboro' Manors, 1125.8, with $D$. B., p. 133. Eccentric views of philosophers, p. 133. Examination of their methods, p. I34. Utility of same, p. 135. Manor of Alwalton, IIth, I2th, and r3th centuries, p. 135. Manor of Histon, 1086-1278, p. 137. Hundred Rolls, p. I38. Manor of Coatham, 1086-1279, p. 139. Genius of the Romantic School, p. 139. Fiscal Hides do not always denote Arable Land, p. 139. Marshland Hides, p. I40. Values of Arable, 1086, p. 140. Other Manorial Examples, p. I4I. Bedfordshire Carucates, p. I4I. Proof that demesne carucates were not usually tilled by one team, p. I42. Ramsey Manors, p. 143. Assistance of Customary tenants, p. I43. Lease of Hexham demesne, I232, p. I44. Lease of Le Blakelound, I292, p. I4.4. Manor of Harewood, 47 Hen. III, p. 144. Rochester Carucates, p. 145. Proportion of Teams in demesne, 1086, p. I45. Estimate of Eng. land, 1086, in the Village Community, p. I46. In some respects unreliable, p. I 46.8 oxen the standard Plough Team of Domesday, p. 146. Bordars often have plough oxen in D. B., p. 147. Method of 9 Counties Table, p. 447 . Illustra. tions of Villani, p. I48. Yorkshire Agriculture from the 1297 Subsidy Rolls, p. 149. Manor of Wilburton, p. 150. Its details refute college theories of Agriculture, p. 151. Great in. crease of ploughs in villeinage, p. 152. Rochester Manors, Io86, and $c$. Ed. I, p. 152. Plough services due therefrom, at latter period, p. I52. Agricultural details of the 12 th and $\mathrm{I}_{3}$ th centuries, p. 153. Demesne ploughmen's diverse duties, p. I55. Impracticability of current views of mediæval Agriculture, p. 156. Manor of Cuxham, p. I57. Manor of Cotum, p. 157. Manor of Quaringdon, p. 158. Manor of Adulfsnasa, p. 158. Rainfall, p. 158 . Mediæval agricultural measures, p. 158. 
FORTY-THREE TABLES

CHRONOLOGICALLY ARRANGED.

\begin{tabular}{|c|c|c|c|}
\hline Dates. & $\begin{array}{l}\text { Ref. } \\
\text { Nos. }\end{array}$ & Subject Matter. & Pages. \\
\hline Heptarchy. & A & Partial Hidage of Heptarchic & 08 \\
\hline 1065 & B & ClaroWapentake, Yorks; Status & 20 \\
\hline & C & $\begin{array}{l}\text { of some A.S. landowners, ... } \\
\text { ClaroWapentake,Yorks; Values }\end{array}$ & 30 \\
\hline $\left.\begin{array}{c}1065 \text { to } \\
20 E d . I I I\end{array}\right\}$ & & $\begin{array}{l}1065 \text { and } 1085 ; \text { Service } 3 \mathrm{I} \\
\text { Ed. I, and } 20 \text { Ed. III, }\end{array}$ & 45 \\
\hline 1086 & $\mathrm{D}$ & $\begin{array}{l}\text { Domesday Book; recorded Num- } \\
\text { ber, and Percentage of more }\end{array}$ & $4 J$ \\
\hline$"$ & $\mathrm{E}$ & $\begin{array}{c}\text { important Classes, ... } \\
\text { Domesday Book; County Con- } \\
\text { stitution Table, }\end{array}$ & 2 \\
\hline " & F & $\begin{array}{c}\text { Domesday Book; Main Statis- } \\
\text { tical Table, ... }\end{array}$ & \\
\hline " & G & $\begin{array}{ccc}\text { Domesday Book; } & \text { Table of } \\
\text { "Measures,"... } & \ldots & \ldots\end{array}$ & 5 \\
\hline$"$ & $\mathrm{H}$ & $\begin{array}{c}\text { Domesday Book; Comparative } \\
\text { Table } I, \quad \ldots\end{array}$ & $14-15$ \\
\hline " & I & $\begin{array}{c}\text { Domesday Book; Comparative } \\
\text { Table II, }\end{array}$ & \\
\hline " & $\mathrm{J}$ & $\begin{array}{c}\text { Domesday Book; Comparative } \\
\text { Table III, } \ldots\end{array}$ & \\
\hline ", & $\mathrm{K}$ & $\begin{array}{c}\text { Domesday Book; Arable of } \\
\text { England }(F \text {. Seebohm }),\end{array}$ & 146 \\
\hline ", & $\mathrm{L}$ & $\begin{array}{l}\text { Domesday Book; Proportion of } \\
\text { Lords' and Tenants' Teams }\end{array}$ & \\
\hline ", & M & $\begin{array}{l}\text { Estimate of Constitution, and } \\
\text { Population of Estate, with }\end{array}$ & 14 \\
\hline " & $\mathrm{N}$ & $\begin{array}{l}\text { Iooo acres Arab!e, ... } \\
\text { Domesday Book; Teams and } \\
\text { Teamlands of Yorkshire } \\
\text { Manors of given dimensions }\end{array}$ & 123 \\
\hline $1086-1125$ & $\mathrm{O}$ & $\begin{array}{c}(\text { Leugc }) \\
\text { Domesday Book }\end{array}$; collated with & 129 \\
\hline & & $\begin{array}{lccc}\text { Inquest of } & \text { some } & \text { Peterboro' } \\
\text { Manors, } & \ldots & \ldots & \ldots\end{array}$ & 133 \\
\hline
\end{tabular}


Forty-Three Tables Chronologically Arranged-contd.

\begin{tabular}{|c|c|c|c|}
\hline Dates. & $\begin{array}{l}\text { Ref. } \\
\text { Nos. }\end{array}$ & Subject Matter. & Pages. \\
\hline $\begin{array}{l}1086 \text { to } \\
\text { Hen. II }\end{array}$ & $\mathrm{P}$ & $\begin{array}{l}\text { Domesday Book; Carucates in } \\
\text { Fees of Earl Richmond and } \\
\text { Baron Perci ; also "Ser- } \\
\text { vice" ... }\end{array}$ & \\
\hline $1086-1279$ & Q & $\begin{array}{l}\text { Domesday Book and Hundred } \\
\text { Rolls; Manor of Histon, ... }\end{array}$ & $137 \cdot 8$ \\
\hline $\begin{array}{l}1086 \text { to } \\
\text { c. Ed.I }\end{array}$ & $\mathbf{R}$ & $\begin{array}{r}\text { Domesday Book; Demesne and } \\
\text { Villeinage Teams in some } \\
\text { Rochester Manors ; also } \\
1290-1320, \ldots\end{array}$ & \\
\hline $1086-E d .2$ & S & $\begin{array}{r}\text { Domesday Book; Hidage of } \\
\text { Ramsey Abbey Manors col- } \\
\text { lated with returns of } E d . I I\end{array}$ & ${ }^{152}$ \\
\hline $1086-1897$ & $\mathrm{~T}$ & $\begin{array}{l}\text { Domesday Book; Teamlands } \\
\text { and Crops (27 counties) esti- } \\
\text { mated against } 7897,\end{array}$ & $\mathrm{II}_{4}$ \\
\hline 1125.8 & U & $\begin{array}{r}\text { Constitution of some Peterboro' } \\
\text { Manors, and Acres tilled in } \\
\text { same, per Villein Team }(8 \\
\text { oxen), ... } \quad . .\end{array}$ & 132 \\
\hline $\begin{array}{l}\text { Hen. I to } \\
\text { Hen. VI }\end{array}$ & V & Records of Knight Service, ... & 77 \\
\hline $1166-8$ & w & Analysis of Ecclesiastical Fees, & 62 \\
\hline$"$ & $\mathrm{x}$ & Summary of "Service," & 64 \\
\hline$"$ & $\mathrm{Y}$ & $" \quad$ "Total Fees, & 65 \\
\hline " & $Z$ & $\begin{array}{c}\text { Analysis of } 5 \text { I } \\
\text { "Service," }\end{array}$ & 55 \\
\hline " & AA & $\begin{array}{c}\text { Analysis of } 76 \text { cases of unknown } \\
\text { "Service," }\end{array}$ & 5.5 \\
\hline$"$ & BB & Analysis of New Feoffment, ... & $6 I$ \\
\hline$"$ & $\mathrm{CC}$ & General Examples Tabulated,... & 66 \\
\hline " & DD & Exceptional Cases, & 57 \\
\hline, & EE & Fees due, not charged, ... & 6I \\
\hline
\end{tabular}


Forty.Three Tables Chronologically Arranged-contd.

\begin{tabular}{|c|c|c|c|}
\hline Dates. & $\begin{array}{l}\text { Ref. } \\
\text { Nos }\end{array}$ & Subject Matter. & Pages. \\
\hline $1166-1346$ & FF & $\begin{array}{c}\text { Knight Service ; } 5 \text { Tables } t \\
\text { Hen. } I I, \text { Fohn, Hen. III, } \\
\text { Ed. I, and Ed.III, .. } \quad \ldots\end{array}$ & 50 \\
\hline $\left.\begin{array}{c}\text { Hen. II to } \\
\text { Ed.III }\end{array}\right\}$ & GG & $\begin{array}{l}\text { Tabular Illustrations of Feudal } \\
\text { Service, from Madox, etc.,... }\end{array}$ & $90-92$ \\
\hline $\begin{array}{l}\text { Foln to } \\
\text { Ed. III }\end{array}$ & $\mathrm{HH}$ & $\begin{array}{c}\text { Tabular Illustrations of Abbot } \\
\text { of Peterboro's Service, }\end{array}$ & $84-85$ \\
\hline Hen. III to & II & Carucates and Fees-examples & \\
\hline Hen. VI & & $\begin{array}{lllll}\text { of }, & \cdots & \cdots & \cdots & \cdots\end{array}$ & $77-78$ \\
\hline 1242 & $\mathrm{JJ}$ & $\begin{array}{c}\text { Examples of Fines for Army of } \\
\text { Gascony, }\end{array}$ & 74 \\
\hline $\begin{array}{c}29 \text { Hen. III } \\
\text { to Ric. II }\end{array}$ & $\mathrm{KK}$ & $\begin{array}{l}\text { Tabular Illustrations of } \ddot{F} \text { eudal } \\
\text { Service, mainly from } u n \text { - } \\
\text { printed MSS }\end{array}$ & 14 \\
\hline $1251-1279$ & LL & $\begin{array}{r}\text { Ramsey Manors - correspond. } \\
\text { ence of Demesne Ploughs, } \\
\text { with Demesne Carucates, ... }\end{array}$ & 142 \\
\hline t. Hen. III & $\mathrm{MM}$ & Table of Perpetual Aration, ... & I I I \\
\hline 1278.9 & $\mathrm{NN}$ & $\begin{array}{c}\text { Agricultural Analysis of Manor } \\
\text { of Alwalton, ... }\end{array}$ & 136 \\
\hline t. Ed.I & OO & $\begin{array}{l}\text { Bedfordshire Demesne Caru- } \\
\text { cates-average acreage of }\end{array}$ & \\
\hline 1379 & PP & $\begin{array}{l}\text { Claro Wapentake, Yorks; com- } \\
\text { position of Population per } \\
\text { I000, over } 16 \text { years of age }\end{array}$ & 141 \\
\hline $1696-1897$ & QQ & $\begin{array}{ccc}(\text { Poll } T a x) & \ldots & \ldots \\
\text { Agricultural Statistics } & \text { of } & \text { Eng. } \\
\text { land and Wales, } & \ldots & \ldots\end{array}$ & 120 \\
\hline
\end{tabular}


THE ABOVE FORTY-THREE

TABLES ARRANGED BY SUBJECT MATTER.

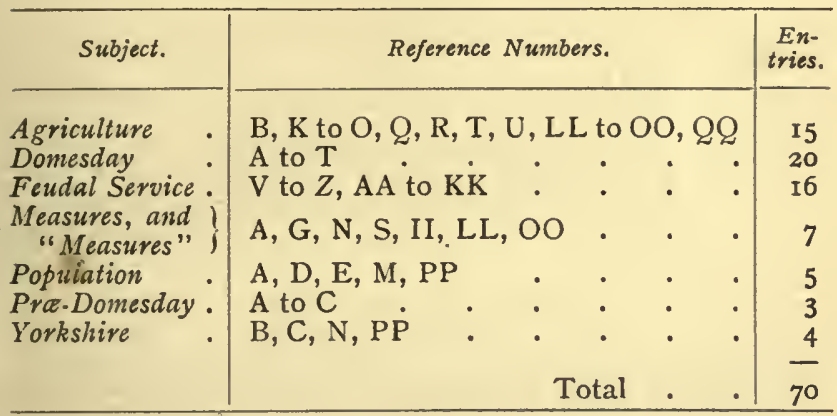

STATISTICAL INDEX OF TEXT, ARRANGED CHRONOLOGICALLY AND BY SUBJECTS, BUT NOT INCLUDING DETAILS OF ABOVE FORTY-THREE TABLES-194 REFERENCES

AGRICULTURE (Nos. 1-30).

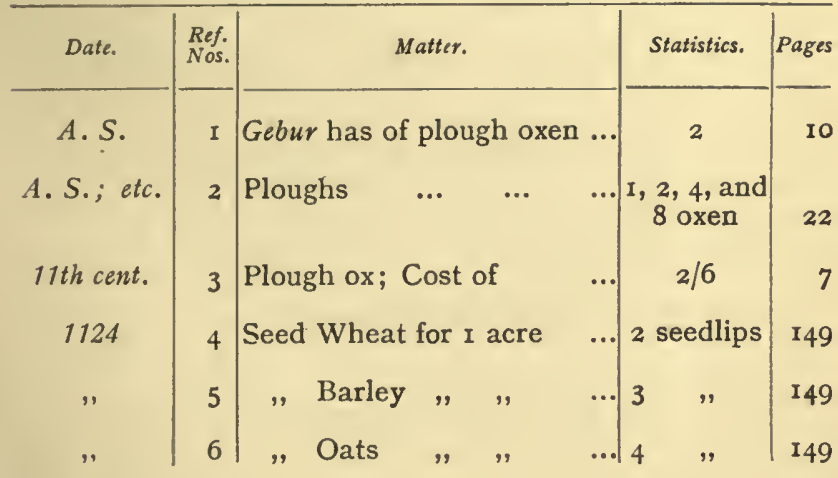




\section{STATISTICAL INDEX OF TEXT-contd.}

Agriculture (Nos. 1-30)-contd.

\begin{tabular}{|c|c|c|c|c|}
\hline Date. & $\begin{array}{l}\text { Ref. } \\
\text { Nos. }\end{array}$ & Matter. & Statistics. & Pages \\
\hline $1125-8$ & 7 & $\begin{array}{l}\text { A verage acres tilled by villein } \\
\text { team (including work on } \\
\text { demesne), Peterboro' Man- } \\
\text { ors }\end{array}$ & 64 & 132 \\
\hline $\begin{array}{l}12 \text { th E } \\
\text { cent. }\end{array}$ & 8 & $\begin{array}{l}\text { Villeins, Bordars, Cottars; } \\
\text { Holdings of }\end{array}$ & $\begin{array}{c}3 \text { acres to } \\
\text { I virgate }\end{array}$ & 1 \\
\hline $\begin{array}{l}\text { 12th to } 13 \text { th } \\
\text { cent. }\end{array}$ & 9 & $\begin{array}{l}\text { Each virgate in villeinage } \\
\text { averages at least }\end{array}$ & $4 \underset{\text { oxen }}{4 \text { plough }}$ & $\begin{array}{r}153, \\
154\end{array}$ \\
\hline t. Hen. II & ro & Welsh Ploughs & $\begin{array}{r}\text { usua } \\
\text { ox }\end{array}$ & 18 \\
\hline 1221 & II & $\begin{array}{c}\text { Northants-part of; } \\
\text { teams in (see No. } 7 \mathrm{r})\end{array}$ & $2613 \frac{1}{4}$ & 3. \\
\hline 1222 & 12 & $\begin{array}{c}720 \text { arable demesne acres, } \\
\text { explanation of why only }\end{array}$ & 3 te & 15 \\
\hline $1235-1$ & I3 & $\begin{array}{cccc}\text { Carucarii often hold in vil } \\
\text { leinage } & \ldots & \ldots & \ldots\end{array} \mid$ & $3-5$ acres & \begin{tabular}{l|l}
$\mathrm{s}$ & 155
\end{tabular} \\
\hline t. Hen. III & I4 & $\begin{array}{l}\text { Yield of wheat, per sown } \\
\text { acre }\end{array}$ & $\begin{array}{l}\text { Io to } \\
\text { bust }\end{array}$ & II 6 \\
\hline$"$ & I5 & $\begin{array}{c}\text { Allowance of corn of farm } \\
\text { servant per } 12 \text { weeks }\end{array}$ & I quàrter & I I \\
\hline t. Ed.I & I6 & $\begin{array}{l}\text { Areal Hide in Hundred } \\
\text { Rolls }\end{array}$ & $\begin{array}{c}\text { I } 20 \text { acres, } \\
\text { etc. }\end{array}$ & $3^{2}$ \\
\hline 1279 & I7 & $54^{8}$ demesne acres, tilled by & $\begin{array}{c}8 \text { or } \\
8+\text { teams }\end{array}$ & s 14 \\
\hline 1333.5 & 18 & Yield of grain per sown acre & $\begin{array}{l}\text { Io to } \\
\text { bush }\end{array}$ & \\
\hline
\end{tabular}


STATISTICAL INDEX OF TEXT-contd.

Agriculture (Nos. 1-30)-contd.

\begin{tabular}{|c|c|c|c|c|}
\hline Date. & $\begin{array}{l}\text { Ref. } \\
\text { Nos. }\end{array}$ & Matter. & Statistics. & Pages \\
\hline 14th cent. & 19 & Cost of plough implement & $\mathrm{I} / \mathrm{F}$ & \\
\hline$"$ & 20 & $" \quad, \quad, \quad$ ox $\quad \ldots$ & $15 /$. & \\
\hline t. Elizabeth & $2 \mathrm{I}$ & Ploughland; Acres in & 60 & II \\
\hline 1696 & 22 & $\begin{array}{c}\text { Arable acres in rotation: } \\
\text { England and Wales }\end{array}$ & $10,000,000$ & II 3 \\
\hline , & 23 & Of total arable; sown acres & $\frac{2}{3}$ or $\frac{2}{3}+$ & $\begin{array}{l}115, \\
116\end{array}$ \\
\hline " & 24 & $\begin{array}{l}\text { Pasture and meadow: Eng- } \\
\text { land and Wales }\end{array}$ & $\begin{array}{c}\text { Io,ooo,ooo } \\
\text { acres }\end{array}$ & \\
\hline " & 25 & $\begin{array}{l}\text { Yield of Grain: England } \\
\text { and Wales }\end{array}$ & $\begin{array}{c}90,000,000 \\
\text { bushels }\end{array}$ & 115 \\
\hline$"$ & 26 & Yield of Grain per sown acre & $\begin{array}{l}\text { I3 to I } 4 \\
\text { bushels }\end{array}$ & $\begin{array}{l}\mathrm{II}_{5}, \\
\mathrm{II} 8\end{array}$ \\
\hline$"$ & 27 & $\begin{array}{cccc}\text { Grain food of man } & \text { per head } \\
\text { from } & \cdots & \cdots & \cdots\end{array}$ & $\frac{9}{20}$ acre & II 8 \\
\hline$"$ & 28 & $\begin{array}{l}\text { Barley malted in England } \\
\text { and Wales }\end{array}$ & $\begin{array}{c}2 \text { I } \frac{1}{2} \text { million } \\
\text { bushels }\end{array}$ & 117 \\
\hline " & 29 & ead raised from & cre & $x \times 7$ \\
\hline$"$ & 30 & $\begin{array}{l}\text { Beer daily per head... } \\
\text { See also: Nos. } 47 \text { to } 57 ; 64 \text { to } \\
80 ; \text { I66 to } 178 ; \text { and } 180 .\end{array}$ & $1 \frac{3}{4}$ pints & II \\
\hline
\end{tabular}


xxiv Domesday and Feudal Statistics

STATISTICAL INDEX OF TEXT-contd.

DOMESDAY (Nos. 31-80).

\begin{tabular}{|c|c|c|c|c|}
\hline Date. & $\begin{array}{l}\text { Ref. } \\
\text { Nos. }\end{array}$ & Matter. & Statistics. & Pages \\
\hline c. 1065 & $3 I$ & $\begin{array}{l}\text { Liberi Homines, Sokemen, } \\
\text { Homines, Fratres, Thanes, } \\
\text { Burgesses, and Radknights } \\
\text { (Ellis) }\end{array}$ & $\begin{array}{l}6,000 \text { to } \\
7,000\end{array}$ & 30 \\
\hline$"$ & 32 & $\begin{array}{l}\text { A.S. Landowners, excluding } \\
\text { Liberi Homines, and Soke- }\end{array}$ & & \\
\hline & & $\operatorname{men} \quad \ldots \quad \ldots$ & c. 13,000 & 30 \\
\hline $1065 \cdot 1086$ & 33 & Landowners A. S. to A. N. & $3: 2$ & 30 \\
\hline 1086 & 34 & Recorded Population & 283,242 & 2 \\
\hline " & 35 & to all England $\quad \ldots \quad$ extended & c. 300,000 & II 7 \\
\hline$"$ & 36 & $\begin{array}{l}\text { Villeins, bordars, cottars } \\
\text { and cosce } z \text {, servi; of total } \\
\text { population }\end{array}$ & $\frac{4}{5}$ & I \\
\hline$"$ & 37 & Total population (England) & I $, 800,000$ & 5 \\
\hline$"$ & $3^{8}$ & " capital tenants & c. $I, 400$ & 68 \\
\hline$"$ & 39 & $\begin{array}{l}\text { Tenants in capite, and Mesne } \\
\text { Lords }\end{array}$ & $\begin{array}{l}9,000 \text { to } \\
10,000\end{array}$ & $\begin{array}{l}30, \\
102\end{array}$ \\
\hline$"$ & 40 & $\begin{array}{l}\text { Church lands; Value of (in } \\
2 \text { I counties) to total }\end{array}$ & $\frac{3}{10}$ & 63 \\
\hline " & $4^{I}$ & $\begin{array}{l}\text { Hides in } D . B \text {. in } 34 \text { coun- } \\
\text { ties (as from Prof. Maitland) }\end{array}$ & c. 67,000 & 35 \\
\hline ", & 42 & Places-Number of... & $\begin{array}{l}\text { I } 5,000 \text { to } \\
\text { I } 8,000\end{array}$ & $3 I$ \\
\hline$"$ & 43 & Population per place & c. 100 & $3 I$ \\
\hline$"$ & 44 & Counties in $D . B$. ... & 34 & I \\
\hline
\end{tabular}


STATISTICAL INDEX OF TEXT-contd.

Domesday (Nos. 31-80)-contd.

\begin{tabular}{|c|c|c|c|c|}
\hline Date. & $\begin{array}{l}\text { Ref. } \\
\text { Nos. }\end{array}$ & Matter. & Statistics. & Yages \\
\hline 1086 & 45 & Milites (Ellis) & 137 & 102 \\
\hline$"$ & 46 & " (actually found) & $700+$ & 103 \\
\hline " & 47 & Villeins-their holdings & $\left|\begin{array}{l}n i l, 7 \text { acres } \\
\text { to } 2 \text { Hides }\end{array}\right|$ & 10 \\
\hline$"$ & 48 & $\begin{array}{l}\text { some at Hanwell and } \\
\text { West Bedfont }\end{array}$ & $\begin{array}{l}2 \text { fiscal } \\
\text { Hides }\end{array}$ & $\begin{array}{l}10, \\
131\end{array}$ \\
\hline$"$ & 49 & $\begin{array}{l}\text { Villeins_average holdings } \\
\text { Middlesex }\end{array}$ & $\begin{array}{l}\text { I fiscal } \\
\text { virgate }\end{array}$ & 10 \\
\hline " & 50 & $\begin{array}{c}\text { Villeins-Cambridge, in Ely } \\
\text { Manors } \ldots\end{array}$ & Io $\frac{1}{2}$ acres & 10 \\
\hline$"$ & $5 \mathrm{I}$ & $\begin{array}{l}\text { Villeins-average holdings } \\
\text { England (estimated) }\end{array}$ & $\begin{array}{c}20 \text { to } 21 \\
\text { acres }\end{array}$ & II \\
\hline ", & 52 & Villeins-plough oxen & $\begin{array}{c}\text { nil to } 3 \frac{1}{2} \\
\text { teams to } 3 \\
\text { villeins }\end{array}$ & 148 \\
\hline$"$ & 53 & $\begin{array}{l}\text { Villeins - average plough } \\
\text { oxen not less than }\end{array}$ & 2 & $\begin{array}{l}13 . \\
122\end{array}$ \\
\hline$"$ & 54 & Bordars-holdings ... & $\begin{array}{l}\text { nil to } 2 \\
\text { bovates }\end{array}$ & II \\
\hline$"$ & 55 & " plough oxen & $\begin{array}{l}\text { mil to } 8 \\
\text { oxen }\end{array}$ & II \\
\hline ", & 56 & Coscez, $\quad, \quad " \ldots$ & $\begin{array}{l}\text { mil to } 4 \\
\text { oxen }\end{array}$ & 11 \\
\hline " & 57 & Cottars, $\quad, \quad, \ldots$ & $\left|\begin{array}{c}\text { nil to } 6 \\
\text { cottars per } \\
\text { team } \\
\text { (8 oxen). }\end{array}\right|$ & \\
\hline
\end{tabular}


xxvi Domesday and Feudal Statistics

STATISTICAL INDEX OF TEXT—contd.

Domesday (Nos.31-80)-contd.

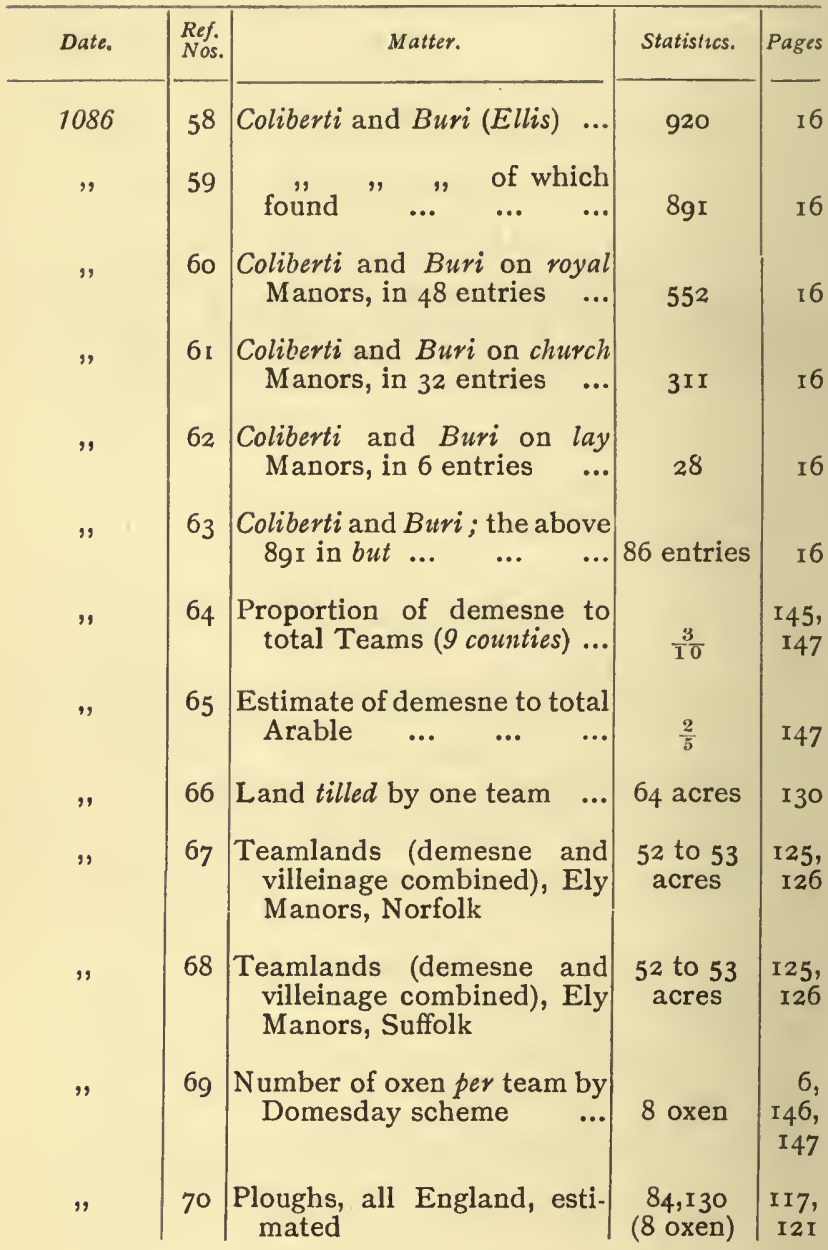




\section{STATISTICAL INDEX OF TEXT—contd.}

Domesday (Nos. 31-80)-contd.

\begin{tabular}{|c|c|c|c|c|}
\hline Date. & $\begin{array}{l}\text { Ref. } \\
\text { Nos. }\end{array}$ & Matter. & Statistics. & Pages \\
\hline 1086 & 71 & $\begin{array}{l}\text { Ploughs in co. Northants (see } \\
\text { No. I I) }\end{array}$ & $\begin{array}{c}2,422 \\
(8 \text { oxen })\end{array}$ & 33 \\
\hline " & 72 & $\begin{array}{c}\text { Examples of one to sevenoxen, } \\
\text { I team, and nine to ten oxen } \\
\text { in } D . B ., \text { but not of }\end{array}$ & 8 oxen & $\begin{array}{l}146, \\
147\end{array}$ \\
\hline$"$ & 73 & $\begin{array}{l}\text { Ploughs ( } 8 \text { oxen each, } D . B \text {.) } \\
\text { in the } 34 \text { recorded coun- } \\
\text { ties }\end{array}$ & c. 78,000 & $\begin{array}{r}121 \\
122, \\
146\end{array}$ \\
\hline$"$ & 74 & $\begin{array}{l}\text { Ploughs ( } 8 \text { oxen each, D. B.) } \\
\text { in } 30 \text { counties }\end{array}$ & 70,606 & $\begin{array}{r}4, \\
117\end{array}$ \\
\hline ", & 75 & $\begin{array}{l}\text { rooo acres arable supports } \\
\text { of recorded population }\end{array}$ & $47+$ & $\begin{array}{r}123 \\
124\end{array}$ \\
\hline ", & 76 & Iooo acres arable tilled by & $\begin{array}{c}\text { c. } 16 \text { teams } \\
\text { (8 oxen } \\
\text { each) }\end{array}$ & 123 \\
\hline ", & 77 & $\begin{array}{cccc}\text { I } \begin{array}{ccc}\text { acre arable, } \\
\text { value }\end{array} & \ldots & \ldots & \ldots\end{array}$ & $2 \mathrm{~d}$. & 140 \\
\hline $\left.\begin{array}{l}\text { Wm. I to } \\
\text { Ed.I or } \\
\text { Ed.II. }\end{array}\right\}$ & 78 & \begin{tabular}{ccrr} 
Some Rochester & \multicolumn{2}{c}{ Manors; } \\
Teams, latter to former \\
period & $\ldots$ & $\ldots$ & $\ldots$
\end{tabular} & $2: 1$ & 152 \\
\hline$"$ & 79 & $\begin{array}{ccc}\text { Some Rochester } & \text { Manors; } \\
\text { demesne Teams, latter to } \\
\text { former period } & \ldots & \ldots\end{array}$ & I : I & 152 \\
\hline$"$ & 80 & $\begin{array}{c}\begin{array}{c}\text { Some Rochester Manors; } \\
\text { villeinage Teams, latter to } \\
\text { former period } \ldots\end{array} \\
\begin{array}{c}\text { See also: Nos. I to } 2 ; 82 ; 84 \\
\text { to } 87 ; 162 \text { to } 165 ; 181 \text { to } \\
184 ; \text { and } 192 .\end{array}\end{array}$ & $9: 4$ & 152 \\
\hline
\end{tabular}




\section{xxviii Domesday and Feudal Statistics}

STATISTICAL INDEX OF TEXT-contd.

FEUDAL SERVICE (Nos. 81-161).

\begin{tabular}{|c|c|c|c|c|}
\hline Date. & $\begin{array}{l}\text { Ref. } \\
\text { Nos. }\end{array}$ & Matter. & Statistics. & Pages \\
\hline $996-1026$ & $8 I$ & $\begin{array}{l}\text { Military service (cited by } \mathcal{F} . \\
\text { F. Baldwin) }\end{array}$ & $\begin{array}{l}\text { mil } \\
\text { stat }\end{array}$ & 109 \\
\hline t. Wm. I & 82 & $\begin{array}{l}\text { Possible reference to escuage } \\
\text { or its antecessor, before }\end{array}$ & A.D. 1086 & $8 \mathrm{I}$ \\
\hline " & 83 & $\begin{array}{l}\text { Dean of Evreux, bent with } \\
\text { age (1066-89), holds of } \\
\text { paternal inheritance }\end{array}$ & $\underset{\text { fee }}{\text { I knight's }}$ & IO4 \\
\hline 1086 & 84 & $\begin{array}{c}\text { Total capital tenants by } \\
\text { knight service (ut de } \\
\text { corona), probably ... }\end{array}$ & 300 & 68 \\
\hline $1086 \cdot 1166$ & 85 & $\begin{array}{c}\text { Knights' Fees, in the } D . B . \\
\text { Hides of Prof. Maitland }\end{array}$ & c. 50,000 & 79 \\
\hline $\left.\begin{array}{c}1086- \\
12 \text { Car. II }\end{array}\right\}$ & 86 & Value of Knight's Fee & $\begin{array}{l}£^{2} \text { to } £ 200 \\
\text { p. a. }\end{array}$ & 45 \\
\hline t. Wm. I & 87 & $\begin{array}{l}\text { John holds Teusham of the } \\
\text { Abbot of Ely, as }\end{array}$ & $\begin{array}{c}2 \text { knight's } \\
\text { fees }\end{array}$ & 109 \\
\hline 1088 & 88 & $\begin{array}{l}\text { The Bishop of Durham has } \\
\text { (not necessarily all feudal } \\
\text { tenants) as retainers }\end{array}$ & roo milites & 42 \\
\hline 1103 & 89 & $\begin{array}{l}\text { Earl Flanders' service to the } \\
\text { King of France ... }\end{array}$ & Io knights & 107 \\
\hline 1109 & 90 & $\begin{array}{l}\text { Aid to marry the daughter } \\
\text { of Hen.I }\end{array}$ & $\begin{array}{l}\text { 3/- per } \\
\text { Hide }\end{array}$ & 83 \\
\hline Hen. $I-I I$ & $9^{I}$ & $\begin{array}{l}\text { Flemish Knights for Eng- } \\
\text { land }\end{array}$ & $\begin{array}{l}500 \text { and } \\
1000\end{array}$ & $100 \alpha$ \\
\hline$"$ & 92 & Horses per Knight ... & 3 & $100 a$ \\
\hline $1107-8$ & 93 & $\begin{array}{ccc}\text { Bigot Roger (ob. } & 1107 & \text { or } \\
1108) \text { had feft in } & \ldots & \ldots\end{array} \mid$ & I 5 fees & $\begin{array}{r}108 \\
109\end{array}$ \\
\hline
\end{tabular}


STATISTICAL INDEX OF TEXT-centd

Feudal Service (Nos. 81-161)-contd.

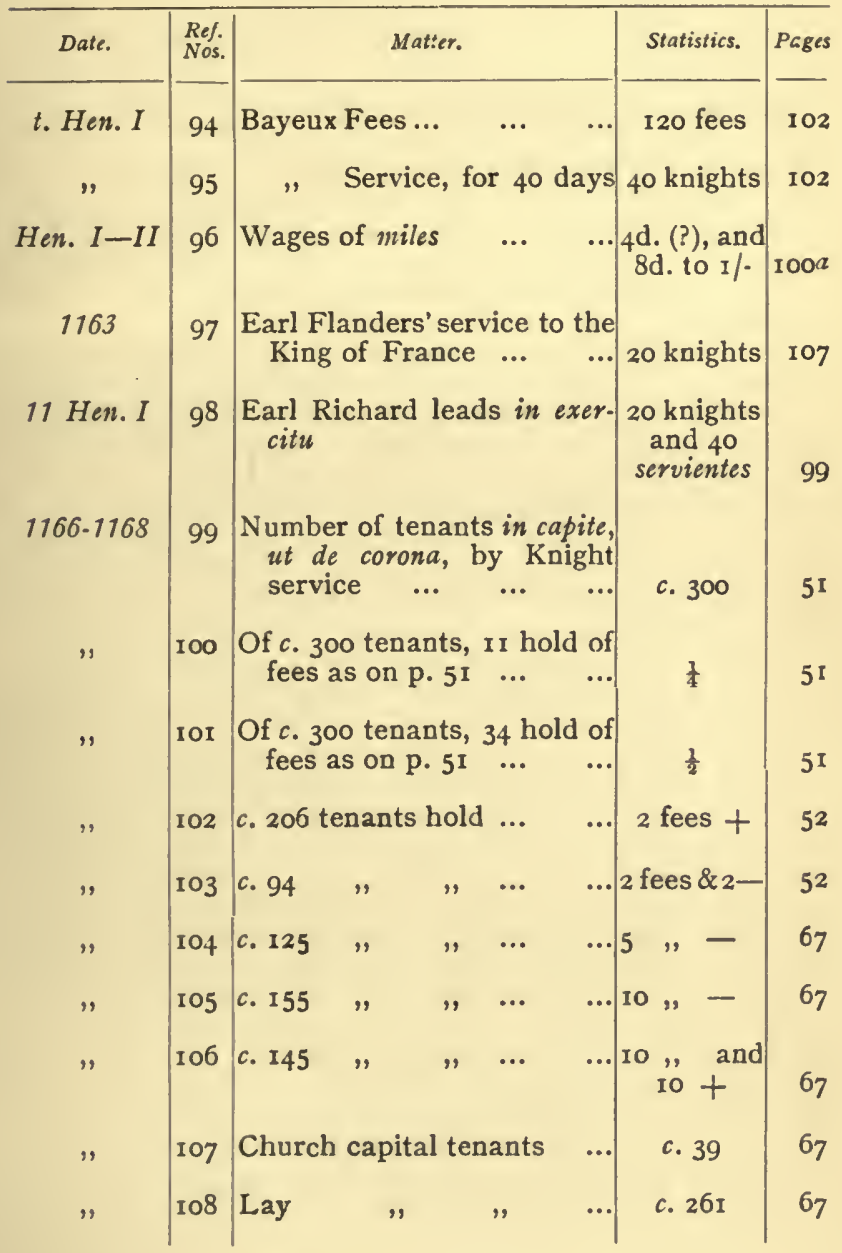


STATISTICAL INDEX OF TEXT-contd.

Feudal Service (Nos. 81-161)-contd.

\begin{tabular}{|c|c|c|c|c|}
\hline Date. & $\begin{array}{l}\text { Ref. } \\
\text { Nos }\end{array}$ & Matter. & Statistics. & Pages \\
\hline $1166 \cdot 1168$ & 109 & Total Fees, England & $7173+$ & 65 \\
\hline ", & I Io & Old feoffment, as given & 4903 fees & 65 \\
\hline$"$ & I I I & New " & $483 \quad$, & 65 \\
\hline " & 112 & Returas by sheriff, as given & 745, & 65 \\
\hline$"$ & 113 & Super dominicum, , & $315 \frac{1}{2}$, & 65 \\
\hline$"$ & 114 & $\begin{array}{c}\text { Deficiency, not returued, } \\
\text { estimated at }\end{array}$ & $\begin{array}{c}700 \text { to } 800 \\
\text { fees }\end{array}$ & 54 \\
\hline$"$ & II 5 & $\begin{array}{c}\text { Total "Service," } \\
\text { estimated ... }\end{array}$ & $6676+$ & 64 \\
\hline " & II 6 & Estimate of Fees (Pearson) & 6400 & 53 \\
\hline$"$ & I1 7 & $\begin{array}{ccc}\text { Number of } & \text { Fees, of "Ser. } \\
\text { vices" of more than } & 100 \\
\text { Knights } & \ldots & \ldots\end{array}$ & II cases & 99 \\
\hline " & เ 18 & Average Lay Fee $\ldots$ & $\begin{array}{c}5 \text { to } 6 \\
D . B . \text { Hides }\end{array}$ & 43 \\
\hline ", & II9 & Scope of Church Fee & $\begin{array}{l}12,000 \\
\text { acres }\end{array}$ & 65 \\
\hline " & 120 & $\begin{array}{ccc}\text { Church fees to total, as by } \\
\text { service } & \ldots & \ldots\end{array}$ & $\frac{1}{6}$ to $\frac{1}{7}$ & 63 \\
\hline$"$ & $12 \mathrm{I}$ & Scope of Lay Fee ... & 2,500 acres & 65 \\
\hline " & 122 & Charters -names in & c. 4000 & 103 \\
\hline " & 123 & $\begin{array}{l}\text { names holding } \\
\text { less than I fee } \quad \ldots\end{array}$ & c. $\mathrm{I} 600$ & 103 \\
\hline
\end{tabular}


STATISTICAL INDEX OF TEXT-contd.

Feudal Service (Nos. 81-161)-contd.

\begin{tabular}{|c|c|c|c|c|}
\hline Date. & $\begin{array}{l}\text { Ref. } \\
\text { Nos. }\end{array}$ & Matter. & Statistics. & Pages \\
\hline $1166 \cdot 1168$ & 124 & $\begin{array}{l}36 \frac{3}{5} \text { fees of Simon de Beau- } \\
\text { champ (all of old feoff- } \\
\text { ment), held by } \ldots .\end{array}$ & 85 tenants & 103 \\
\hline " & 125 & Charters; "Service" stated & c. 146 cases & 57 \\
\hline " & 126 & 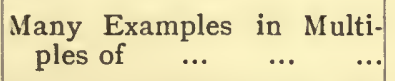 & 5 fees & 67 \\
\hline$"$ & 127 & $\begin{array}{c}\text { A meaningless phrase }- \text { feu } \\
\text { dal service of } \quad \ldots\end{array}$ & I ooo Hides & 46 \\
\hline ", & 128 & $\begin{array}{r}\text { Honor of Totnes consisted } \\
\text { of } 49+19 \frac{4}{15}+\frac{11}{15} \text {, that is }\end{array}$ & 75 fees & 55 \\
\hline t. Hen. II & I 29 & Normandy-no. of Fees ... & $\begin{array}{l}\text { I500, or } \\
\text { I830 }\end{array}$ & 102 \\
\hline , & 130 & $" \quad$-Service & 581 , or 652 & 102 \\
\hline$"$ & $13 I$ & Bayeux - & 20 knights & 102 \\
\hline " & 132 & Bayeux fees ... & c. 120 & 102 \\
\hline $\begin{array}{c}\text { Hen. } I I-। \\
I I I\end{array}$ & I33 & Fees of Bishop of Durham & $\begin{array}{c}\text { Io, } 70 \text { and } \\
\text { I50 }\end{array}$ & 43 \\
\hline $\begin{array}{l}\text { 7. Fohn to } \\
\text { t. Hen. III }\end{array}$ & 134 & $\begin{array}{l}\text { Variations of Fees as to } \\
\text { Hides and Carucates (see } \\
\left.\text { Nos. }{ }^{3} 6,150\right)\end{array}$ & $\begin{array}{c}2 \frac{1}{2} \text { to } 159 \\
\text { carucates } \\
\text { per fee }\end{array}$ & $\begin{array}{r}43, \\
44\end{array}$ \\
\hline 1211 & I35 & $\begin{array}{c}\text { Army of Ireland, greatest } \\
\text { number of knights of feu- } \\
\text { dal tenant ... }\end{array}$ & Io & I I I \\
\hline 1242 & I 36 & $\begin{array}{c}\text { Hides per fee, a case of (see } \\
\text { Nos. } 134,150)\end{array}$ & 32 & 75 \\
\hline
\end{tabular}


STATISTICAL INDEX OF TEXT-contd.

Feudal Service (Nos. 81-161)-contd.

\begin{tabular}{|c|c|c|c|c|}
\hline Date. & $\begin{array}{l}\text { Ref. } \\
\text { Nos. }\end{array}$ & Matter. & Statistics. & Pages \\
\hline 38 Hen. III & I 37 & $\begin{array}{r}\text { Number of capital tenants } \\
(u t \text { de corona), by Knight } \\
\text { Service (auxilium) }\end{array}$ & c. $45^{\circ}$ & $5 \mathrm{I}$ \\
\hline " & 138 & Fees omitted in above record & $775+$ & $5 I$ \\
\hline 38 Hen. III & I 39 & Total fees (rentder) ... & $6734+$ & $5^{I}$ \\
\hline$"$ & 140 & $\begin{array}{cccc}\text { Number of } & \text { Fees, of " } & \text { Ser- } \\
\text { vices" of } & \text { more than } & \text { Ioo } \\
\text { knights } & \ldots & \ldots & \ldots\end{array}$ & 9 cases & 99 \\
\hline , & 141 & $\begin{array}{r}\text { Of } 5959 \text { fees (returned) with } c . \\
439 \text { tenants in capite (ut de } \\
\text { corona) of all the fees, } 9 \\
\text { feudatories hold ... }\end{array}$ & $\frac{1}{4}$ & $5^{I}$ \\
\hline$"$ & 142 & $\begin{array}{r}\text { Of } 5959 \text { fees (returned) with } c . \\
439 \text { tenants in capite (ut de } \\
\text { corona) of all the fees, } 29 \\
\text { feudatories hold ... }\end{array}$ & $\frac{1}{2}$ & $5^{I}$ \\
\hline " & 143 & Re above, 204 tenants hold & 2 fees $t$ & $5^{\mathrm{r}}$ \\
\hline " & I 44 & $" \quad, \quad 235$ & 2 fees and & \\
\hline$"$ & I45 & $\begin{array}{l}\text { The Luterell fee (see Nos. I } 48 \text {, } \\
\text { I5i), assessed to an aux- } \\
\text { ilium at ... }\end{array}$ & I $2 \frac{1}{2}$ fees & $\begin{array}{r}89, \\
90\end{array}$ \\
\hline t. Hen. III & 146 & $\begin{array}{c}\text { Estimated number of } \\
\text { norets and Bachelors }\end{array}$ & $\begin{array}{l}\text { I000 to } \\
\text { I } 500\end{array}$ & 99 \\
\hline $\begin{array}{c}\text { Hen. } I I I-\} \\
\text { Ed. II }\end{array}$ & 147 & Period of service in exercitu & 40 days & 102 \\
\hline $5 E d . I$ & 148 & $\begin{array}{l}\text { The Luterell fee, discharged } \\
\text { by service in exercitu (see } \\
\text { also Nos. I 45: I5 } 1 \text { ) of } \ldots\end{array}$ & & 88 \\
\hline
\end{tabular}


STATISTICAL INDEX OF TEXT-contd.

Feudal Service (Nos. 81-161)-contd.

\begin{tabular}{|c|c|c|c|c|}
\hline Date. & $\begin{array}{l}\text { Ref. } \\
\text { Nos. }\end{array}$ & Matter. & Statistics. & Pages \\
\hline 1284 & 149 & $\begin{array}{l}\text { Pact with a miles for quit- } \\
\text { tance of service of I fee } \\
\text { (recognised in exercitu), in } \\
\text { the Welsh war, for }\end{array}$ & $£^{20}$ & 100 \\
\hline t. Ed.I & 150 & $\begin{array}{c}\text { Hides per fee, a case of (see } \\
\text { Nos. } 134,136)\end{array}$ & 2 & $7^{8}$ \\
\hline $10 \mathrm{Ed} . \mathrm{I}$ & I $5 \mathrm{I}$ & $\begin{array}{r}\text { The Luterell fee (see Nos. I } 45, \\
148) \text {, in default of service } \\
\text { in exercitu, and presumably } \\
\text { no fine having been taken, } \\
\text { pays Scutage, 35 years } \\
\text { after said army, on }\end{array}$ & I2 $\frac{1}{2}$ fees & 95 \\
\hline t. Ed. $I$ & 152 & $\begin{array}{l}\text { The Bishop of Durham has } \\
\text { in the Scotch war (not } \\
\text { necessarily as his service, } \\
\text { i.e. Io) }\end{array}$ & $\begin{array}{c}26 \mathrm{Ban} \\
\text { nerets, I40 } \\
\text { Knights }\end{array}$ & \\
\hline 1300 & 153 & $\begin{array}{c}\text { The same has at Caer- } \\
\text { laverock }\end{array}$ & 160 men at & 42 \\
\hline $4 E d . I I$ & 154 & $\begin{array}{l}\text { Expenses of I miles for the } \\
\text { Scotch war }\end{array}$ & $\begin{array}{c}60 \\
\operatorname{marcs}\end{array}$ & 100 \\
\hline 1346 & I 55 & $\begin{array}{cccc}\text { Fees found at this date } & (36 \\
\text { counties) } & \ldots & \ldots\end{array}$ & c. 6000 & 69 \\
\hline $20 \mathrm{Ed} . I I I$ & 156 & Fees in Cornwall $\ldots$ & $165^{\frac{3}{4}}$ & 70 \\
\hline$"$ & 157 & $\begin{array}{c}\text { English Earls, Bannerets, } \\
\text { and Knights, at Calais ... }\end{array}$ & c. 1063 & $9^{8}$ \\
\hline " & 158 & English Esquires, at Calais & c. 3000 & $9^{8}$ \\
\hline
\end{tabular}




\section{xxxiv Domesday and Feudal Statistics}

STATISTICAL INDEX OF TEXT-contd.

Feudal Service (Nos. 81-161)-contd.

\begin{tabular}{|c|c|c|c|c|}
\hline Date. & $\begin{array}{l}\text { Ref. } \\
\text { Nos. }\end{array}$ & Matter. & Statistics. & Pages \\
\hline 4 Hen. IV & I 59 & $\begin{array}{l}\text { Returns at } £ \text { I per fee of } \\
\text { tenants "in capite," by } \\
\text { Knight Service }(30 \text { coun- } \\
\text { ties), and of capital soca- } \\
\text { gers ( } £ 20 \text { land as for I fee) }\end{array}$ & $£ 1075$ & 70 \\
\hline ", & 160 & $\begin{array}{c}\text { Cornwall Fees held " in } \\
\text { capite" }(\text { i.e. demesne })\end{array}$ & $\frac{1}{2}$ fee & 70 \\
\hline 1630.2 & I $6 \mathrm{I}$ & $\begin{array}{l}\text { See also: Nos. } 33 ; 38 \text { to } 40 \\
45 \text { to } 46 ; 176 ; 179 ; \text { and } 193 \\
\text { to } 194 .\end{array}$ & $\begin{array}{l}\begin{array}{l}£ \text { Ioo, } 000 \\
\text { or }\end{array} \\
\qquad \mathrm{I} 73,537 \\
\text { gs. } 6 \mathrm{~d} .\end{array}$ & 97 \\
\hline
\end{tabular}

MEASURES AND “MEASURES” (Nos. 162-180).

\begin{tabular}{|c|c|c|c|c|c|}
\hline Date. & \begin{tabular}{|l} 
Ref. \\
Nos.
\end{tabular} & Matter. & & Statistics. & Pages \\
\hline 1086 & 162 & Hide, Scope of & .. & c. 400 acres & $4 I$ \\
\hline$"$ & 163 & I fiscal sulung perhaps & $\cdots$ & $\begin{array}{c}\text { I } 60 \text { fiscal } \\
\text { acres }\end{array}$ & 39 \\
\hline$"$ & I64 & I $\quad$, jugum $\quad, \ldots$ & $\cdots$ & $\begin{array}{l}40 \text { fiscal } \\
\text { acres }\end{array}$ & $\begin{array}{l}39, \\
153\end{array}$ \\
\hline., & 165 & Cornish fiscal Acre... & & $\begin{array}{c}\text { c. Io nor- } \\
\text { mal fiscal } \\
\text { acres }\end{array}$ & 38 \\
\hline $1125-1128$ & 166 & $\begin{array}{l}\text { Old measure of presum } \\
\text { seed for I acre }\end{array}$ & bly & $\begin{array}{l}\text { I acher- } \\
\text { setum }\end{array}$ & I $6 \mathrm{I}$ \\
\hline
\end{tabular}




\section{STATISTICAL INDEX OF TEXT-contd.}

Measures ANd "Measures" (Nos. 162-180)-contd.

\begin{tabular}{|c|c|c|c|c|}
\hline Date. & $\begin{array}{l}\text { Ref. } \\
\text { Nos. }\end{array}$ & Matter. & Statistics. $F$ & Pages \\
\hline $\begin{array}{l}\text { Hen. } I I- \\
\text { John }\end{array}$ & 167 & $\begin{array}{c}\text { A quarter (sometimes of } 8 \\
\text { bushels), as compared } \\
\text { with quarter in No.1 } 73 \text {, not } \\
\text { more than ... } \quad . .\end{array}$ & $\frac{1}{2}$ & 159 \\
\hline$"$ & 168 & $\begin{array}{l}\text { This smaller quarter ap. } \\
\text { proximates to }\end{array}$ & $\begin{array}{l}\text { I horse } \\
\text { load }\end{array}$ & 160 \\
\hline 14 Fohn & 169 & $\begin{array}{c}\text { The King's carthorses have } \\
\text { I busbel each (old, small } \\
\text { measure), of which the } \\
\text { quarter sells at ... }\end{array}$ & rod. to $\mathrm{I} /$. & 160 \\
\hline c. 1240 & 170 & I Hide $=4$ Virgates $=$ & $4^{8}$ acres & 37 \\
\hline ", & 171 & " $=\quad, \quad=$ & 256 acres & $3^{8}$ \\
\hline t. Hen. III & 172 & 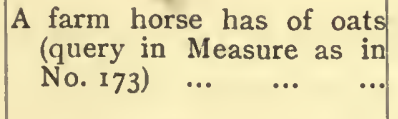 & & 160 \\
\hline $\left.\begin{array}{c}\text { Hen. III to } \\
\text { Hen. VII }\end{array}\right\}$ & 173 & $\begin{array}{l}\text { Quarter }=8 \text { bushels of } \\
64 \text { lbs. (old Troy) each, } \\
\text { each lb. made up of }\end{array}$ & $\begin{array}{l}\text { eat } \\
s\end{array}$ & $15^{8}$ \\
\hline t. Ed. I & 174 & $\begin{array}{l}\text { Bedfordshire - demesne } \\
\text { carucates, - average of .. }\end{array}$ & $91 \frac{1}{5}$ & $I_{4} I$ \\
\hline 1279 & 175 & $\begin{array}{l}5 \frac{1}{2} \text { Hides Arable }+5 \text { Hides } \\
\text { of Meadow, Pasture, and } \\
\text { Marsh }+(\text { query })=\end{array}$ & II $\mathrm{r}$ & 140 \\
\hline t. Ed.I & 176 & $\begin{array}{cccc}\text { Allowance } & \text { of } & \text { a } & \text { destrier } \\
\text { oats } & \ldots & \ldots & \ldots \\
& \cdots & \ldots\end{array}$ & hel & 160 \\
\hline$"$ & 177 & $\left|\begin{array}{cccc}\text { Allowance of a } & \text { cart-horse in } \\
\text { oats } & \cdots & \cdots & \cdots\end{array}\right|$ & $\frac{1}{4}$ bushel & 160 \\
\hline
\end{tabular}




\section{xxxvi Domesday and Feudal Statistics}

STATISTICAL INDEX OF TEXT-contd.

Measures and "Measures" Nos. 162-180-contd.

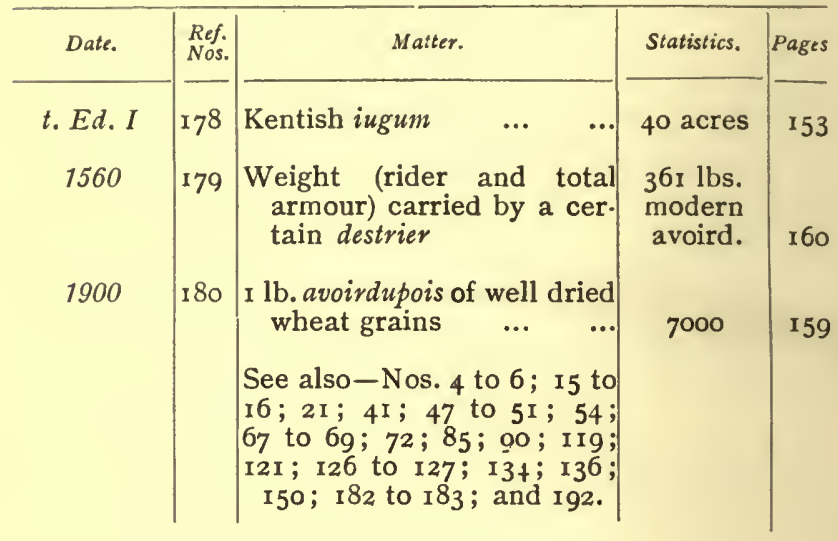

POPULATION (Nos. 181-188).

\begin{tabular}{|c|c|c|c|c|}
\hline Date. & $\begin{array}{l}\text { Ref. } \\
\text { Nos. }\end{array}$ & Matter. & Statistics. & Pages \\
\hline Heptarchy. & I 81 & Population of England & $\begin{array}{c}\text { c. I, }, 500,000 \\
\text { to } \\
2,000,000\end{array}$ & 29 \\
\hline , & 182 & Part of England; land of ... & $\begin{array}{l}250,000 \\
\text { families }\end{array}$ & 29 \\
\hline t. Bede & 183 & Isle of Wight; land of & $\begin{array}{l}\mathrm{I}, 200 \\
\text { families }\end{array}$ & 29 \\
\hline 1086 & 184 & population & I, 124 & 29 \\
\hline 1347 & 185 & $\begin{array}{c}\text { England and Wales; popu } \\
\text { lation }\end{array}$ & $4,000,000$ & $\begin{array}{r}5, \\
121\end{array}$ \\
\hline
\end{tabular}


STATISTICAL INDEX OF TEXT-contd.

Population (Nos. 181-188)-contd.

\begin{tabular}{|c|c|c|c|c|}
\hline Dale. & $\begin{array}{l}\text { Ref. } \\
\text { Nós. }\end{array}$ & Matter. & Statistics. & Pages \\
\hline 1377 & 186 & $\begin{array}{c}\text { England and Wales; popu. } \\
\text { lation } \quad \ldots\end{array}$ & c. $2,700,000$ & $\begin{array}{r}5 \\
121\end{array}$ \\
\hline 1688 & 187 & $\begin{array}{ccc}\text { Houses in } & \text { England } \\
\text { Wales } & \ldots & \ldots\end{array}$ & $1,300,000$ & 115 \\
\hline 1696 & 188 & $\begin{array}{l}\text { Population in England and } \\
\text { Wales } \\
\text { See also: Nos. } 31 \text { to } 39 ; 43 \text {; } \\
45 \text { to } 46 ; 58 \text { to } 63 ; 75 ; 84 ; \\
99 ; 107 \text { to } 108 ; 122 \text { to } 123 \text {; } \\
\text { I37; I41 to } 144 ; 146 ; 157 \text { to } \\
\text { I58; IGI and I90. }\end{array}$ & $\begin{array}{c}5,500,000 \\
\text { to } \\
7,000,000\end{array}$ & 115 \\
\hline
\end{tabular}

PLACES AND PARISHES-ENGLAND (Nus. 189-190).

\begin{tabular}{|c|c|c|c|c|}
\hline Dale. & $\begin{array}{l}\text { Ref. } \\
\text { Nos. }\end{array}$ & Matter. & Statistics. & Pages \\
\hline 1371 & 189 & Parishes in England (less & & \\
\hline & & Cheshire) $\ldots \quad \ldots \quad \ldots$ & 8,600 & $3 \mathrm{I}$ \\
\hline ", & I 90 & $\begin{array}{c}\text { Population per parish } \\
\text { See also: Nos. } 42 \text { to } 44 .\end{array}$ & c. 300 & 31 \\
\hline
\end{tabular}

PRE-DOMESDAY.

See Nos. 1 to $2 ; 31$ to $33 ; 81$ to 83 ; and 181 to 183 . 
xxxviii Domesday and Feudal Statistics

STATISTICAL INDEX OF TEXT—contd.

SOCAGE (No. 191).

\begin{tabular}{c|c|c|c|c}
\hline Date. & $\begin{array}{c}\text { Ref. } \\
\text { Nos. }\end{array}$ & Matter. & Statistics. & Pages \\
\hline 4 Hen. IV & I9I & $\begin{array}{c}\text { Cornwall ; Socage in capite } \\
\text { See also No. 159. }\end{array}$ & nil & 70 \\
& & &
\end{tabular}

YORKSHIRE (Nos. 192-194).

\begin{tabular}{|c|c|c|c|c|}
\hline Date. & $\begin{array}{l}\text { Ref. } \\
\text { Nos. }\end{array}$ & Matter. & Statistics. & Pages \\
\hline 1086 onwards & 192 & Liberty of Ripon; acres in & c. 40,000 & $\begin{array}{l}63 \\
127\end{array}$ \\
\hline $20 \mathrm{Ed} . \mathrm{III}$ & 193 & Fees, W. R., Yorks ... & c. 150 & 69 \\
\hline $4 \mathrm{Hen} . \mathrm{IV}$ & 194 & $\begin{array}{l}\text { capite (i.e. demesne) } \text { held in } \\
\text { See also : Nos. } 88 ; 133 ; 145 ; \\
\quad 148 \text {; and } 151 \text { to } 153 .\end{array}$ & c. 12 & \\
\hline
\end{tabular}




\section{SUMMARY OF INDEX AND TABLES.}

(But not including detailed statistics in latter).

STATISTICAL INDEX.

\begin{tabular}{|c|c|c|c|c|c|c|}
\hline & & & $\begin{array}{c}\text { Direct } \\
\text { Entries. }\end{array}$ & $\begin{array}{l}\text { Under } \\
\text { other } \\
\text { Heads. }\end{array}$ & $\begin{array}{c}\text { Table } \\
\text { Entries }\end{array}$ & $\begin{array}{c}\text { Total } \\
\text { Entries. }\end{array}$ \\
\hline Agriculture ... & $\cdots$ & $\cdots$ & 30 & 42 & 15 & 87 \\
\hline Domesday ... & $\ldots$ & $\ldots$ & 50 & 16 & 20 & 86 \\
\hline Feudal Service & $\ldots$ & $\ldots$ & 81 & Io & 16 & 107 \\
\hline Measures and & Measure & & 19 & 29 & 7 & 55 \\
\hline Population ... & $\ldots$ & $\ldots$ & 8 & 35 & 5 & 48 \\
\hline Places and Pari & shes & $\ldots$ & 2 & 3 & - & 5 \\
\hline Præ-Domesday & $\cdots$ & ... & - & II & - 3 & 14 \\
\hline Socage & $\ldots$ & $\ldots$ & I & I & 二 & 2 \\
\hline Yorkshire $\quad \ldots$ & ... & ... & 3 & 7 & + & 14 \\
\hline & Totals & $\ldots$ & $19+4$ & 154 & 70 & 418 \\
\hline
\end{tabular}

\section{TABLES FROM THOMAS RUDBORNE'S}

\section{WINCHESTER HISTORY,}

Under the year 1083, but presumably written in the reign of Henry the Sixth.*†

3 grains of barley, dry and round make I iach (pollex).

12 inches

3 feet

$5 \frac{1}{2}$ yards

20 (sic) *1 by 4 perches

$\begin{array}{ll}, & \text { I foot (pes). } \\ " & \text { I yard (ulna). } \\ & \text { I perch (pertica). } \\ , & \text { I acre (acra). }\end{array}$

"I foot (pes).

"I yard (ulnu)

"I acre (acra).

* + The author may of course have used older materials, but Section 11 seems inconsistent with a date earlier than Hen III (vide p. 159), and the Escuage Tables could scarcely apply prior to Ed. I (the amount being fixed, vide etiam p. 96); all the items however [saving that one noted $\left({ }^{*} 2\right)$ as not understood], appear proper to the 15 th cent.

* This is an obvious error, presumably of the pen. 
TABLES FROM THOMAS RUDBORNE'S WINCHESTER HISTORY-contd.

I penny (denarius) [called Starelyng, round without clipping, will weigh 32 grains of wheat, in the midst of the ear (spica) ]

weighs 32 wheat grains. 20 pence weigh I ounce.

I2 ounces, according to the English currency (cursus)

8 lbs. of wheat , I lb., i.e., 20/make I gallon (lagena).

8 gallons [make a bushel (modius), according to the measure (mensura) of London]

8 bushels (modii)

250 lbs. of sterlings ${ }^{* 2}$ (sic)
,

, I quarter

I London measure.

" I bushel (bussellus).

4 virgates (virge) ${ }^{*} 3$ make I Hide being 64 acres of land.

5 Hides make I Knight's Fee " 320 ", ,

Each Knight's Fee will give for Scutage 40/" " 1 6o acres of land i.e., (, $\frac{1}{3}$ Knight's Fee, i.e., $\left\{\begin{aligned} \text { I } 06 \frac{1}{2} & \text { (sic) acres of }\end{aligned}\right.$ ( land ... ... ...

I $\frac{1}{4}$ Hides, i.e., $24^{* 1}$ (sic) acres of land , , , , , $20 /$

$\frac{1}{5}$ Knight's Fee, i.e., 64 acres of land ... M , M , 12)- (sic).

$\frac{1}{10}$ Knight's Fee, i.e., 33 (sic) acres of land Io/$\frac{1}{6}$ Knight's Fee, i.e., 20 acres of land .., , , , , , $24 d . \frac{3}{4}$ (sic).

*2. The explanation of this entry is unknown to the writer.

*3. Suppose a clerical error for virgata.

*4. A slip of the pen, or printer, for four score. 


\section{CHAPTER I}

\section{DOMESDAY STATISTICS}

"Cæterum tota vita ita fortunatus fuit, vt exteræ \& remotæ gentes, nihil magis, quam nomen eius timerent. Prouinciales adeo nutu suo substrauerat, vt sine ulla contradictione primus censum omnium capitum ageret, omnium prædiorū redditus in tota Anglia notitiæ suæ per scriptủm adiiceret, omnes liberos homines cuiuscunq; essent, suæ fidelitati sacramento adigeret."

[Willielmi Malmesburiensis, curâ H. Sauile.]

TMESDAY BOOK gives much informa- Population tion which can be displayed in statistical counties. tables-to wit, as to population, ploughteams, ploughlands, hidage, past and present values: it should be borne in mind that thirty-four counties are enumerated; of the remaining six, Monmouth was then in Wales, Northumberland and Durham are not found: in the Yorkshire "Survey" Cumberland and Westmoreland are slightly noticed, and most of North Lancashire, the remainder of that county being found under Cheshire. For fuller information as to the recorded population, reference can be made to Ellis' "Introduction to Domesday Book" (1833), from which the underwritten figures are taken: in the thirty-four counties (as then 
constituted) is a total of 283,242 recorded folk, of which, in rough percentages :

$\begin{array}{lrrrrr}\text { Villans } & \ldots & \ldots & 108,456 & \ldots & \% \\ \text { Bordars } & \ldots & \ldots & 82,624 & \ldots & 29 \\ \text { Servi } & \ldots & \ldots & 25,156 & \ldots & 9 \\ \text { Sokemen } & \ldots & \ldots & 23,090 & \ldots & 8 \\ \text { Liberi Homines } & \ldots & 12,384 & \ldots & 4 \\ \text { Burgesses } & \ldots & \ldots & 7,968 & \ldots & 3 \\ \text { Mesne Lords } & \ldots & 7,871 & \ldots & 3 \\ \text { Cottars } & \ldots & \ldots & 6,819 & \ldots & 2 \frac{1}{2} \\ \text { Tenants-in-chief } & \ldots & 1,400 & \ldots & \frac{1}{2} \\ \text { Homines } & \ldots & \ldots & 1,287 & \ldots & \frac{2}{5}\end{array}$

making a sum of 277,055 , or some $98 \%$ of the whole, the most prominent of the remainder being 995 presbyters, 920 coliberti, 749 bovarii, 565 radknights, 467 female servants, 427 porcarii, 354 Frenchmen, 207 of the establishment of Bury St. Edmund's Monastery, I 78 paupers, I 59 censarii, I 37 milites, I I I Welshmen, I I I fishermen, and 108 salt-workers. It should be noticed that almost four-fifths of the population are comprised under villans, bordars, cottars, and servi, and in the following table (p. 3) it will be seen that in more than three-fourths of the thirty-four counties, nine-tenths of the population are composed of villans, bordars, cottars, servi, sokemen, and liberi homines.

The county constitution table is intended to show features peculiar to districts: in each shire the whole of the recorded population is accounted for, save from $5 \%$ to $0 \%$, and all classes are noted which amount to or exceed $1 \%$ in all of the thirtyfour counties. 


\section{COUNTY CONSTITUTION TABLE.}

\begin{tabular}{|c|c|c|c|c|c|c|c|c|c|c|c|c|c|c|c|c|c|c|c|}
\hline & 兽 & 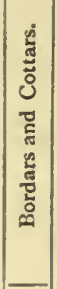 & फ้ & 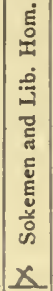 & तुँ & 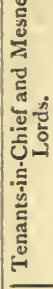 & 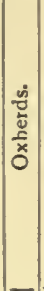 & 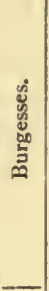 & 它 & : & 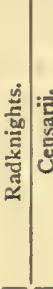 & 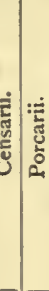 & 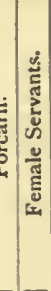 & 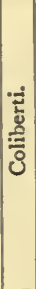 & 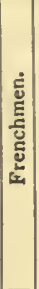 & $\frac{\dot{2}}{\frac{5}{v}}$ & 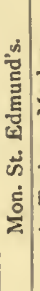 & 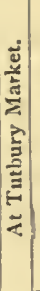 & ठేّ \\
\hline$d$ & 38 & $3 I \frac{1}{2}$ & 9 & 12 & 9 & & & & & & & & & & & & & & \\
\hline Beds & 47 & 30 & 12 & $2 \frac{1}{2}$ & $91 \frac{1}{2}$ & $8 \frac{1}{2}$ & $\ldots$ & $\ldots$ & .. & .. & $\ldots$. &.. & . . & .. & .. & .. & . & .. & 100 \\
\hline s & $41 \frac{1}{2}$ & 408 & $12 \frac{1}{2}$ & $\cdots$ & $94 \frac{3}{4}$ & $4 \frac{1}{5}$ & .. & $\cdots$ & .. & .. & .. &... &.. & .. & $\ldots$ & .. & .. & $\cdots$ & $98 \frac{1}{28}$ \\
\hline ks & $53 \frac{1}{2}$ & $24 \frac{1}{2}$ & $15 \frac{1}{2}$ & $\frac{1}{8}$ & $93 \frac{6}{6}$ & $5 \frac{2}{8}$ & .. & $\cdots$ & $\ldots$ & $\ldots$. & $\ldots$. &.. &. & .. & .. & .. & .. & . & 99 \\
\hline bs & $36 \frac{1}{2}$ & $41 \frac{1}{2}$ & $10 \frac{1}{2}$ & 4 & $92 \frac{6}{6}$ & $5^{\frac{3}{4}}$ & $\ldots$ & $\cdots$ & $\cdots$ & $\ldots$ & $\ldots$. &.. & . . & .. & $\ldots$ & .. & .. & .. & $98 \frac{1}{6}$ \\
\hline leshire. & 34 & 27 & $8^{2}$ & 2 & 71 & 7 & $7 \frac{1}{3}$ & $2 \frac{1}{2}$ & 1 & $1 \frac{1}{6} 6$ & 6. &.. & . . & .. & $1 \%$ & .. & $\ldots$ & . & $96 \frac{1}{0}$ \\
\hline wall. & $3^{2}$ & $43 \frac{1}{3}$ & $21 \frac{1}{3}$ & .. & $96 \frac{1}{2}$ & 2 & $\cdots$ & $\cdots$ & .. &.. & $\ldots$. & . . &. & .. &.. & .. & .. & .. & $98 \frac{1}{2}$ \\
\hline erby & $60 \frac{1}{2}$ & $23 \frac{2}{3}$ & $\frac{2}{3}$ & $4 \frac{1}{6}$ & 89 & $3 \frac{1}{3}$ & $\ldots$ & $4 \frac{2}{3}$ & .. & $1 \frac{2}{3}$. & $\ldots t$ & $\frac{1}{3} \ldots$ & ... & .. &.. & $\ldots$ & $\ldots$ & $\ldots$ & 100 \\
\hline n & $46 \frac{1}{3}$ & $28 \frac{1}{3}$ & 19 & .. & $93 \frac{1}{2}$ & $2 \frac{4}{5}$ & .. & $1 \frac{1}{2}$ & .. & $\ldots$. & .. & $\therefore 13$ & $\frac{3}{5}$. & .. & .. & .. & .. & . & $99 \frac{1}{2}$ \\
\hline 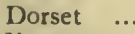 & $33 \frac{1}{8}$ & $42 \frac{3}{\frac{3}{\alpha}}$ & 16 & .. & 92 & $4 \frac{1}{8}$ & .. & 2 & .. & $\ldots$. & $\ldots$ &.. &. & .. & $\ldots$ & .. & .. & . & $98 \mathrm{i}$ \\
\hline . & $25 \frac{1}{2}$ & 50 & I I & $5\}$ & $91 \frac{1}{2}$ & $3 \frac{6}{6}$ & .. & $3 \frac{3}{3}$ & .. & $\ldots$. & .. & . . . & . . & $\because$ & $\ldots$ & .. & .. & $\cdots$ & $993^{1}$ \\
\hline ester & $43 \frac{1}{2}$ & $21 \frac{1}{2}$ & $24 \frac{1}{2}$ & $\frac{1}{x}$ & 90 & $3 \frac{1}{6}$ & $\ldots$ & $1 \frac{1}{5}$ & .. & $\ldots 1$ & $1 \frac{2}{8}$. &.. & .1 & $1 \frac{7}{6}$ & $\ldots$ & .. & $\ldots$ & . & 98 \\
\hline 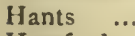 & 37 & $38^{\circ}$ & $16 \frac{1}{2}$ & .. & $91 \frac{1}{2}$ & 4 & $\ldots$ & $2 \frac{3}{4}$ & . & $\ldots$. & $\because$. &. &. & 1 &.. & .. & .. & .. & oc \\
\hline ord... & 398 & $26 \frac{1}{5}$ & 13 & & $79 \frac{4}{3}$ & 6 & 2 & $\because$ & 4 & $\ldots 1$ & I $\frac{1}{3}$. &.. & . $1 \frac{1}{8}$ & .. & $\because$ & .. & .. & $\cdots$ & 95 \\
\hline $\mathrm{r}$ ts & 37 & $39 \frac{1}{2}$ & $11 \frac{1}{s}$ & I & 887 & 5 & . & $2 \frac{3}{4}$ & $\ldots$ & I & ... &.. &. & .. & $I$ & $\ldots$ & .. & . & 0 \\
\hline c & $66 \frac{1}{3}$ & 163 & .. & & 84 & 4 & $\ldots$ & 10 & .. & $1 \frac{1}{2}$. & ... &.. & . . & .. & $\ldots$ & .. & .. & .. & 991 \\
\hline Kent $\quad$... & 54 & $28 \frac{1}{2}$ & 91 & & $92 \frac{1}{3}$ & I $\frac{5}{6}$ & $\ldots$ & $5 \frac{1}{2}$ & $\ldots$ & $\therefore$ & $\ldots$. &.. &. & . & .. & .. & .. & . & 99 \\
\hline ester. & 3 & 20 & 6 & $28 i$ & $93 \frac{3}{8}$ & $3 \frac{5}{6}$ & .. & I & $\ldots$ & .. & $\ldots$ &.. &. & . & .. & $\ldots$ & .. & . & 急 \\
\hline & $30 \frac{1}{2}$ & 16 & .. & $45 \frac{1}{2}$ & 92 & 2 & .. & 51 & $\cdots$ & ... & ... &.. & . . & .. & $\ldots$ & $\ldots$ & .. & . & 99 \\
\hline esex & $50 \frac{3}{4}$ & $35^{\frac{3}{7}}$ & 5 & $\ldots$ & 91 & 4 & .. & 2 & $1 \frac{1}{2}$ & $\ldots$ & ... &.. & . . & .. & .. & .. & .. & .. & 98 \\
\hline & $17 \frac{1}{2}$ & 37 & $3 \frac{2}{3}$ & 331 & $91 \frac{2}{3}$ & It & .. & $5 \frac{4}{3}$ &.. & .. & .. &.. & . $\ldots$ & $\cdots$ & $\cdots$ & $\ldots$ & $\ldots$ & . & 99! \\
\hline ants & $46 \frac{1}{5}$ & 24 ? & 9: & $12 \frac{1}{6}$ & $93 \frac{1}{1}$ & 4 & .. & I & .. & .. & ... &.. &. & .. & $\cdots$ & $\ldots$ & .. & .. & $98 t$ \\
\hline . & $45^{\circ}$ & 191 & & $26 \frac{2}{3}$ & $92 \frac{1}{4}$ & $3 \frac{1}{8}$ & . & 3 & $\ldots$ & 1. & $\ldots$ &. & . . . & $\ldots$ & .. & $\ldots$ & $\ldots$ & .. & $99 \mathrm{r}^{7}$ \\
\hline , & $52 \frac{1}{3}$ & 28 & $14 \frac{1}{3}$ & & $94^{\frac{5}{8}}$ & $4 \frac{2}{6}$ & . & $\cdots$ & $\cdots$ & $\because$. & $\cdots$ & . $\ldots$ & .. & $\cdots$ & $\cdots$ & $\cdots$ & $\cdots$ & $\cdots$ & 99 \\
\hline ans & $\bar{S}_{4}^{3}$ & $12 ?$ & $\therefore$ & & 98 & $1 \frac{1}{6}$ & $\because$ & 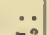 & .. & 1. & $\because \cdots$ &. & $\cdot \cdots$ & $\ldots$ & $\cdots$ & $\because$ & $\cdots$ & $\cdots$ & \\
\hline lon & $35^{1}$ & $23\}$ & 17 & & 76 & 4 & $7 \frac{1}{2}$ & $7 \frac{2}{8}$ & $\ldots$ & I & $3 \frac{1}{3} \cdot$ &. & . I & $\because$ & $\ldots$ & $1 \frac{1}{8}$ & $\cdots$ & $\ldots$ & $f \frac{1}{8}$ \\
\hline rset & $3^{8} \frac{1}{2}$ & $37 \frac{1}{3}$ & $15 \frac{1}{3}$ & $\because$ & 9I & $3 \frac{2}{4}$ & $\cdots$ & 3궁 & .. & $\cdots$. & $\ldots$ & . & . . & $1 \frac{1}{2}$ & $\ldots$ & $\cdots$ & $\therefore$ & $\because$ & \\
\hline & $54 \frac{1}{3}$ & $28 ?$ & $6 \frac{2}{8}$ & & 90 & $5 \frac{1}{3}$ & .. & $1 \frac{1}{2}$ & $\ldots$ & .. & &. &. & $\therefore$ & $\ldots$ & .. & $\ldots$ & I $\frac{1}{3}$ & 98 \\
\hline olk & $13 \frac{2}{3}$ & $30 \frac{1}{3}$ & $4 \frac{1}{2}$ & $41 \frac{1}{3}$ & 90 & 31 & .. & $3 \frac{7}{6}$ & $\ldots$ & $\ldots$. & $\ldots$ &. &.$\ldots$ & $\ldots$ & $\ldots$ & $\ldots$ & I & .. & \\
\hline & & $27 \frac{3}{5}$ & 11 & $\cdots$ & $92 ?$ & 3. & & 4 & $\ldots$ & $\ldots$. & $\cdots \cdot$ & .. & . . & $\ldots$ & .. & $\cdots$ & . & .. & $99 t$ \\
\hline & $56 \frac{2}{3}$ & $3 \mathrm{I} \frac{1}{8}$ & 4 & $\cdots$ & 92 & $5 \frac{1}{6}$ & $\ldots$ & $2 \frac{1}{2}$ & $\cdots$ & $\cdots$. & $\ldots$ & $\cdot \ldots$ & . $\ldots$ & $\ldots$ & .. & $\ldots$ & . & $\cdots$ & 99 \\
\hline ck.. & 531 & 27 & 13 & & $93 \%$ & $3 \frac{1}{2}$ & $\cdots$ & $\cdots$ & $\cdots$ & & & $\cdot \cdot \cdot$ & $\cdot \cdots$ & 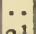 & $\cdots$ & $\cdots$ & $\cdots$ & $\cdots$ & $97 \%$ \\
\hline & $30 ?$ & 44 & 15 & $\because$ & 89 & $4 \frac{\pi}{8}$ & $\because$ & 3 & $\cdots$ & $\because$ & $\cdots \cdot$ & $\cdot \cdots$ & • & $2 \frac{1}{2}$ & $\cdots$ & $\cdots$ & $\ldots$ & $\cdots$ & $98 \frac{8}{6}$ \\
\hline Vorcester & $32 \frac{1}{5}$ & 383 & 141 & $\frac{1}{13}$ & 861 & $3 \frac{1}{5}$ & $1 \frac{1}{2}$ & 31 & 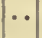 & 17 & $\cdots$ &. & - $2 \frac{1}{8}$ & $\cdots$ & $\cdots$ & $\cdots$ & . & $\cdots$ & $97 \frac{\pi}{4}$ \\
\hline Yorks & 63 & $22 \frac{1}{4} \mid$ & $\cdots$ & $5 \frac{1}{2}$ & & 4 & $\cdots$ & I & & & & & $\cdots$ & & & & & & \\
\hline
\end{tabular}


(34) W. out of $3 g(\operatorname{lng}):$ MAIN STATISTICAL TABLE.

\begin{tabular}{|c|c|c|c|c|c|c|c|c|c|c|}
\hline \multirow{4}{*}{$\begin{array}{l}\text { (a) } \frac{\text { earoon }}{(1080)} \\
\text { Dec.frac. } \\
\text { of } E \text {. }\end{array}$} & \multirow{4}{*}{ 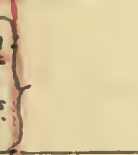 } & \multirow{3}{*}{$\begin{array}{c}\text { (Census } \\
\text { Ancient } \\
\text { Counties.) } \\
\text { Area, } 1891 . \\
\end{array}$} & \multirow{4}{*}{$\begin{array}{c}\text { ElLis. } \\
\text { Re- } \\
\text { corded } \\
\text { Pupula- } \\
\text { lion, } \\
\text { ro86. }\end{array}$} & \multicolumn{4}{|c|}{ Maitland. } & \multicolumn{2}{|c|}{ (a) Pearson. $l$} & learsor \\
\hline & & & & \multirow{3}{*}{$\begin{array}{l}\text { Hidage, } \\
\text { s065-86. }\end{array}$} & \multirow{3}{*}{$\begin{array}{l}\text { Dane- } \\
\text { geld, } \\
\text { circa } \\
\text { Ir } 50 .\end{array}$} & \multirow{3}{*}{$\begin{array}{l}\text { Plough- } \\
\text { teams, } \\
\text { Jo86. }\end{array}$} & \multirow{3}{*}{$\begin{array}{l}\text { Polential } \\
\text { Plough- } \\
\text { lands, } \\
\text { 1086. }\end{array}$} & \multirow{3}{*}{$\begin{array}{l}\text { Valets } \\
\text { in } \\
\text { Pounds, } \\
\text { 1086. }\end{array}$} & \multirow{3}{*}{$\begin{array}{c}\text { Valuits } \\
\text { in } \\
\text { Pounds, } \\
\text { ro65. }\end{array}$} & \multirow{3}{*}{$\begin{array}{l}\text { leaseor } \\
\text { Dec frac } \\
\text { of } f\end{array}$} \\
\hline & & & & & & & & & & \\
\hline & & c. $(1886)$ & & & & & & & & \\
\hline - 608 & Beds & 298,494 & 3,875 & I, I 93 & I, 106 & 1,367 & 57 & $6 \frac{1}{2}$ & $1,474^{\frac{1}{2}}$ & .583 \\
\hline \multirow{4}{*}{$\begin{array}{l}804 \\
\cdot 388\end{array}$} & Berks & 462,224 & 6,324 & 2,473 & 2,056 & 1,796 & & & & 41 \\
\hline & Bucks & 475,094 & 5,420 & 2,074 & 2,047 & 1,952 & 2,244 & $1,8(13) \frac{1}{2}$ & $1,785 t$ & \\
\hline & Cambs & 549.749 & 5,204 & 1,233 & 1,148 & I:443 & 1,676 & & & \\
\hline & Cheshire & 657,068 & 2,349 & 512 & & & & & & \\
\hline . 067 & Cornwall. & 868,208 & 5,438 & 155 & 227 & 1,187 & 2 , & 662 & $729 \frac{1}{2}$ & .42 \\
\hline - 206 & Der & 658,876 & 3,041 & 679 & ${ }^{*} 1121$ & 862 & & $461 \frac{1}{4}$ & 31.1 & \\
\hline .713 & Devon & $1,667,007$ & 17434 & 1,119 & $1,04 \cap$ & 5,5 & 7,972 & 3,2 & 115 & \\
\hline - 483 & Dorset & 632,272 & 7,8 & 1 & $2,4^{\gamma 2}$ & 1,7 & 2. & $2,656 \frac{1}{2}$ & $2,564 \frac{1}{3}$ & -450 \\
\hline . 533 & Essex & 937,028 & $16, \mathrm{C}$ & 2,6 & 2,364 & 3 & . & $4,784 \frac{1}{2}$ & 4.098 & - 9 \\
\hline \multirow[t]{2}{*}{.333} & Glouceste & 795,734 & 8,366 & 2,388 & 1,941 & 3,768 & $\ddot{s}$ & $2,827 \frac{1}{4}$ & $55 \frac{1}{2}$ & 4 \\
\hline & 1 & $\mathrm{I}, 037,704$ & 10,373 & 8 & 1,848 & 2,614 & 2,847 & & & \\
\hline \multirow{5}{*}{$\begin{array}{l}.696 \\
.767 \\
.495 \\
.150\end{array}$} & $\begin{array}{l}\text { Her } \\
\text { Her }\end{array}$ & $\frac{537,363}{106,161}$ & $5,3^{68}$ & 1,324 & 938 & $\begin{array}{l}2,479 \\
1,406\end{array}$ & 6 & 霄 & 1.804 & \\
\hline & Hunts & $\frac{400,1018}{234,218}$ & 4.92, & 1,050 & $\begin{array}{r}1,101 \\
713\end{array}$ & $\begin{array}{r}1,400 \\
967\end{array}$ & & o & $80 c^{3}$ & \\
\hline & Kent & $\frac{24,2}{995,344}$ & 12,205 & 1,224 & 1,058 & 3,102 & . & $5,140 \frac{1}{2}$ & 7. & \\
\hline & Leiceste & 527,124 & 6,772 & {$[? 2,500]$} & 1,000 & 1,817 & . & 7 & $491 \frac{1}{4}$. & $\bullet$ \\
\hline & & $1,693,547$ & 25,305 & 4,188 & 2,660 & 4,712 & 5,043 & & & \\
\hline \multirow{3}{*}{$\begin{array}{r}.385 \\
.579 \\
.029 \\
\end{array}$} & Mid & 181,301 & 2,302 & 868 & 856 & 45 & 4 & & & \\
\hline & Nor & $I, 308,440$ & 27,087 & {$[? 2,422]^{*}$} & 3,301 & 4,853 & . & $4, I$ & $2,219+$ & \\
\hline & Nor & 641,992 & $8,44 \mathrm{I}$ & 1,356 & 1,195 & 2,422 & 2,931 & 1,843 & $1,407 \pm$ & .167 \\
\hline \multirow[t]{5}{*}{.146} & Oxon & $\frac{539.752}{483,614}$ & $\begin{array}{l}5,030 \\
6,775\end{array}$ & $\begin{array}{r}507 \\
2,412\end{array}$ & 2,498 & $\begin{array}{l}1,99 \mathrm{I} \\
2,467\end{array}$ & $\begin{array}{l}1,2 \\
2,6\end{array}$ & & & \\
\hline & Rutland & 97,273 & & 37 & I 16 & [239]. & 4037 & & & \\
\hline & Salop & 859.516 & 5,080 & $\mathbf{I}, 245$ & I, I 79 & 1,755 & & & & \\
\hline & Somerse & $I, 043,485$ & 13,764 & 2,951 & 2,775 & 3,804 & & 4, & & \\
\hline & S & 749,601 & 3,178 & 499 & $45^{1}$ & 951 & I, 398 & {$[5$} & & \\
\hline \multirow{4}{*}{$\begin{array}{r}238 \\
.367 \\
. \quad 683 \\
\end{array}$} & & $\frac{952}{485}$ & & 18,2 & 2,350 & & & & & \\
\hline & Susse & $\times \frac{40}{93}$ & $\begin{array}{r}4,503 \\
10,410\end{array}$ & 3,474 & $\begin{array}{l}1,790 \\
2,170\end{array}$ & 3,0 & 1, & & t & \\
\hline & Warwic & $\frac{277,462}{57,4}$ & 6,574 & $1,33^{8}$ & 1,280 & 2,003 & 2,276 & & $\begin{array}{r}3,407 \\
953\end{array}$ & \\
\hline & V & 880,248 & 10,150 & 4,050 & $3, \mathrm{Sg} 6$ & 2,997 & 3,457 & & & \\
\hline \multirow{5}{*}{.025} & W & $\frac{480,560}{88,20}$ & 4,625 & 1,189 & 1,013 & 1,889 & $\cdots$ & 991 & $1,060+$ & $\cdot 133$ \\
\hline & & $3,882,848$ & & & 1,055 & & & & & \\
\hline & & 27,506 & $2 S_{3}, 242$ & & $30^{*}$ & 30 & & - & - & \\
\hline & & acre & & $\begin{array}{l}\text { Counties, } \\
\text { circa }\end{array}$ & $\begin{array}{l}\text { coun- } \\
\text { ties, }\end{array}$ & $\begin{array}{l}\text { coun- } \\
\text { ties, }\end{array}$ & $\begin{array}{c}\text { counties, } \\
52,354\end{array}$ & $\begin{array}{l}\text { coun- } \\
\text { ties, }\end{array}$ & $\begin{array}{l}\text { coun- } \\
\text { ties, }\end{array}$ & \\
\hline & & & & & & & & & & \\
\hline
\end{tabular}

* The Hides are avowedly overestimated (D. B. and Beyond, p. 409), including dormant ones and duplicates (D. B. sometimes states a total, and then repeats same Hides in particulars), to distinguish which both reading and counting are often necessary: the writer holds that the Norfolk carucates have no reference to Hidage (see note, p. 12) ; Yorks, Suffolk, and Rutland are omitted in the Danegeld total, but Derby and Notts together equate 1,121 Hides (here carucates).

Pearson adds thellhing to his freires:-

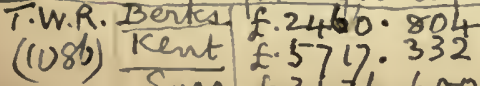




\section{Domesday Statistics}

The main siatistical table is a compilation, the Main acreage being from the census of $189 \mathrm{I}$ (ancient tatile counties), the population from Ellis, the valets and valuits from "pp. 665-669 of Pearson's "English History," and the rest from Professor Maitland's "Domesday Book and Beyond," with small additions.

As to population, some of the boroughs of Population I086 (notably London and Winchester) are 1377 . omitted in D. B. (Domesday Book), and presumably a considerable proportion of the inhabitants of West Yorkshire, and all in North Lancashire: however, the same persons are sometimes mentioned more than once, and females occur notably as ancillæ. In the present state of our knowledge, 2,000,000 total population would be an extreme figure for the forty counties of modern England for 1086 : it is probable, from the poll-tax returns of 1377 , that at that date the population might well lie between $2 \frac{1}{2}$ and 3 millions, and prior to the Black Death (1 348-49) $4,000,000$ and upwards, whereas $1,800,000$ might be a reasonable postulate from D. B. for 1086.

The hides in the table include the carucates Units of of the Danish districts and the sulungs of Kent, ment. and are estimated for the thirty-four recorded counties; for 1065-1086 they must be regarded as units of assessment, not in any obvious connection with area or value, and the underwritten equations seem to prevail in D. B. :

1 hide $=4$ virgates $=120$ fiscal acres.

1 carucate $=8$ bovates $=120 \quad$ "

I sulung $=4$ juga* $=120$ 9)

$$
\text { * Sce, note p. } 39 \text {. }
$$


The above terms were also used as mediæval areal measures, and when normal the same equations held; the variations are well known, e.g., I carucate might contain 64 acres ( 8 per bovate), or I hide, 5 virgates of 28 acres each, and so forth, so that it is necessary to know the mensuration in use at a given date in any particular manor when dealing with actual quantities (and yet at the same date in the same manor one equation might not be sufficient for all the lands in it-e.g., Ramsey Chartulary).

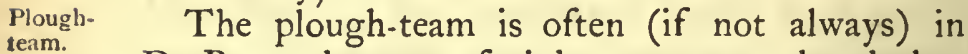
D. B. at the rate of eight oxen per plough, but there seem to have been actual ploughs of one, two, and four oxen, etc. : the enumeration of ploughs by the rate of eight oxen, of course, predicates no similar uniformity in practice. To record actual husbandry would have been difficult, but to assume a like number of oxen per plough a proceeding eminently rational for statistical purposes : it has been argued that the ploughs (as recorded) varied, which does not greatly flatter the wisdom of the compilers of our national record, and seems to be inconsistent with evidence like the following :

Fo. $304 a$ - - Bilton: 13 villans with 2 ploughs, and $;$ oxen.

Fo. 31 2a. -Borell : 2 villans with 6 oxen.

Fo. 314a.-Naburn : 3 oxen ploughing there.

Fo. 3 19a.-Stainton: 2 villans and 3 bordars ploughing with 2 oxen.

Fo. 3236.-Dringoe: I villan with 2 oxen.

Fo. 325a.-Newsholme: Ralph has now $\frac{1}{2}$ plough and I villan with 2 oxen.

Comparative values of implements and oxen.

Fo. 328a.-Aluengi : I villan and 2 oxen.*

* In the fourteenth century a plough might be valued at Is., and a single ox at about 15 s. ; if this comparison even 
that is to say, if D. B. counts a plough of two or four oxen as one whole plough on its system of record, the authors of this theory are burdened with the explanation of expressions as above.

The ploughland leaves some room for estima- Ploughtion, but Professor Maitland's figures show that it usually varies not widely from the teams; in some cases, as in the wasted Yorkshire manors, his surmise that the potential were the actual ploughlands of King Edward's day seems natural, but it does not meet an entry like the following from that county (fo. 299a): "land to 42 ploughs, $7 \frac{1}{2}$ there now, and formerly 46 teams." Again, he quotes as an instance of inexplicable divergence the Rutlandshire entries (fo. $293 b$ and $294 a$, and "Domesday Book and Beyond," p. 47I) of 48 ploughlands and 127 teams; but in the first place he seems to have omitted to note the teamlands were 14 plus 48 , and in the second that the villenage teams were probably those of small burgesses wealthy enough to have oxen in excess of the requirements of co-operative agriculture (a similar entry occurs on fo. $316 b$, Tateshalle), and rather comparable to farmers of the present day with arable from $I$ to 30 acres and a pair of horses.

Having just noted the fact of actual normal Area not hides of I 20 acres, and roughly allowed a plough- one team to a ploughland, the inference may seem to. plough. follow that a plough tilled 120 acres arable; but

approximately holds for the eleventh century, when the ox is taken at $2 \mathrm{~s} .6 \mathrm{~d}$., it seems inconceivable that the return of teams should be made from the actual implements in use rather than from the oxen. 
that is exactly what is not suggested, and which, I believe, can be demonstrated did not occur. Should any practical agriculturist honour my pages by his perusal, he must bear in mind there are who believe that not I20 acres, but even 180 , of arable were tilled in one year by one plough; certain it is he will be as little able to credit such unheard of practices in his art as the real existence of the dragons etc., of our monastic chroniclers. Whilst those abstracted from terrestrial affairs may conceive such astounding husbandry, he can never have been so fortunate as to have seen or heard of it (saving steam-ploughing) in any ordinary tillage routine of this country, nor will he allow the speculations of scholars the colour of superior knowledge. For what of credence would be given to the mathematician who persistently found a product of five from the addition of two and two, or to the classical instructor who rendered tenet and valet as tenuit and valuit; just so when writers on matters rural inform their readers of the nonexistence of the mediæval harrow, or gravely repeat that in ploughing an acre three miles (two leucx) are traversed, or that from $\frac{7}{8}$ to all $\mathrm{I}$ acre could be ploughed before mid-day.*

* But the profundity of the erudite mind is best discovered in a statement of the Regius Professor of Modern History at Oxford Oxford (p. 123, "Social England," vol. i.), where for every arithmetic. perch of " $16 \frac{1}{2}$ feet," for a furrow of "eleven inches broad," the "plow" is made to traverse the distance in " 4 or $4 \frac{1}{2}$ " rounds : with such a furrow of course 22 inches would be done per round, making just 9 journeys to and fro. It is to be hoped that the promoters of the Agricultural Education 
The first may possibly be an instance of college college farming, as it occurs in Professor Rogers' " History farming. of Agriculture," and is repeated in that singular unbending of University erudition to popular requirements ("Social England") by the writer on "Agriculture": though no one should be so exacting as to seek particular knowledge of so base an art from scribes of scholarly attainments, it may be pointed out that the Bayeux Tapestry and Loutrell Psalter $(c .1340)$ give undeniable pictorial representations of harrowing; again, D. B. (fo. 163 and 166 ) notes the practice-also the Burton Chartulary (III4), and, indeed, almost every custumal of any length, works which historical writers might well condescend to.

The second is quoted on p. $5^{8}$ (Taylor's "Analysis of Glos'ter Domesday Book," I 889)now, if the ploughing of an acre is too hard a problem in arithmetic to design on paper, any ploughman could testify he goes about Io miles per acre-i.e., with a furrow of 8 inches 12 miles, with a I 2 -inch one 8 miles, or 8 to $5 \frac{1}{3}$ leucæ.

The last occurs on p. 377 , note 4 ("Domesday Book and Beyond "), where the author corrects Miss Lamond's rendering of a noune, from 3 p.m. to I2 mid-day - the technical point I cannot pretend to discuss, but on p. 4I5 (vol. i., Ramsey

Extension System from our fountains of learning may commence at home, by giving those pioncers who are to enlighten the supposed darkness of the rural mind, such an elementary knowledge of arithmetic, as to place them on somewhat more even terms with the average carucarius in matters of simple addition, division, cte. 
Cart.), it may he observed, " apud dinariam" occurs in point of time before "ad nonam."

Reserving the discussion of how much land may or may not be assigned to a plough for the Valets and sequel, let it be noted that the valets and valuits Valuits. of 1086 and 1065 seem to represent the yearly profits of manors from whatever cause arising, and villani. that the term villani is used to distinguish the whole class of villans, bordars, etc., holding by base tenure from the liberi homines, and that tenants in villenage were free, except as against their lord. The Villan* proper would seem to have held from 7 acres (Wiceford, fo. I92a, D. B., 17 villans each of 7 acres) to 2 hides (Hanwell and West Bedfont D. B., co. Middlesex), with rights of pasturage ; let it be observed that these may be assessed rather than areal quantities, and that, in the case of villans of I and 2 hides (if areal), these were not all arable land, and may have been partly held at a rent. Seebohm (p. 102, "English Village Community") allows the average villan 20 to $2 \mathrm{I}$ acres in I086, but considers the A.S. gebur of 30 acres and 2 oxen, to answer to the normal villan of the same amount: according to the Middlesex Domesday an average villan is rated at I virgate; in the I. E. (Cantab.) at I $\frac{1}{2}$ acres; the later custumals give examples of holdings of $3,5,7 \frac{1}{2}$, 10, I 5, 20 acres, and virgates for the classes embraced by the D. B. villans, bordars and cottars, and precise definition of each

* Villans usually owe week work and precations, sokemen the Opera. latter; in $\mathbf{1} 32 \mathrm{I}$ (Hist. Pet.) free tenants as opposed to socagers appear to owe no works of any kind; see note, pp. 147-9. 


\section{Domesday Statistics}

grade is difficult. The estimate of 20-1 acres of workland for an average villan seems at any rate ample; possibly the Middlesex villans assessed in quantities exceeding $\frac{1}{2}$ hide may answer to the thirteenth-century class who held both at work and at rent, bearing in mind that Yorkshire, Middlesex, and Surrey were, in proportion to their teams, the counties most highly rated to gheld.

The bordar* occurs in each county, the cottar* Bordars in but 18 , nevertheless these terms are sometimes Cottars. interchangeable; the whole class may be broadly assessed up to ro acres, and where both occur together, the former considered the larger tenant. The bordar frequently had an ox or oxen, (sometimes also the cottar as distinct from the bordar); and custumals demonstrate that owners of 3 to 5 acres might have an ox or more, and subsequently I shall show that the holder of a virgate in the thirteenth century may often be rated at 4 oxen. The disappearance of the name (as a name) bordar is to be noted; also the presence of the class in towns, and the use of the terms $\frac{1}{2}$ villans and

* Bordars occur as pajing rent, D. B. $52 a$, from 20 masura, lllustraI 4s. ; $167 b, 38$ with $7 \frac{1}{2}$ pls., pay 8 s. ; 2646 , I renders 2s.; tions of as to amount of land from nothing up to 2 bovates (by 1 man), 'same from see $353 b$; and $84 b, 2$ held $\frac{v}{4}$ freely, and now hold; $139 b$, $4^{6}$ hold 8 ac. each; 190a, nine each 5 ac.- -together 2 pls. ; and the following 20 references (a selection only) from as inany counties demonstrate they often had separate ploughoxen, $14 a, 17 b, 52 b, 706,82 b, 94 a, 117 a, 120 a$ (13 to 1 pl., lowest in list), 1606, 1776, 180a (1 bordar 1 pl., highest found), $205 b, 215 b, 222 a, 241 b, 250 b, 259 b, 274 b, 285 b, 331 b$; on $186 a, 12$ work one day per week : Coscez and Cottars sometimes also had pls., thus Coscez $71 b$, two, I pl.; $72 a$, four, $\frac{1}{2}$ pl. ; $72 b, 6$ and 1 cottar, $\frac{1}{2}$ pl.; $74 b$, four, $1 \frac{1}{2}$ pls.; $74 b$, cight, I pl. ; Cottars, 976 , six, 1 pl. 


\section{2 Domesday and Feudal Statistics}

$\frac{1}{2}$ bordars, giving ground to suppose that occasionally full villans and bordars may be fractionally composed: in such a case (fo. $324 a$, D. B.) as 30 villans and 3 ploughs it is equally hard to imagine more than 30 men, less than 24 oxen, or as much as 900 acres of land (i.e., the "so-called" normal villan of 30 acres $\times 30$ ).

Servi. The servi were a class personally unfree, notable in S.W. England : in that name they soon disappeared, becoming presumably free labourers and cottars.

Sokemen. The sokemen* make a particular figure in E. England, and were under a lord with varying liberties as regarded their land-sometimes they had one lord for soke and another for commendation, and though not rarely performing base services may be referred to the class of liberi homines as opposed to tenants in villenage: at least on one occasion the I. C. Cant. enumerates as villans the sokemen* of D. B. (Wilberton, co. Cambs). In the absence of precise figures Seebohm's estimate of $22-3$ acres as an average holding is noted; in the custumals the smaller freemen seem often of less importance than holders of virgates in villenage.

The liberi homines* as a sub-class are inconsider-

* The population assigned to these classes is probably Popular quite unreliable, and members thereof must appear more than liberi homines, and sokemen, discordant with 3 per team ( 8 oxen) : taking the 9067 freemen and sokemen (Ellis) of Norfolk they can only be assessed at a like no. of teams as the 4731 villans, on the supposition that neither the lords nor other of the community had plough oxen. If the Domesday. 7723 villans of Lincs, are taken at above rate, there will be but $1 \frac{1}{2}$ oxen each left for 11,504 sokemen ( 47 I 2 teams in the 


\section{Domesday Statistics}

able out of Norfolk and Suffolk; Seebohm assesses Liberi their holdings at 42 acres; sokemen and liberi homines. homines may occasionally have been interchangeable terms, at the same time noting that the latter is used also for the whole class of superior tenantry, viz., tenants in chief, mesne lords, liberi homines, and presumably radknights and drenghs as distinguishing them from tenants in villenage.

The radknights, comprising the radchenistri and Radradmanni, were as peculiar to the W. Midlands as the sokemen and liberi homines to the E. shires; they amount to $2 \%$ of the recorded population, and may possibly be regarded as the antecessors of tenants by serjeantry.

The tenants in chief (about $\frac{1}{2} \%$ of the popula- Tenants in tion) held their lands directly of the King (sine medio) and the mesne lords (some $2 \frac{4}{3} \%$ of population) held of the former, or of other vassals holding of the King's tenants.

For the rest, it must suffice that the coliberti* Coliberti seem to have equated the buri,* and to have ranked and Buri.

co.) on the same theory; as the lords and others could scarcely have owned less than $\frac{1}{3}$ of the teams in either county it seems clear that freemen and sokemen are indeterminable both as to numbers and extent of holding. The application of the 4 ox per plough theory as in D. B. (Seebohm) is strikingly refuted here : the evidence for the rest of England (excepting Lincs., Norf., and Suff.) demonstrates the average villan could not have had less than 2 oxen.

* Prof. Maitland (p. 37, "D. B. and Beyond") endeavours These do to equate this class with the A.S. geburi, in order to appreciate not correthe villani; whilst admiring his sympathetic leanings to the spond with latter, such are scarcely the results of studies in Domesday Book. The geburs occur in the Laws of Ine; as servile tenants of Tiddenham ( 1 oth cent.), and in a like condition 


\section{I4 Domesday and Feudal Statistics}

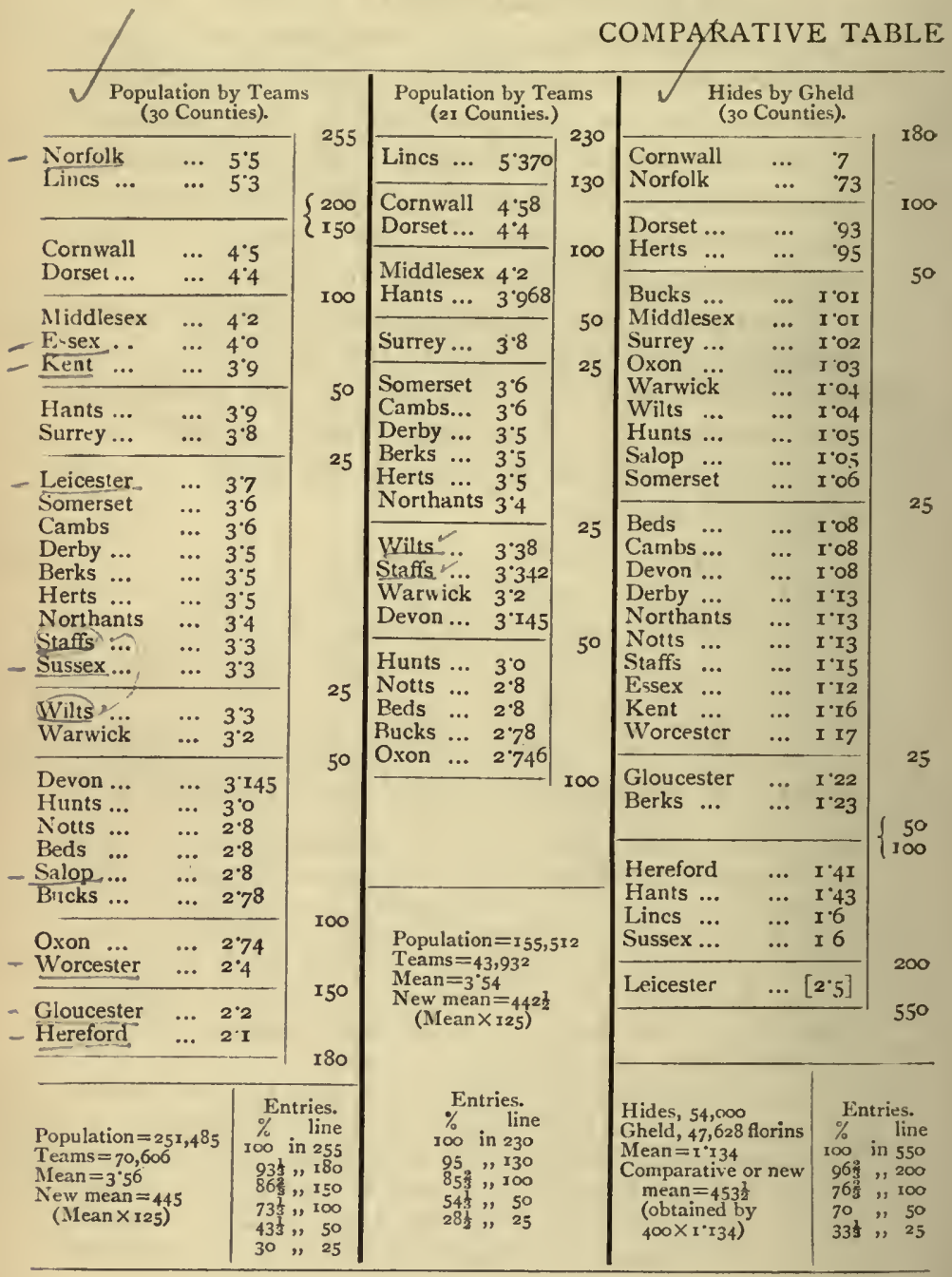


NO. I.

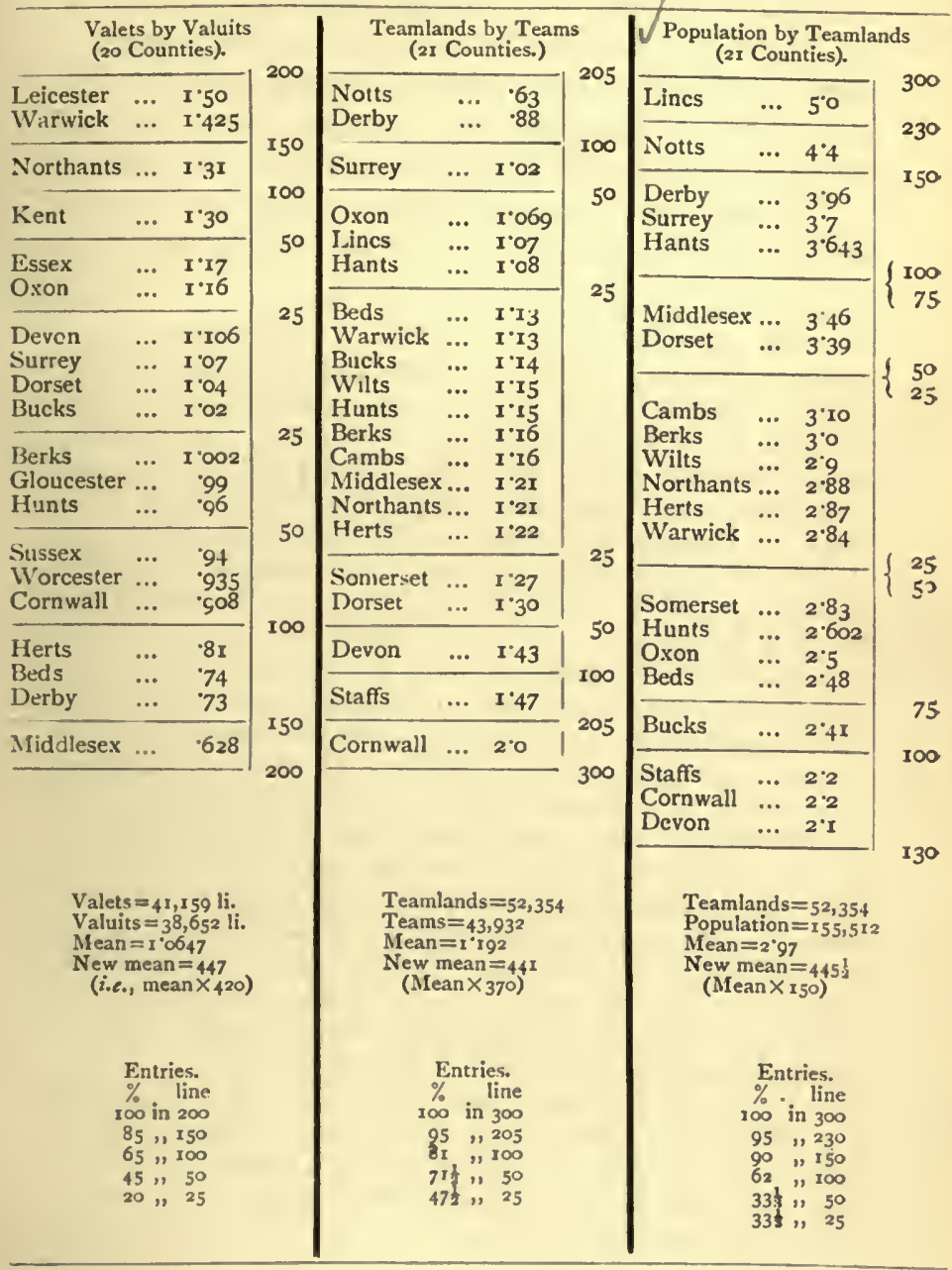




\section{I6 Domesday and Feudal Statistics}

between the villans and servi; that the ancillæ (most frequent in the W. Midlands) are regarded

Other classes. as female slaves; that the burgesses as a class are incompletely returned, that the censarii were a small class of free rent-paying tenants, and that the porcarii* and bovarii* may be considered both as servile herds, and free farmers of swine and oxen.

Turning to the relationship to one another of the figures in the Main Statistical Table, it is

(pedigrees) in co. Herts (Earle's Land Charters), the coliberti and buri being not (I believe) found in either placc: Ellis adds these 2 (latter) classes at 920, and references to 891 may be found in D. B. $38 a$ and $b, 39 a$ and $b, 41 a, 44 a, 57 b$, $58 a, 64 b, 65 a, 66 a$ and $b, 67 a$ and $b, 68 a, 71 a, 75 a, 77 b, 86 a$ and $b, 87 a$ and $b, 90 a, 91 a, 96 b, 101 a, 103 b, 120 a, 149 a$, $154 a, 163 a$ and $b, 164 a$ and $b, 165 a, 166 a, 174 b, 179 b, 181 b$, $182 a$ and $b, 239 b, 254 a, 260 a$, in 86 entries only (and to 19 coliberts of 1065 on $38 a$ and $163 a$ ); of these 552 occur on royal manors in 48 entries, 311 on church ones in 32 , and but 28 on 6 lay estates. The A.S. Rectitudines (Ioth or I Ith cent.) describe the gebur as on a thane's manor, and there Geburi as seems small room to doubt his correspondence with the villein villani. of D. B. (see note, pp. 147-9); the above shows that the coliberti (tho' numerous) were not a widely spread class, and scarcely to be found on lay estates. They seem to have as many or more oxen than the villans $[38 a, 163 a(b i s), 164 b]$; on fo. 386 six hold I Hide; they sometimes pay rent or produce $\left[38 a\right.$ and $\left.b, 39 a, 165 a, 174 b(b i s), 179^{b}(b i s)\right]$, and on the Estates of Westminster Abbey (174b), 6 coliberti sow 12 ac., and render IIs. 2 d., whereas 8 villans and 10 bordars sow 4 ac., and 10 vill., and 10 bord., 6 ac.; altogether their position as a class is of much uncertainty - they do not occur where Censarii are found, save in Dorset (Ellis).

Porcarii and

* The porcarii seem to have been the higher class and sometimes pay a rent in pigs; the bovarii often appear to replace the serri on the demesnes of Cheshire and Salop Manors, where they were presumably unfree ploughmen; a liber bovarius occurs on $183 a$. 
obvious that 28 separate divisions might be con- Remarks structed; of which 15 are set forth in the three parative following comparative accounts ; no extreme matheTable I.

matical accuracy being postulated in a matter where rough correctness is all that at present can be looked for. In the first table it will be noted that the comparison of like items gives satisfactory results; thus the hides of 1065 seem distinctly the antecessors of those which furnished the ghelds of the middle of the twelfth century, and the valuits of 1065 differ not widely from the valets of ro86, bearing in mind the absence of Yorks in the former class, and of most of the carucated counties in the latter. In these (Derby, Leicester, Lincs, Norfolk, Notts, Rutland, Suffolk, Yorks, and part of Cheshire) greater changes occurred than in hidated England, which the tables do not adequately set forth; nor are the wasted Yorkshire manors to be discovered in the comparison of Teamlands with Teams, the incompleteness of which table gives it a better appearance than it otherwise would have. In a country ploughed up to the maximum an excess of teams over teamlands would be expected, for the reason instanced above; according to the witness of D. B. the majority of counties had surplus arable.* It seems that no definite amount of land was in view by the expression of land to one team, which would indicate $\begin{gathered}\text { Land to } \\ \text { one team. }\end{gathered}$ different quantities respectively on the demesne and villenage; the distinction is often made, and the difference should not be overlooked, for on the land of the lord the land of one plough would include the assistance of the tenant, and on the

* That is more teams, could have been used with advantage. 


\section{Domesday and Feudal Statistics}

land of the villein the assistance rendered by the plough there was land to, must be subtracted in an areal estimate. Putting aside the probability that the tenant in villeinage worked his own land usually with less than 8 oxen, and taking D. B.'s Difference view of a full team, suppose the demesne plough of teamland, of demesne, and villeinage. could till $x$ acres per ann., and that the team of the men ( 8 oxen) could work $a+b$ acres (where $x=a+b)$; then $x+a$ would be the land of one plough on the demesne; and $(a+b)-a$ on the arable set to the villeins. This I believe was in the minds of the men of the hundreds when they state there could be so many more ploughs on the demesne and villeinage respectively; the matter would not stand exactly as above in actual practice where the occurrence of smaller ploughs of the men, would disturb the balance. Clearly a plough of 4 oxen* would do far more than half the tillage of one of 8 , and one of 2 beasts more than a quarter of it (smaller and lighter implements are predicated); however, when in the returns, mention is made of land to $2,3,4$ or more oxen, an artificial and roughly proportional comparison may be all that was in view, rather than details of practice, e.g., land to 2 oxen may mean about half the amount of land to 4 oxen, though the varying quantities of demesne and villeinage would further complicate each case. No frequenter of the towing-path would ever be likely to suppose

Oxen per plough in Wales, t. Hen. II.
* Probably common enough on villein lands ; cf. Gerald de Barri (t. Hen. II.) who states that the Welsh yoke 4 oxen in a plough more often than two: $W m$. de Malmesbury ( $t$. Hen. I.), writing of Wm. II., and Anselm, states, Vt aratrum sancte ecclesia, quod in Anglia duo boves validi छo pari fortitudine ad bonum certantes, id est, rex et arcbiepiscopus Cantuariensis debeant trabere nunc ove vetula cum tauro indomito iugata. 


\section{Domesday Statistics}

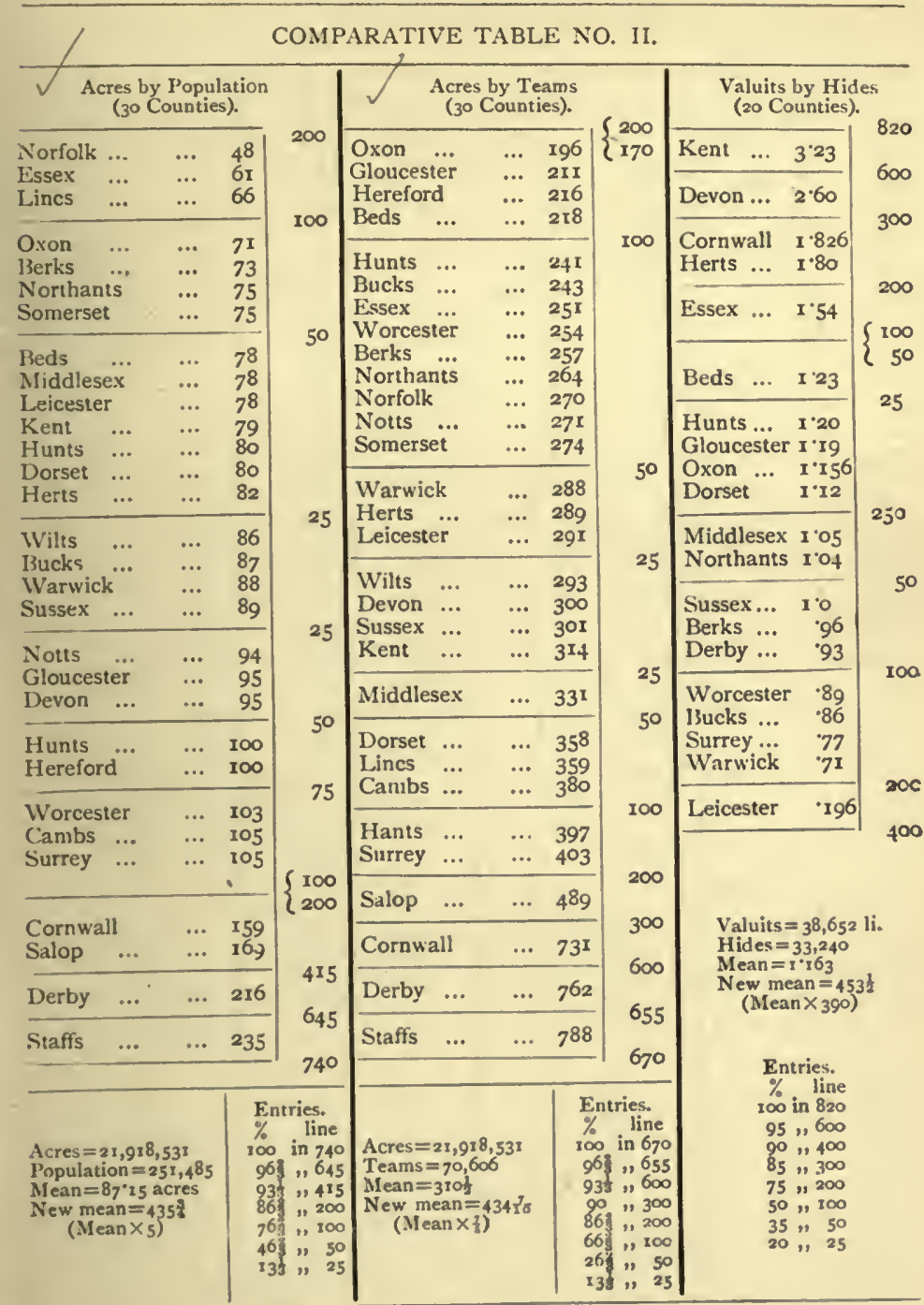


COMPARATIVE TABLE

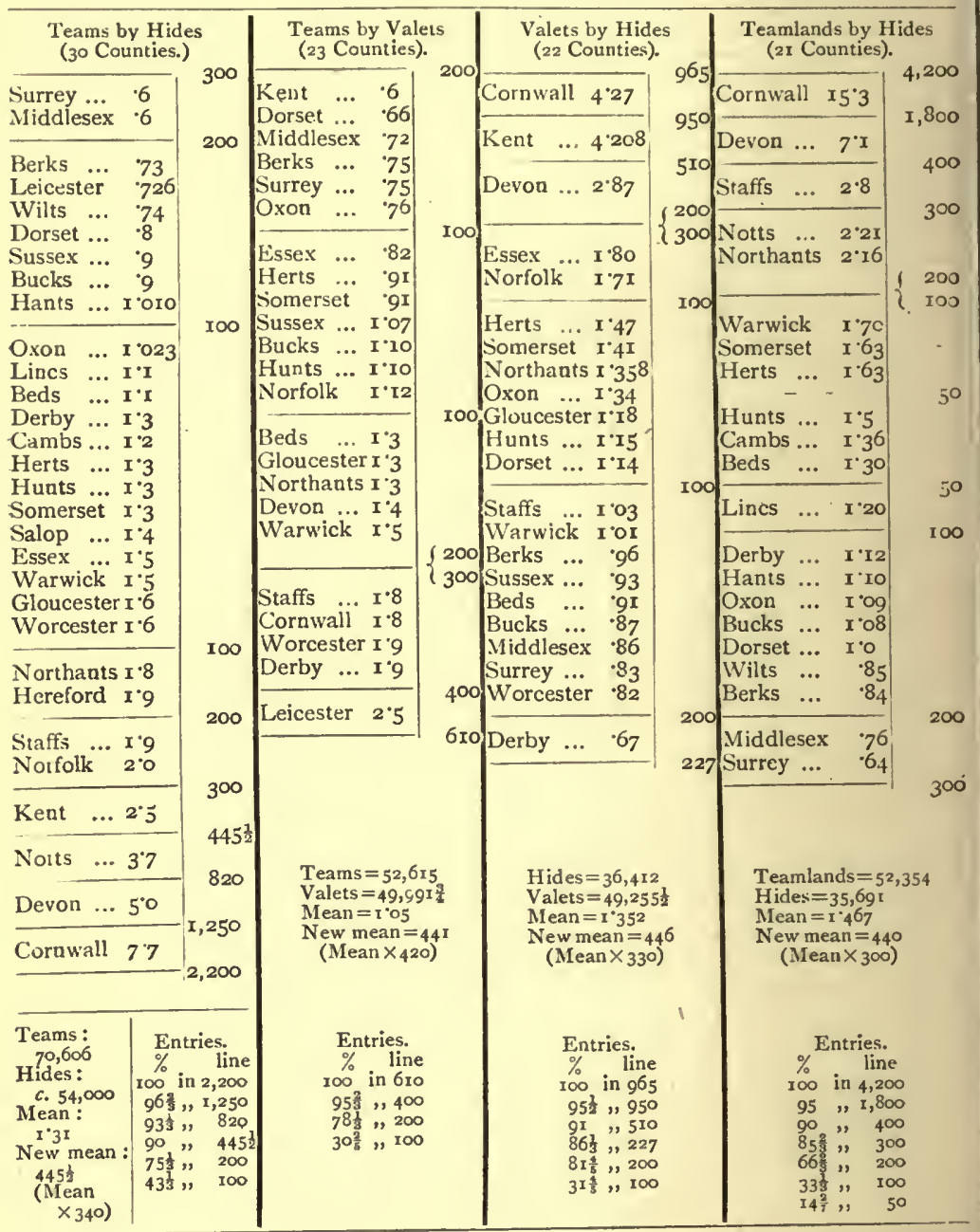


that eight men rowing in a "best" boat would be able to cover the Putney-Mortlake course in half the time of a single sculler; to a lesser degree this applies to tillage. Cott. Jul. A Teams of (eleventh century) gives a pictorial sketch. of 8 oxen.

2 ploughmen, I plough, 4 oxen; the Utrecht Psalter and Harl. 603 two of A.S. tillage, both showing I man, I plough, 2 oxen; Cott. Tib. B. V. (eleventh century) 2 men, I plough, 4 oxen; the Bayeux Tapestry 2 men, I plough, I beast; the Royal MS. (thirteenth century) I man, I plough, 2 oxen; the Chron. Roff. and Loutrell Psalter (both fourteenth century) respectively I man, I plough, 2 oxen; and 2 men, I plough, and 4 oxen: most of these are to be found in books, viz., Larking's D. B. of Kent; Utrecht Psalter ; Bayeux Tapestry, and Green's Hist. Eng. (illustrated edition). Nevertheless it seems equally Teams of certain that in England the normal demesne plough
8 oxen. consisted of the holder and driver, 8 oxen (or 8 animals partly oxen and partly horses), and I implement; not necessarily proving the absence of a lighter plough worked by less oxen on the land of the lord, for some occasions. The ploughs of the tenantry seem usually to have consisted of 8 oxen (as joined) when at work on the demesne ; the above illustrations indicate this not to have been the custom for working land in villenage, and I know no MS. evidence to the contrary.

Notably in Cornwall, the teamlands vary much from the teams, the correct explanation (alternate husbandry*) of which is noted by Professor Mait-

* D. B. $9 a$, pasture whence they ploughed 9 ac.; $80 b$, was pasture, now sowable. 


\section{Domesday Statistics}

land ; where portion of what is estimated as arable Rotations. is in grass, plainly less aration is demanded than on a 2 or 3 course shift. As a rule, (I) wheat, (2) barley and oats, (3) bare fallow would seem to have been the rotation; or a shift of (I) wheat, barley, oats, (2) bare fallow; and though there is no great amount of precise evidence, the comparison of Teamlands and Teams on the whole support the above.

To bring the fifteen tables into fair comparison Method of the following method has been used; in each table Tables. find a mean, and multiply same by a variable figure to produce a new mean, in such a way that the new means of each of the fifteen tables will be nearly alike; the new mean is then used for the construction of the comparative lines, the results from which are appended in percentages. Thus taking population by teams in 30 counties (Comparative Table I.) the mean is 3.56 (Population by Teams); the new mean is most conveniently taken as between 440 and 450 ; and therefore the old mean 3.56 is multiplied by 125 , product being 445. To 445, additions and subtractions of 25 , 50 , I00, I 50,180 , and 255 have been made; the results of which are now divided by the former multiplier (I 25), enabling lines of 25,50, etc., to be drawn in the actual table as shown; with the needful variations this convention has been used in all the fifteen tables, in order to discover their relative superiority.

The first table plainly shows that to state that William the Conqueror made the land to be assessed on an entirely fresh set of units, or that he 


\section{Domesday and Feudal Statistics}

so devastated the whole country that the value was greatly reduced twenty years after his landing, would not be supported by evidence, for the hides and valuits of 1065 roughly answer to those of circa 1150 and 1086 respectively in the comparisons as made; setting aside the comparison of like with like, the only table really satisfactory is Population that of Population by Teams, where (as should be varies as Teams. expected) a clear relation is established.

Except in the first table ( 5 divisions), the comparisons are slender; the remaining 10 divisions appear in Tables II. (3 divisions) and III. ( 7 divisions); the tables having been grouped by comparative results: Density (Table II.) gives the best yield, and the supposed relationship ( 1085 ) of Hides, Teams, Values, and Valuits (1065) is Slender demonstrated to have but slight grounds of support, results from other unlike Factors. for plainly the results from these items will not compare with the very artificial one of Acres by Recorded Population. In a country like England, both of 1085 and 1900 , there can be no very near kinship between the acres and population county for county, as plainly the flat agricultural districts will be more densely inhabited than the hills and moors; hence a fortiori as to the remaining 9 divisions which yield an inferior result. The areas of counties in Maitland's D. B. and Beyond are from the Agricultural Returns, 1895 , and his results from them used here,-though the figures in the Main Statistical Table in this book are from the Census Table, 1891-the difference is not great. 


\section{CHAPTER II}

\section{FEUDAL STATISTICS}

"Eodem anno rex Angliæ pater transfretauit de Normannia in Angliam, \& apud Wodestocke fecit Gaufridum filium suum, Comitem Brittanniæ, militem : qui statim post susceptionem militaris officii, transfretauit de Anglia in Normanniā, \& in confinibus Franciæ \& Normanniæ militaribus exercitiis operam prastans gaudebat se bonis militibus xquiparari \& eo magis ac magis probitatis suæ gloriam quæsiuit, quo fratres suos, Henricum videlicet regem, \& Richardum Comitem Pictauiæ in armis militaribus plus florere cognouit. Et erat eis mens vna, videlicet, plus crteris posse in armis: scientes, quod ars bellandi, si non præluditur, cum fuerit necessaria non habetur. Nec potest athleta magnos spiritus ad certamen afferre, qui nunquam suggilatus est. Ille qui sanguinē suum vidit; cuius dentes crepuerunt sub pugno; ille qui supplantatus aduersarium toto tulit corpore, nec proiccit animum proiectus; qui quotiens cecidit, contumacior surrexit, cum magna spe descēdit ad pugnam. Multum enim adiicit sibi virtus lacessita; fugitiua gloria est mens subiecta terrori. Sine culpa vincitur oneris immensitnte, qui ad portandam sarcinam impar, tamen deuotus occurrit. Bene soluuntur sudoris pramia, ubi sunt templa Victorice."

[A.D. 11 78 ; Rogeri de Hoveden* Annalivm, curâ H. Sauile.]

* Rog. de Houeden - Justice Itinerant, A.D., I $189-90$; $I$ Ric. I., Rot. Pip. 


\section{Domesday and Feudal Statistics}

A.S.

Charters.

I $\mathrm{N}$ Saxon $\dagger$ charters from the 7 th century onwards grants are made as the land of so many manentes, cassati, tributarii, and the terms mansæ, mansiunculæ, hida londe, sulungs occur as well as ploughlands, yoklets, and acres, some avowedly and others presumably by way of estimation: plainly not all equating each other, tho' some of them synonymous. Now it so happens that sometimes the numerical estimate agrees with that of Domesday; for example before 988 Woldham came to the Bishop of Rochester for 6 Sulungs (Reg. Roff.) which estimate is repeated 1086 (D. B. s.v. Oldham); in 948 Edred restored to the church at Winchester 100 mansæ at Downton and Ebbesburn (K. 42I) which by Domesday was I 00 Hides in the time of Cnut, and the same less 3 in 1065 (fo. 65a). Edgar in 972 ( $K^{*}$ 570) granted to Pershore perpetual freedom in their choice of abbot, in which deed upwards of 300 mansæ in Glos'ter and Worcester are named, and tho' in 1086 the Abbot had not actual possession, he had rights over a similar number of Hides (D. B.); in 725 Ine granted 12 manentes to Glastonbury in Sowey (K* 74 ) which had I 2 Hides in 1086 ; in 984 Ethelred's charter to the nuns of Shaftesbury names "twen tiwe hiwe at tissebiri," where a like number 1086; in 998 (Reg. Roff.) are some 6 Sulungs at Bromley (with further estate in Andrede's Wood) by measure, and in 1086, ten teamlands and 6 Sulungs at the former place, and should any dislike of the above by reason of their

$\{$ Norman \}

$\dagger$ In Norman charters, the land of a plough (caruca), frequently; no indication of a carucata ad gheldum (Ord. Vit.): the term Saxon is loosely used for the people of England (from whatever source deriving), before the advent of Duke William. 
scantiness and dates, reference to the paper on the Præ-Domesday Hide of Glos'ter by the editor of the Journal of the Bristol etc. Arch. Soc. should give full satisfaction for that county. Not that it is meant to say that all the land in Domesday, or any considerable portion thereof, can be accounted for in A.S. Charters, but that in so hard a comparison there are striking instances of similarity; not much do these deeds tell of actual Husbandry, but Seebohm (p. I 39 Eng. Vill. Comm.) cites Abba's Will A.D. 835 (K. 235) in support of the I 20 acre theory, which said testator bequeaths a $\frac{1}{2}$ Sulung with 4 oxen, 2 cows, and 50 sheep thereto, but as may be discovered from Domesday Sulings were fiscal as well as areal units, and should this half one mean 60 acres, at least 20 in grass would be wanted for the support of the stock named. Again teamlands in A.S. deeds were (at any rate some times) of estimate; thus A.D. 774 (K. I 2I) " et huius terræ estimatio v. aratorum" and A.D. 738 (K. 8.5) "id est decem aratorum iuxta æstimationem prouinciæ eiusdem."; further. A.D. IOI6-IO2O (K. 732) in Godwin's marriage contract "on Búrwaramerse other half 100 acres and thereto 30 oxen;"and 20 cows and Io horses, and ten theowmen "' and on fo. $12 b$ (D. B.) under Burwarmaresc, the lands is 12 pls., 4 in demesne, and 44 villans with 5 bordars have Io pls., which is not disagreeable (i.e. 4 dem. pls.) to the above, and also Add. Ch. I 9,796 in the Abbot of Evesham's lease of A.D. IOI 7-IO23, for 3 lives of 3 Hides to inware and other half to outware, but I man, 6 oxen, 20 sheep, and 20 acres sown to corn are to revert to the Minster on the termination of the agreement for Norton, which 


\section{Domesday and Feudal Statistics}

plainly shows the Hide not necessarily entirely arable, as is frequently supposed. In a grant of A.D. 8 I 2 by Cenwulf King of the Mercians (K. I 99) occur "mediam partem unius mansiunculæ id est an ioclet" and "hoc est terræ particula duarum manentium id est an sulung," suggesting

$$
\begin{aligned}
& \text { I mansiunculus }=2 \text { yoklets } \\
& \text { I sulung }=2 \text { manentes }
\end{aligned}
$$

or perhaps that the mansiunculus and manens here equate the yoklet and suling respectively. The Burghal and County Hidages are set forth in Prof. Maitland's D.B. and Beyond, and the Tribal Hidage therein named is here given, from Earle's Land Charters which dates the Saxon writing as of the Ioth or I Ith century.

leptarchic HIDAGE OF PART OF ENGLAND AT THE TIME OF THE lides. HEPTARCHY.
I. Myrcna landes
. 30,000
.. 7,000
2. Wocen sætna
20. Hwinca
21. Ciltern sætna
-3. Westerna ..
.. 7,000
4. Pecsætna ..
.. 1,200
5. Elmed sætna
.. 600
6. Lindes farona, with Hæthfeldlande
7. Suth Gyrwa ..
.. 7,000
.. 600
.. 600
.. 300
.. 600
.. 600
.. 900
.. 1,200
.. 300
.. 300
.. 300

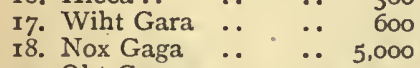
\begin{tabular}{rr}
$\ldots$ & 7,000 \\
$\ldots$ & 4,000 \\
$\ldots$ & 3,500 \\
$\ldots$ & 1,200 \\
$\ldots$ & 600 \\
$\ldots$ & 300 \\
$\ldots$ & 600 \\
$\ldots$ & 600 \\
$\ldots$ & 600 \\
$\ldots$ & 600 \\
$\ldots$ & 30,000 \\
$\ldots$ & 7,000 \\
$\ldots$ & 15,000 \\
$\ldots$ & 7,000 \\
$\ldots$ & 100,000 \\
\hline
\end{tabular}
14. Sweordora ..
15. Gifla .. $\quad \ldots$
16. Hicca .. ..
22. Hendrica ..
23. Unecungga ..
24. Avo Sætna ..
25. Færthinga ..
26. Bilmiga ..
27. Widerigga ..
28. East willa: .
29. West willa ..
30. East engle ..
3I. East Sexana
32. Cant Warena
33. Suth Sexena
34. West Sexena
Two Hundred Thousand and Two and Forty Thousand Hides and Seven Hundred Hides $(242,700)$

19. Oht Gaga .. $\quad \ldots \quad 2,000$

Hides

Why this early estimate is to be regarded as mere exaggeration I am entirely at a loss to discern, 
for (for aught I can find) England might well have had a population of $\mathrm{I}_{\frac{1}{2}}-2$ millions at the time of the Heptarchy, which would be answerable to the quantities in the table: for the ancient meaning of the word Hide (see King Alfred's trans. of Bede) would seem to be the land of one family, hence a population of $\mathrm{I} \frac{1}{2}$ millions or a little less might correspond to 250,000 families (bearing in mind that the table presumably falls far short of the 40 modern English counties); for example Bede names the Isle of Wight as the land of I, 200 families, and the recorded population of 1086 is I, I 24 by Ellis' cast. True it is that in 1065 the Hide is a fiscal unit, which is not to say that it at no time had been closely allied with reality, nor, because this artificial Hide of D. B. is computed at I 20 fiscal acres, is it to be therefore imagined that each head of a family in Heptarchic days had that amount of arable. For I would suppose that never tzo statute in the History of England could $\frac{1}{4}$ of the heads of arable, not families have been masters of so many ploughed the land of acres with suitable rights of wood, pasture and meadow for the extremely simple reason that 5 men would be but a scanty allowance for the working of such a tenement (by theory 2 men would be ploughing the greater part of the year, and if two 4 ox teams were used 4 of them). And plain it seems to be that this vision of fraternal harmony (at the rate of 120 acres of arable) would necessitate an overwhelming majority of the population in a dependent condition; that is to say, as labourers not necessarily servile, but under conditions of subjection as employed persons. This of course does not include such a supposed stipulation 
as but 30 of the 120 acres annually under the plough, as that would correctly be at the rate $1 \frac{120}{4}$ arable acres, but comprehends that of a 2 course shift, i.e., 120 acres ploughed, half in bare fallow. As I understand the theory of the "free ceorls"*

* The government Domesday Indexes (Ellis) enable the postulate that the A.S. "landowners" of 1065 were conOwners of siderably more numerous than the tenants in capite and mesne land T.R.E, and loris $(0,000-10,000)$ of 1086 ; but the method of the præDomesday List of proprietors allows no exactitude of stateT.R.W. ment; under the heading of Liberi Homines, Thanes, Sokemen, Homines, Fratres, Burgesses, and Radknights, 6,000-7,000 are enumerated, and the remainder (personal names) might well furnish the balance for a total 20,000. It may however be observed that a principle of selection, not easy to discover, has been applied to the Sokemen and Liberi Homines of 1065 (who account for some $\frac{3}{4}$ of the above 6,000-7,000), and as in 1086 these are practically excluded (in the 9,000-10,000 total), it is better to omit them, leaving $9,27 I$ mediate and immediate tenants at that date, against approximately $I_{3}, 000$ "landowners" in 1065 , and a rough equation of $\frac{A \cdot S}{A \cdot N}=\frac{3}{2}$.

Certain it is that many of the A.S. landowners had inconsiderable estates, as the following examples (all of the Wapentake of Claro, Yorks), collated with the Indexes in the Yorks Arch. and Top. Translation of Domesday, demonstrate ; save where stated all were lords of seemingly whole Manors, presumably had no other estate enumerated, and were above the rank of the so-called free ceorls:

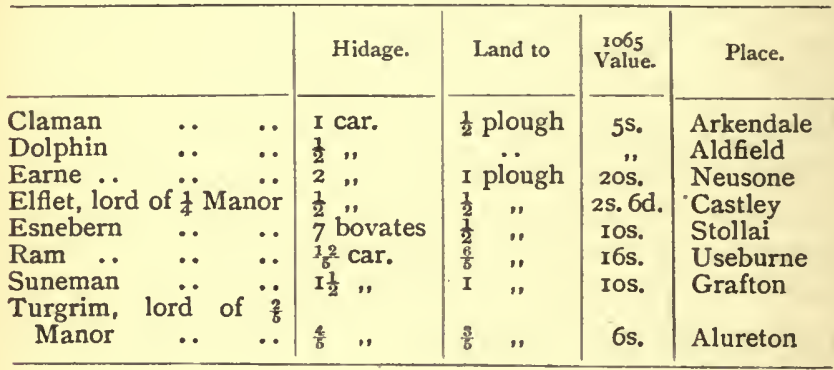


they were lords as above, which hypothesis is Modern incompatible with the non-subjection of the majority theories of the rest of the population to said small owners, Landand hence contains in itself the elements of its own impracticdestruction; tho' of course a nation of such proable. prietors might exist as an aristocracy of yeomen, and a democracy of farm-labourers in proper proportions. But the postulate seems rather to be that some half of the heads of families were peasant proprietors with such relatively enormous holdings as to be quite impracticable on the given conditions; whether or not this pleasing but unreal picture has had its originals in the congested atmosphere of our own fountains of learning, or was imported already constructed from across the ocean is beyond our power to discern, but so great an oddity is there in the appearance thereof, as to deny any kinship with the open air of the fields.

The Hide appears in the Heptarchic memorandum already cited, in the laws of Ine before A.D. 694, in the endorsement of Nunna's grant (K. I000), in A.D. 725 at the end of Wiglaf's

There were some $15,000-18,000$ places in the countics Places, recorded in D. B. 1086, and possibly Manors somewhat Manors, corresponding, giving each of the former an average popula- Parishes, tion of about 100 : in 1315-16 the vills fall far short of this 1086-1377. number, but no statistical results can be drawn from these returns of $9 \mathrm{Ed}$. II., owing to deficiencies and lack of uniformity; thus, in Yorks there are about the same no. of vills, as places in $20 \mathrm{Wm}$. I., but in certain counties the former are less than the no. of parishes recorded in 1371 , which in all England (save Cheshire) amounted to 8,600, answering to an average of 300 folk, or rather less per parish, as by the Poll Tax of 1377 ; in 16 Ed. II. (Parl. Writs, vol. ii.) is a classification of vills, $\frac{1}{2}$ vills, hamlets, and parts of vills. 
32 Domesday and Feudal Statistics

The Hide grant (K. 237), in A.D. 836 in King Alfred's and Hidage. translation of Bede, and has not disappeared in the I $5^{\text {th }}$ cent. (Memoranda L.T.R. Hil. 5 Hen. V. Rot. I 8) where is note of an allowance to the Sheriff for Hidage,* which is named still later in the Parliament Rolls of 20 and 23 Hen. VI., and 7-8 Ed. IV. From a period considerably before the Conquest its main importance seems for purposes of taxation, and presumably also for local rates, which latter usage appears to be maintained as long as the name persists; allowing that in Custumals and the Hundred Rolls etc. the Hide is further used as an areal measure for I 20 acres or other quantity. The artificial nature of Hidage plainly appears from the Domesday Tables, and in the Pipe Roll passing for $3 \mathrm{I}$ Hen. I. are notes of fines (pp. I 23 and I 25 printed vol.) that the Manors of Burwardescota and Etton shall from that date rate at a presumably lower hidage; Kings Wm. I., Hen. I., and Hen. II. taxed the lands by hides (2 I Hen. II. Pipe Roll-I marc allowed for carrying the summonses of Danegeld) and Ric. I. appears to have done so in his 6th year, Somerset yielding $£_{293}$ i 8s. 2d., Dorset $£_{24}$ I 3s. 9d., and Worcester f $_{9} 9$ I 2s., which at 2s. per Hide practically agree with the Domesday figures. In the Testa de Nevill (p. 295) in an inquisition of King John's, where $\frac{1}{4}$ of a carucate pays I od. to Danegeld in Denham, and 6 acres in the same place $3 \frac{1}{2} \mathrm{~d}$. (the word here may refer to a rate), and carucage was taken temp. John and Hen. III., which in some cases may have been raised by the Hide

* Quittance from Hidage (as well as Danegeld) may be noted in the Foundation Charter of Battle Abbey, $2 I \mathrm{Wm} . I$. 
rather than the plough,* and in 1222 (St. Paul's Domesday, Camd. Soc.) Hides are continually defended against both King and Sheriff, whilst the jurors of Draitone name exactions made in common by Hides, which supports the view that taxation

* W. H. Stevenson (writing in the E. H. R., vol. iv., Carucage. p. I09) challenges the statement that Carucage was ever levied on the plough-team itself (citing A.D. 1220); as the Close Rolls for that year (4 Hen. III., 1220) contain writs (Rot. Cl. i. $437 a$ and $b$ ) to all the Sheriffs of England to levy 2s. on each plough, as it zuas joined on the morrow of the feast of St. John the Baptist last past, it would seem to require that extreme abstraction (so conspicuous a mark of the ex catbedrâ writer), to explain the union of Hides or Carucates on the morrow, etc. : the writ of course refers to the yoking of oxen in the plough-teams, and not to some absolutely meaningless junction of acre to acre at a particular date. The above [E. H. R., vol. iv., p. IO9] seems seriously enough written, but merely shows the modern usages of the Schools, whereby the critic can expound what he has either not read, or is incompctent to understand : these writs $(\mathrm{Cl}$. 4 Hen. III.) show that in Northants (and perhaps in all counties) the demesnes of all clerks and their rustics were exempted, and that the ploughs of their Knights and free tenants were not to be answered by the collectors in their rolls; Subsidy $\frac{242}{29}$ (marked $t$. Hen. III. in the official slips, and certainly of the time when Falkes de Breauté was in power) is presumably the return for this county (the best carucage known to the writer), stating the exemption of the prelates and their rustics, together with omissions of 9 other fees, honours, ctc., and responding for $26 I_{3} \frac{1}{4}$ ploughs (possibly from $\frac{2}{3}$ of the shire), as against 2422 teams in the whole county in I086 (D. B.), at which date were some 1356 Hides. There are other carucages in existence, but usually of little statistical value, omitting mention of exemptions, and parts of the counties otherwise collected; in addition to this there would be the usual mediæval tendency towards assessment rather Mediæval than enumcration (vide writ as above) : in $4 \mathrm{Hen}$. III., taxation. Yorks, and Lincs, pay $\oint_{2} 200$ and $f_{1} 4^{\circ}$ (the equivalent of 2,000 and 400 ploughs) respectively-figures which can scarcely deceive the most credulous. 


\section{Domesday and Feudal Statistics}

of this nature at least had not passed out of mind t. Hen. III., whilst rating as already shown con-

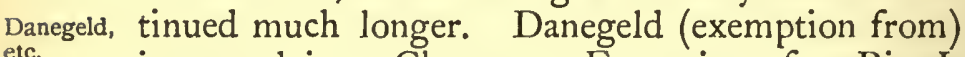
etc. is named in a Charter to Fountains of I Ric. I. (Ex Rot. Chart. 5 Ed. II. per Inspex.) and also in another* of II Ric. I. (pp. 8 and I 8 No. 67 Surtees Soc.), and the following from Madox's Formulare Anglicanum bear on the matter in hand (p. 238)-concession by Wm. I. of 8 Hides free from Geld; (p. 176) Feoffment or Confirmation of the Manor of Bromham by Wm. II. to Battle Abbey, free from ghelds, scots, hidages, danegelds, shires, hundreds, and armies; (p. 29l) grant and confirmation to Battle Abbey by Hen. I. free from all gheld, scot, shires, hundreds, hidage, danegeld, and expedition, and (p. 293) King Stephen quitclaims from ghelds, danegelds, Justices' and Sheriffs' Aid, $\uparrow$ " et ab omni exercituum expeditione."

Sheriffs $\dagger$ This Aid is named in Rot. Parl. (I2 Ed. IV., vi. 64) Aid.

* In 125 I Hen. III. (anno 36) granted lands in England, to Alexander, King of Scotland, free of Danegeld and Hidage (Rot. Parl., i. I I 5a).

A.D. 1472 , the Commons praying discharge of it, amongst certain old payments, when not able to be levied (citing an unobserved ordinance of 5 Ric. II., that all Sheriffs should account, and be discharged by their oaths) - Le Roy s'advisera. The Commons state that these "grete Fermes and Sommes under divers olde names axed" (giving details), "the said Shirefes know nat wher ner howe to levye," and the preceding article (vi., 63 ) respecting riots in Cumberland further illustrates the matter. The management of the King's interest in the county in 1472 would thus seem to have retained much of the form apparent in the published Pipe Rolls of Hen. II., which themselves appeared to be foreshadowed in 1086 (D. B.), in which are divers evidences of 
The Domesday Hides amount in number to about $67,000^{*}$ in 34 counties, and approximate to same circa I 50 (see Tables): a comparison with the Leicestershire Survey II 24-9 is made in Feudal England (Round), and another can be done from Gale's Register of the Honour of Richmond for Hang, Gilling, and Halikeld occasional Wapentakes 30 Hen. II. (I $183-4$ ), the carucates ${ }_{\text {Hides. }}^{\text {Stability }}$ of which are almost identical with those of the Book of Winton (1086); the reference occurs on pp. 24-6, and on pp. 22-3 presumably of the same date $(30 \mathrm{Hen}$. II.), are fines to the Sheriff computed at $4 \mathrm{~s}$. 7 d. per Tenmantele, (Io men equal to I 4 carucates), and it is curious to observe that taking the Domesday figures as I0,095 $\dagger$ (Maitland) the Danegeld would be $\oint_{1} 6_{5}-f_{0} \mathrm{I} 66$, at the above rate, and that the actual amount named in $3 \mathrm{r}$ Hen. I. (Pipe Roll) is forrt os. 4d., plus f.5 I 19s. 2d. by pardons. 'Some further illustrations of the occasional stability of Hides are given later from the H. R. of Ed. I., also comparison of the Survey of St. Paul's Manors (1222) in Essex, Herts, Middlesex and Surrey shows practical identity with 1086, and the appended table collating the Ramsey Abbey Manors

fiscal administration, thus: Beds, 209a (bis), 2096 (ter); Cambs, 197a; Chester, 262b; Essex, ii. 2 (bis), and 3 ; Hants, 50a; Hereford, 179b; Norf., ii. I I 8, I 19, and 276 (the royal treasury); Salop, 254a; Surrey, 30b; Wilts, 69a ; Worcester, I $72 a$.

* Prof. Maitland's Norfolk "Hidage" has been used here, though not agreeable to the evidence of D. B.

$\dagger$ For Yorks; but land between Tyne and Tees (not in D. B.) is accounted for in $8 \mathrm{Hen}$. II. 
MANORS OF RAMSEY ABBEY IN HUNTS, BEDS, CAMBRIDGE, NORTHANTS, AND HERTS I086, AND TEMP. ED. II.*

Examples of continuity of Hidage.
Hunts. Normancross Hundred.

\begin{tabular}{|c|c|c|}
\hline & & \\
\hline nton & Io $\mathrm{H} .4$ & Io H. 4 c. \\
\hline & $7 \frac{5}{8} \mathrm{H}$ & $7 \frac{5}{8} \frac{1}{8}$ \\
\hline $\begin{array}{l}\text { odinton } \\
\text { Teston }\end{array}$ & $2 \frac{1}{2} \mathrm{H}$. & \\
\hline $\begin{array}{l}\text { Weston } \\
\text { Brington }\end{array}$ & .. то $\mathrm{H}$. & \\
\hline $\begin{array}{l}\text { Brington } \\
\text { Bytherne }\end{array}$ & $7 \mathrm{H}$. & 4 c. $15 \mathrm{H}$. \\
\hline $\begin{array}{l}\text { therne } \\
\text { alton }\end{array}$ & 4 H. ! & $H$ \\
\hline & & $\mathrm{H}$ \\
\hline
\end{tabular}

Hunts. Leystonestane Hundred.

\begin{tabular}{|c|c|c|}
\hline & I086. & t. Ed II. \\
\hline Giddinge & .. not in & $7 \mathrm{H}$. I c. \\
\hline Dillington & $\therefore 6 \mathrm{H}$. & $6 \mathrm{H}$. \\
\hline
\end{tabular}

Hunts. Tolesland Hundred. Io86. t. Ed. II.

Offorde $\quad . \quad 4 \mathrm{H}$.

Em in $\mathrm{g}$ forde ... I8 or $19 \mathrm{H}$. I8 H. 2 c. E m in $\mathrm{g}$ forde alia .. 5 or $6 \mathrm{H} . \quad 5 \mathrm{H}$. Gyllinge $\quad \cdots \quad 5 \mathrm{H}$. $5 \mathrm{H}$.

Hunts. Hyrstington Hundred.

Stukeley $\quad \ldots 7 \frac{1086 .}{7 \mathrm{H}_{.}} \quad \frac{\text { t. Ed. II. }}{7 \mathrm{H}_{\text {. }}}$ Ripton Ab. .. to H. 2 c. . $\mathrm{H} .2 \mathrm{c}$. Broughton .. $9 \mathrm{H}$. $9 \mathrm{H} .4 \mathrm{c}$. Wistowe. .9 H. 3 c. 9 H. 2 c. Haliwelle .. $9 \mathrm{H} .2 \mathrm{c} .9 \mathrm{H}, 2 \mathrm{c}$. Slepe $\quad .20 \mathrm{H} .3 \mathrm{c} .20 \mathrm{H} .3 \mathrm{c}$. Houghton .. $7 \mathrm{H} .2 \mathrm{c} . \quad 7 \mathrm{H} .2 \mathrm{c}$. Wilton $\quad .7 \mathrm{H} .2 \mathrm{c} .7 \mathrm{H} .2 \mathrm{c}$. Wardeboys ... Io H. 3 c. Io H. 3 c.

Therfield $\quad . \quad \frac{\begin{array}{r}\text { Herts. } \\ \text { I086. }\end{array}}{\text { I0․ H. }} \quad \frac{\text { t. Ed. II. }}{\text { Io H. c. }}$

\section{Bedfordshive.} I086.

Cranfield .. $\overline{\text { Io } \mathrm{H}}$.

Barton .. II $\mathrm{H}$.

Pekesdene ... $10 \mathrm{H}$.

Shitlingdon ... Io $\mathrm{H}$.

Graven -

hurst .. not in $\mathrm{I} \mathrm{H}$.

Holewelle . $3 \frac{1}{2} \mathrm{H}$. $3 \frac{1}{2} \mathrm{H}$.

Berford $\because 5 \mathrm{H}$. $5 \mathrm{H}$.

Cliston .. I H. I H.

t. Ed II.

Io H. 4 c.

Io $\mathrm{H}, 2 \mathrm{c}$.

Io $\mathrm{H}$. I $\mathrm{c}$.

Io H. 5 V.

$3 \mathrm{c}$.

Cambridgeshire.

\begin{tabular}{|c|c|c|}
\hline & Io86. & t. Ed. II. \\
\hline Gravele & . $\quad 5 \mathrm{H}$. & $5 \mathrm{H} .2 \mathrm{c}$. \\
\hline Knapwell & -. $5 \mathrm{H}$. & $5 \mathrm{H}$. \\
\hline Elsworth & $\begin{array}{c}\quad 9 \mathrm{H} . \mathrm{I} \mathrm{V} . \\
5 \mathrm{ac} .\end{array}$ & $\begin{array}{l}9 \text { H. I V. } \\
5 \text { ac. }\end{array}$ \\
\hline Stowe & $\cdots\}_{2} \mathrm{H}$ & $\int 3 \mathrm{H}$ \\
\hline alia Stowe & $\ldots\}$ & $2 \frac{1}{2} \mathrm{H}$. \\
\hline Broune & . I $\mathrm{I}$. & I H. \\
\hline Drayton & . $\frac{8}{8} \mathrm{H}$. & I H. \\
\hline Overe & . Ios H. & II H. 2 c. \\
\hline Girton & . $\quad 85 \mathrm{H}$ & $8 \frac{5}{8} \mathrm{H} . \mathrm{c}$. \\
\hline Borewell & .. IO $\frac{1}{4} \mathrm{H}$. & IO $\frac{1}{2}$ H. c. \\
\hline Charteriz & .. $\quad 2 \frac{7}{8} \mathrm{H}$ & 3 II. c. \\
\hline & $\begin{array}{c}\text { Northants. } \\
\text { I086. }\end{array}$ & t. Ed. II. \\
\hline Whiston & $\cdots$ & $5 \mathrm{H}$ \\
\hline Doddinton & $\ldots\}^{3}$ & I $\mathrm{H}$. \\
\hline Hisham & .. not in & $I_{\frac{1}{2}} \mathrm{H}$. \\
\hline Bernewelle & . $6 \mathrm{H}$ & $6 \mathrm{H}$. \\
\hline mington & .. $\quad 2 \frac{1}{2} \mathrm{H}$ & $3 \mathrm{H} .3 \mathrm{v}$. \\
\hline
\end{tabular}

* H. = Hide or Hides, V. =Virgate or Virgates, c. = carucate or carucates, and the date of the Survey of the record of Ed. II. is not headed, nor noted in margin, but is in body of text (Cart. Rams., Rolls Series). 
t. Ed. II. and Domesday demonstrates the point still turther. Records of the reign of Ed. I. frequently show the enquiry whether or not vills are "geldabiles," such contributing to the Sheriff"s aid for Hidage, etc. ; thus 39 Hen. III. (Salop H. R.) a usual rate is $4 \mathrm{~d}$. for motfey and the like for streetward per rateable hide (another point of interest in this record is the occasionally double description in terms of the fee and hide); also in Kirkby's Quest ( I 3 Ed. I.) in Staincliffe, Yorks, a common rate is $3 \frac{3}{4} \mathrm{~d}$. per carucate to the Wapentake fine (similar in amount to 4 s. $7 \mathrm{~d}$. per Tenmentale of I4 car.), and in Pontebell, (same co.), no fine is due, because held by acres and not by bovates. Some vills have exemption from these local rates (the lords having regalities, or as being held in alms may quit them), and further instances can be seen from the H. R. (7 Ed. I.) in Wilbraham Parva, Swaffham, Bolebek, and Coteham co. Camb. of defence against the King and Sheriff; of local rates (p. 337, Vol. II., Hoggeston), Hidage at 6d. per virgate; (p. 829, Vol. II., Badigton) Hidage and Frankpledge; (p. 407, V. II.) Pontage raised by the Hide for repair of the bridge over the Cam, and at Elyngton and Gidding co. Hunts (V. II., 7 Ed. I.) the so-called Hidage of the Abbot of Ramsey, presumably to furnish the 40 days' expenses of 4 knights whilst in the King's Service.

As to the areal Hide its variations may be of Areal particularly studied in the Ramsey Chartulary Hides. (Rolls Series) where at Shitlingdon c. I240 it is computed at 4 virgates of 12 acres each (i.e., 


\section{$3^{8}$ Domesday and Feudal Statistics}

48 ac.), and at Therfield of 4 virg. of 64 ac. (i.e., 256 ac.) with in other cases 3-7 virg. per Hide; in the H. R. (referring of course to the 5 counties given at large) it is-I think-the exception for Hides to be named, either for defence, or as areal measures, nevertheless there are indications of a varying no. of acres per Hide, *

* The E. H. R. (vol. v., p. I43, review by W. H. StevenDomesday son) states that measurements are never given in terms of the "measures." Hide and Oxgang, Ploughland and Yardland, as still frequently confused by antiquaries, which proposition postulates that the critic is better informed than Domesday Book; such a statement calls to mind the reply of the unfortunate authoress of the "New Atalantis," who had discovered some special Facts (concerning the Whigs, $t$. Anne) which were thought above her own Intelligence (i.e., information), and alleged in defence that her source was Inspiration, "because knowing her own Innocence she could account for it in no other Way." Some of the following references to Domesday demonstrate that the uniformity alleged in the E. H. R. is not agreeable to the Record: Cheshire (body of county), 263a, $266 a$-bovates occur in a hidated shire; (between Ribble and Mersey), 2696, 270a-one Hide is equated to 6 Carucates, which is amply borne out by the summary of 79 Hides (scotting), whereas the Hides and Carucates add to about $80 \mathrm{H}$. by above equation; and further the Hide is sometimes \{Cornish $\}$ valued at I6s. and the Carucate at 2s. 8d. ; Cornwall, 123a to " "acres." $125 a$ appears to prove the acre greater than the ferling, and from the Exon $D$. $B$. the former seems equal to 10 fiscal English acres, thus p. 92, Tretlant 4 ac.; p. 206, Tretlant (apparently same entry), I virgate and I acre; also p. 242, Delio, I virgate divided into $\mathrm{I} \frac{1}{2}$ acres and another land, suggesting $4 \mathrm{ferl} .=\mathrm{I}$ virgate $=3$ acres, which is rather supported by the Testa de Neville (2 I Ed. I., pp. 204-5), where the Cornish acre equals the Cornish carucate; Devon, ro4a, 1076 , I10a, the acre apparently normal, and the ferling the fourth of a virgate; Glos'ter, 162a, the Welsh carucates; Hereford, $181 a$ and $b, 182 b$, English and Welsh Hides; Kent, 
and Hides per virgate (at Haliwell, Hunts, a virg. of 16 ac., at Elyngton, Hunts, a Hide of 120 ac. in 5 virg., and at Gidding, Hunts, a Hide of 180 ac. in 6 virg.) and by collating the Ramsey Cartulary with itself and the H. R. it may be seen that in the same place changes occur at different times; thus at Dillington, Hunts, in 1279 (H. R.) the virgate contains I 8 ac., and about I 240 (Ramsey Cart.) $33 \frac{1}{2}$ ac. These Hides have of course no connexion with the amount of land ploughable by one team p. a., and it may be observed both from the Chartulary and the $H$. R. that certain holdings are "out of Hide," and that the com-

I $0 a$, half a solin and 3 virgates, the virgate being the fourth of a jugum (see Feudal England, p. 108), and 2a, $400 \frac{1}{2}$ acres make $2 \frac{1}{2}$ solins, which with the entries of the Rochester Custumal (p. I 53) of 40 acres per jugum, and the absence of further information in D. B., suggests that the solin might have contained 160 and not 120 fiscal acres ; Leicester, 2326 , 3 carucates less a virgate; $236 a, 5$ car. less 1 virg.; and 237a, one Hide of 12 or 18 car. la. ; Norfolk, vide ii. 168, 205,224 , and 237 , as instances of actual or computed measurements, which seem to have been not uncommon here, thus ii. $171, \frac{1}{2}$ league and 2 perches long by 4 quarenteens and 4 feet wide (in co. Bucks $145 a$, one Hide less 5 feet occurs); Northants, $219 b, 222 a, 223 a$ and $b, 225 a$ $(b i s)$, and $b$ (bis), 226b, $227 b$ and $228 b$ afford 11 unmis- Intertakeable instarices of bovates (oxgangs). added to or sub- mixture of tracted from Hides and Virgates; Notts, 2896 , a ferling "Domesurday." seemingly equated to a bovate; Rutland, 293b, 2 Hundreds each of 12 fiscal carucates; Salop, 253a, 255a, Fines of Welsh land, and 2606 , a ferling apparently of 10 acres; Suffolk, passim, presumptive actual or computed measurements; Yorks, 376b, 2 measurements of Pontefract castellate, and frequently the areas of manors, and the woods contained in same are given, sec p. 129, and note on p. 131 for co. Leics. 


\section{Domesday and Feudal Statistics}

putation by Hides may differ as whether against the King or the lord (Craunfield, co. Beds., p. 2, V. II., Rolls Series); this together with the changing no. of acres per Hide tends to indicate a possible solution of the great variations noted, on the supposition that the rural arrangements are constructed to fit the fiscal ones. Tho' taxation $\&$ rates are paid by the Hide, nevertheless individuals are liable and in defence for varying proportions; the acre is not the unit of assessment and it might well be that an artificial unit such as the Hide should contain in one place twice or more, than the acres in another, with the further fact of usually certain tenements being omitted from the reckoning-as a rule (if I have observed rightly) cottagers are not in defence, and both in the Chartulary and H. R. for the Ramsey Manors a tolerably close approximation of the details with the no. of Hides stated, is to be found, rather than exact coincidence. Further, Hides are to be sought

Fiscal Hides in Woods, and Marshes. in ground unoccupied and presumably defended by the lord of the Manor, thus D. B. (fo. 204b) the Ioth Hide wasted for the King's wood (Elintune), which same is noted in the Ramsey Chart. (t. Hen. I. and t. Hen. II.) as being in the wood of Walberge ; the Abbot of Croyland's 5 Hides in the Coatham Marshes (I086-I 279 compared in the - sequel) ; and at Beolege (D. B., fo. 175a) in plain and wood 2 I Hides, said wood being 6 leagues by 3 , and but 10 ploughs named: also the arable of the lord's demesne is sometimes out of Hide, and not rarely the hidation is given first for the Manor, and then for its components, i.e., demesne 
and villenage. Could we transfret the centuries doubtless a landowner would be able to indicate the exact boundaries of his property, and likewise inform of its total Hides, and indicate exactly by whom each item of taxes and rates was paidfurther it might be found that some tenants paid neither rates nor taxes, and others perhaps in proportion to their holdings in the common fields, the owner acquitting the demesne at a more or less arbitrary computation for arable, wood, and grass, by Hides, which may indicate different quantities of ground on 2 adjoining properties. Again either the whole estate may be, say, ro Hides, or but such portions of it as are concerned in defending them ; in Yorkshire (1086) there can be small doubt that Yorkshire wood and rough pasture is within the carucate, as the dimensions of same are often given and comprised within the larger areas of the Manorssee also Kelham's D. B. Illustrated (p. 23I); "took from this land I Hide of the aforesaid wood," and " $\frac{1}{2}$ a Hide of wood." Now tho' it might have been practicable to fix a tax by the acre (instead of the Hide) on arable and grass enclosures, to bring woods and rough pasture land into a similar computation in proportion to their area would be a hard matter, premising that the latter would have to be sought out and measured, and charged at a suitable and varying rate. The scope of the Hide appears to approach to 400 Scope of acres in 1086, and its fiscal value then to be 120 Hide. ac. ; and possibly at that period a rough estimate - equivalent to $10,000,000$ acres (made up as of arable, several meadow and pasture, some wood, 
mills and other sources of profit) - may have been in view. The same conception may be made of the Knights' Knight's Fee, either the whole tenement being Fees. regarded as $\mathrm{X}$ fees, or but certain portions of it which total $\mathrm{X}$; thus a fief of 10 fees might be made up of 7 of old feoffment and 3 on the "dominicum," or one of I 5 fees, of 12 of old, 5 of new feoffment, and the "dominicum" quit, in which latter case there appears an excess of fees. Sure it is, there must ever have been a balance for the lord of the fee; in the former case the "dominicum" if entirely subinfeuded would be more than 3 fees, tho' only liable for that number; Bishop of to take an actual case the Bp. of Durham said he Durham's
Case Service, and and sends in a certificate of about 70 ; he can name Retainers. any ro of these as his service to the King, and his entire tenement comprises either ro or 70 fees, * the service being dischargeable from but a small portion of his estate. For taking the Bp.'s statement to be correct (and in an ordinary case I do not discover he ever paid on more), he is not bound to enfeoff a tenant who owes him I knight's service in $\frac{1}{10}$ of his estate-that, subject perhaps to custom, is a matter of arrangement between the $\mathrm{Bp}$. and prospective tenant, and an excess of fees above service is easily comprehensible. In 19 Hen. III. (Testa de Nevill, aid to marry), when all tenants paid on both old and new feoffment (theoretically), as conceded by the common council of the realm, the said Bp. (p. 373 T. de N.) pays $f_{2} 200$, equal, at 2 marcs per fee, to I 50 fees; but for the Gascony escuage circa $1242($ p. 4 I 2 T. de N.) his fees are

* As early as A.D. 1088, himself is a witness for his 100 milites (not necessarily all feudal tenants), - the Durbam $\mathscr{M S}$. is almost certainly from that of a writer, living $W m$. $I I$.: again Caerlaverock reports Anth. Bek had 160 men at arms in I300, whilst Ro. de Graystanes (contemporary), states, habuit de familiâ suâ $X X V I$ vexillarios et communiter de suâ sectâ $C X L$ 
noted as not unless IO, for the bishops had granted 4Os. per fee to the King, on all those fees they ought him for scutage, obtaining in return for themselves a like grant on all their fees, so that I $66-$ I 242 the Durham bishoprick seemed to contain 70 and 150 fees, the whole however being not unless Io. Now plain it should appear that an immediate tenant's estate was never likely to be completely subinfeuded, and that the lord would reserve for himself some portion-the above case is extreme, but 'tis contrary to reason to suppose any tenant would systematically subinfeud at what rate himself had been enfeoffed; nevertheless such unreal conceptions have caused erudite statements as to measurement by Hides-so many Hides, so many Knights, etc., etc. ; presumptions unwarranted by evidence, and very little flattering the sagacity of our predecessors.

Without much violence to probability it may be conceded that records of Hidage before 1086 existed (thus in D. B., in North Lancs, Staincliffe, Ewecross, parts of Cumberland and Westmorland are named no persons, stock, nor ploughs-save in I 6 vills near Preston, where unknown-but the Hidage is given), and it also may be allowed that 5-6 Domesday Hides make an average Fee (as Average a grant to a lay tenant in cap.), but that is not to say that the first feoffment (presumably before the Book of Winton was written) was made by Hidation ; certain it is that even in one county (Yorks) the subinfeudations vary greatly, thus I 205, 7 foln, in Scawsby (Honour of Tickhill) $2 \frac{1}{2}$ carucates make a fee (Final Concords); temp.

milites, in the Scotch war-this of course must not be confounded with the now almost extinct service, and whether his retainers were milites or men at arms, any acquainted with the records of the period will not need to be informed they were probably mostly ad vadia nostra (i.e., of $E d$. I.). 


\section{Domesday and Feudal Statistics}

Hen. III. (L. R. Rolls Series V. ii., p. 736) Variations 60 car. make a fee in Swynton, etc., and in very con-
siderable. A.D. I 300 (I. P. M. Rog. de Moubrai, as cited in Grainge's Vale of Mowbray) I59 car. make a fee-these are extremes, but ample confirmation of variations in practice may be found in the Testa de N., Kirkby's Quest, and Knight's fees 3I Ed. I. (see vol. 49 Surtees Soc.), and it may be remarked that the average 5-6 Hides would be far from applying on the one hand to Yorks, or on the other to Cornwall. The burden of supporting the 4,5 , or 6 Hide theory falls on its promoters, and receives no assistance from the subinfeudations of tenants in cap. which are quite untrammelled by any show of uniformity-the following from Domesday may be noted,

Service.

Examples. Fee of Wm. Perci in Yorks

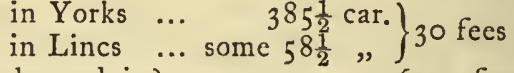
$\left.\begin{array}{l}\text { Fee of Earl of Richmond in } \\ \text { Yorks }\end{array}\right\}$ circa $1,172,\left\{\begin{array}{l}50 \text { fees in } \\ \text { Yorks }\end{array}\right.$ and the Abbot of Ramsey had in all well over 300 Hides and Carucates, with a service of 4 Knights, but ecclesiastical fees are on a different scale to lay ones. Further if Fiefs had been distributed on the 4,5 , or 6 Hide plan, the value of a fee in Cornwall would have exceeded one in Derby more than 6 times; a grant of course might well be as by Hides, premising no uniformity; some average fee there must be, but it would be conveying but scant information of the ages of 4 individuals, two 60 and two 20 , to state their average age as 40 . The $£_{20} \mathrm{p}$. a. value is another 
rough standard of occasional correctness for the fee in its transit to extinction, ( $I 2$ Car. II.), varied from $£^{2}-£_{3}$, but usually $£_{5}$ to $£^{8} \mathrm{p}$. a. (Book of Winton, by Pearson's values) to $£_{200}$ p. a. (Brady who lived in the latter period), so it is to little purpose to cite average values, unless the times to which they pertain are observed, as the following may demonstrate :

WAPENTAKE OF CLARO (INCLUDING LIBERTIES OF
RIPON AND KNARESBRO'). I065. I085.

From Domesday worth

3r Ed. r.

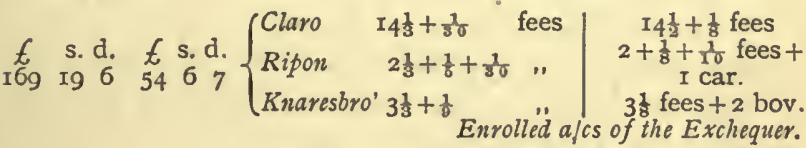

20 Ed. III.

ief lords were often in terms of the Hide and Carucate, appears from such records as the Testa, Kirkby's Quest, and Knight's Fees $3 \mathrm{I}$ Ed. I., but at no uniform rate, and clearly it would be easier to enfeoff in terms of already known Hides than in the often unknown acres; but this is not to say that 2,000 acres, or yet 5-6 Hides, would contribute a couple of pounds to an auxilium, for the tax was primarily on the Fee, and only on Hides and carucates (for feudal taxation) as being members of same. For example in 1346 (Book of Aids) the Prior of Marton holds I carucate in Appletreewick of the lord of Skipton Castle (Yorks) of the King, whence I4 car. make I fee, and therefore is assessed at 2s. IO $\frac{1}{2} \mathrm{~d}$. to a $40 \mathrm{O}$. aid, but in the same vill at same date Hen. de Kighley holds 


\section{Domesday and Feudal Statistics}

I bovate ( $\frac{1}{8}$ of I car.) of the Fee of Moubrai of the King, whence 28 , etc., and therefore owes $2 \frac{1}{4} \mathrm{~d}$. to the aid,- - the one in double proportion to the other, and having examined each entry of 3 wapentakes (Yorks) the writer can state that in no other sense is land taxed there than as part of a fief. For defect of service (fees were frequently unable to be found) doubtless the King had a right to claim, the Servitia being based on the render of the I4 Hen. II. Pipe Rolls; but the services of $\mathrm{I}, 000$ Hides in military tenure would be a phrase of no meaning, and would have to be ascertained from former inquisitions or returns.

Baronial

Charters,

Reciting the explanation of the Barons' CerI 66 . tificates in Feudal England, which with a slight amendment appears warranted by the Charters, definite if disputed services were due by the immediate tenants to the King in respect of their holdings, which debt is named more or less distinctly in some half these documents. The royal enquiry had been not as to the service due, but how many Knights had been enfeoffed by I Dec., I,I 35 (the day in which Hen. I. was quick and dead), how many since, and how many (if any) were due on the "dominicum." The former are specified as fees of the old feoffment in contradistinction to those of new (Dec. 2, I I 35 onwards), and the last enquiry refers to the balance between the service and the actual number of Knights enfeoffed, if such deficiency existed. The term Domini- " dominicum," tho' usually applied to land in the cum. hands of the lord in I I66, is also applied to the non-infeuded portion of the fee prior to I I 35 
and I 166 , thus Hugh de Dover (Kent) states that on his "dominium" are $2 \frac{1}{2}$ Knights* of new feoffment, and Earl $E u$ (Sussex) that on his "dominium" are $6 \frac{1}{2}$ Knights* whose names are, etc., and that he has no new feoffment. These certificates are the Primer of Feudal Tenures in England, but themselves contribute references to older times, which add to the scanty contemporary notices of Knight service, and it may be observed that no one in the days of Hen. II. (Certificates), RetrospecJohn and Hen. III. (Testa de N.), or Hen. III. ences of and Ed. I. (H. R.), seems to have been in doubt early enas to the early existence of the feudal system; in elder times the question would perhaps rather have been if such tenures were in usage before the Conquest (see Spelman's Works, rebutting that opinion which had been "legally" successful t. Car. I.). Hence the full burden of a demonstration lies on those who hold that tenure by Knight Service arose after 1086; the author of Feudal England has given (notably on pp. 295, 296) several retrospective references, to which I will add a few from the H. R. of Hen. III. and Ed. I. In 3 Ed. I. (p. 42, v. ii., p. 42) Wm. I. gave to Hugh ... and his heirs as $1 \frac{1}{2}$ fees the Manor and Castle of Oakham; (ibid.) Wm. I. gave to a certain redecessor of Gilbt. de Umfravill the Manor of Hamildon as I fee; (ibid.) the Manor of Preston formerly demesne of Wm. I. given by him to a certain Earl as $1 \frac{1}{2}$ fees ; (p. I66) 3 Ed. I., a note of a free socage from the time of Harold

* Id est, held by military tenants (whether knts. or not), in proportions equal to $2 \frac{1}{2}$ and $6 \frac{1}{2}$ fees. 


\section{Domesday and Feudal Statistics}

the King [commended to the promoters of the fraternal "ceorls"]; (p. 231) 39 Hen. III. a free hundred of the Bp. of Salisbury's belonging to the church from ancient feoffment of Offa the King ; (p. 337) 7 Ed. I. the Abbot of St. Albans holding of the King and adjoining Barony by service of $6 \mathrm{Knights}$ for 40 days, likewise enfeoffed by Offa ; (p. 337) another socage tenure from the time of the Conquest; (p. 637) 7 Ed. I. the Manor of Overton Waterville given to Wm. Olifareli at the time of the Conquest for $\frac{1}{2}$ fee, who after long holding, committed a felony (seems to have been held by the Sheriff D. B. 1086), whence forfeited till King John, etc., and on same page another Manor in same place of whose service the predecessors of the Abbot of Peterboro' were enfeoffed in the time of King Edward before the Conquest, and it is $\frac{3}{4}$ of a Fee. Now it may justly be remarked that these statements have little more than traditionary value, and that the service of Hen. III. Their and Ed. I. is quietly assumed to have been that authority. of Wm. I.; the same (I think) applies to like passages in the Testa de N. (pp. 295-6, Feudal England), which however can be surpassed (see pp. 3I 4-5, T. de N.) where "from the conquest" is the usual form of the Jurors of Jerdeburg Wap., t. Hen. III. Of course in theopresent age, with much less probability, a like statement* is not unusual, but it seems scarcely critical to accept the literal sense of records Hen. II.-Ed. I. as to the I Ith century, and to confront King Offa's Knights' fees is somewhat of a problem : in the T. de N. a pedigree may appear from the Con-

* Vide, works on Genealogy, County and Family Histories, etc. 
quest (p. 87, Ric. Cheven* who would answer well enough to Richard the hunter in D. B.), and the evidence in it and similar records is good to prove the general belief in those days of the antiquity of enfeoffment. Roger de Moubrai's charter (1 I66), informs of 88 old fees, and I I $\frac{3}{4}$ new, and 28 of the old had Nigel de Albigni enfeoffed "de dominio suo": this Nigel (his father), was one of those great men aggrandized by Hen. I., and the 60 fees (88 less 28) would seem to include parts of the estates of Robt. de Moubrai, and Robt. de Stuteville, escheats of Wm. II. and Hen. I. Dugdale quoting Vitalis states that Nigel de Albini married a second time in June II 8 , and that his heir Roger de Moubrai was within his age I I38, 3 Step., (citing Ailredus Rieval.); the Pipe Roll passing for 3 I Hen. I. makes it clear the said Nigel $\dagger$ was then deceased, hence all the 88 fees

* In D. B., i. 2506, the name Chenvin occurs as a tenant T. R. E., and 1086.

$\dagger$ In 1086, a Nigel de Albini's principal estates were in Nigel Beds-he also held in Bucks, Leic. and Warw., and had held d'Aubigni in Berks (D. B. 59b); Hen. de Albeyni of Cainho would $\underset{\text { Roger de }}{\text { and }}$ appear to have succeeded to all or parts of the above in Beds, Moubrai. Bucks, and Leic., whose son and heir (Dugdalc) Ro. in 1166 returns under Beds a carta of 25 fees of his Barony. In the Baronage of England the above Henry is stated to have been a younger son of Nigel (of the text), and a grantor (with the Lady Cicely, his wife) $t$. Hen. I. ; this however can scarcely be correct, as Rog. de Moubrai (his presumed elder brother) is allowed by Dugdale to have been a minor at the Battle of the Standard [3 Steph.] ; errors of course are inevitable in a so vast a work, whose author's painstaking labour would truly reflect the greatest credit on any age. Rog. de Moubrai in I1 66, returned as under Yorks, 88 old fces, and $11 \frac{3}{4}$ new ones", comprising 
FIVE TABLES OF KNIGHTS' FEES, Ir66- 1346.

\begin{tabular}{|c|c|c|c|c|c|c|c|c|c|}
\hline & \multicolumn{5}{|c|}{$\begin{array}{l}\text { I65-8, Barons Certificates } \\
\text { aNd Pite Roll. }\end{array}$} & \multirow{2}{*}{$\begin{array}{l}\text { I } 2 \text { Io-I2 } \\
\text { Inq., } \\
\text { Total. }\end{array}$} & \multirow{2}{*}{$\begin{array}{c}\text { 125.3.4 } \\
\text { Pipe-Roil } \\
38 \text { Hen.111., } \\
\text { Totals. }\end{array}$} & \multirow{2}{*}{$\begin{array}{c}b . \\
\text { I302 } \\
\text { Inq., } \\
\text { Total. }\end{array}$} & \multirow{2}{*}{$\begin{array}{l}* c . \\
\times 346 \\
\text { Inc.. } \\
\text { Total. }\end{array}$} \\
\hline & $\begin{array}{l}\text { Ren- } \\
\text { der. }\end{array}$ & "Ser-" & $\begin{array}{c}\text { Ex- } \\
\text { cess, } \\
\text { Old. }\end{array}$ & \begin{tabular}{|c|} 
Ex- \\
cess, \\
New.
\end{tabular} & Tutal. & & & & \\
\hline Beds & $98 \frac{3}{4}$ & $109 \frac{3}{4}$ & $\frac{7}{12}$ & $\cdots$ & I $10 \frac{1}{3}$ & $113 \frac{1}{2}$ & $18 I_{18}^{6}$ & $89^{\frac{k}{3}}$ & $89 \frac{1}{3}$ \\
\hline Berks & $137 \frac{1}{4}$ & 135! & $5 \frac{1}{2}$ & 2 & $1422^{3}$ & $36 \frac{1}{5}$ & 42 \% & III 1 & $116 \frac{1}{10}$ \\
\hline Bucks & I $52 \frac{11}{21}$ & I $55 \frac{19}{2}$ & 12 & $4 \frac{1}{4}$ & $172_{24}^{1}$ & $170 \frac{1}{2}$ & 8170 & $163 \frac{1}{5}$ & $I 8 I$ \\
\hline Cambs & $95 \frac{7}{2}$ & 96 & $16 \frac{2}{3}$ & $17 \frac{17}{2}$ & $130 \frac{3}{k}$ & $\sqrt{249}$ & $\sqrt{141 \frac{3}{4}}$ & $164 \frac{5}{8}$ & $165 \frac{1}{4}$ \\
\hline Cornwall & $215 \frac{1}{3}$ & $215 \frac{1}{3}$ & $\ldots$ & $\cdots$ & $215^{\frac{1}{3}}$ & $220 \frac{1}{4}$ & $\ldots$ & I6524 & $165^{3}$ \\
\hline Cum'land & $\ldots$ & $\ldots$ & .. & $\ldots$ & $\cdots$ & $3 \frac{1}{2}$ & $3 \frac{1}{2}$ & $8 \frac{3}{4}$ & $10 \frac{1}{2}$ \\
\hline Derby & $68 \frac{1}{2}$ & 60 & $8 \frac{1}{2}$ & $10 \frac{1}{3}$ & $78^{5}$ & $\sqrt{86 \frac{1}{2}}$ & $\sqrt{230^{17}}$ & $79 \frac{1}{1}$ & 79 \\
\hline Devon & $424 \frac{1}{2}$ & $44 I$ & $17_{4}^{3}$ & $10 \frac{1}{2}$ & $469 \frac{1}{4}$ & $43^{8} \frac{1}{4}$ & $420 \frac{1}{2}$ & $364 \frac{1}{2}$ & 412 \\
\hline Dorset & $113 \frac{1}{2}$ & II $4 \frac{1}{2}$ & $1 I_{12}^{7}$ & II & $137 \frac{1}{3}$ & $7423=$ & $\sqrt{4} \mathrm{II} \frac{1}{3}$ & 1160 & 127 \\
\hline Essex & $379 \frac{1}{3}$ & $320 \frac{1}{4}$ & 5912 & $30 \frac{1}{4}$ & $409 \frac{7}{2}$ & $2414 \frac{5}{8}$ & $\checkmark 679 \frac{5}{12}$ & $264 \frac{1}{20}$ & 267 \\
\hline$\overline{\text { Gloucester }}$ & $392 \frac{3}{4}$ & $392 \frac{9}{1}$ & $47_{6}^{5}$ & $20_{4}^{3}$ & $46 \times \frac{1}{3}$ & $\begin{array}{c}\text { Not } \\
\text { found }\end{array}$ & $408 \frac{7}{20}$ & 135 & I35 \\
\hline Hants & $137 \frac{1}{4}$ & I37! & $14 \frac{1}{2}$ & 2 & I $53_{4}^{3}$ & $\begin{array}{c}\text { Not } \\
\text { found }\end{array}$ & $142 \frac{1}{4}$ & $170_{3}^{2}$ & $170_{4}^{3}$ \\
\hline Heretord & $170^{\frac{1}{2}}$ & $171 \frac{1}{2}$ & $6 \frac{1}{2}$ & $14 \frac{1}{6}$ & $192_{6}^{1}$ & 203 & $2592^{7} 4$ & $83^{\frac{6}{5}}$ & $84 \frac{1}{16}$ \\
\hline Herts & 62 & 62 & $\ldots$ & $4 \frac{1}{2}$ & $66 \frac{1}{2}$ & $\begin{array}{c}\text { Incl. in } \\
\text { Essex }\end{array}$ & See Essex & $85+13$ & $94^{\frac{3}{4}}$ \\
\hline Hunts & 35 & 35 & $2_{4}^{3}$ & $2 \frac{9}{10}$ & $40 \frac{2}{3}$ & $\begin{array}{l}\text { Incl. in } \\
\text { Cambs }\end{array}$ & $\begin{array}{c}\text { See } \\
\text { Cambs }\end{array}$ & $43^{\frac{1}{8}}$ & $49 \frac{1}{8}$ \\
\hline Kent & $215^{3}$ & 193 & 244 & $77^{3}$ & $225 \frac{1}{2}$ & $224^{3}$ & 155 & 25920 & $266 \frac{1}{3}$ \\
\hline Lancashire & .. & $\because$ & $\cdots$ & $\cdots$ & $\cdots$ & 91 & $\cdots$ & $\ldots$ & $29 \frac{3}{4}$ \\
\hline Leicester & 33 & 33 & $\cdots$ & $4 \frac{1}{2}$ & $37 \frac{1}{2}$ & $221 \frac{1}{4}$ & $287^{33}$ & .. & 100 \\
\hline Lincs & 35 琼 & $364 \%$ & $5 I^{\frac{1}{2}}$ & $21^{3}$ & $43^{8 \frac{1}{7}}$ & $3^{12 \frac{1}{4}}$ & $392^{17}$ & 4423 & $428 \frac{1}{3}$ \\
\hline Middlesex & 35 & 35 & $26_{12}^{\frac{1}{2}}$ & $\ldots$ & 6112 & $36 \frac{1}{2}$ & $I_{2}^{\frac{1}{2}}$ & 15. & I9童 \\
\hline Norfolk & $33^{8} \frac{\mathrm{g}}{10}$ & $337 \frac{9}{10}$ & $2 \pi$ & $3^{8}$ & $397 \frac{1}{7}$ & $\sqrt{475}$ & 6465 & $450 \%$ & $45^{8}$ \\
\hline Northants & 126 & $128 \frac{1}{4}$ & $36^{\frac{6}{6}}$ & $2 \frac{1}{6}$ & $134 \frac{1}{4}$ & $122 \frac{1}{4}$ & $124 \frac{1}{4}$ & $\ldots$ & $222 \frac{1}{6}$ \\
\hline N'th'land & $77^{\frac{2}{3}}$ & $76_{3}^{2}$ & $2 \frac{1}{2}$ & $4 \frac{11}{12}$ & $84 \frac{1}{12}$ & 68 & [9r $\left.\frac{1}{2}\right]$ & $\because$ & $145^{1}$ \\
\hline Notts & $I_{4} I$ & $143^{\frac{1}{2}}$ & $\cdots$ & $4 \frac{1}{15}$ & $147 \frac{19}{30}$ & $\begin{array}{l}\text { Incl. in } \\
\text { Derby }\end{array}$ & See Derby & $163^{\frac{1}{6}}$ & $160 \frac{2}{3}$ \\
\hline Oxon & $56 \%$ & $56_{6}^{5}$ & $\cdots$ & $I_{21}^{11}$ & $58 \frac{2}{6}$ & $\begin{array}{c}\text { Not } \\
\text { found }\end{array}$ & $85 \frac{11}{20}$ & $\overline{168 \frac{3}{4}}$ & $168 \frac{3}{4}$ \\
\hline Rutland & $\cdots$ & $\therefore$ & $\ldots$ & $\cdots$ & & $7 \frac{1}{2}$ & $1 \frac{1}{2}$ & $25 \frac{2}{3}$ & $24 \frac{2}{3}$ \\
\hline Salop & $56 \%$ & $54 \frac{21}{30}$ & $\cdots$ & $4 \frac{3}{8}$ & $59 \frac{1}{7}$ & $97 \frac{1}{4}$ & $62 \%$ & . & $107 \frac{1}{7}$ \\
\hline Somerset & 253 & $253 \frac{3}{4}$ & $4 \frac{1}{2}$ & $15 \frac{1}{6}$ & $273 i^{5}$ & $\begin{array}{l}\text { Incl. in } \\
\text { Dorset }\end{array}$ & $\begin{array}{c}\text { See } \\
\text { Dorset }\end{array}$ & $281_{8}^{3}$ & 289 \\
\hline Staffs & 126 & 126 & $\cdots$ & $6 \frac{2}{3}$ & $132 \frac{2}{3}$ & $\begin{array}{l}\text { Not } \\
\text { found }\end{array}$ & 128 & . & $\begin{array}{c}\text { Un- } \\
\text { com- } \\
\text { puted }\end{array}$ \\
\hline Suftolk & $295 \frac{1}{6}$ & $297 \frac{1}{6}$ & 5 & $8 \frac{1}{4}$ & $3 \mathrm{IO}_{12}^{5}$ & $\begin{array}{l}\text { Incl. in } \\
\text { Norfolk }\end{array}$ & $\begin{array}{c}\text { See } \\
\text { Norfolk }\end{array}$ & $279 \frac{1}{8}$ & $28 \mathrm{I} \frac{1}{4}$ \\
\hline Surrey & 3 & 3 & $I$ & $\ldots$ & 4 & 24 & $9 \frac{5}{6}$ & $691^{2} 0$ & $73_{3}^{2}$ \\
\hline Sussex & $25 I_{2}^{\frac{1}{2}}$ & 248 & $7 \times 40$ & 14 & $269_{80}^{4}$ & $224^{\frac{3}{4}}$ & $276 \frac{1}{2}$ & $213 \frac{2}{3}$ & 235 \\
\hline Warwick & $124^{3}$ & $124 \frac{3}{4}$ & $\ldots$ & $7 \frac{1}{4}$ & 132 & $156 \frac{1}{2}$ & See Leic. & $\ldots$ & 87 \\
\hline West'land & $\ldots$ & .. & $\therefore$ & $\ldots$ & $\cdots$ & $\ldots$ & $\because$ & $\because$ & $7 \frac{2}{3}$ \\
\hline Wilts & $174^{\frac{4}{3}}$ & $174 \%$ & $10 \frac{1}{2}$ & $14 \frac{1}{10}$ & $199 \frac{1}{5}$ & $176 \frac{1}{1}$ & $174^{\frac{8}{4}}$ & 20748 & 227 \\
\hline Worcester & $62 \frac{3}{3}$ & $63 \frac{1}{2}$ & 9 & $7 \frac{4}{3}$ & $80_{10}^{3}$ & $248 \frac{1}{2}$ & 78 & 821 & 82 \\
\hline Yorks & 515 & -49532 & $79 \frac{1}{2}$ & $\overrightarrow{47 \hat{4}}$ & 62232 & $490_{3}^{1}$ & $441_{10}^{\frac{7}{10}}$ & $348 \frac{7}{3}$ & $394 \frac{2}{7}$ \\
\hline & $5,720_{8}^{7}$ & 5,656 & 4503 & $340 \frac{2}{5}$ & $6,446_{2}^{3}$ & $5,334 \frac{2}{5}$ & c. 5,959 & & c. 6,00 \\
\hline
\end{tabular}




\section{NOTES TO TABLES OF KNIGHTS' FEES.}

*a This was an aid to Knight Prince Edward, granted by Aids of the Prelates and Magnates, scilicet de singulis scutis que de nobis tenentur in capite $x l$ solidos tam de veteri feofamento quam de novo (Lnnc. Lay Subs. - J. A. C. Vincent-citing Cl. 37 Hen. III.), contrasted. but with 2 or 3 exceptions new feoffment is quite omitted in the returns, these for the more part being equivalent to the render of 1168 , that is, those fees alone for which the tenants were wont to respond for escuage, so that this column may be properly compared with the Ist one in the Table as regards the total. It should be understood that both in I 68 and I 253-4 the counties have a somewhat nominal significancefor a baron owning lands in divers shires may be returned under only one of them, and hence for any co. the result is likely to be both excessive and deficient, and the making a transcript from the Pipe Rolls of any particular shire does not of necessity answer to a list of its capital tenants by knt. service. There are several omissions in $1253-4$, amounting under I I entries to some 775 fees; viz., the co. of Cornwall $215 \frac{1}{3}$; portions of the fiefs of the Earldoms of Chester and

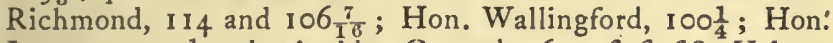
Lancaster, $72 \frac{1}{3}$; the Archbp. Canterb., 6o; fief of St. Valery, 50 less II ; Hon. B'stead, $22 \frac{1}{2} \frac{3}{0}$; and the fees late $W m . f$. Robert, Wm. Traci, and Rog. Buron, 29, 6, and 1o. Fiefs of less than Io ( 12 Hen. II.) have not been traced, but it may be assumed with probability that some new fees had been granted since that date (e.g., Hon. Knaresbro') ; Cornwall is not found, having been granted to Earl of same in I 5 Hen. III. (Dugdale) for 5 fees, who also held the Hon. of Wallingford (noted, but no payment nor return of fees): I 2 counties answer in pairs, and N'land and Rutland have been supplied from the Roll of 40 Hen. III. (aid to knt.)-counting en bloc the composite entries under Honors (those under Boulogne, and Peverels of Essex, and Notts are answered by tenants of same, and taken as 3 entries) the tenants yield some 439 names, which allowing for omissions may be taken as 6.450 , as against 300 in A.D. I I68. Neglecting the omissions, and taking the fees of $38 \mathrm{Hen}$. III. as 5959 in 439 entries, 9 tenants hold a full $\frac{1}{4}$ of them (15.72), and 29 over $\frac{1}{2}$ (3012), but the majority of tenements consist of small fees ( $\frac{1}{15}$ to 2 ), leaving 204 names for upwards of 2 (fees), but 74 of them holding more than 20 fees. The returns of $12 \mathrm{Hen}$. II. on the same basis (render) yicld 6339 fees $(5721+618$, as omissions here added) in 300 entries, of which I I tenants hold $\frac{1}{4}$ ( 1600$), 34$ a half (3204), 


\section{Domesday and Feudal Statistics}

and a minority (94) 2 fees and under ( 2 to $\frac{1}{4}$ ), leaving 206 holders of upwards of 2 , of which 121 and 40 hold 15 , and 50 fees and upwards respectively; it is not thought probable that there were many (if any) single capital fees T. R. W. as will appear in the sequel. These rough analyses (correct, however, for practical purposes) of $12 \mathrm{Hen}$. II. to $38 \mathrm{Hen}$. III. show a natural increase of tenants due in the main to partition thro' heiresses; after the Statute 18 Ed. I. (Quia Emptores) further increase should occur, but (if I err not) there are no existing records from which complete lists of contemporaneous holders of the Crown can be furnished.

Aid of 1302 .

${ }^{*} b$ Fourteen of these entries have been already printed in Lancs. Lay Subs. (J. A. C. Vincent), but those in the Table (save Wilts), are from Enrolled Exch. alcs $L . \tau$. R. No. 3, the reference seemingly given for the I4 (ut sup.) being now changed (I am informed) to Subs. L. T.R. No. 2, which is less complete than Enrolled, etc. (ut. sup.), but considerably more so than the list in Lancs. Lay Subs.; with regard to which (p. 248 ibid.) Surrey is given $\oint_{0} 1642$ s. Id. (i.e. $82 \frac{1}{2}$ fees), a reading which neither of the above originals assign it (either reads II $_{3} 98 \mathrm{~s}$. od.), but both refer to Worcester, which the author of above vol. refrains to mention, nor were N. R., and E. R. of co. Yorks assessed as such (p. 248, ibid.) but portion of the former was taken with the latter, and balance of the former separately, as the details in the Exch. Enr. a/cs (ut sup.) amply demonstrate.

Total of ${ }^{*} C$ Sum of all the great fees in England (save Staffs) Knights'

Fees,

t. Ed. III. by contempurary Scribe. $5,831 \frac{3}{4}+\frac{1}{8}$ plus $2 \mathrm{~s}$. $7 \frac{1}{2} \mathrm{~d}$. more in total $=\oint_{0} \mathrm{I} 1,663 \mathrm{I}$ s. $7 \frac{1}{2} \mathrm{~d}$. at 62 per fee ; small fees of Moreton in Somerset, Dorset, and Bucks, $60 \frac{1}{4}+\frac{1}{13}=£ 808$ s. $8 \frac{1}{2}$ d. at 2 marcs per fee; small fees of Moreton in Devon, $61 \frac{1}{12}=\oint_{0} 67 \mathrm{~s}$. $0 \frac{1}{2} \mathrm{~d}$. at $25 \mathrm{~s}$. per fee : total sum, EII,820 I3s. $4 \frac{1}{2} d .0$ The writer being unsatisfied with the incomplete returns in the Book of Aids for this Auxilium instructed Mr. N. J. Hone, to search for it in Enrolled a/cs of the Exch., where it was found in No. 3 ; the record certainly deserves publication verbatim et litteratim. It must be explained (the original MS. it is believed is a triumph of addition) that the writer for reasons of expediency has used slight license with Mr. Hone's figures (who must not therefore be accused of lack of accuracy); thus Hereford is returned as fourscore and four fees and the sixteenth part, and the half of the forty-eighth part of a fee, whereas $84 \frac{1}{6}$ fees appear in the table, and similar slender deviations (never $\frac{1}{4}$ fee) occur in same. 
are proveably old ones. Now the Moubrai fee ${ }_{\text {Fee. }}^{\text {Mobrai }}$ (Hen. II.-III.) is always rendered between 88 and 89 fees (usually $88 \frac{1}{4}$ fees), and in the Inquisitions I2-I 4 John (pp. 469-574, L. R., v. ii.) it is curious to observe $60 \frac{1}{4}$ fees (the $\frac{1}{4}$ fee held of the Archbp. of York) are given by the Yorks sheriff, and just 28 by those of Lincs, Leicester, Cambridge, Hunts, and Warwick; Dugdale (quoting ancient authors) informs of the additions of the Northern Baronies of Moubrai and Stutteville t. Hen. I., and these would presumably pass with all the Knights those lords had enfeoffed. The Patent Roll of 20 Hen. VI. cites a grant of Massamshire from Earl Alan to Rog. de Moubrai, by the same service as his father Nigel de Albini held it, to wit I fee, and then proceeds to give the boundaries of his grant, which method may have run parallel with subinfeudation by hides and carucates, as where $\mathrm{I}_{4}$ car. make a fee (Skipton Fee, L. R., I I66).

Few better estimates have been made than Pearson's (cited in " Feudal England," p. 293) viz. 6,400 Knights' fees of 5 Hides each, stipulating for an average, and not a uniform 5-6 Hides; as an eclectic table is of doubtful value, the following Method of explanations of the II66-8 tenures are givensuch entries in the Red Book (Barons' Cartæ.) as computing fees. are of date posterior to t. Hen. II. are omitted,

comprising lands (I think) in Essex, Lincs, N'ants, Leics, Notts, Warwick, and Yorks (in the 4 last named also in Pipe Roll 3 I Hen. I.); Nigel (his father), and Wm. de Albini (Pincerna), appear to have been younger sons of Henry of Cainho (ut sup.), who presumably was himself the son or brother of Nigel the Domesday tenant (vide D. B.; Ord. Vit., and Chron. Abingdon). 


\section{Domesday and Feudal Statistics}

whilst some in a hand later than the original are retained (e.g. nearly all the Yorks entries by the Sheriff) as of those who had not sent Charters, with further additions from the I 4 Hen. II. Pipe Roll of fees military, but not from later ones, excepting the Abbot of Malmesbury (required to complete the military church tenants) who appears neither in the returns of II66 nor I 168. By this method some 700-800 fees are lost, thus the Farl of Richmond 64, the balance between 140 (the least probable no.) and 76 named in the L. R. I 166 returns, the Honour of Boulogne, say I 13 , Earl of Leicester say I $211_{10}^{7}$, the Honour of the Constable in Essex, say 57, part of the Earl of Chester's fees, say I I 8, Bernard de St. Valery, say 50, Simon Crevequer I $3 \frac{1}{2}$, with Peverel of Dover $8 \frac{1}{2}$, and Hon. Lancaster $72 \frac{1}{3}$ ** The service due (including escheats) in I 166-8 there can be little doubt exceeded 6,000 fees, but by how much is difficult to estimate, as the largest tenements are those where most uncertainty prevails-to state the number as under 7,000 may be probable, but Explana- scarcely proveable. The Ist col. of the table 5 column Table, $t$. Hen. II. gives the render of account in Pipe Roll 14 Hen II., with allowances for omitted returns from later Rolls (thus the whole of the Salop tenants sending charters are wanting $\mathrm{I}_{4} \mathrm{Hen}$. II.); the 2nd the services due where stated, and where not the "render" which method is erroneous for large tenements; the $3^{\text {d }}$ the excess of old feoffment over service, by equating latter with "render"

* The fees of Earl Hunts. and the complement of the Chester fief (both unknown to writer) are here omitted. 
where unstated, the $4^{\text {th }}$ the excess of new feoffment on the same plan, and the $5^{\text {th }}$ the total, probably short of the real one on the ground of incomplete returns from the larger tenements, where as a rule nothing is assigned to the dominicum. The ist and 2 nd column would be practically equal, if deductions were made from the former of excess by tenements in the hands of a custos, and certain exceptional cases (noted in the sequel) where the render is excessive and corrected in future returns. There are some 5 I cases of fees from 10-75, where the service seems to be stated; made up as under, using $\mathrm{O}=$ Old, $\mathrm{N}=\mathrm{New}, \mathrm{S} . \mathrm{D}=$ Super Dominicum

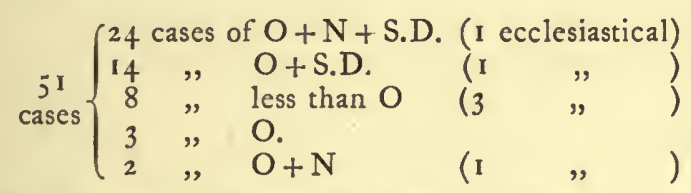

Composition of known "Service."

and 76 cases of fees of Lay Tenants, of service unknown but presumably exceeding 10 , as under

$$
\begin{aligned}
& 4^{2} \text { cases of } \mathrm{O} . \quad 4 \text { cases } \mathrm{O}+\mathrm{N}+\mathrm{S} \text {.D. } \\
& 15 \text { " by Sheriff } 4, \mathrm{O}+\mathrm{N} \\
& 8 \text { ", of O+S.D. } 3 \text { ", less than O } \\
& \text { Total, } 76 \text { cases. }
\end{aligned}
$$

Composition of unknown " Service."

Thus it plainly appears in the known cases that Remarks $\mathrm{O}+\mathrm{N}+\mathrm{S} . \mathrm{D}$. is the most frequent service ; whereas in the render of the unknown lay fees, $\mathrm{O}$ occurs very commonly; here the ecclesiastical fees are omitted, their conditions not being applicable to lay ones. For example the Honor of Totnes returns 49 old, $19 \frac{4}{15}$ new, and $6 \frac{11}{15}$ s. d., which amounts to 75 fees, the probable tho' unstated 


\section{Domesday and Feudal Statistics}

service; whereas the render is $55 \frac{7}{8}$ fees, which being palpably deficient, a debit of $19 \frac{1}{8}$ is entered against the tenant on the Pipe Roll (nevertheless $55 \frac{7}{8}$ fees or thereabouts becomes the basis of returns of Ric. I. to Hen. III.) ; but the Earl of Glos'ter whose service is unascertainable renders $26 \mathrm{I} \frac{1}{2}$ fees, whereas his charters inform of some $258 \frac{1}{2}$ old, and $13 \frac{1}{2}$ new in Glos'ter, besides 23 fees in Kent, which would be lightly rated at 300 (the Honor reputed to have been granted to Ro. Fitz Hamo by Wm. II.); also the Earl of Clare rendering 142 , and debited with $7 \frac{3}{4}$ new, informs by charter of a similar number of fees, making no statement either as to service or a balance on the dominicum, and it may be noted the Exchequer seems not to have material available for completing a defective return. Total The total of tenants is about 300 , and with tenants (ut some I I exceptions (I think) the render of de coronâ),

by Knight Service: render the usual basis It Hen. II. (or a later render where not returned in that Roll) became the basis of assessment for Ric. I. to Hen. III. throughout England; and in Yorkshire (and presumably for all England) for the reigns of Hen. III. and Ed. I. (as is proved by the aids to marry and Knight 29 and 38 Hen. III., and the Welsh Scutages of 42 Hen. III., 7 and I4 Ed. I. see Pipe Rolls); by the render is meant the reddit compotum only, not including the additional amount now and then debited to the tenant t. Hen. 'II. Of these I I exceptional renders 5 were adjusted by I 8 Hen. II. (the Irish scutage), and 4 more by 2. Ric. I., 


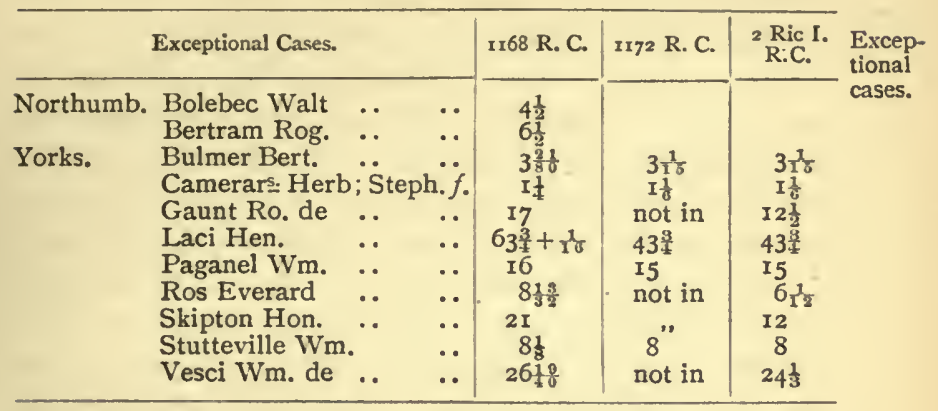

and of the rest, the fee of Bolebec Walt. has avowedly a service of 5 (Charter I I66) and is so given in Swereford's extracts from the Pipe Roll of 4 John, also p. 392 Testa de N. in the inquisitions of I2I2-I2I4, and not only is Rog. Bertram's service stated as 5 (Charter I I 66) but is so returned in the above named inquest (p. 392, T. de N.).

Some 146 Charters state or practically state the "Render" service, which in 103 cases agrees with the render, "Service." and in 27 disagrees (the remainder not being found on the I 4 Hen. II. Pipe Roll), but this excess is largely composed of very small fees, and this to such an extent that there are about 800 fees agreeing with the r. c. and the same number disagreeing; the majority of the important barons very prudently declining any information either as to their service or the debt on their "dominicum," are thus practically at their own assessment. Certainly in the reign of Hen. II. there are additional charges on new feoffment (much of which was due to the Crown), the relative payment or non-pay- 


\section{$5^{8}$ Domesday and Feudal Statistics}

New feoffment.

ment of which would require to be sought out, but the attempt to enforce even the new that was owing (where not included in the render of I 4 Hen. II.) seems to have been abandoned in later reigns (Ric. I.-Ed. I.). The consequence of the above probably was that there was much loss of service due, in addition to considerable difficulty in collecting the scutage on the basis of the I 4 Hen. II. render, and doubtless numerous bad debts ; Swereford has given enough extracts from the Pipe Rolls of Ric. I. and John (pp. 70-184 V. i. L. R. Rolls Ser.) to trace the "services" of fees, and there are the Inquisitions of I 2 IO- 12 I 2 (pp. 469-574 ibid.), in addition to the already named Pipe Rolls of Hen. III. and Ed. I. Of far

Excess of more importance than the supposed increase of old feoffment, on ecclesiastical fees, service from I I68, and permanent change of assessment (p. 286, "Feudal England") was the not usually attempt (likewise unsuccessful) of the Crown to paid. make the church fees pay on excess of old feoffment ; in I 5 Hen. III. (Brady's "Hist. Eng." V. i., App. p. 42, citing Pat. Rot. I 5 H. III.) the prelates conceded to the King 40s. per fee, on those fees they were wont to answer for to military service, but were permitted to have service of all their fees for themselves at the like rate; again I 9 Hen. III. (Brady ut supra, pp. 43 and 44, citing Close Roll) an aid had been conceded on church and lay fees of both old and new (to marry the King's sister), the collections, etc., for which appear in the Testa de N.; and that the concession of $x_{9}$ Hen. III. was exceptional is plainly brought out by Pat. 20 H. III. m. 8 (cited by Madox) to 


\section{Feudal Statistics}

wit, that it was from all the ecclesiastical fees, as well those of which response is made to scutage, as of others retained to the tenants' own use, the grant not to be drawn into a precedent.

In $27 \mathrm{Hen}$. III. the lay tenants who did not Aid to join the Gascony expedition fined and conceded marry, scutage (voluntarily) of both old and new, but the Gascony Bishops conceded 4Os. per fee on their service, and 1242. in return were allowed for themselves, to take 4Os. from all their fees (Mich. Comm., 27 Hen. III., as cited by Madox); the inquisitions and collections (from the prelates) may be found in the Testa de N.; ; where the 19 and 26 Hen. III. items are the chief contents as regards feudal service alone; the inquests of Fo hn's reign being frequently as to the rights of the Crown and subtractions of service (with tenure by knight service, serjeanty, and socage often occurring together), and no systematic returns about old and new feoffment. The difference between the aid

* It is to be hoped, in case of a new issue of the Testa de Testa de Nevill, Minerva will temporarily endow its editor with so Nevill. much of discretion as to enable him to distinguish, say, between an undated inquisition of the reign of John and Hen. III.; see the note p. 733 , vol. ii., Red Book Rolls Series, placing the extent of Nigel de Moubrai's fee (probably $15-25$ Hen. III. during the heir's minority) as later than the inquisitions of the Gascony Scutage (pp. 363 and $366, T$. de N.) of circt $26 \mathrm{Hen}$. III. Fither these inquests in Yorks are fragmentary or incomplete returns; the Moubrai fee proves this, for the inquisition (p. 733 as above) is considerably fuller than that in the Testa for this county. With reference to the date of the Testa returns (pp. 363 and $366)$, both the form of the record and the names of the tenarits should have been sufficiently significant. 


\section{Domesday and Feudal Statistics}

to marry I9 Hen. III., the Gascony escuage $26 \mathrm{Hen}$. III. and an ordinary aid (as 29 and 38 Hen. III.) and escuage (as 42 Hen. III.) was that in the two former payment was made on all fees or all that could be found, in the latter on those only recognised in the renders of the tenants' antecessors in 14 Hen. II. ; what old and new feoffment meant 19 and 26 Hen. III. is not significant, and was perhaps differently understood by divers Northum- tenants, but in the 1242 Inquisitions Northumberquiland In- land (p. $38 \mathrm{I}$, etc., Testa de N.) old feoffments are 26 Hen.III. those made in and before Hen. II., new ones from t. John, which is to be seen by reference to the Inquisitions of I 2-I 3 John (T. de N., pp. 392-3, under heading T. de N.), which latter are abstracted in the L. R. (pp. 562-5, v. ii. Rolls Series). There is not the least witness of general inquisitions of old and new feoffment prior to 1242 (saving the case of the aid to marry ig Hen. III.) Evidence where the evidence seems to have consisted partly Nevill.
Nesta of charters of the magnates (referred to in the sequel), and partly of inquiries made by the Sheriff ; as examples the Bp. Durham (service 10) pays on I 50, 19 Hen. III., is noted for 10, 26 Hen. III. ; the Bp. Hereford pays on 18, I9 Hen. III. (service 15 ), and the Archbp. of York is noted for 20 (his service) 26 Hen. III.; but the monastic houses on both occasions (in theory) pay on all their fees; thus I9 Hen. III. Abbotsbury (I) pays on $3 \frac{3}{4}$, Cerne (2) on 5, Pershore (2) on 5, and also in 26 Hen. III., when Ramsey (4) pays on $33 \frac{1}{3}$, Winchcombe (2) on 5, and Malmesbury (3) on $6 \frac{2}{3}$, but perhaps sometimes these were compositions. 


\section{Feudal Statistics}

Returning to I I66-8, there were I think nearly 500 fees newly created (I I 35-I I 66) of which

About 2 IO debited on the I4 Hen. II. Pipe Roll.

Due to the Crown $\quad \ldots \quad \ldots \quad \ldots \quad 45$ fees

By custos

Not due, but claimed

Doubtful

... $\quad \ldots \quad 1 \frac{1}{2} \quad$

... $\quad \cdots \quad 35 \quad "$

... ... 128 ,

Extent of so called exactions of " new feoffment."

About 273 not debited on the I4 Hen. II. Pipe Roll.

$\begin{array}{llllll}\text { Of which, no returns } & \ldots & \ldots & \ldots & 15 & \text { fees. }\end{array}$

Included in render $\quad \ldots \quad \ldots \quad \ldots \quad 96 \frac{1}{2} \quad$,

$\begin{array}{llllll}\text { Not due nor charged } & \ldots & \ldots & \ldots & 78 & \end{array}$

Doubtful, not charged ... $\quad \ldots \quad \ldots \quad 70$ ",

Due, but not charged $\ldots . . \quad \ldots \quad \ldots .13 \frac{1}{3} "$

so that far from annexing all new feoffment, the Exchequer did not even always demand payment when due. Some new fees are included in the render, and the majority of doubtful cases appear to be due, and after all the total demands for further payments, owing, doubtful, or otherwise, were but on a minimum of fees, i.e., 210 out of some 6,000-7,000: the following examples are of fees due, not charged.

\begin{tabular}{|c|c|c|c|c|c|c|c|}
\hline & & $\begin{array}{l}\text { Ser- } \\
\text { vice. }\end{array}$ & Old. & New. & S. D. & Paid. & Debited. \\
\hline Pinkeni Gilb. & .. & I 5 & $\mathrm{II} \frac{1}{2}$ & $I_{\frac{1}{2}}$ & 2 & 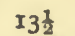 & Nichil \\
\hline Windlesores $\mathrm{Wm}$. & & 20 & $16 \frac{1}{2}$ & $I \frac{8}{6}$ & I & $18 \frac{13}{80}$ & " \\
\hline Wahull Walt. & . & 30 & $27 \frac{7}{12}$ & I t & $I_{\frac{1}{2}}$ & 27 & ". \\
\hline Foliot Ro. . . & . & $I_{5}$ & I3妾 & $3 \frac{1}{4}$ & - & I3 3 & " \\
\hline Cormeilles Ric. & .. & Io & 6 & I & 3 & 9 & " \\
\hline Chauz Ro... & .. & I5 & $12 \frac{1}{2}$ & $2 \frac{1}{2}$ & $\frac{1}{2}$ & $12 \frac{1}{2}$ & .. \\
\hline Fossard Wm. & .. & $33 \frac{1}{2}$ & 27 & I & $5 \frac{1}{2}$ & $3 I \frac{1}{2}$ & " \\
\hline
\end{tabular}

The chief features of the I4 Hen. II. Pipe Roll seem to be the presumptive escape, of many of the 


\section{Domesday and Feudal Statistics}

magnates, from a payment adequate to their prob-

Evidence able service, and the attempt to tax the church on of Pipe

Roll, all her fees of old feoffment; few lay barons of ${ }_{14}$ Hen. II. known service of $\mathrm{rO}$ fees and upwards had any excess of old; these cases are all in Essex, viz., Essex Galf. Comes, Mountfichet Wm., and Walt. $f$. Ro. (who all fall back on what their men tell them, and whose charters were perhaps indebted to the ingenuity of the same scribe), with the possible exception of Earl Ferrars ; but on the other hand excess of old was quite common in church fees, which (if I have observed rightly) are somewhat as under

Total.

Summary Service. Archbps, and Bps, 46I $\frac{1}{2}$ Monastic Houses $294 \frac{3}{5} \quad 75^{6} \frac{1}{10}$ of Church Total Fees. " "

\begin{tabular}{|c|c|c|c|c|c|c|}
\hline \multirow[b]{2}{*}{$\begin{array}{l}\text { Bps. etc. } \\
\text { Mon. Houses }\end{array}$} & \multicolumn{4}{|c|}{ Service. } & \multicolumn{2}{|c|}{ Excess. } \\
\hline & 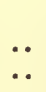 & $\begin{array}{l}\text { Óld. } \\
45^{1} \\
284^{\frac{1}{1}} \\
\end{array}$ & $\begin{array}{c}\text { New. } \\
3 \frac{1}{2} \\
\frac{1}{2}\end{array}$ & $\begin{array}{c}S . D . \\
6 \frac{3}{4} \\
9 \frac{1}{6}\end{array}$ & $\begin{array}{l}\text { Old. } \\
240 \frac{3}{4} \\
45 \frac{7}{16}\end{array}$ & $\begin{array}{c}N e w . \\
4 I \frac{1}{2} \\
3 \frac{1}{3}\end{array}$ \\
\hline & & $736 \frac{11}{60}$ & 4 & $15 \frac{1}{1} \frac{1}{2}$ & $286 \frac{13}{6}$ & $44^{\frac{5}{6}}$ \\
\hline
\end{tabular}

Ecclesiastics as a rule " render" their services, and are debited with excess old, but not excess new, which latter just in a few cases is included in the r. c., so that of some 263 cases of excess old debited on the 14 Hen. II. Pipe Roll almost all belong to the Church; this is a less total than 286 (above) but the Archbp. of Canterbury's fee (paid by a custos) is included in the render, and the Abbot of Peterboro' is not charged (with his excess),-in addition slight deficiencies in the charters render exact figures (when collating with the I4 Hen. II. Pipe Roll) impracticable. Of the 
balance between $450 \frac{3}{8}$ fees (total of $3^{\text {d }}$ col. being excess of old) and 263 (Pipe Roll), Wm. de Romara is charged with $9 \frac{1}{2}$ fees relaxed, which with the excess of render over service by certain lay tenants accounts for about 80 fees; of the remainder most of 84 fees were probably due tho' not rendered (service unknown), and with the cases of Canterbury and Peterboro' account for the total. Thus Nigel de Luvetot (Hunts) probably owes the I $2 \frac{3}{4}$ fees he names in his Charter, tho' he escapes by paying on IO, hence he must be supposed to have excess of old (service unstated), so that I presume about 84 of the $450 \frac{3}{8}$ excess of old were due to the Crown-taking the Church fees to have been correctly assessed by their renders. Perhaps amongst the curiosities of the Exchequer Unremight be found a case of a Bishop or Abbot paying liabilities, on a fee he did not recognise, but saving by a and custos it has not been the writer's good fortune to discover an example thereof-thus in Pipe Roll of eccleI Ric. I. (I 189) the Archbp. of York and Bp. of Durham still owe their contributions (of unrecognised fees) for the aid to marry the daughter of Hen. II. (I I 68). Pearson's table of Valets (Hist. Eng., pp. 665-9) for 2 I Southern Counties estimates the home ecclesiastics as being lords of about $\frac{3}{10}$ of the land in 1086 ; and of the total fees of I I 66 the Church possess $\frac{1}{6}$ to $\frac{1}{7}$, so that the presumption lies, that tho' in proportion to their service the religious had far more Knights than the lay barons, their "dominicum" was still in greater comparative excess.

In the 40,000 acres of the Liberty of Ripon, 


\section{Domesday and Feudal Statistics}

"Liberty, the Archbp. of York had (3 I Ed. I. and $20 \mathrm{Ed}$. III.) not quite 3 fees, which I suppose in the language of the Exchequer (still current) would be some 12 or I 5 Hides of 160 acres each, or at most 36 carucates of I 20 ac. (each); it is very evident the ecclesiastics were lightly rated, which perhaps explains their exemplary fines or promises when the King was going on an expedition. As already noted the second col. in the Table termed Inade- "Service" is erroneous, for the Render is not likely Col.2, to equal same in the larger unascertained fees, as Table I. there is no reason why in these the old feoffment should be the total due, when $\mathrm{S}=\mathrm{O}+\mathrm{N}+\mathrm{S}$. D is the commoner equation. Finding therefore that in known fees with a service of 1,232 (taking the 45 lay cases from previous table of 5 I known) there are some 1,070 of old, the "service" from unknown fees may be gauged roughly from the old feoffment : of the 76 cases named before, I 5 are returned by the Sheriff (and hence omitted), leaving some 2,653 fees of old, which it is presumed might be answerable for a service of 3,055 fees, and the difference 402 is a supposed balance to bring the estimated service more in line with that of the known fees, enabling subject to correction the underwritten table, which is thought to be low rather than high :

"Service," as shown in 2 nd col. ... $\quad \ldots \quad 5,656$

$\begin{array}{lllll}\text { Deficiency (estimated) } & \ldots & \ldots & \ldots & 402\end{array}$

$\begin{array}{llllll}\text { Estimate of } & \text { *Omissions (see list) } & \ldots & \ldots & \ldots & 618 \\ \text { "Service," } & & & & \end{array}$ Ir66.

Service $\quad \ldots \quad \ldots \quad \overline{6,676}$ fees

*Vide p. 54, and note pointing out what fees are still uncomputed in list of omissions (6 18$)$. 
Making the convenient assumption of 6,756 fees of which the Church held 756 and the lay Barons 6000 , and supposing $9,000,000$ acres held by the former, and I 5 millions by the latter, a Knight's fee $\dagger$ as against the King, would then have a scope of some 12,000 acres if ecclesiastical, and 2,500 acres it lav: in addition to the above (to estimate additional fees beyond service) there would have to be added such excess of old and new feoffment as has Estimate of acres in Church and Lay not been calculated in the adjustment (402), which (if I have not erred) would be somewhat as under:

$\begin{array}{lccccr}\text { Fees, answered by the Sheriff } & \ldots & \ldots & 745 \\ \text { Old feoffment } & \ldots & \ldots & \ldots & \ldots & 4,903 \\ \text { New feoffment } & \ldots & \ldots & \ldots & \ldots & 483 \\ \text { Super dominicum }\left(108 \frac{1}{2}+315 \frac{1}{2}\right)= & \ldots & 424 \\ \text { Omissions (see list) } & \ldots & \ldots & \ldots & 618\end{array}$

$$
\text { Total } \quad \ldots \quad \ldots \quad 7,173 \text { fees* }
$$

Estimate of Total Fees.

the "deficiency" (402) of the former table being found amongst the new, and s.d. in the above; whilst the omissions and Sheriffs' estimates do not permit of being further specified. Perhaps one might say the lay Barons had some 32,000 Domesday Hides plus 2,000-3,000 imaginary carucatest in Durham and Northumberland, which would furnish nearly 6 Hides per Fee as against the King, of a scope of Estimate of 430 acres each, or somewhat approaching to 400 ac. Hides in if allowance be made for land which never was

+ It is not of course meant to be conveyed that an entirc fee comprised nothing but military tenants; nevertheless the tenants in socage, and all the acres of land on a feudal lord's estate may from.one point of view be regarded as portion of his fee, and therefore of his service ; and thus in defence towards the king.

* Vide note, p. 54; hence total more than 7173 .

$\ddagger$ There is no intention to state the non-existence of carucates here, in and prior to 1086, vide Hist. St. Cuthbert. 


\section{Domesday and Feudal Statistics}

hided, and "carúcates". in hidated counties : these $400-430$ acres might by a convenient Exchequer fiction be reckoned as $\mathrm{I} 20-160 \mathrm{ac}$. of lucrable land. Taking characteristic examples from the II66 Certificates

Charac-

teristic

\begin{tabular}{|c|c|c|c|c|c|c|c|}
\hline 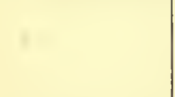 & : & $\dot{0}$ & 离 & $\stackrel{\dot{\theta}}{\dot{\Omega}}$ & 这 & ڤัँّัँ & 造 \\
\hline $\begin{array}{c}\text { Ecclesiastical } \\
\text { Fee. }\end{array}$ & & & & & & & \\
\hline $\begin{array}{c}\text { Bp. Lincoln } \\
\text { Lay Fees } \\
\text { (known). }\end{array}$ & 60 & 102 & $2^{\circ}$ & 一 & 60 & 42 old & \\
\hline $\begin{array}{l}\text { Hamo f. } \\
\text { Meinfelin }\end{array}$ & I5 & $I_{1}^{7}$ & $1 \frac{9}{10}$ & $\begin{array}{c}\text { the } \\
\text { balance }\end{array}$ & I5 & quit & \\
\hline Wahull Walt & 30 & $271^{7}$ & $I_{\frac{1}{2}}$ & $I_{2}^{\frac{1}{2}}$ & 27 & " & \\
\hline $\begin{array}{l}\text { Scalars } \\
\text { Steph. }\end{array}$ & I5 & Io & 一 & 5 & I5 & " & \\
\hline Ro. f. Wm. & 30 & $26 \frac{1}{2}$ & I & $2 \frac{1}{2}$ & 29 & I new & \\
\hline $\begin{array}{l}\text { Beauchamp, } \\
\text { Wm. }\end{array}$ & 7 & 16 & 一 & - & $\begin{array}{l}\text { not } \\
\text { found }\end{array}$ & $\begin{array}{l}\text { not } \\
\text { found }\end{array}$ & $\begin{array}{l}\text { In later re- } \\
\text { cords quit } \\
\text { for } 7 ; \text { an } \\
\text { u n us ual } \\
\text { case }\end{array}$ \\
\hline $\begin{array}{l}\text { Pagnel Ger- } \\
\text { vase }\end{array}$ & 50 & 50 & $5 \frac{2}{3}$ & - & 50 & quit & \\
\hline Foliot Ro. & I5 & I3䍃 & $3 \frac{1}{4}$ & - & I $3 \frac{3}{4}$ & " & \\
\hline $\begin{array}{c}\text { Lay Fees } \\
\text { (unknown): }\end{array}$ & & . & & & & & \\
\hline $\begin{array}{l}\text { Glos'ter Earl } \\
\text { of }\end{array}$ & - & $\begin{array}{r}258 \frac{1}{2} \\
+22 \frac{5}{6}\end{array}$ & $13 \frac{1}{2}$ & 一 & $-26 I \frac{1}{2}$ & quit & \\
\hline $\begin{array}{l}\text { Lascy Hugh } \\
\text { de }\end{array}$ & - & $54 \frac{1}{4}$ & $5 \frac{1}{2}$ & - & $5^{1 \frac{1}{4}}$ & " & \\
\hline $\begin{array}{l}\text { Reginald } \\
\text { Earl }\end{array}$ & - & & $5 \frac{1}{3}$ fees & & $2 I 5 \frac{1}{3}$ & $"$ & \\
\hline Hugh Earl & - & $12 I$ & $35 \frac{1}{2}$ & 一 & $125 \frac{1}{4}$ & $37 \frac{1}{2}$ & \\
\hline $\begin{array}{l}\text { Richmond } \\
\text { Earl }\end{array}$ & - & - & - & - & 50 & quit & $\begin{array}{l}\text { In Yorks } \\
\text { by Sheriff }\end{array}$ \\
\hline
\end{tabular}

In a return (pp. 26-7) in Gale's Honor of Richmond purporting (see Observations) to be of Hen. II., $68 \frac{1}{2}$ knights' fees are noted for Richmond- 


\section{Feudal Statistics}

shire (service 50); and. altho" the Redvers fee answered (I4 Hen. II. Pipe Roll) for but 89 fees, it avowedly contained over 100 (20 Hen. II. Pipe Roll); the above table shows somewhat the easy assessment of such important tenants as make indefinite returns. It may be suggested that in his charter a tenant now and then states his new feoffment within his statement as to $s_{0} d_{\text {. }}$; but as Super do.

a whole the certificates demonstrate this term (s.d.) to be used for land in the lord's hands in I 66 : Lamb. de Scoteni informs of a service of 10 , and has 5 fees of old, and $5 . s . d$., remarking that he has $\frac{3}{4}$ new, enfeoffed "ex illo dominio," and renders ro, but is debited with $\frac{3}{4}$ new, but probably his charter should be read as service 10, old 5 , new $\frac{3}{4}$, and s.d. 5 less $\frac{3}{4}$. Again Rad. de Worcester states his service to be $I$, and that he has enfeoffed $\frac{41}{42}$ of his few of new, the balance being s. d.; accordingly he renders $\mathrm{I}$, but is debited with $\frac{41}{42}$ new ; taking a line from all the certificates together demonstrates that usually the addition of old, new, and s. d. determines the service. The total entries are about 300 , not including the tenants of the 618 fees given under omissions, but the former number contains a few double entries; of this total 26I statistics of are lay, and 39 church fees. There are in all 125 Fees. cases of fees less than 5, and 155 less than 10, leaving 145 of 10 and upwards; of known fees from $10-75$ are 5 I cases, of which, I think, some ro cases with fractional dimensions, the remaining $4 \mathrm{I}$ being by service $10, \mathrm{I} 5,20,25$, $30,35,40,50,60$ and 75 ; where the service is unstated (for large fees) there is little uniformity, probably pointing to a defective render, and 


\section{8}

Domesday and. Feudal Statistics

further, cases of subsequent addition (known service) may have disturbed round figures, as in the case of Hen. de Lacy (Yorks) whose service (if I have observed rightly) should be read as 60 less 20 plus $3 \frac{3}{4}$.

The Computation of the Service of the Lay Tenants is entirely based on their own statements, which are scarcely likely to have exaggerated the

Capital tenants, xo86 and Ix66.

Inquisitions t. John.

Later Inquisitions. debt, and it may be called to mind that in 1086 (D. B.) were some 1400 tenants in capite (Ellis), of which it seems unlikely that 300 (if so many), were capital tenants of the Crown by Knight service.

The returns in the Table for $1210-12$, are of somewhat doubtful accuracy; the totals for I I 66-8 and 1346 have been considerably laboured, but that of the former date quickly run up; the inquisitions of King John give lists of tenants of whose services the sheriff is ignorant, and are otherwise incomplete, etc., for example 200 fees may be subtracted from Worcestershire (p. 567, V. ii. L. R. Rolls Series), as Walter Beauchamp is there given 207 fees instead of the correct 7, (see T. de N. p. 43).

The method of raising scutage and aid (T. de N.) temp. Hen. III. from all fees has already been referred to, which is repeated in the reigns of Ed. I., Ed. II. and Ed. III. for both purposes; from whence the valuable topographical inquisitions of Kirkby's Quest and Knights' Fees (Ed. I.), the Book of Aids (Ed. III.), and of Knights' Fees 6 Hen. VI.; the Crown seemed in constant alarm lest lack of service should occur and it is not 
surprising to find that England contained little more than 6,000 fees in I 346 . These I suppose Inquisiwere all that the jurors could or would find, and ${ }_{1346}^{\text {tions }}$. consisted of old and new without distinction; whether most of the fees which had formerly been returned as "super dominicum" were discovered is not quite so clear. Again deductions should be made from the total, as presumably there would be cases sinilar to those of the Abbots of Fountains, Furness, etc., who successfully (I think) disputed their indebtedness on some of the fees they were charged with. The aid to marry Blanche daughter of Hen. IV. is set forth in the Enrolled A/es of the Returns of Exch. (partial returns in the Book of Aids); thus ${ }^{4 \text { Hen. } I V \text {. }}$ for W. R. Yorks (some I 50 fees in 20 Ed. III.) the collectors render account of $£_{1}{ }_{2} 6 \mathrm{~s}$. I I $\frac{3}{4} \mathrm{~d}$. for I $\frac{3}{4}$ fees, and the third part of a $\frac{1}{3}$ part of a fee, and 4 car. 7 bov. of land whence 10 etc., and whence 8 bov. make I car. held immediately of the King in W. R., of each fee 20s., and of more, more, and of less, less etc.; and of $27 \mathrm{~s}$. $2 \mathrm{~d}$. of $£ 273$ s. 5d. worth of land held of the King in socage (sine medio) at the rate of 20 . for $£_{2} 20$ and for more, etc.: this is an interesting return, as it would appear that the lands held by others* of "les

*Vide the government volume, "Fcudal Aids," in co. Berks, where the returns cite tenor of Statute 25 Ed. III. (20s. per Kuiight's fee held immediately of the Crown, for more, ctc., and 20s. for each 20 li. la. held of the King sine medio, for more, etc.), but the editor in his introduction (p. xxvi) renders this 20s. per Knight's fec, and the like for 20 li. la. held in socage. The form in the record is of course correct, and as is not unfrequently the case with 
70 Domesday and Feudal Statistics

grauntz" escaped taxation as knights' fees. Conıparison should be made with similar aids of I4 Hen. II., 29 Hen. III. and 38 Hen. III. where

Change of method observed in these returns (1403).

volumes published at the common charge, discovers their editor's failure to understand his subject; thus, in the co. of Cornwall is but $\frac{1}{2}$ fee immediately held, and no capital socage tenant of the Crown [whereas in 1346 (see p. 50) were some $165 \frac{3}{4}$ Knights' fees and of course numerous socagers holding of lords of same]; had the levy in 4 Hen. IV. been per Knight's fee, the above would have owed to respond, as they did in $3 \mathrm{I} \mathrm{Ed}$. I. and $20 \mathrm{Ed}$. III. on like occasions, being then required to be answered de quolibet feodo militari (Rot. Parl., i. 25), and de singulis feodis militum ("Feudal Aids," A.D. I 346). No reader of course should be content to take his views at second hand, when the originals can be consulted, but regarding the vast accumulations of ancient evidences printed during the roth cent., a certain understanding of mediæval usages might justly be expected from any historical writer allowing himself to expound them. It is quite clear that in the 12 th and earlier part of the $13^{\text {th }}$ cent. a capital tenant was answerable as well for his fees held in demesne, as for those held of him by others : it is equally certain that in the 15 th cent. the fees held by others of a tenant in cap. were not esteemed to be by him held in chief -the returns of this aid ( $4 \mathrm{Hen}$. IV.) for 30 counties are extant amongst the Exch. enrolments (the Book of Aids is very incomplete as to same), and including socage total under

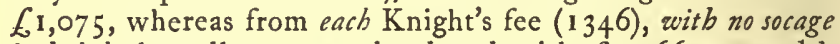
included, the collectors are burdened with $£_{\mathrm{I}} \mathrm{I}, 663$ I 7 s. $7 \frac{1}{2} \mathrm{~d}$. from 36 cos. (the rate $£ 2$ per fee), which would appear to demonstrate that $\frac{1}{6}$ th of the total Knts' fees were then in demesne. A tax of 20 s. on every 20 li. la. held in socage indiscriminately would of course have produced a very considerable sum, but it betrays a singular confusion of ideas to consider the immediate socagers of the Crown as answering to above : some or all capital tenants by serjeanty responded to the $4 \mathrm{Hen}$. IV., but (I think) not so from Wards, Escheats, or Honors, nor from Baronies (to the collectors at any rate). At this date the Bp. of Ely held by the latter tenure for 
the barons answered the tax (in the two latter cases on the scutage assessment, i.e., the I4 Hen. II. render); and with those of i9 Hen. IIl., 3 I Ed. I. and 20 Ed. III., where usually the King's collectors gathered the aid from all the fees they could find : the $6 \mathrm{Hen}$. VI. Inquest cited above, applies but to Returns ${ }^{-1}$ those who had more than $\frac{1}{4}$ fee, and the returns are extremely slender for W. R. Yorks (see Book of Knights' Fees, and the Yorkshire Lay Subsidy of that date), so that the land was presumably held for the more part by tenants under the limit; regarding the later aids of Hen. VII. and Jac. I. I have not found that any estimate by fees was attempted.

In the Inquisitions of $12-13$ John (as abstracted $6 \mathrm{Hen}$. VI. in the Red Book) I find but one note of new feoffment in the case of Gilbert Peche, whose fee might then be in the hands of the Crown; his father's certificate (I I66) is practically repeated, the new being $\frac{1}{2}+\frac{1}{3}+\frac{1}{8}$ in both cases, but occasional references to new fees occur in the records $t$. John in the $T$. de N., presumably of those which had Further been enfeoffed in that reign. In I9 Hen. III. the from the aid to marry was paid to collectors, to the Sheriff, $\begin{aligned} & \text { Testa de } \\ & \text { Nevill. }\end{aligned}$ and also directly into the wardrobe, or Exchequer (see T. de N.) ; to all or many of the magnates the King had written, instructing them to return to the Exchequer a list of their fees as well old as

6 fees, and the Abb. of Glastonbury for 3 (fees), which is the precise no. of Knts. for which they answered in the Marshals' Rolls of 29 Hen. III., 5 and ro Ed. I., and 4 Ed. II., though their service (including fees held by others) in 1166 was to fees each.

No returns of Knights" Fees, $t$. Hen. VII., and $\mathcal{F a c} . \%$. 


\section{Domesday and Feudal Statistics}

new : eight of these charters may be found on pp. 44, 4I5, and $4 \mathrm{I} 6$ of the $\mathrm{T}$. de N., and another (that of Ro. Beauchamp of Hache) is to be seen along with the King's writ in Madox's Form. Ang. I give an extract from the return of the Abbot of St. Edmund's to the Exchequer, who commences by naming the precept of the King, as to certifying how much of the aid for the marriage of his sister had been paid to the Exch. and how much to be paid, how many fees, in what counties and vills, and what of old and of new, and follows "Nos concessisse domino Regi sexies viginti marcas. Ex quibus jam solvimus ad scaccarium medietatem scilicet sexaginta marcas alia vero medietas adhuc restat solvenda. Feoda vero militum de veteri feoffamento habemus quadraginta que tenemus in capite de domino Rege etsi respondemus pro illis pro temporis necessitate. Alia vero xij feoda habemus de novo feoffamento que capta sunt et feoffata de nostris propriis dominicis. Et pertinent ad nostram. Que nulli respondent nec unquam responderent nec respondere debent nisi soli abbati Sancti Eadmundi. Et ipse abbas nemini respondet de illis predicta vero feoda partim sunt in Norff' et Suff' partim in Essex'. In quibus vero villis sint constituta vel quid et quantum in quo loco Deus novit." Now be it observed that the Edmondsbury service was 40 , and that in I 68 there were some $52 \frac{1}{2}$ old and $\frac{1}{4}$ new fees; hence it appears the Abbot in 1235 understood by new feoffment any surplus fees beyond what he was wont to answer for to a scutage, and also he seems to have compounded at a rate equal to 60 fees; likewise the Abbot of 
Ramsey who pays 60 and 100 marcs respectively in 1235 and 1242 * equal to 30 and $33 \frac{1}{3}$ fees. The King's mandate to the Sheriff of Norfolk and Suffolk (p. 282 T. de N.) dated 6 May 20 Hen. III. mentions the charters of the magnates, and that the Sheriff shall certify of those holding I fee and less; and presumably a like method might be used in other counties.

The Gascony Scutage has been dealt with in the Preface to Vol. II. (L. R. Rolls Series), notwithstanding the editor's failure to recognise the Yorkshire returns in the Testa de Nevill; (see his note p. 733, Vol. II., ibid., citing T. de N., pp. 625 and 638 ), and it may suffice to add that inquisitions of this date (circa I 242) occur in almost every county named in the T. de N., and to point out that the monastic houses had not commuted their service in the same way as the bishops. Northumberland is well given in the T. de N., as there are inquisitions circa I 2 IO-12 (I 2-I 3 John) on pp. 392-3, collections for the aid to marry (pp. 394-5), and the later Gascony inquests commencing on p. $38 \mathrm{I}$; the following fines from Dugdale's Baronage (citing Pipe and Fine Rolls), may be noticed in this connection; calling to mind that those who "had their service" abroad had scutage (for themselves) of their men, and that said escuage was 3 marcs per fee, but that most of those who fined conceded their scutage also.

* 1235 and 1242 are dates used with latitude for the aid to marry and the Gascony scutage; in neither case were the debts all paid in those years. 


\section{Domesday and Feudal Statistics}

Fines ne trans fretant.

Supposed p. clxi. "the ancient system of assessment for imperial taxadevelopment of the Fee from the Hide.

\begin{tabular}{|c|c|c|c|}
\hline & $\begin{array}{l}26 \text { Hen. III. } \\
\text { Fines } \\
\text { ne trans. }\end{array}$ & $\begin{array}{c}\mathrm{I}_{4} \\
\text { Hen. II. } \\
\text { Render. }\end{array}$ & Notes. \\
\hline Warwick Thos. Earl & $\left\{\begin{array}{l}120 \mathrm{li} . \\
\text { 120 li. }\end{array}\right.$ & $\begin{array}{l}\text { I02 } 3 \text { fees } \\
\text { (32 more } \\
38 \text { Hen. } \\
\text { III.) }\end{array}$ & $\left\{\begin{array}{l}\text { Ist fine lest he trans- } \\
\text { fret } \\
\text { 2nd fine to have his } \\
\text { scutage }\end{array}\right.$ \\
\hline Albini Wm. . & 20 marcs & $33 \quad "$ & 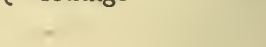 \\
\hline $\begin{array}{l}\text { Beauchamp Ro } \\
\text { Perci WVm }\end{array}$ & $\begin{array}{l}80 \mathrm{~m} \text {. } \\
100 \mathrm{~m} \text {. }\end{array}$ & $17 "$ & \\
\hline Nevill Ro. ... & Io $\mathrm{li}$. & $3 \frac{1}{14}$ & $\begin{array}{l}\text { Heir to the Yorks } \\
\text { fee of Bulmer }\end{array}$ \\
\hline $\begin{array}{ll}\text { Gaunt Gilib.... } \\
\text { Stuttevill Wm. } \\
\text { Umfravill Gilbt. } \\
\text { Baiocis Io. .. }\end{array}$ & $\begin{array}{l}200 \mathrm{~m} . \\
15 \mathrm{~m} . \\
100 \mathrm{~m} . \\
100 \mathrm{~m} \text {. }\end{array}$ & $68 \frac{1}{3} \frac{7}{2},$. & $\begin{array}{l}\text { By Simon, Earl } \\
\text { Hunts, in I } 166\end{array}$ \\
\hline
\end{tabular}

Instances of the so-called "enfeoffment" prior to the Conquest have been already cited from the H. R., and I suppose few will deny that the Hide was a Saxon, and the Fee a Norman institution; but the theory that the figures of I $66-8$ (say total renders) represent the number of Knights due in exercitu $t$. Wm. I., seems fully as improbable as the unwarranted emergence of the Fee from the Hide. The editor of the Red Book (Rolls Series) appears to think otherwise, as the following citations from his preface to Vol. II. indicate:

(I) continued to be apportioned according to the old tion, which in the shape of a common assize plan of hidation-for scutage and aid ...down to a far later period."

p. clxi. "the normal Knight's fee contained 4 hides - a scale which seems to have been recognised as

(2) late as the I 6 th century," with note, citing H. R., II. 830 .

p. clxii. "unless the actual extent of the holding should prove (upon inquisition taken) to contain an 
equivalent for hidation. So when an inquisition was taken throughout the Kingdom, for the

(3) assessment of a Scutage, the Sheriffs were required to return the number of fees in each hundred, estimating their extent by the actual number of hides or proportions of a hide," citing the T. de N. and the Abbot of Ramsey's case.

p. clxiv. "and moreover the extent of the hide or carucate is often stated in denominations of an acre both (4) of arable and pasture land," citing Kirkby's Quest, fo. 228.

It has already been allowed that sub-infeuda- Remarks tions were (or are returned) by Hides and Carucates, whence so many make a fee; the establishment of the feudal system did not of course extinguish hides (as units for rates and taxes) or acres as areal measures, but as less than. 3 or more than 150 carucates might make a fee, and in a feudal tax contribute not by the rate of carucates but at that of fees, it is difficult to discern how this can be termed a tax on the land unit. For instance taking examples from the The theory $\mathrm{T}$. de $\mathrm{N}$. which seems to be indicated in the $\mathrm{refuted}_{\text {numerous }}$ 3rd of the above extracts, on p. 337 the Earl of Records. Chester holds in Horsinton 2 carucates of which Walt. de Bolesby holds I, whence II bovates (i.e., $1 \frac{3}{8}$ car.) make a fee, and lord Simon de Kyme holds the other whence 20 bovates ( $2 \frac{1}{2}$ car.) make etc., and on p. 249 in the Gascony inquisitions in co. Beds., Peter de Lekeburn holds 8 virgates ( 2 Hides) for $\frac{1}{6}$ of a fee ; Walt. $f$. Alex. holds I virgate for $\frac{1}{15}$ of a fee (here $3 \frac{3}{4}$ Hides make I fee), the Prior of Neuham 2 Hides for $\frac{1}{16}$ of a fee ( 32 Hides per fee), and further divers tenants 


\section{Domesday and Feudal Statistics}

hold Hides and Virgates, with the rate of the tenure omitted. The return that the jurors are ignorant of the service is by no means a novelty to those acquainted with records of the kind, and should these unknown fees be made to contribute to a feudal aid, their Hides, Virgates, etc., will necessarily be brought into some proportion. Examples have already been given [20 Ed. III. and 4 Hen. IV. (see pp. 45, 69) aid to Knight and marry, Knaresbro', and W. R. Yorks] of odd carucates and bovates; in the latter, the number of carucates per fee is stated, but in the former not, nevertheless as (see p. 45, Knaresbro') $3 \frac{1}{8}$ fees +2 bovates are given against $£^{6} 5$ s. Iod. in a 4 os. aid, it must be plain that the couple of bovates equal $\frac{1}{48}$ th of a fee, equal to whence 12 etc., just as in the latter record where there are 4 car. 7 bov. over, whence Io etc., they are $\frac{39}{80}$ of a fee, as is proved by the amount received. And further anyone inspecting the inquests of knights' fees (apart from those of serjeanty and socage) in the T. de N. will find it quite exceptional for Hides or Carucates to be named alone; i.e., without giving their varying value as fractions of fees; and naturally if the jurors did not know the amount of tenure they would limit their statement to the convenient hides etc. ; for under the same tenant in capite (see I. P. M. Rog. de Moubray 29 Ed. I., I 300) there might be extremely various scales of subinfeudation, just as in the same Manor the Hide might (even at the same time) contain a different number of acres. 


\section{Feudal Statistics}

The following records from Hen. I. to Hen. VI. will bear out the above;

\begin{tabular}{|c|c|c|c|c|}
\hline & \multirow{2}{*}{$\begin{array}{l}\text { Reign. } \\
\text { Hen. I. } \\
\text { Hen. II. }\end{array}$} \\
\hline $\begin{array}{l}\text { List of Peterboro' Knights (Camden Soc., 1849) } \\
\text { Barons' Certificates (Red Book Exch.) ... } \\
\text { Testa de Nevill }\end{array}$ & \multicolumn{3}{|c|}{ List of Peterboro' Knights (Camden Soc., 1849) } & \\
\hline \multicolumn{5}{|c|}{ dred Rolls $\quad \ldots \quad$... $\quad \ldots$} \\
\hline \multicolumn{5}{|l|}{$\left.\begin{array}{l}\text { Kirkby's Quest } \\
\text { Hundred Rolls } \\
\text { Knights' Fees, 31 Ed. I. }\end{array}\right\}$} \\
\hline$\quad \ldots$ & & & & \\
\hline ook of Knights' Fecs & $\ldots$ & & & Hen \\
\hline
\end{tabular}

The description of the Peterboro' Knights t. Hen. I. will be found on p. I 68 in the Chronicle, and there is no stable relation between the Hide and Fee ; illustrations have already been given or reference made to the Barons' Cartc. ; * H. R. Hen. III., Testa de Nevill, Book of Aids, and the aid to marry Hen. IV.'s daughter (Enrolled a/cs. Exch.), and the following will serve to show the rest are of like nature :

Liber Ruleus. Fee of Nigel de Moubrai (15-25 Hen. III.)

In Haytone ... 15 bovates whence 12 car. make I fce

In Swinton, etc. 3 car.

Kirkby's Quest. Honor of Richmond, Halikeld, I 284.

Eskelby and Lecming $\quad \ldots \quad \ldots \quad 18$ car. makc I fee Uppeslunde
Knights' Fees, $3^{I}$ Ed. $I$. Staincliffe Wap., Yorks.

Neuton and Elslack 6 car. whence 28 make I fec

Cracoe, ctc I 2 , 12 " 1 ,

* See Round's "Feudal England" (p. 294) for 2-10 Hides, per fee in 1166 , and for like evidence in Chartularies (p. 295). 
Book of Knights' Fees, 6 Hen. VI. Staincliffe Wap., Yorks. Lord de Roos holds in

Thornton Joan, Countess of Westmorland holds in Kettlewell
$10 \frac{1}{2}$ car. by service of $\frac{3}{4}$ fee

In the 2nd extract from the Preface to the Red Book, the editor cites H. R., II., 830, where Hugh de Musgrave holds I Hide as $\frac{1}{4}$ fee, which is duly found as stated but it would be singular if so vast a bulk as the Hundred Rolls could not furnish such an instance; here are a few more to be found in same Vol. II. : p. 575,2 fees equal to $6 \frac{1}{2}$ Hides; p. 578 , I fee to 2 Hides; p. $580, \frac{1}{2}$ fee to $3 \frac{1}{2}$ Hides, also $\frac{1}{2}$ fee to 3 Hides, p. $584, \frac{1}{6}$ fee to $\frac{9}{8}$ Hides ; p. $585, \frac{1}{6}$ fee to $1 \frac{1}{4}$ Hides, also $\frac{1}{8}$ fee to 2 Hides; p. 336, I fee "to ro Hides (see "Feudal Aids" where Doddington is given as I fee in 1284, I 302, and I346), also Mursele, Ro. $f$. Nigel, $\frac{1}{8}$ fee to 2 Hides and more, and p. 334 , I fee to $5 \frac{3}{4}$ Hides, which are given to show that the Hide was here a varying portion of the Fee, not touching on the point that in the H. R. it is often an areal measure or approximately so. This same extract notes a scale (where 4 Hides $=\mathrm{I}$ fee) recognised as late as the 16 th century, which possibly refers to pp. $442-7$ of No. 49 Surtees Soc., where is a computation as above, with an editorial note that same seems to have been compiled about the latter part of the 16 th cent.; this scale also gives tables for $6,7,8,9$, IO, I I, I 2, I 3,14, I 5 , I6, I 8, 23, 24, and 28 carucates per fee, not stating which of the latter is " normal." Supposing 
for a moment this " normal" fee really ever did contain 4 Hides (and whether of 120 acres each as in the Preface to the Red Book or 160 each as in the L. R. itself does not much matter), as there were 6,000-7,000 fees (Hen. II. to Ed. III.), and some 67,000 Hides in say 35 counties in England in Domesday; it is evident that the Barons and Church would hardly have possessed 28,000 of them (probably less); whereas few historians should think of rating them at less than $\frac{3}{4}$ of England, say 50,000 Hides.

With regard to the 3 rd extract, which names the Sheriffs estimating Knight's fee by the hides they contained, the reference is seemingly to the Testa de Nevill, the returns from which have already been exemplified; but these remarkable instructions to the sheriffs are not found therein, nor in the "Forma Inquisitionum de Scutagiis," nor in the writ to the Sheriff of Hereford (both these latter on Mich. Com. 27 Hen. III. as cited on pp. 472-3 of Madox's Exch., ed. I 7 I I) nor I should imagine anywhere else than on p. clxii of aforesaid Preface; and as to the extent of the hide or carucate being "given in denominations of an acre both of arable and pasture land," anyone finding same on fo. 228 of Kirkby's Quest will have better luck than I had.

The case of Ramsey Abbey is certainly exceptional; but by Domesday Book that house had well over 300 Hides and Carucates, which in the language of the Exchequer (4 Hides= I Knight's Fee) would be the equivalent of over 70 Knights; as a matter of fact the Abbot 


\section{0 - Domesday and Feudal Statistics}

equipped as a rule 4 (see his Court Rolls for 1258 and I294, in Selden Soc., Vol. II.), notwithstanding aforesaid inquisitions of 1242 estimating Knights' fees by hides (where he contributes as if he had $33 \frac{1}{3}$ fees). The uniform manufacture of Hides into fees at a rate of the "normal four" would be apt to break down in practice; suppose a Baron had a grant of 400 Hides for a service of 100 fees; he might enfeoff roo knights* on 350 Hides at I fee each (as presumably he would have some residence, and tenants in socage and villeinage), and hence (on the 4 Hide plan) the Sheriff would find not unless $87 \frac{1}{2}$ fees instead of 100 ; the above by way of illustration, as $\frac{7}{8}$ of the land of a fief would (I think) be more than was usually sub-infeuded.

Scutagium The subject of escuage is I venture to think and Auxilium. but partially understood, nor can the writer pretend to set it forth in a clear light: the author of "Feudal England" has shown how the Church was set to military service $t$. Wm. I. $†$ (see also Archaologia I 863 and Steven's Royal Treasury, ed. I725), and it is here assumed that the more important lay tenants in that reign also held by the divers duties pertaining to same. As may be seen from table (p. 55), there must have been (on the whole) a considerable balance on the dominicum $t$. Hen. I., and the following extracts from the remaining Pipe Roll of that reign seem to apply to commutations of military service, none

* Ioo Knts., i.e., a "service" of same, indefinite as to nos. and rank.

† Bigelow's Plac. Ang. X Corm., ed. 1879, an American work had long before borne witness on this head.! 
of which (if I have observed rightly) have been thought worthy of mention in the Government index of said vol. Some entries (p. 89) re the old aid of the Knights, two of them dating to the time of debtors' fathers; (p. 132) the gift of the Knights of Durham Bishoprick; (p. I 53) the old aid of the Knights, of Baldwin de Redvers; (p. I 54) the like of the Bp. of Exeter ; (p. I 59) the old aid of the Knights; (p. 49) the like; and (p. 84) the old aid of the Knights of Croyland Abbey (see also Scutage Rolls, Bdle. I I, No. 9, where in $48 \mathrm{Hen}$. III. the Abbot fines in 50 marcs). Again Knight service $t$. Hen. I. is seen in the Peterbro' Chronicle (Camd. Soc. 1849); a systematic commutation of lay service at so much per fee prior to Hen. II. seems highly probable rather than fully* established; the author of "Feudal England" (pp. 268-9) has given 2 references under the name of Escuage, the first* of which is reviewed in Vol. II. Red Book Exch. (Pref. Rolls Ser.) ; Madox has given another in his most excellent History of the Exchequert (p. 435 ed. I 7II I), and yet a further one may be found in Stephen's Charter tc

* The payment of $£ 60$ by the Bp. Norwich ( 40 fees) seems to have no connection with "the Ely contribution" (Feudal England, p. 270), and the reference is quite indefinite: but I consider (as a matter of opinunn), that the entry in Pipe Roll 31 Hen. I., refers to a reduction of the Ely "service," memory of which is preserved in the copy of the Charter, as cited, p. 268, Feudal England.

$\dagger$ Westminster MSS.: Mandate of $\mathrm{H}$. the King to Wm. Const. of Chester that the Monks of Westminster should hold Peritona (D. B. $247 \mathrm{~b}$, under that Abbey), as free from escuage, etc., as the father of said $\mathrm{Wm}$. first conceded same to them. 


\section{Domesday and Feudal Statistics}

Fountains (I 35 ), as to the authenticity of whick. no comment is here made. I would here remark that altho' auxilium and scutagium present different ideas to the modern historical critic, they can sometimes be shown to be terms synonymous; and as unfortunately the scribes of elder times were debarred from having any conception of the precise meaning of technical terms in the 2oth century, latter day students might with becoming humility endeavour to attain the exact usage of words when they were written. Thus the aid to ransom Ric. I. is a Scutage in the Pipe Rolls, and quite properly so called by Alex. de Swereford : likewise the aid to marry (of 19 Hen. III.) is called both auxilium and scutagium: the writ is printed in Brady and Select Charters (p. 364) and reference to the Testa de Nevill will (I think) plainly demonstrate the object of the collection, and the use of either term -indeed the writ itself mentions the aid, subsequently calling same the aforesaid escuage; and further the Scutage of Gascony is distinctly called an aid on p. 412 of the Testa de N.; reference to the same vol. (pp. I66, 169, 257-8, 263-6, 277, 349 , and 416 with 357 for W. Patric's Charter), and collation with the writ, noting the dates and tax per fee, should put the matter beyond question.

Early I do not think, there is in the Pipe Rolls exist-

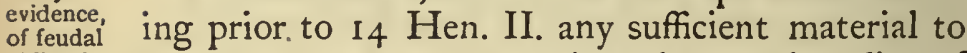
obligations, construct even an approximately complete list of
defective. the services due by the lay tenants of the Crown ; nor can I find the Exchequer had any ample guide towards assessing the aid of I I68. Now altho' the daughter of Hen. II. was not married till 
I 168 , and the certificates are of I 166 , there can be no particular improbability in supposing that the marriage of the Princess Matilda might be in contemplation prior to the former date, and also that the Crown might think it prudent to have some definite information from their lay tenants, which views are by some considered as antiquated. In I Io9 Hen. I. took (Hen. de Huntingdon) 3s. per Hide to marry his daughter : if this is an exact statement, a larger sum (presuming the demesne Hides taxed), would be raised than from the tax on the fee in I168; and strengthens the belief that the lay aids of Hen. I. differed considerably from the escuages Hen. II. to Hen. III. After I I66, Military and during the reign of Hen. II. it would appear Service. that usually the tenant in chief either went on the expedition, compounded by substitutes or money to furnish them, or paid escuage : it is difficult to see how the heading (Pipe Roll I 8 Hen. II.) De Scutagiis ssilitum qui nec abierunt in Hyberniam, nec milites, nec denarios illuc miserunt* followed by lists of capital tenants either owing or liberating into the Treasury could refer to anything else than scutage quitted at a fixed rate per fee. The editor of the Red Book (Rolls Ser.) seems to think otherwise and that the assessment (Vol. II.,

* Perhaps the best cvidence of early fines might be suggested from this heading, unless the "auxilium militum" of 31 Hen. I., or the promise of servientes (Pipe R. I I Hen. II.), or the dona t. Hen. II. are regarded in that light: an instance of escuage being paid into the wardrobe at Worcester (one of the places to which the "army of Wales" was summoned) occurs on $\mathrm{Cl}$. i. $572,7 \mathrm{Hen}$. III. 


\section{Domesday and Feudal Statistics}

p. clviii) of escuage might be to enable the lord to justice his men, which appears scarcely applicable above, nor has he cited any fines "lest they transit " in this reign. Information is needed as to the difference in obligation of church and lay barons, also to what countries the capital tenants owed to go, in what cases there was option of escuage; the obligations of the mesne tenants to their lords, as regards scutage and service, and in what fees the latter were bound to act at their own charges. The author of "Feudal England" has cited the case of the Edmondsbury tenants $t$. Ric. I., and the course taken by the Abbot thereanent; the following illustrate the feudal service of the House at Peterboro', who ought as by 60 fees:

How performed by Peterbro' Abbey.

3 John. The Abbot pays 120 marcs, and owes a palfrey, for army of Normandy of $A \underline{Q}$ 2. (Rot. Canc.)

2 Hen. III. May come with 30 Knts., (Stamford), Newark (Scut. Rolls $\frac{11}{2}$ ).

5 Hen. III. Has escuage of fees held of him-Biham (Cl. i. 475a).

7 Hen. III. Had 6 Knights by precept and to bave $\frac{1}{2}$ his scutage-Montgomery [1 ${ }_{3}^{2}$ Esc. Rolls].

1229. Seems to have paid esc. - Kery : C. Pet.

$1230,14 \mathrm{Hen}$. 1II. The Abbot fines in 100 marcs and pays $180 \mathrm{~m}$. of scutage, for the Brittany exercitus; scutage $3 \mathrm{~m}$. per fee, to our Ist passage. (Chron. Pet.)

1230, 15 Hen. III. Pays 180 marcs scutage (C. P.) after first passage.

1235,19 Hen. III. The Abbot returns $63 \frac{1}{2}$ fees, pays on 60 , and is debited for $3 \frac{1}{2}$. (Testa de N., p. 38.)

20 Hen. III. r. s. 60 fees performed by I Knt., 8 servientes (Rot. Mar.); quit by writ of 40 fees ( 30 Hen. III., Pipe); pays 60 marcs escuage ( 3 m. per fee, hence on 60 less 40 fees), army and scutage of Gannock (H ist. Pet.).

29 Hen. III. Pajs $60 \mathrm{~m}$. only ( $2 \mathrm{~m}$. per fee), to the aid to marry (Hist.).

1264. The Abbot's Knts., joining the Barons, he pays $300 \mathrm{~m}$. (and $30 \mathrm{~m}$. queen gold), for defect of service, and transgression-after Lewes he has to fine with the Barons (Hist.; vide etiam p. 93 under 49 Hen. III., where the entry above seems to be given in a different way).

1265. After Evesham, the Abbot pays the King $500 \mathrm{~m}$., the Queen $50 \mathrm{~m}$., Prince Edw. 300 m., and also to others (Hist., see also note, p. roo).

1277, $5 \mathrm{Ed}$. I. The Abbot fines in 250 marcs for 5 fees, and $25 \mathrm{~m}$. Queen's gold, for the first Welsh war, his tenants having declined to go except at the Abbot's costs. (Chron. Pet.)

$1279,6 \mathrm{Ed}$. I. The King conceded scutage at 40 . per fee, or the above war, which the Sheriff was to cause the Abbot to bave. (Chron. f'et.) 
12S2, $10 E d$. I. The Abbot fines for the and Welsh war, at the same rate as in 1277 , and has acknowledgement of receipt of fine 10 Jan., II Ed. $I$. (Chron. Pet.)

1235, $13 \mathrm{Ed} .1$. The King in Parliament concedes scutage re above, at 40 . per fee, and the Sheriff has a writ, $7 \mathrm{July}, \mathrm{r}_{3} \mathrm{Ed}$. I. to cause Abbot to have same. (Clron. Pet.)

29 Ed. I. The Abbot fines in $£_{200}$, and $£_{20}$ Queen gold; Scotland (Hist.), for rates per fee, see pp. 94-5.

31 Ed. I. Fines 6100 , and 6 ro Queen gold; Scotland (I/ist.).

34 Ed. I. Fines room., and rom. Queen gold (Hist.)

4 Ed. II. Fines $£_{200}$ for 5 fees, and $\ell_{20}$ Queen gold, and finds $100 m$. of provender (for the army of Scotland), which he has to carry [Sc. Rot. 12 , and $H$ ist.; see also note p. 100 ].

15 Ed. II. Gives $200 \mathrm{~m}$. of subsidy to repress Thos., Earl Lancaster's rebellion (Hist.).

16 Ed. II. Fines in $£_{200}$, and $£_{20}$ Queen gold, Scotland-no general levy of escuage (Sc. Kot. $u$, and $H$ ist.).

$I E d$. III. Fines in Eron, and Ero Queen gold, Scotland (Hist.).

$16 \mathrm{Ed}$. II. The Abbot fines in $\complement_{200}$ for 5 fees (for the Scotch exercitus presumably) - no general levy of escuage. (Sc. Rot. 스.

now it will be observed that the Edwardian fines are not based on the "service," and it may also be noted the fine with escuage was under $5 \mathrm{~m}$. per fee in $1_{4}$ Hen. III., $\mathrm{r}_{2} 30$, whereas it was but about $f_{\mathrm{I}}$ per fee 5 and ro Ed. I. (by theory at least) as some 175 marcs should accrue on either occasion, as his escuage-the money received by the Crown being much the same as in 1230 . The Exch. Common Roll 17 Ed. III. (cited both by Brady and Madox) gives the case of the Prior of Coventry who Prior of t. Ed. I., and t. Ed. II. fined for 2 fees (service Io); Coventry's both these authors observe the Prior's Plea was false, but neither of them record judgment: certain it is many capital tenants fined just in the same way as the Prior, and it is difficult to suppose any systematic deception could have taken place with the evidence then on record in the Pipe Rolls. The charter of the Prior of Coventry to the King (aid to marry I 235) is on P. 94 of the $T$. de $N$, and an inquisition of his fees in Warwick 
and Leicester (p. 97) in 1242 follows; in 1166 he had $7 \frac{5}{6}$ of old and $2 \frac{1}{6}$ fees in demesne: the King's advocates either could not or would not answer the Prior's argument which appears to be entirely misapprehended by both the distinguished authors citing the case-what the Prior pleads is that he and his tenants paid on 10 fees to two aids to marry, and that his certificate of in 66 duly acknowledges $\mathrm{I} \circ \mathrm{fees}$ as by him and his tenants, but that he held by the service of 2 fees only, and challenges any recorded proof to the contrarynone produced. This probably refers to the $2 \frac{1}{6}$ fees in demesne, for which the Prior fined (i.e., 2 as above), or in other words his service was IO, two of which he recognised in exercitu (e.g., a Marshal's Roll showing the Prior had sent io knights would have shown the Crown to be seized of the "service" of Io fees in the Prior's sense, but seemingly was not so found), noting that the defendant used the term "service" with a different meaning than that which is attached to it in modern writings (including this chapter). Now if the lord could compel his men always to do corporal service at their or even his own costs, he would not have paid exemplary fines, and it is certain that nothing Esciage
tenants. with difficulty or not at all) from some of the mesne tenants; but I have not found that it was the more usual practice both to fine and concede scutage to the Crown. From the Church often something more than her service seems to have been expected, but from Hen. II. to I Ed. III. many lay capital tenants appear to have escaped by 
paying or owing escuage. Madox in his chapter on Escuage cites (I think) but 4 cases of actual disseisin; such however was common enough, and no one acquainted with the records of John and Hen. III. will consider amplification needful : it may just be noted that disseisin was not disherison, Disseisin. and often appears to have been a mere formal process of taking possession on account of the unsatisfied claim of the Crown to the tenant's corporal service, or its pecuniary unpaid equivalent; the malevolence of the King being averted, and seisin recovered when the tenant came to terms on the matter. In and prior to Hen. I. forfeiture seems to have been frequent, but the attentive reader of History must have often observed that traitors and rebels by no means necessarily lost their estates (even temporarily), and frequently, having been disinherited, regained them in their own persons (or by their heirs) - nor must it be supposed that disseisin* was the inevitable sequence of failure to attend the royal summons (bearing in mind that records do not show that half the Crown capital tenants had usually a direct summons), e.g., $P$. Writs $30 \mathrm{Ed}$. I. where Jo. $f$. Reginald is directed to proceed against the Scots, having previously per diversas vices neglected to obey such summons, and again I 3 Ed. II. (P.W.) when the King states that "very many of our realm" who should have done service in the army of his fourth year, neither did it, nor fined, which is to be compared with the already cited heading in Pipe I $8 \mathrm{Hen}$. II., and the nec ierant nec miserunt of Walt. Coventry in 1213.

* For an early instance of, see p. 105. 
88 Domesday and Feudal Statistics

Obligations of undertenants.

That the undertenant (John-Ed. II.) was more frequently of pecuniary than personal assistance seems to be supported by evidence as knownProf. Maitland cites the legal view of a Knt. failing to do service t. Hen. I. (Cbron. Abingdon, ii., I 28); the Earl of Chester's Knts. are to be compelled to render him service (presumably partly or wholly of a corporal nature) in Io Jonn (Pat. Rot.); and a tenant's superior lord is to have full seizin if former is unwilling to transit for him in I4 John (Cl. Rot.) ;-nevertheless it is apparent enough that of very many mesne tenants there is no further obligation to their lord than to pay escuage, however they may stand to the Crown in the matter of fealty, as if I have rightly observed, they would be a class liable for summons amongst the iurati ad arma.

In the Scutage Rrills (Chanc. Misc. $\frac{11}{18}$ ) in 10 Ed. III. is a mandate to the Sheriff of Yorks to cease distraint on the Luterell estates, because by the Rolls of the Marshal $t$. Ed. I. it appears that Ro. Luterell, deceased, had his service for 2 fees which he acknowledged, in $5 \mathrm{Ed}$. I. in the Ist Welsh war ; hence it appears that the Scutage due in 1278 was still owing to the Crown in $1316-17$, $^{*}$

Inadequacy of Scutage entries in

* It seems clear that the notes as to tenants in 1278 ( $P$ ipe Roll 7 Ed. I. Ebor.) are indefinite, as some had, and others had not done service in the war of 5 Ed. I., but Ric. de Pipe Rolls, Malebisse who had been summoned to perform military
t. Ed. I. service in person (Muster at Worcester 5 Ed. 1.) does not acknowledge nor fine for same, but is noted in the $7 \mathrm{Ed}$. I. Pipe Roll, as paying 4os. scutage for I fee (which was held of the Hon. of Eye). Again Peter de Mauley did his service, 
and further that when Scutage was assized, it might be collected either for the tenant or the King. Turning to the Pipe Roll 7 Ed. I. Yorks, the Scutage of Wales was assized at 4 OS. ( $£ 20$ seems to have been actually paid then) whereof Ro. Luterell is Double noted with $f_{2} 25$ for $12 \frac{1}{2}$ fees, with a reference to "Service," the last Welsh Scutage, i.e., 42 Hen. III. at a illustrated similar rate: the names seem to have been copied Lyterell from a former roll or rolls with alterations of ${ }^{\text {case. }}$ Christian names (thus Ro. Luterell succeeded in 5 Ed. I., his grandfather Andrew being tenant in 42 Hen. III.), and hence in ro Ed. III. it might well appear that the executors of the said Ro. stood charged with the Escuage of 1278 . Now it may be remarked that the Luterell property ought the

acknowledging 2 fees, (appearing in person with another Knight at the Muster at Rhuddlan $10 \mathrm{Ed}$. I.) : nevertheless both in the Pipe Rolls of 10 and I 4 Ed. II. he is debited with $\mathrm{E}_{3} 3$ scutage for that particular campaign : his service being $3 \mathrm{I} \frac{1}{2}$ fees, as he inherited the estates of Wm. Forsard who rendered that number (Pipe Roll 14 Hen. II., Ebor.). Most of those capital tenants specially summoned for the $5 \mathrm{Ed}$. I. Welsh war, from Yorkshire [unlike the total for England, where about half of all specially warned neither come, send, nor fine-Marshal's Roll 1277] fine, or "make," or " have," but there are no writs of quittance noted on the Pipe Rolls of 5, 6, or 7 Ed. I. re this army; that King however seems not to have effectively pressed the collection of escuage (see Parl. Writs t. Ed. II.), and as shown in the Luterell case, such was being collected in Io Ed. III. Edward II. collected or attempted to collect the escuages of Ed. I.-most of the Yorkshire entries (Pipe Rolls 7 and 13 Ed. I.) give no further information than the number of fees each tenant had (the Welsh war of $10 \mathrm{Ed}$. I. is the last of which any regular entry of escuage is made for this county), and could be but of slight use as a guide to what was due to the Crown. 


\section{0 \\ Domesday and Feudal Statistics}

service of $12 \frac{1}{2}$ fees and recognised such by 2 knights in the King's army, and that said fees were those for which Ro. de Gant sent in a Charter in I I 66 ; in I I 68 (being one of the eleven exceptions) he rendered $\mathrm{I} 7$, but paid then on $12 \frac{\mathrm{I}}{2}$ only, and is not on the rolls till 2 Ric. I. when the fee is given as

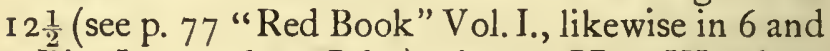
8 Ric. I., I and I 3 John), also 38 Hen. III. where account is rendered by the Sheriff of $\AA^{2} 5$ of I $2 \frac{1}{2}$ fees of Andrew Luterel, of Maurice de Gaunt, in the aid to Knight Prince Edward.

The following illustrations save where otherwise stated are from Madox's "Hist. of the Exchequer" :

Examples I8'Hen. II. Glastonbury Abbey in the hands of the King :

from Madox, etc. therefore unrecognised fees paid.

7 Ric. I. Ro. de. St. John r.c. 15 marcs, lest he transit, and to have escuage of I fee.

7 Ric. I. Matilda Countess of Warwick r.c. $40 \mathrm{~m}$., lest she send Knights o'er sea, and to have escuage of 15 fees. [Scutage $f_{1}$ i per fee.]

8 Ric. I. Bp. Coventry r.c. $\ell_{2} 5$ lest etc., and to have escuage of 15 fees of the Bprick and 10 of the Priory [seems an even fine].

$I$ Fohn. Ro. de Turevil r.c. $5 \mathrm{~m}$. for $\frac{1}{2}$ fee which he holds in demesne, lest he transfret with horses and arms.

$I$ Fobn. Hen. de Witefeld owes $4 \mathrm{~m}$. lest etc., who holds $\frac{1}{4}$ fee in demesne.

$I$ Fohn. Geoff. de Mandeville who holds in demesne I fee r.c. $£ 5$ lest etc., and to have scutage of said demesne.

3 Fohn. Ric. Descrupes owes $£_{5}$ for 3 fees, lest, etc.

I2 John. Earl Clare r.c. $500 \mathrm{~m}$. for his passage, Ireland, (and is quit of escuage, Pipe I $3 \mathrm{John}$ ).

I4 Hen. III. Fines and Scutages ( 3 marcs per fee) for the King's first passage to Brittany :

Abbot Evesham r.c. $£ 20$ for passage, and for scutage of $4 \frac{1}{2}$ fees 
Abbot Pershore r.c. £io for passage, and for scutage of 2 fees.

Abbot Abbotsbury r.c. $\oint_{5}$ for passage, and for scutage of I fee.

Abbot Westminster r.c. 100 marcs of fine for scutage of 15 fees.

Abbot Michelney r.c. $3 \mathrm{~m}$. by the Sheriff for I fee.

Abbot Cerne r.c. 6,5 for passage and scutage of I fee; r.c. $f_{2}$ of scutage of $\mathrm{I}$ fee, for which he did not fine.

Bp. of Bath (20 fees) gave $\oint_{120}$ of aid, partly pardoned.

Prior of Coventry r.c. $35 \mathrm{~m}$. for his passage and to have escuage of his 10 fees.

Ro. de Covo Burgo r.c. $20 \mathrm{~m}$. for his passage, saving to the King, scutage of his 15 fees.

I8 Hen. III. The Bp. London r.c. $60 \mathrm{~m}$. of fine to be quit of sending Knights, and to have his escuage, and should the King pardon scutage to any of the Bp's Knights, same to be allowed for in the fine [ 20 fees]. $20 \mathrm{Hen}$. III. Re exceptional grant by ecclesiastics of an aid of 2 marcs per fee as well those usually answerable to escuage, as others retained to their own use; not to be prejudicial on future occasions; (refers to the aid to marry, and is from record citing it).

27 Hen. III. Receipt of 50 marcs subsidy of the Abbot of Hyde in consideration of which he will respond for escuage of 15 instead of 20 fees.

7 Ed. I. The Bp. Lincoln fines in 680 for 5 fees (service 60) which he recognised for 1 st Welsh war.*

$7 E$ d. I. Order to levy scutage of 4 os. per fee from capital tenants, etc., $r e$ above.

$27 E$ d. I. 2 cases of quittance of escuage of capital tenants for army of 5 Ed. I. who respectively "had," and fined for service: (Lancs. Lay Sub.).

$3 I$ Ed. I. (Brady Vol. I. Hist. p. I 20) Hen. de Perci who was in the Scotch expedition of $3 \mathrm{I} \mathrm{Ed}$. J., to have $£ 2$ per fee scutage.

$3 I E d$. I. (Brady, ibid.) Hen. de Lacy to have $\oint_{2} 2$ from each

* Hist. Exch., p. 460, ed. 1711 ; of. Peterboro' Abbey,

5 Ed. I., already cited, p. 84 . 


\section{2 \\ Domesday and Feudal Statistics}

of his fees, as he was in the King's service negotiating in France, during the exercitus of $31 \mathrm{Ed}$. I.

$34 E d$. I. Similar order to last, re Scotch expedition.

$9 E d$. II. 4 cases of distraint of escuage on mesne tenants for armies of 28,31 , and $34 \mathrm{Ed}$. I. ; mandate that same should cease, unless at aforesaid time the lord of said mesnes was within age, and in the King's hands.

9-I2 Ed. II. Two cases showing that in this reign the tenant of an honour was bound to give scutage, but not to do corporal service.

IO Ed. II. Debts of Scotch expeditions of 28,31 , and 34 Ed. I. to be collected at the rate of $f_{2}$ per fee as scutage, and enquiry as to capital tenants, escheats, honors, perquisites, wards, and vacant ecclesiastical holdings-reference to above in a mandate to the Commissioners.

I5 Ed. II. Summons for an expedition against the Scots, in which ecclesiastics, widows, and other women are to be allowed to fine at 6,40 per fee.

20 Ed. III. (Brady, Vol. I. App. pp. 86-8) Expenses of the army of this year, showing its composition, wages, etc., (a Knight 2s. per day).

Payment of Scrtage.

Now it seems clear that it was easier to pay Escuage than to fine, and certain tenants appear to have escaped by the former plan: why some should stand as quit paying or owing scutage is difficult to discern, further than on such general grounds as expediency, negligence, favoritisn, relative strength of the Crown, abilities of tenants, etc., bearing in mind that wards, escheats, perquisites, honors, and vacant bishopricks explain the matter in many (but certainly not all) cases. The following references are mainly from original matter at the Record Office, dealing with the final period (up to I Ed. III.) beyond which I do not-find any notice of a general levy of scutage in England; as 


\section{Feudal Statistics}

Madox's Hist. Exch. and Parl. Writs (the only works assaying satisfactory illustration), do not bring the History of Escuage quite to a close :

29 Hen. III. Aid granted I 242, $\mathscr{L}_{1}$ per fee, to marry the Examples

King's daughter noted for Yorks in the Pipe Roll, from MSS., on basis of render of 1168 .

38 Hen III. Aid to knight Prince Edward, noted on Pipe mostly unprinted.

Roll, at $\ell_{2}$ per fee, generally on same basis as above though theoretically on "old" and "new" feoffment.

$42 \mathrm{Hen}$. III. Escuage for Welsh war, at 40 s. per fee, noted for Yorks on Pipe Roll, same basis as above, i.e., render of 1168 .

49 Hen. III. Chanc. Misc. Bdle II, No. 9. Fines for services due to the King in his army anno 48 ; totalling $\oint_{1}, 302$ IOs.; (c. 68 entries) thus :

Abbot Glastonbury $\quad \ldots \quad 60$ marcs.

"Abingdon ... ... 60 ,"

" Hyde ... ... 50 ",

"Croyland ... ... 50 ,

Thos. Kyn' $\quad . . \quad \ldots \quad 40$,

Chapter of Lincoln ... 40 "

Bp. Salisbury $\quad \ldots \quad$... 50 "

Bp. Durham _.. … 100 ,

Abb. Peterbro' (as well for service as of his gift) ... 300 ,"

5 Ed. I. (Chanc. Misc. $\frac{11}{1} \frac{1}{8}$ ) Order to Sheriff of Yorks in IO Ed. III., to release distraint on Luterell estates for scutage of 5 Ed. I., as Ro. Luterell decd then had his service for 2 fees.

$7 E d$. I. Scutage of Wales assissed at 40 os. per fee with reference to $42 \mathrm{Hen}$. III.; a list of most of the Yorkshire capital tenants, some of whom fined, had or did service, but nothing to indicate this on the roll, the names being proper to $7 \mathrm{Ed}$. I., and not to $42 \mathrm{Hen}$. III. ; 20 paid; the fees on basis of 1168. ro Ed. I. ( $\left(\frac{11}{9} S\right.$ S. Rot.) Fines for army of Wales; $c .90$ entries. I4 Ed. I. Another list, presumably of the second Welsh war, on same basis as 7 Ed. I. ; both Yorks Pipe Rolls. 


\section{Domesday and Feudal Statistics}

28 Ed. I. ( $\left(\frac{11}{9}\right.$ Sc. Rot. $)$ Fines for army of Scotland, at 40 li. per fee-total $£_{1}, 975$ 6s. 8d. in c. I 5 entries.

$28,3 I, 34$ Ed. I. Lay Subs., $\frac{141}{1}$. Collection of escuage (Middlesex) at the rate of 40s. per fee for the armies summoned for Carlisle (28 Ed. I.), Berwickon-Tweed (3 I Ed. I.) and Carlisle (34 Ed. I.), seemingly paid by undertenants.

28 and 34 Ed. I. King's writ in 4 Ed. III, to the Sheriff of Westmorland that the executors of Marmaduke Twenge deceased (who was with the lord Edward grandfather of the now King in the Scotch expeditions) should have scutage, at 40 . per fee, both for 28 and $34 \mathrm{Ed}$. I.

$3 I E d$. I. ( $\frac{11}{9} S c_{0}$ Rot.) Fines for Berwick army at 20 li. per fee-total $\oint_{1}, 777$ Is. $8 \mathrm{~d}$. in c. 32 entries-thus Archbp. of York (service 20), $\oint_{1} 100$ for 5 fees.

34 Ed. I. ( $\left(\frac{11}{9} S\right.$ S. Rot. $)$ Fines for Carlisle army at 20 marcs per fee-total $£_{1}, 881$ os, $\circ \frac{1}{2}$ d. or more, in c. 69 entries.

34 Ed. I. (Chanc. Misc. $\left.\frac{11}{1} \frac{1}{8}\right)$ Writ in 5 Ed. III., that whereas Wm. la Zouche fined for his service in Scotland $34 \mathrm{Ed}$. I., said Wm. to have scutage at the rate of 4 os. per fee.

34 Ed. I. (Yorks Pipe Roll) The Archbp. York fines in 100 marcs for 5 fees which he recognises: notes of presumed debts of Welsh scutage.

$35 E d . I ., I E d$. II. Like entries as to Welsh scutage on Yorks Pipe Roll.

4 Ed. II. (Chanc. Misc. $\frac{11}{1} \frac{1}{8}$ ) Writ of 2 Ed. III. to the Sheriff of Surrey and Sussex to the effect that, whereas our father (Ed. II.) by divers writs, commanded that our beloved Abbot of Hyde, who had his service in Scotland (4 Ed. II.), etc., should have escuage at the rate of 2 marcs per fee, and that as said Abbot has informed us that same has not been levied, etc. - to cause said Abbot to have, etc.

4 Ed. II. (ibid.) Writ in 4 Ed. III. to the Sheriff of Lancs that executors of Marm. de Twenge deceased, should have escuage.

$4 E d$. II. (ibid.) Writ in 5 Ed. III. to Sheriff of Somerset to cause Wm. la Zouche to have escuage re 4 Ed. II. 


\section{Feudal Statistics}

4 Ed. II (Subs. $\frac{91}{5}$ ) Derby ; collectors' accounts of escuagc, presumably from undertenants, at the rate of 2 marcs per fee.

4 Ed. II. (Sc. Rot. $\frac{11}{9}$ ) 9 entries of fines at $£ 40$ per fee for army of Scotland.

6 Ed. I1. (ibid.) Fines for respite from service; c. 52 entries. 6-7 Ed. II. (Cbanc. Misc. Bdle. 11, No. 9) Fines thus: Jollan de Nevill 40s. for respite of service due from I fee till the Nativity of St. John the Baptist : Aucher $f$. Hen. recognises the service of $\frac{1}{2}$ fee, and makes fine (see $\mathcal{P}$. $W$.).

7 Ed. II. ( $\frac{11}{9}$ So. Rot.). Fines for army of Berwick, at 20 marcs per fee ; $c .40$ entrics.

8-II Ed. II. (Chanc. Misc. Bdle 11, No. 15) Roger de Mortimer, who was with the King, etc., to have his scutage.

IO Ed. I1. (Yorks Pipe Roll) Notes of presumed debts of 2 Welsh scutages of Ed. I. ; Geoff. Luterell pays f25 for $12 \frac{1}{2}$ fees, for the 2 nd scutage, for his father deceased ; it is interesting to note that Ro. Luterel acknowledged 2 fees in $5 \mathrm{Ed}$. I., and did his service; in $10 \mathrm{Ed}$. I. he was summoned, and clearly seems not to have appeared nor fined (there are many writs $t$. Ed. II. stating that as tenant had fined he is not to be distrained for scutage, or to have his escuage), his son paying the scutage on $12 \frac{1}{2}$ (not 2) fees, 35 years later.

13 Ed. II. ( (11 Sc. Rot.) 5 fines for army of York at $\$ 20$

I4 Ed. II. (Yorks Pipe Roll) Entries of presumed debts of escuage for the 2 Welsh wars of the last reign, on basis of 1168 .

16 Ed. II. ( $\frac{11}{9}$ Sc Rot.) $£ 580$ fines for army of Newcastle at Eto por fee :

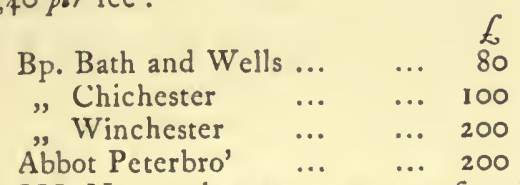

$I, 2,3 E d$. III. No entries as to escuage found on Yorks Pipe Roll. 


\section{Domesday and Feudal Statistics}

$I E d$. III. (Cbanc. Misc. $\frac{11}{1} \frac{1}{8}$ ) Writ of I I Ed. III. to Sheriff of Somerset to cause Abbot of Glastonbury to have his scutage for fine made for service in Scotland I Ed. III.

$I E d$. $I I I$. (Subs. $\frac{202}{38}$ ) Account of collectors of the E.R. Yorks (in or after I 3 Ed. III.) as to escuage of I Ed.III., showing that nothing had been levied, the King having stopped levying till further demand. I Ed. III. ( $\frac{11}{9}$ Sc. Rot.) $\$ 778$ fines for army of Newcastle, at $£ 20$ per fee ; in c. 26 entries.

I2 Ed. III. (Fones' Index, citing Hil. I 2 Ed. III. Mem.) Jo. $f$. Ro. de Ros to be attached for view of account of scutage.

I2 Ed. III. L.T.R. Mem. Commission to collect scutage of I Ed. III.

I2 Ed. 1II. Fadera. To defer collection of above scutage till further orders ( 1338 ).

20 Ed. III. (Chanc. Misc. Bdle I1. No. 19) Fines thus : Ric. de Goldesbrough miles, for 5 marcs for expenses of I hobelar; Humph. de Bassingbourn miles $26 \mathrm{~m}$. for expenses of 2 men at arms and I hobelar -but no note of fees, being assessed on value p. a. of land or rents, commencing at $\ell_{5} 5$ (one archer).

9 Ric. II. Parl. Roll. Petition (granted) that no escuage shall be challengeable on account of the King's $1^{\text {st }}$ expedition to Scotland.

1372. (Fœdera). The Irish Exch. Barons not to exact scutage from persons whose possessions are held by the rebels.

There is no evidence of any general levy of escuage (ut credo), in England, after $t$. Ed. III., its extirc- but there is not infrequent mention of it in the tion in the Rolls of Parliament, and some evidence of its century. existence as a rent charge* - however scutage was not abolished in I64I, when the House of Con-

* Inter alia: Wm. Angevyn held $\frac{1}{2}$ the Manor of Hebden of the Abbot of Fountains by homage, fealty, scutage, and a rent of 8 s. p. a.-I.P.M. I 5 Hen. VII. 
mons were to take it into consideration, possibly in alarm lest it might be utilised to meet the exigencies of their unfortunate monarch, who is reported to have been benefited to the extent of f. 100,000 , or $f_{1} 173,5379$ s. 6 d., by the compositions for Knighthood of the 40 librate holders.*

The popular idea of the servitium debitum is Popular clearly stated by J. A. C. Vincent (Lancs. Lay service in Subs., p. I 16), in his expansion of a writ of exercitu. military summons, to wit, in the proportion of one Knight to each fee, whereas the mandate requires habeant ibi pro se servicium suum nobis debitum;the simplicity of a theory asking credence for the muster of the whole Knight Service of the kingdom to a particular place on a given day one very much admires at. Like views appear to be expressed in Feudal England (pp. 270-r, J. H. Round), and p. 292 where that author labours hard to equate a scutage of 2 marcs per therefee with the service of a Knight for 40 days; in ${ }^{\text {anent. }}$ the excellent work of the Bishop of Oxford (Const. Hist. i. 589); $†$ and also in The Scutage and

* Archæologia, 1863.

$\dagger$ It would of course be impossible for any author to fathom every detail in so vast and laborious a work as that under note; at the same time a levy of one-third of the milites by tenure, would be (I think), as large a proportion as ever recorded; the chronicler himself styles it maximam expeditionem, ita ut duo milites de tota Anglia tertium pararent ad opprimendum Galenses (Chron. Norm. p. 993, Ducbesne), and it must be remembered that King John, when rassing the country to resist invasion, ordered quod novem milites per totam Quotas of Angliam invenient decimum militem, and in 4 northern countics service. a portion of this quota $\left(\frac{1}{10}\right)$ was to be retained to guard their 
Knight Service in England (p. 108, J. F. Baldwin), which is perhaps the best modern work on the feudal system of this country.

Certain it is the Abbots of Evesham, Ramsey, and St. Albans, and the Bishop of Durham did all, and sometimes more (the two latter) than the same service for which they responded to escuagebut what evidence remains (by no means inconsiderable), demonstrates that most of the ecclesiastics and laymen did very much less. At

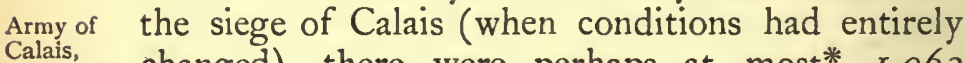
Calais,
A.D. I346. $^{2}$. changed), there were perhaps at most*
1,063 English Earis, Bannerets, and Knights, with some 3,000 esquires (in feudal language c. 2,500 fees), all at wages [vide MS. Harl. 3,968, which is fuller than the Heralds' Coll. copy printed in Creci and Calais]; and a professional writer [the Hon. Gen.

own parts (Pat. Rot. 6 John). The same author (Ro. de Monte, ut sup. Chron. Norm.) gives the interesting reference (vide Duchesne, 995), cited in Feudal England (p. 280) whose author suggests the chronicler is at fault, as the escuage represented but a minority of the fees: the available records do not demonstrate that at this period the Exchequer were seized of any evidences which would enable its Barons to form a competent conception of the number of fees held by the lay Crown tenants; it would seem probable that many records perished $t$. Stephen, as when ancient evidences are called for of a general nature, the Crown instructs its officers to produce Domesday Book, and the Barons' Certificates, so that apparently these were all the records to hand.

* This estimate of course includes all the English men at arms present whether Crown tenants or not: some of them presumably had no landed property whatsoever-cf. chescun Esquier nient possessionez des terres, rent, ne cbateaux, q'est en service ou ad este armez [2 Ric. II.]. 


\section{Feudal Statistics}

Wrottesley], states this to have been the most complete expedition despatched from England till the I 9 th century.

In I 4 Hen. II. and $38 \mathrm{Hen}$. III. are some I I and 9 cases of services of upwards of I00 fees "Suprosed (to escuage), and yet one thinks the authors of "services" the accepted theory of all the feudal milites* Knighis. $^{200}$ doing service together in the same army would be particularly distressed to prove an actual service in the army of 20 fees even in 5 cases, or of 40,50 , or 100 fees in any single case whatsoever: 40 may have been a possible number, as the Earl of Salisbury allows such to be his debt in exercitu in I r66 (fees to scutage $56 \frac{4}{5}$ and $55 \frac{1}{4}$, I 8 Hen. II. and 38 Hen. III.) - but the Baronial Charters themselves often furnish undeniable witness that the services are of divers natures. There is fairly ample evidence as to the armies of John and Popular Hen. III., and no lack of same $t$. Ed. I.-II., and theory of in no case (ut videtur mihi) anything approach- Service im- $_{\text {probable }}$ ing 20 milites by any baron; nor is it likely that per se, and (in the earlier period) all the feudal milites could lacking have been entirely withdrawn from the Castles, support of especially on the Welsh and Scotch borders, thus

Records.

* Milites-a difficult term, Wm. I. to Hen. II., and scarcely quite equivalent to the same t. Hen. III. to Ed. I. ; in $3^{8}$ Hen. III. the Bannerets and Bachelors by tenure might total 1,000 , or possibly 1,$500 ;-t$. Ed. I. there is evidence of a considerable force, including the vadlets, servientes, or esquires, but by far the more part of same ad vadia nostra.

$\dagger$ Earl Richard (89 fees et amplius) led 20 milites and 40 servientes (probably archers on foot for the more part) in the army of Walcs, (Pipe Roll, II Hen. II.). 


\section{00 Domesday and Feudal Statistics}

depriving the land of its natural leaders, and tending to place the much decried (C. Oman, M.A., Art of $W$ ar, and Prize College Essay) abilities of our mediaval capitanei, more nearly on a level with those of their modern critics.

Now true it is that the wages* of a miles for

Expenses of military service.

Bargains wilh hired Knights ; aclual case in 1284 , between tenant and miles.

* The siege of Kenilworth is said to have lasted from June 25 to Dec. I3, 1266 (Const. Hist., ii. 96), and the Abbot of Peterboro' (as other prelates), was summoned for his service (at this period the equivalent of $5 \mathrm{Knts}$ ); the expedition seems to have cost him fir24-5 (Hist. Pet.), but no definite dates occur save 3 weeks after Aug. 24, and 15 days after Nov. I-amongst the items are 17 horses depradati de pretio $£_{4} \circ$, and 10 lorica cum toto apparatu de pretio $£_{15}$. Later at Shrewsbury are entries of the expenses of brother Wm. Paris, cum toto servitio, for 6 weeks, $\oint_{1} 1418 \mathrm{~s}$. od., and in purchase and repairs of arms $f_{6} 14 \mathrm{~s}$. od. ; in $4 E d . I I$. the King wrote to the Abbot (vide Hist.) for his service for Scotland (suppose 5 milites) whereupon he sent him Wm. de la Zouche (miles), with horses and arms, at a cost exceeding 60 marcs, but nibil placuit regi, so the Abbcy fines for 5 fees in $£_{2} 200$, etc. (see p. 85). The cost of a hired Knt. would to some extent be regulated by the fines to the Crown, to knowledge of which the contracting parties could be no strangers - thus in 1284, the Abbot of St. Augustine's (scutage service, 15) arranged with Wm. de Cobeham (miles), to quit them of all military service due to the Crown (sc. I Knt. in exercitu, see Rot. Mar. Io Ed. I., and Chron. $W$. Thorn), for $f_{0} 20$. As the fines for this army (Wales) were $50 \mathrm{~m}$. per fee (queen gold $5 \mathrm{~m}$.), it is evident the Abbey saved $£_{1} 6$ I3s. 4 d. by the above pact, but it should be noted that the liabilities (ransom, loss or injury to horses, etc.) of the service would probably fall on Wm. de Cobeham. The wages of a miles at this period were $2 \mathrm{~s}$. a day, and apparently rather a mere average equivalent for housing, and provender, in time of war for himself, his vadlets, and horses-the King's household and hired Knts. being at the 
40 days at $8 \mathrm{~d}$. per day, would be met by an escuage of $2 \mathrm{~m}$. per fee, upon which it may be wages of a observed, (a), that the duration of service $t$. Hen II. Knight, $t$. Her. (ut videtur mihi), is not clearly proven; (b), that $8 \mathrm{~d}$. might perhaps on the average defray the daily cost of a miles, 2-3 horses, and an attendant or attendants; $(c)$, that it would seem to leave no surplus for casualties-e.g. loss of horses, and expenses to and from the place of muster; and (d) that $2 m$. is the highest scutage, and $8 \mathrm{~d}$. the lowest wage $t$. Hen. II., I $m$. and Is. (wage) being also recorded. Further the conventions between Hen. I. and Robt. Earl of Flanders (I IO I-3) Flemish demonstrate that not only did the King agree to Conve pay journeys to and fro, find board and food $t$. Hen. 1 . (ut credo, the equivalent of the customary wages), but also to defray all losses, as was customary with the milites of his own household: in addition the Earl was to have an annual retainer of 400 marcs, for 1,000 milites in England (in case of need), for an undefined period, each miles to bring 3 horses.* The editor of the Red Book Exch. (L. R. vol. ii.) rates the expenses of Knight Service at $3^{c e}$ the escuage, but $u t$ supra, no proof

Crown's risk as to losses, and in some cases (at any rate), wearing the royal livery, but it seems clear that the liabilities to losses from service by tenure would be taken by the tenants themselves.

* Fadera; 500 milites in $110 \mathrm{I}$, and $I, 000$ in 1103 ; see also Pipe 31 Hen. I., where is some sligbt evidence for supposing the wage of a Knight in a Castle to be $4 \mathrm{~d}$. a day (p. 137 ut sup.), and vide Cbron Pet. App. (p. 175) where Vivian (t. Hen. I.) ought to be a miles in exercitu cum ij equis, et suis armis, et abbas inveniet ei alia necessaria. 


\section{IOI Domesday and Feudal Statistics}

(under correction) of time has yet been advanced as to the earlier period in England; Prof. Maitland remarking this has given the useful reference to a certain term (Rot. Cl. I 4 John, p. I I $7 b$ ), but at the same time it is to be allowed that

Term of Service. guard (Wales) 2 days later: in this expedition tions.

Army of Ireland, I2II. 40 days is not infrequently named in connexion with small serjeanties and the iurati ad arma, and clearly for Knight Service in Normandy $t$. Hen. I., (Bp. Bayeux' fees). Nevertheless it seems almost demonstrable that in I 2 I I (I 2 John) certain feudal tenants served far beyond that period; the royal army being at Pembroke, I 6 June; Waterford, 20 June; Dublin, 24 August; and Fishthe Ist general prest to feudal tenants was made at Pembroke, I 6 June, and the last notable ones at Dublin, 2 I August, to some 332 milites, and to c. I 6 more next day : altho' many of these advances (to milites) are indefinite, some, up to the close of the period, are stated to be on their demesne (or that of their lord), - in the case of Flemish Knights, on their fees. It may be remarked that Earl David (Hunts) had an advance (prest) as late as Aug. 24, and that in I4 Hen. III. (Bain's Scotch Cal. citing L. 'T. R. Mem.) his successor Earl John accounts for and is pardoned $f^{80}$ of the prest of Ireland $t$. John-the former Earl had 10 milites in the Irish army, likewise the Earls of Hereford and Essex (the Justiciar), but this is the highest number there recorded :* in

* It should be scarcely necessary to observe these Earls had more than 10 fees each-prests occur in the Pipe Roll 31 Hen. I. as being accounted for at the Exch., and it is 
the reigns of Ed. I. and II. it is certain that 40 days is the accredited term, and appears to 40 days. have been in 50 Hen. III. (Pat. Rot.) when 5 northern Barons are acquitted of further service on that ground.

The Inquisitions of Normandy (I I 77-I I 89) Normandy perhaps show a service to the King of $c .652$ fees tions. from a total of c. $I, 830$ fees [the record gives $58 \mathrm{I}$ from $c$. I 500,] some of the royal service being in castleguard-in either case about a third of the total, the balance presumably serving in nummis, and guarding the baronial castles, which in a certain sense are those of the King and Duke [Hen. II.]: the earlier return of the Bishop of Bayeux is similar, 40 knights doing service 40 days (to Hen. I.), for I 20 fees. *

The massed capital (c. I 400) and undertenants $(7,87 \mathrm{I}$, Ellis), in D. B. yield 9,27I in toto; of these most of the immediate and many of the mediate ones can in no sense be regarded as holding by Knight Service: the number of milites Milites in (Ellis) is 137 , but this is a most delusive return; Domesday.

clear that some had been made to English milites for the army of Normandy, 2 Fobn (Rot. Canc. 3 John).

* The whole service due to the Duke is here stated as 774 milites [Feudal England, p. 292, citing date as 1171 , and Liber Rubeus, vol, ii., p. 647, under date $c_{\text {. }} 1133$, noting that the total (774) is not in the original], but this seems to have been an error of the transeriber, produced perhaps by adding the service $(c .652)$ of $t$. Hen. II. (including the Bayeux fees) to the latter total (120) t. Hen. J.: it may be noted that the Bishop had 120 fees at either date ad servitium suum, and is returned as owing 40 milites to the Duke $t$. Hen. I., and 20.t. Hen. II. 


\section{I०3 Domesday and Feudal Statistics}

as "Knights" occur also amongst the capital and undertenants : there are certainly upwards of 700 (it is impracticable to distinguish duplicates) men, to whom D. B., directly or indirectly applies this term (and many more of course of the class, not specified otherwise than by the baptismal or gentilitial names), but some of these are in no sense of the term "Knights," as obviously the domince do not militate, nor presumably does Wennenc, the priest [D. B., i., I $8 a$, bis vel amplius], included (I think), amongst Earl Eu's milites.

The term therefore in its collective usage may include mere tenants by military service, who cannot be "Knights"; the same application is often to be remarked in the Baronial certificates (including domina, monachi, etc.), of I I66, which yield some 4,000 names, $\frac{2}{5}$ of which hold less than I fee ; some of these are entered more than unce, and on the other hand the returns are neither definite nor complete: Simon de Beauchamp's charter names 85 tenants on $36 \frac{3}{5}$ old fees, and if read (by the letter), Auxilium, informs of an aid on the fee $t$. Hen. I. (i.e., scutage t. Hen. 1. in nature, if not in name), - that all his tenants were milites $t$. Hen. I. or $t$. Hen. II. is improbable.

The Assize of Arms* (I 18I) ut videtur mihi, affects for the more part tenants by Knight Service;

* It is presumed that few tenants other than military, and townsmen, would $t$. Hen. II. be assessed at 10 marcates of land or goods; the exceptions perhaps would be tenants in fee farm, retainers attached to important households, and perhaps a few tenants by socage on the ecclesiastical estates, allowing always for considerable intermixture of tenure. The Assize $t$. John, names tenants of $\frac{1}{2}$ fee, [some of them perhaps equestrian servientes]; most of the Yorkshire subsidy men 


\section{Feudal Statistics}

I 04

(a), I fee or more; (b), I6 marcates of land or Assize of goods-say $\frac{1}{2}$ fee; $(c)$, Io marcates of land or $t$. Hen. 11 . goods-say $\frac{1}{3}$ fee; $(d)$, all burgesses and tota communa liberorum hominum allowing $(d)$ to include those holding other than by Knight Service, and in exceptional cases $(b)$ and $(c)$, and supposing the above classes to furnish the cavalry and heavy armed infantry $t$. Hen. II., and that the villani were not to be permitted to have the furniture of freemen.

The author of 'The Art of War lays much stress on the absence of bows and arrows, which is little Alleged to the purpose, as the assize $t$. John (vide Rot. Cl. Archery. I4 Hen. III., p. I, m. $6^{\mathrm{d}}$ ) is quite definite on that point - in addition, these weapons are named in the Laws of Hen. I., and it is incredible to hold that the community of chroniclers of divers ages had entered into a pact for a systematic deception of the moderns on that head, and vide also Pipe Rolls $t$. Hen. II. as to archers and arrows.

Ordericus V'italis mentions feudum militis as Feudum quite early in the I Ith cent., thus, Prefatus militis of Decanus ex discipulis Fulberli Carnotensis Epis- $\begin{gathered}\text { Irth } \\ \text { century. }\end{gathered}$ copi fuit, et ex paterna hereditate feudum militis possedit with reference to Dean Fulc, whom he terms silicernius $t$. Mainerius ( $1066-1089$ ), and further (as to military ecclesiastics) continues, Deinde Presbyteri de stirpe Dacorum litteris tenuiter edocti parrochias tenebant, et arma ferentes laicalem feudum militari famulatu defendebant - whether or not the Dean of Evreux was classed as a miles

[25 Ed. I., No. 16, Yorks Rec. Ser.], are rated at less than 20 s. of goods, but it is allowed that medixval assessments are of a formal nature. 


\section{I05 Domesday and Feudal Statistics}

is left indefinite; but certain it seems the feudal tenure of Normandy, as portrayed by that author, was the antecessor of that introduced into England. Milites of Just as some of the milites of D. B. and I I 66 Peterboro", are demonstrably and presumably not "Knights," so also in the return of the milites of the Abbot of Peterboro' (Chron. Pet. t. Hen. I.) occur sochemanni et serviunt cum militibus, but it would be hard to credit their appearance as "Knights" habentes equos, et loricas, et cassides, et clypeos, et lanceas, in exercitu, tho' they might very well serve in nummis.

Without falling back on the writ described as Service of startling in Feudal England (p. 303); the writ, Abbey, in exercitu. p. 304, ibid., and also in Ellis' Introd. to D. B., vol. ii. (p. 447, ed. 1 833) in which the Abbot of Evesham is ordered to lead 5 milites [in his charter $4 \frac{1}{2}$, and $\frac{1}{2}$ fee new ; returns $4 \frac{1}{2}$ fees for scutage (aid) I 4 Hen. II., and $38 \mathrm{Hen}$. III., and recognizes the service of as many in exercitu, 5 Ed. I., and $4 \mathrm{Ed}$. II.], there is no refusing* the conclusion

The pre. decessor of Ranulf Flambard disseised for defect of service, etc.

* The statement that Ranulf Flambard (Bp. Durham), devised feudal service, can obtain but little beyond our halls of learning, for his predecessor temporarily lost that Bprick (1088), in that, after oral summons he withdrew himself, and his milites, in the King's necessity, etc.: this was $\mathrm{Bp}$. Wm. sancti Carilefi [the American Plac. Ang. Norm., ed. I 879, cites the case, giving reference, but not identifying the prelate, but vide Simeon of Durham], whom Lanfranc proposed to treat after the manner of Bp. Odo $t$. Wm. I. Indeed strictly contemporary evidence (Hist. Eccl. Dun., written there) renders it clear that $\mathrm{Bp}$. Walcher's neglect in restraining his milites led to his death in 1080 : it may be suggested that A.S. history would yield a more suitable range for the $r$ magines Historiarum of the romantic school, as furnishing for speculative genius a scope both ample and comparatively secure. 


\section{Feudal Statistics}

I 06

that certain capital tenants enfeoffed milites $t$. Wm. I., and hence themselves had been infeuded for their homage and service.

This is of course not to say that Wm. I. had generally enfeoffed his military tenants by the service of bringing all their milites to his armies in England and Normandy, for, the office of holding the former by maintaining his castles, and those of his barons seems to have been a more essential one : and, that the servitia debita were divers [tho' Diversity uniform as far as regards escuage and aid_-saving of Services the small fees of Moreton], is plainly to be discovered both from the Norman Inquisitions [ $t$. Hen. I. and Hen. II.], and the English Baronial Charters [t. Hen. II. reflecting Hen. I.]. Exactly what pacts (if definitely expressed) were made with the Conqueror's Barons can be but a matter of speculation,-but there is no particular improbability in supposing that a tax on the fee then existed, and that the "Knights" in exercitu were supported by the contributions of their compeers, and others, who did not militate. That the vague service in exercitu due to the Crown was on a more ample scale $t$. Wm. I. to Hen. II. than Hen. II. to Ed. II. is highly probable (tho' no particular information is available till Hen. I.), but it should be borne in mind that the majority of lay tenants of I 66 (or by their ancestors), had been feft post $\mathrm{Wm}$. I. - owing to the forfeitures of the earlier barons.

Thus the fief of Moreton* escheated at the com-

* This fief would have been "good cheap" at a service of 500 , according to the measure of the A.D. $1166-8$ entries, and the above eery incomplete analysis shows $c .350$ fees, hence 350 


\section{Domesuay and Feudal Statistics}

Partial mencement of the reign of Hen. I., and from it analysis of Moreton Escheat.

arose very numerous capital tenants, to all appearance, ut de corona; thus, Earl Reginald in Cornwall (c. 2 I $5 \frac{1}{3}$ fees), succeeding Wm. f. Richard, whose father may have been the Earl's undertenant in D. B. ; Ric. de Aquils. (35); Galf. Martell $\left(7 \frac{1}{2}\right)$; Bern. Pullein (I); Wm. $f$. John de Harpertree; Wm. $f$. John ; Ric. $f$. Wm. ; Nich. $f$. Harding; Ric. del Estre; Walt. Brito (15); Ro.

or 500 or more milites led by the Earl of Moreton to the musters of Wm. I. - the nos. almost alike improbable. It may be observed that the serqices (to scutage), $t$. Hen. II., were approximately in total on an equality with the infeudationsthe current theory therefore involves all the "Knights" (say 6,000-7,000) being present in exercitu: yet the Roman de Ruu (lines 1 1,253-9, and Feudal England, p. 260), makes Wm. $f$. Osbern (certainly not with the approbation of his compeers), offer to double the chevaliers for the expedition to England (1066), - that the barons could easily have so done is not Evidence improbable, as by the Norman Inq., $t$. Hen. II., the figures of the Roman de Rou. of which by no means reach Wace's [he names 20,30 , and roo chevaliers to become 40,60, and 200]. The Roman de Rou [lines $11,364-5]$ cites Duke Wm. as setting his baronage an excellent example of evading feudal obligations to his lord,

\section{Petit sert mais meins servira \\ Quant plus ara meins vos fera}

to be compared with the tam parvam fortitudinem hominum secum adducet quam minorem poterit ita tamen ne inde feodum suum erga Regem Franciae forisfaciat of the Dukes of Flanders in the already cited conventions of 1101,1103 , and 1163 , and the ten ( 1103 ), and twenty ( 1 I 63) milites to the assistance of the French Kings as service, whilst to the English ones, 1,000 and 500 "Knights" can be furnished (for cash down). What is recorded of the Conqueror's lay Baronage either in England or Normandy very little suggests they would rigidly conform to any fixed and definite military obligations in exercitu,- the diminution of the army service of $\mathrm{Bp}$. Bayeux from 40 ( $t$. Hen. I.), to 20 ( $t$. Hen. II.), has already been remarked. 


\section{Feudal Statistics}

Beauchamp (I 7) ; Hen. Lupel (I 8) ; Wm. Fossard $\left(3 \mathrm{I} \frac{1}{2}\right)$, presumbably the successor of Nigel Fossard,* Earl Moreton's Yorkshire undertenant; and many others, including the Honor of Berkhamstead retained in the hands of the Crown $\left(22 \frac{3}{5}\right.$ fees $)$, - it seems clear enough that all these servitia delita are of $t$. Hen. I., and have no very direct connection with the number of milites Earl Robert led to the Conqueror's musters, tho' perhaps in some relation to the "Knights" that had been enfeoffed, and the pecuniary assistance they could render.

The charters of Earl Hugh and Wm. de Albenia Early (Pincerna) are good evidence to demonstrate early subinfeudalay systematic enfeoffments on an ample scale, by tenants. the unit of Knight Service; for Roger Bigot departed this life in I 107 (Vitalis), or I 108 (Hoveden), $\uparrow$

* The Fossard fief in the Baronial Charters (1166) is entered under Suffolk, but is essentially a Yorkshire one, and so answered in the Pipe Rolls: a few of the tenants named were capital tenants (apart from the fees of Moreton), thus Nich. $f$. Harding, whose ficf of Meriet had been held since Fees held the acquest of England [T. de $N$. ; also in D. B.], but very since the few of any minor capital tenants of 1166 can be traced to Ecquest o D. B. : of these Rog. de Berkeley is one, but part of his holding had been at fee farm, part under his reeveship, and but a minority by possible Knight Service. The fief of Belet [1210-1212; vol. ii. L. R. p. 545] is clearly that of D. B. [i. 84a], and is rated as I fee in I I 66 [debet servitium $j$ militis], but the Wm. Belot of 1086 [ut sup.], is returned amongst the sereientes regis-I do not suppose that one in 100 of the numcrous thanes and servientes of the King (1086) could be traced as capital Crown tenants 1166 , by knt. service.

$+V i d e$ also Florence of Worcester, from whose Chronicle it descends to Rog. de Hoveden. 


\section{Domesday and Feudal Statistics}

Duke

Richard's military setvice.
Subinfeudation, t. W'm. $/$.

before which he had feft to the extent of I I 5 fees [vide his son's charter I I 66] - likewise before the death of said Roger, his son in law (the said Wm.), had of the gift of Hen. I., I 5 and Io fees already subinfeuded [vide his son's charter I 166]; in addition Florence of Worcester (1086) uses the expresssion, quot feudatos milites, referring to $D$. $B$., and tho' that valuable record is no Feodary, it gives the information the chronicler records, tho' not in so ample a manner, as would occur in a specific return of Knight Service.

The Exon. D. B., the $I . C . C$., and $I . E$. (ed. Hamilton), in conjunction with D. B. set early feudal tenure in a clearer aspect: in the latter $[I . E$., presumably $t$. Wm. I., and almost certainly I I th cent.], amongst the list of ploughs (p. I68, ed. Hamilton, and in all 3 of his originals), occurs the following [hitherto unnoticed, ut credo], with reference to the vill of Teusham,*-Hoc tenet iohannes in feudo de abbate pro duobus militibus. Another reference to military service occurs in

Duke

Richard's Military Service. Will. Gemet., of the early I Ith century [accipiens munere comitatum ut inde exhiberet ei militice statuta, compare, in statuto servitio Milicie in the Charter of Hen. I., Lib. El. III.], which (former) is cited more fully in The Scutage and Knight Service of England.†

* Vide D. B., i. I9 $a$ and $201 b$, where the lordship of the vill is divided between the Abbot of Ely and John $f$. Waleran, perhaps the same tenant as in I. E., ut sup.

$\dagger$ The reference to $W m$. de Fumieges was made known to writer by this work (J. F. Baldwin, Univ. Chicago Press, I897), which is well deserving the attention of all-interested in the 


\section{Feudal Statistics}

Feudal System-either in America or England : there are A recent (and it can scarcely be otherwise with a vol. written so far American from original sources) many demonstrable errors, and also a work on rather too conspicuous tendency to combine the opinions of System. English writers (named). But the subject has been well laboured from printed works, and the author, having a clear conception of his own views, is intelligible enough to the reader : a certain well known bistorical method, is to attempt to consign to oblivion, all intrusive works, at the same time quictly making use of their references (occasion arising), as suitable novelties. There is another citation of servitium militum (t. Wm. I., p. ix., ut sup.), and should his occasions permit, it is to be hoped, this writer will continue his investigations in English History, for readers both of his own, and this country.

It is not, of course, to be inferred that the mere fact of A magnum residence on a Western continent confers a particular im- opus on munity on historical writers, for I would not suppose that, Britain. even the most ingenious of our own artificers of History could hope to surpass, and scarcely to equal, Ancient Britain in the light of modern Archceological Discoveries. This magnum opus states that "albeit the true character of the false Saxon Extracts chronicles have (sic) been frequently exposed, they still con- from, and tinue to colour our popular histories, and to injuriously affect sesign of our national policy" (p. ix); that its design is "to restore to the pages of British history those circumstances of which forgery and imposture have deprived it, and which archæology has found safely preserved in the pure bosom of the earth" (p. x); that the $A_{0}$. $S$. chronicles are "patched forgeries of the eleventh or twelfth centuries, probably done in Rome, and wholly unworthy of credit" (p. 74); that "ancient trash piled ... accepted by the modern world as the groundwork for a history of Britain and the construction of its national policy" (p. 74); that "so far as books go, the Sacred College of Rome had the entire making of European history ... until the invention of printing put an end to its monopoly" (p. 180); that Beda's information concerning the AngloSaxons "was hopelessly wrong and defective" (p. 73), and terminates by bringing "to book" "the theory" of Beda (p. 181). 


\section{Iogb Domesday and Feudal Statistics}

Now be it obscrved that a certain grandeur, and magnificence of language (well enough adapted to exploit the discoverics of Professors of the Arts of Graphology, Phrenology, Palmistry, ctc.), is in itself no proof absolute of thcir author's lack of more real attainments; such is apt, in the mind of certain readers, to raise a curiosity as to the fulfilment of expectations suggested by a platform of premiscs so great. Now it is at once allowed that even from the most pretentious, and least solid of books, some useful information may issue, but whatever success "circumstances" "safely preserved in the pure bosom of the earth," might or might not have in refuting "the false Saxon chronicles," such are (in Ancient Britain, etc.) ncither cxposed, nor digested in a manner calculated to afford (at lcast to the tenuiter edocti) any proof of their existence (as on $\mathrm{p} . \mathrm{x}$ ) ; that is, the author does not favour his readers with that special access to their* repository which himself must be presumed to have.

The ancestors of the English brought with them "the polytheism of the Mongolian steppes" (p. 53), and the Romans found in Britain, "the Buddhic polytheism of the Goths" (p. 54), whose "bitter hatred of hierarchical government" was not "an Aryan sentiment, nor a Teutonic, nor a German one," but "purely and distinctly Gothic" (p. 190), so that the hitherto illiterate reader, now rather persuaded of the error of believing his predecessors were of the IndoEuropean race (as he might have imagined), is amply compensated by the possible reward of Chinese originals: as the Gothic sentiment (ut. sup.) is anti-Teutonic, he will naturally be distressed to understand why he, or any other Scandinavian or English descendant of the Goths, should now be speaking a language essentially Germanic-here the author might well come to his aid in revealing one of those secrets of the "pure bosom, etc." (p. $\mathrm{x}$ ) to which he alone has so easy an access.

Formation. The A. S. chronicles doubtless took their present form of $A . S . \quad t$. Alfred ( $9 t b$ cent.), and are in hands of the 9 th to the 12 th Chronicles. cent. (the last terminates in II 54 , but most of the writing would seem to antedate 1066, the French form of letters of

* Sc. the interred, and now disinterred, "circumstances," a notional meaning, and exact particulars, of which are so difficult to attain. 


\section{Feudal Statistics}

the I1th cent. being notably different from those of Saxon England), bcing compiled from Beda, and presumably cmbodying divers local memoranda: the existence of such for Northumbria, 732-801, can easily be demonstrated by drawing The out the provincial entries from the Northern Annals (praised for Symeon of Durham), and by comparison with the National Chronicle, the consistent and more complete notices in the Annals of former (or rather its original, or originals), evidently having furnished the more slender items in the latter. It is not easy to see why the "Sacred College" (p. 180) should have wrought essentially heathen pedigrees for the $A$. $S$. kings in the Chronicle; it is still less easy to understand why the statements of contemporary historians are usually* confirmed by records, Chroninor how the works of Matth. Paris and divers nthers con-clers. taining matter extremely hostile to Pontifical authority could escape the censorship of said College-it, it may be repeated, is difficult, but not impossible of explanation to one having a source of authority - "the pure bosom, etc." (p.x)-unhappily denied to ordinary mankind.

As to English events in Britain prior to the time of Beda, it may be remarked that learning reached the North from IntroducIrcland $6.56 j$, a few years after the reputed landing of the Ist King of Northumbria, prior to which, let it be supposed, Runic letters would not be unknown in England : a chronology of the authentic Kings of his province, is appended to a copy of Bede (the writing praised for the 8th cent.), and traditional predecessors of the royal houses might well be handed down tion of I earning in the North. Royal Genealogies. in the verse of Scalds (even, if not in writing), their authenticity of course not being alleged.

In the vol. under note the Suevi appear as a Slavic tribe Gothic and (p. 138), a Gothic or semi-Gothic one (p. 193), where also, Germanic. as of the "Sacre or Goths of the Euxine and Baltic, the Gotbones of Tacitus," so that it would appear that Goths and Sclavs were all one; without, however, attempting to determine whether the author's authority on the ethnology of the Suevi derives from inspiration, or exhumation, it may be stated that Gothic and Germanic are often used (not in Ancient Britain, etc.) as terms interchangeable, but perhaps the most convenient modus is to include Scandinavians, Angles, Saxons and Deutschen under the term Germani (the Germania of Tacitus is of course not the present German Empire, and

* No particular accuracy for dales, nur correciness in matlers statistical, is here suggested. 


\section{logd Domesday and Feudal Statistics}

Bcda counts as Germani Angles, Saxons, Frisians, Danes, etc.), and to consider the Anglo-Saxons akin more particularly to the Norse [leaving open the question of whether or not Angulus was part of 5 th century Scandinavia* $]$, rather than to the inhabitants of the Empire to which Charlemagne succeeded. To class Norse, Angles and Saxons as Goths of Mongolia, and the Deutscben as Germans and presumably (p. 190) Aryans, has certainly the advantage of novelty, and needs but some trifling explanation [as that Confucius had, with considerable foresight, instructed the Gothic races (prior to their emigrations), in the speech of Germany], to become impregnable; doubtless, by an oversight (not altogether irremediable) the learned author has omittcd to supply from his often named, and particular repository, this necessary explanation (for a dull reader), as to language.

Goths,

Gute,

Gothones,

and

Sothini.

Dani,

Suethans, and

Suethidi, not necessarily Gothic.

Angli and

Suevi;

their loca-

tion.

Regnar

Lodbrog in

English

History,

A.D. 870 ;

his speech

under-

stood.

Deficiency

of the

Collection

of the Mon.

Hist. Brit.

as to early

evidences

of the

English

races.

* How to apply and limit the term Scandinavia, 5th cent., is beyond the power of the writer to discern, but it may be observed that the earlier writers make no mention of Goths in it, unless indeed the Guta. (see p. $100 j$, and for further illustration) of Plolemy are held to be such : at the same time that author (whose Geography, praised for A. D. I20, seems sometimes to antedate Tacitus) locates the Guthones (within the Venedi) in Sarmatia,-apparently the Cothones of the Germania, who live more under the constraint of monarchy than the other Germanic gentes. The Gothini of Tacitus, who pay tribute, and work the iron mines, were not far from the Danube; now certain it is that fornandes (c. 552) derives the notable Goths (who overran much of $\mathrm{S}$. Europe

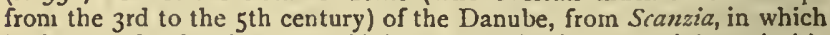
he locates the Suethans, Suethidi, and Dani (who also originate in it), whereas the classifications of its inhabitants by later writers, render it particularly doubtful that any Goths had more than mere settlement in certain parts of Scandinavia. Both King Alfied and Beda consider the Danes as Germanic, and derive the Angli from the Schleswic district, whereas Ptolemy and Tacitus agree in esteeming the latter, as of the Suevi (cf. p. rogj) a gens noted by Crsar, and occupying about the Elbe, $t$. Strabo (c. A.D. 30), and at the time (c. A.D. IOO), of the two above-named writers, the former of whom (Plolemy), does not locate the Angli on the actual coast (the Saxones, for one, on the neck of the Cymbric Chersonese cut them off), as does the latter (or near it, - the island, etc., Germania, 40): besides the evidence for esteeming the Scandinavians to be also, to a great extent of the Suevi (see p. Iogj), the St. Alban's Chronicler (praised for Rog. Wendover, and Matth. Paris), using some unknown Passio of St. Edmund, nanes the likeness of the Danish to the Anglian speech, in the converse of Regnar Lodbrog, with the King and Martyr (in anno 870). The Mon. Hist. Brit. (a work laborious enough) concerns itself, at some length, with notices of the early inhabitants of Britain, but although produced at the common charge of the English is singularly deficient as to their originals, a line of investigation which might have been esteemed just as pertinent, as a collection relating to Roman subjects; this (some illustration of the Germanic races who settled in England as Angles, Danes, Norse, and Saxons), the present writer hopes to essay (occasion permitting) as an introduction to $A$ History of Northumbria. 


\section{A NOTE ON THE AGRICULTURE IN TACITUS' ACCOUNT OF GERMANIA.}

Tacitus' (born C. A.D. 40 to '56) wrote his account of Ger-Tacitus' mania, C. A.D. 98 ; dismissing the question as to the exact Germania. value of this author's information, and gathering data from the whole of his short work, it may be observed that although some of the gentes noticed are under more or less despotic rule $(25,43-5),{ }^{*}$ many exist as communities enjoying and appreciating a considerable degree of liberty ( $\mathrm{I}, 37$, cf. 45), under reges $(7,1 \mathrm{I}, 43-4)$, or principes (I I, I5, 22). The Germanict tribes appear to have dwelt in villages (vici, I6), their ranks being composed of nobiles $(7,25,44)$, ingenui $(20,25,38,44)$, liberti $(25,44)$, and servi $[24,25,32$ (familia), 38, 44, 45]: a difference between the warriors and actual cultivators of the soil is apparent (14, 15, and perhaps 26), the principes [who maintain a retinue (comites, I3, I4), averse to the labour of husbandry (i 4$)$ ], receiving a voluntary tribute of cattle and grains (armenta and fruges 15), suppose for consumption. The distinction is by no means so clearly marked as to enable the statement that zuariors and cultivators are terms inconvertible; but the bravest of the former class are depicted as leaving the care of the fields (agri, 1 5, cf. 26) to the women, aged, and infirm of their households; these (latter) are presumably ingenui rather than servi.t The plebes (II) include the ingenui, and perhaps the liberti; the reges and principes appear to be of the nobiles $\left(7, \mathrm{II}_{1}, \mathrm{I} 3\right)$; and the duces (7) not necessarily above the rank of the ingenui: no

* The bracketed nos. refer to the divisions of Tacitus' text.

+ Tacilus does not consider all the tribes he names as Germanic ; of those he names as such, no comment as to origin is here made.

$\mp$ At any rate in section 15 . 


\section{Iogf Domesday and Feudal Statistics}

permanent property in land exists $(26)$, but in its products (26), and in servi, household goods, farm stock, armour and horses $(5,12,18,32)$. That the latter $(12,18,32)$ were used in Husbandry is not made apparent ; oxen (boves, 18); herds (armenta, 5, 1 5, 21) ; flocks* (pecora, 1 2, 21, 25), and of course cowsi [tho' indirectly (23)] are named: the food of the gentes includes fresh meat (23), cheese or an approach to it (23), and grain stuffs ( 15,16 ), - the common drink is beer or its antecessor (23), and those tribes nearest the Rhine buy vinum (23). Of crops, Tacitus distinctly mentions wheat (frumentum, 23, 25, 45), barley (hordeum, 23), and, I think, uninclosed meadow (pratum, 26), noting an appreciation of the winter, spring, and summer seasons (26): as horses are used in warfare, cattle for consumption, oxen for the plough (iuncti boves, 18 ), cows for breeding and milk (23), the Roman writer scarcely needed to inform the readers of his day that oats and hay were known to the Germani, perhaps also rye. In the commentary on Tacitus, in the excellent Const. Hist. (i. I 8), wheat is cited as the only corn crop, a statement having of intrinsic probability little enough; reference to sections 2 (asperam colo); 5 (satis ferax); I 5 (frugum); I6 (receptaculum frugibus); 23 (ex hordeo aut frumento); 26 (seges); 26 (hiems et ver); and 45 (frumenta ceterosque fructus) will demonstrate it to be opposed to the witness of the Roman writer, whose work should always be used to test the interpretations of his exponents. The servi are pourtrayed rather as coloni $(25)$ than domestics, paying their lords a tribute in wheat, live stock, or raiment, their position being somewhat akin to that of our villani ( $12^{\text {th }}$ to $14^{\text {th }}$ cent.), though the lord of a Manor would not usually have been able to kill, or strike his villein with impunity $(25)$ : the land occupied by the servus would presumably be regarded as the property (for the time) of the dominus,--as a kind of rent is paid therefrom, the slave in a certain sense worked for his lord, even supposing he never cultivated the fields more particularly

* Pecora, not necessarily flocks, but (2I) armentorum ac pecorume seems to require some meaning other than herds.

+ Lac concretum; even, if not the produce of cows, boves and armenta compel their existence. 


\section{Agricultural Statistics}

set apart for the household of the dominus. There are no mediæval Manors, no theories of the mark, nor of the $I 2 O$ acre system; there is nothing (ut uidetur mihi) to be adduced in demonstration of 2 or 3 course shifts, nor (ut $(r e d c)$ is there any decided negative of rotations; there is ample testimony $(4,14,15-17,22,26,45)$ of a general aversion to labour, wastefulness of Agriculture, and abundance of land (agri). Section 26 particularly relates to Husbandry; in it I understand Tacitus to remark that the arable, meadow, and grass fields of the Germans are occupied (or put to profit) by all, in their respective villages to an extent regulated by the number of actual cultivators (agri pro numero cultorum ab universis in vicis occupantur), supposing that all signifies each free household, and that a husbandman, free or the contrary, is indicated by cultor, rather than an inhabitant, and that should in vices be the true reading,* the sense turns on alternate periods of labour for individuals: the conclusion of the sentence (quos mox inter se secundum dignationem partiuntur) - which fields they (the heads of each free household) soon (suppose in April or May) divide amongst themselves according to their dignity (sc. a lord with many servi would naturally need a share much more ample than an ingenuus with a few, or a libertus with none). Facilitatem partiendi camporum spatia prastant follows, indicating that the abundance of land renders partition easy, there being therefore ample sustenance for each individual : this is succeeded by the lines Arva per annos mutant et superest ager, which (ut videtur mihi) implies that the Germans change their arable lands (or some of thens) yearly (by ploughing land out of grass), and (nevertheless) land in grass is left in plenty (owing to the already mentioned abundance): the section closes with further notice of the supineness of the husbandmen, and the amplitude of the soil (amplitudine soli), and a remark that the arable is only taxed with grain crops (sola terra seges imperatur), indicating that beans, peas, etc., were not cultivated. The entire Chapter comprises less than twelve lines, including a thricerepeated statement as to excess of land beyond the immediate requirements of the population : in spite of this particular assistance from Tacitus, the Roman writer has of

* Cf. Cersar (6. B.c. 50), in his a/c of the Suevi : a possible reading would be--frequent changes of pasture, by reason of its superfluity. 


\section{rogh Domesday and Feudal Statistics}

late been credited with statements, whose inconsistencies could : carcely have failed to impress the well informed readers of his own day. In one version the word mutant is supposed to refer to a rotation, and ager is rendered fallow* (I know not on what authority); it is clear therefore arva is either equivalent to all the ploughed land, or such of it as is sown, so that Tacitus is constrained to say that $(a)$ the entire arable is in rotation, and $(b)$ a fallow is left, the $(b)$ statement being contained in $(a)$, as the mere fact of a shift denotes a fallow, or else that the land under crop (or some of it) is changed to a fallow', and a fallow is left, which reading is alike elegant and cogent with the other. In another lectio (A. J. Church, M.A., Latin text, 1898 , notes) the word mutant is attributed to a change of occupancy; but certain it is that the mere usure of a piece of ploughed land by either princeps, dux, or ingenuus in turns has nothing whatever to do with the relative abundancy of the fields other than arable (here agri), the above version leaving the rest of the sentence connected by $e t$ in suspense "betwixt earth, air, and seas," and void of meaning, whereas the ploughing of ley land reduces the ager, for the simple reason that land left from the plough would not be particularly profitable ager for some time to come; further, the alternate occupation of arable presupposes a rotation, and how mere difference of owners year after year on the arva could affect the ager is a mystery that no one (ienuiter edoctus) can hope to explain. It has been stated (supra) that Tacitus does not absolutely negative rotations, but if arva per annos mutant requires the rendering that all the arable is changed p.a., the ploughed

* If it is held that the change implies rotations which include fallow, and hence a diminution of the grass land (ager), this would nıark a contrast between a nation using no, or not so much bare fallow, and one accustomed to some, or more of it, and hence relative extravagance of Husbandry: at the same time the latter would not change their arable (as with 2 fields in a 2 course shift both would be arva), but merely its cultivation; further the literal rendering of the words arva per annos mutant (an actual change of fields), is full of meaning, whereas ideas read in, to support theories (e.g., they change their fields amongst themselves, or change the crops in their fields, or change their arable from crop to fallow) are rebutied as well by the context, as the inconsistencies they involve.

† Arva seems to denote the entire arable (whatever was "ered "), rather than only that portion sown; and a possible, but improbable, reading might be formed by limiting arva to sceded arable, and by supposing the Romans made little use of bare fallows-rendering ager as land not under the plough. 
falloze of a 2 or 3 course shift is of course impossible; the Roman writer perhaps did not intend a remark so entirely definite, tho' it must be allowed he pourtrays the husbandmen as very little patient of labor, further than the necessities of the times render expedient. The absence of landownership is well explained in Tacitus, and it seems perspicuous enough that a division of the earth's products could be more suitably arranged towards hay time and harvest : it does not seem to follow that the partition, when made, was necessarily in proportion to the number of the actual tillers of the soil in autumn and winter from each free household, as the warlike occasions of the gentes would disturb such an arrangement, and the princeps and his comites, (who seem to foreshadow the feudal systemi might be generally allotted a return out of proportion to the contributions to the labor of husbandry made from their households, in addition to the voluntary tribute already cited. 'To bring into the sketch the medixval system of agriculture as to rotations and ownership, the text of Tacitus scarcely permits; any sort of settled property in the arable nullifies the word mux, as the writer would scarcely expect the critics of his day to believe in divisions of property whose descent, tho' not successive, was already defined by alternation. These tribes include the Angli (40), who may have been the ancestors of the race Angli and of the same name, who afterwards settled in England; those Suevi. of Tacitus belonged to the Suevi, and appear to have been one of the freer communities: English and Scandinavian traditions unite in representing the later Angli as deriving from what in historic times was Denmark, rather than Germany, but both countries are of course included in Germania ( ${ }^{\text {st }}$ cent.). The exact ancestors of the modern Scandinavians*

* Fomponius Mela (c. 45) names the island [always so till the 6th Early century, at least, and of unknown magnitude] of Scandinavia, as yet notices of held by the Teuloni: Fliny, the naturalist (c. 79), says part of it, Scandicontaining 500 pagi, was held by the Hillevioni, noting also the islands navia. of Scandia, Dumma, Bergos and N'erigo, from which (latter) the voyage to Thule is wont to be made: Solinus Polyhistor (c. 80) mentions Scandinavia, as the largest of the islands of Ciermania: Tacilus (c. 98) places the Suiones [this term recurs in Eginhard (c. 820) as applicable to Swedes and Norwegianc, and in Adam of Bremen (c. 1077), who 


\section{Iogj Domesday and Feudal Statistics}

Scandi- (t. Tacitus) I have never seen satisfactorily determined; but
navian Englisl. $X$ certain it is that a very considerable proporti $n$ of the inhabitants of England ( $t$. 1086) were of Norse (chiefly Danish) origin, as is witnessed by $D . B$., the old records of Northumbria (which should be read with the A.S. Chron.), and other notices of the Danelaga, in addition to such evidences as nomenclature ; and tho' the Normans were a compound race, speaking a foreign language, it is scarcely to be supposed it was other than the Nortiman element which enabled them to acquire England at that period.

seems to confine it to the former] with a fleet, certainly in the mainland of Sweden, and probably in some of the Danish isles; beyond the Suiones are the Silones (presumably a Finnish tribe, N. of Upsala, and The Angli near the ancient city of Sictona), and here Suevia ends [this writer, he and it observed, classes both Angli and Suiones as Suevi, and calls the Suiones of Baltic, the Suevian Sea]; Ptolemy ( 120 or before) places the Dauciones Suevia; Dani, Dacians, and Gutce. and Gutce in the island of Scandia [whether Danes and Jutes, or not, the Dani are frequently termed Dacians, thus, Gerald de Barri, 12t/2 cent., notes the corruption of the Northern speech by the frequent invasions of Dacians, and Norwegians, and Wm. f. Alan, 1166, owes one knt. in Norfolk at Carlefi, against the Dacians, there being no immediate connexion with a nation on the Danube in either case]: Fornandes (6th cent.) locates the Suethans and Dani in Scanzia (quasi officina gentium) island: Procopius (6th cent.), seems to place the Danes about Lenmark, near the Varni (extending to the N. Ocean, and separated from the Franks by the Rhine); calls Scandinavia, the island of Thu?'e, which he has only visited by the converse of those coming Brittia and therefrom-this is that author who mentions Brittia, as inhabited by the Varni Angles, Frisians and Britons, an expedition by sea of the former, led in the 6th by their king's sister against the Varni (supra); and as well notices of cent. British legaiions, lack of cavalry and horsemanship, navy, marriage Traditional ( $c f$. Tacitus), as various poetical legends: Beda $(c .730)$ gives the Danes kinship of as one of the nations from whom Angles and Saxons derive; and $W m$. Angles, Danes, Jutes, Northmen, Saxons, and Suevi. Malmesburien. $(t .1135)$ makes a traditional ancestor of the $A . S$. king:, first a foundling in the Scanzia of Fornandes, and afterwards a ruler in Slaswic (Haithaby), which may be a compilation from Ethelward (writing 975-1011), who states that Old Anglia was situated between the Saxons and Jutes (Gioti), with a capital town Slesuzuic (Saxonice), or Haithaby (Danice), that Hengist's ancestor was Unothen, whom the Danes, Northmanni and Suevi, worship to this day, citing Lucan (Ist cent.) as to the latter, fundit $a b$ extremo flavos aquilone Suevos, which corroborates Tacitus; and in another passage makes Scef (the son of Scyld), Cerdic's roth ancestor, land on the island of Scani $i$ and become king, whereas in the Beozulf, Scyld Scéfing, is the found'ing, and then king of the gár-Denum (spear-bearing Danes). 


\section{CHAPTER III}

\section{AGRICULTURAL STATISTICS}

"This is an Age wherein to commend or extol an Ingenious Art or Science might be deemed a Needless Labour, especially in a Country so highly improved in everything; but that we find the more Noble, Advantagious, Useful, or Necessary, any Art, Science, or Profession is, the stronger Arguments are framed against it; and more particularly against the Rustick Art and its infinite Preheminances and Oblectations, by the vainer and more pedant sort of persons, despising the worth or value of what they are ignorant of, who judge it below their honour or reputation to take any notice of so mean a profession; that esteem the Country no other than a place for Beasts as Cities for Men."-Worlidge's Proemium to Systemn Agricultura, ed. 1681.

THE fisçal Hide of Domesday contained (or r2o Fiscal often did) I 20 fiscal acres, and the normal Acres.

areal Hide 120 actual ones, which perhaps accounts for the statement that a like quantity was tilled by each plough per ann.- - which is opposed to the common experience and knowledge of any English farmer of arable, and would predicate weather suitable for constant aration; whereas 30 weeks in the year is perhaps a high estimate of the period during which land can be worked, and 40-60 acres may be roughly taken as the present land of one plough. The work on Husbandry derived from the MS. of Sir Walter de Henley (and printed by the R.H.S.) presumes a 3 or 


\section{I Domesday and Feudal Statistics}

2 course shift, of which respectively $\frac{1}{3}$ or $\frac{1}{2}$ in bare fallow; for the former take I 80 ac., for the latter crops 160 ac. (in each case statute), plough once for and twice for fallow; $\dagger$ allow 8 weeks for holy days (presumably including the 3-4 weeks noted in Custumals at the Nativity, Easter, and Pentecost, and the time occupied by the ploughmen on their own holdings, etc.), leaving 44 weeks for unbroken aration, thus

Scheme of Perpetual Aration.
THREE COURSE SHIF'T.

I 80 acres (I 20 ac. in crop, 60 ac. in fallow) at $\frac{7}{8}$ ac. per day ...

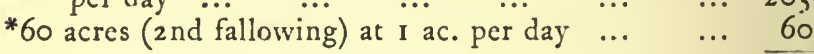

$\begin{array}{lll}\text { Add for Sundays } & \frac{\overline{26} 5 \frac{5}{7}}{44 \frac{2}{7}} \\ \text { Total } & \underline{310} \\ \text { TWO COURSE SHIFT. } & & \text { Days } \\ \text { crop, 80 in fallow) at } \frac{7}{8} \text { ac. per day } & 182 \frac{6}{6} \\ \text { fallowing) at I ac. per day } \ldots & \ldots & \frac{80}{262 \frac{6}{7}}\end{array}$

With Sundays, Total c. ut sup. in either case, the total working out as above, viz., nearly exactly 44 weeks.

The above has been construed to mean that for a continuous period of 44 weeks the ploughmen

Welsh evidence, t. Hen. II.

$\dagger$ Gerald de Barri (t. Hen. II.) remarks the neglect of husbandry of the Welsh, stating they only plough once eacb for wheat and oats in winter and spring, and twice in summerthe husbandman leaving his oxen on occasion of war, whereas the theoretical ploughmen (ut sup.) are depicted as having little existence other than as members of their teams.

* In Canon Taylor's learned paper on "The Ploughland and the Plough," the accomplished writer seems to imagine that (in a 3 Course Shift) either fallow land was unploughed, or that each team ploughed $24^{\circ}$ acres. 
not only could, but also did, plough all day and every day (saving the 7 th), no matter the weather, storms, snow, frost, floods, hay time, harvest, etc.; now if the author means to make this assertion he must be postulating that he conceived his day and generation equally as credulous, as some of the writers on agriculture in the rgth century. The 60,000 knights and fees of King William (apparently still in repute, see "Social England") and the 45,000 parish churches supposed to exist in I 37 I, are errors one can understand, but why such exceeding mystery as to an art daily in operation before our eyes, should appear in the productions of scholars who honor (?) Agriculture with their notice, is not easily conceivable.

Returning to Walter de Henley it may be suggested that he intended to convey that if the above evidently unreal programme took place, then would the amount tilled by each plough in the year be such a quantity of land, as is termed a carucate : in addition the author is supposed to have flourished in the first $\frac{1}{2}$ of the $13^{\text {th }}$ century, and is describing cultivation of demesne land, which it must have been known, was to a considerable extent tilled by the tenantry-this he says nothing about.

Before proceeding to discuss ancient evidences, Agriculture a contrast of the agriculture of 1086,1696 , and 1086, 1696. 1897 may not be out of place; the crops of 1086 and 1897 were *Wheat, Barley, Oats, Rye, Beans, Peas, and perhaps Vetches; of 1696 in ordinary rotation, the same including Vetches; for I 897 add such

* D. B. Wheat 11a, 32a, 176b, Oats $214 a$, Rye $257 b$. 


\section{3 Domesday and Feudal Statistics}

\section{ENGLAND AND WALES (KING) I696.}

Arable at 5s. Iod. per acre ... I0,000,000

Flax, Woad, etc., at 5s. Iod. per acre $\ldots \quad \ldots \quad \ldots \quad 1,000,000$

Pasture and meadow at 9 s.

$$
\text { per acre ... ... ... }
$$

Woods, coppices at 5 s. per acre

Forests, parks, commons at 3s. 6d. per acre ... Heaths, moors, etc., at Is. per acre

Houses, gardens, orchards, etc.

Rivers, lakes, meres at 2 s. per acre ...
Roads, ways, waste land $\quad \ldots$ Average value, 6s. 2d. per acre
1696 ,

Acres.

$\left.\begin{array}{l}1,000,000 \\ 1,000,000\end{array}\right\}$

1897 ,

Acres.

I $2,505,049$

$10,000,000$

$15,122,121$

$3,000,000$

I, 847,$3 ; \mathbf{I}$

$3,000,000$

$0,000,000$

$1,000,000$

500,000

500,000

$39,000,000$
$3,3^{6} 3,28 \mathrm{I}$

$4,480,18$ I

$37,317,983$

ENGLAND AND WALES, 1897 (excluding tidal water and foreshore).

England in acres.

Arable $\quad \ldots \quad \ldots \quad \ldots \quad 11,602,191$

Pasture $\quad \ldots \quad \ldots \quad \ldots \quad$ I $3,191,789$

Wales in acres.

Mountain, heath, etc. $\quad \ldots \quad 2,208,844$

Orchards ... … ‥ 2 I 8,26 I

Woods and plantations $\ldots \quad 1,665,741$

In inland waters, say $\quad \ldots \quad 180,000$

Towns, houses, waste grounds, say $\quad \ldots \quad \ldots \quad 3,477,258\}$ $902,8,8$

I,930,332

I, I 54,437

3,707

I 81,610

600,955

$32,544,084$ 


\section{TEAMLANDS AND CROPS (2I COUNTIES),}

A.D. $1086-1897$.

\begin{tabular}{|c|c|c|c|c|c|c|c|c|}
\hline \multicolumn{2}{|l|}{ Counties. } & $\begin{array}{l}\text { ros6, } \\
\text { Team. } \\
\text { lands. }\end{array}$ & $\begin{array}{l}1086, \\
120 \text { Acre } \\
\text { Theory } \\
\text { Arable } \\
\text { Acres. }\end{array}$ & $\begin{array}{l}\text { r897, } \\
\text { Grain } \\
\text { Crops, } \\
\text { Acres. }\end{array}$ & $\begin{array}{l}\text { 1897, } \\
\text { Vetches, } \\
\text { Acres. }\end{array}$ & $\begin{array}{l}\text { r897, } \\
\text { Fallow, } \\
\text { Acres. }\end{array}$ & $\begin{array}{c}1397 \text {, } \\
\text { Total of } \\
\text { Crops grown } \\
\text { ros6, } \\
\text { Acres. }\end{array}$ & $\begin{array}{l}\text { I897, } \\
\text { Total } \\
\text { Arable, } \\
\text { Acres. }\end{array}$ \\
\hline Devon & $\cdots$ & $7,97^{2}$ & $95^{6,640}$ & $243,16_{5}$ & $3,5^{8} \mathrm{x}$ & 7,675 & 245.421 & 588,639 \\
\hline Lines & $\cdots$ & 5,043 & 605,160 & 560,195 & $9,0 \mathrm{I}_{4}$ & 25,692 & 594,901 & $1,018,886$ \\
\hline Somerset & ... & 4,85 & 582,960 & 98,692 & 3,960 & $3,34^{8}$ & 106,000 & 209,618 \\
\hline Wilts & $\ldots$ & 3,457 & 414,840 & 149.449 & 16,591 & 7.676 & $173.7^{16}$ & 318,719 \\
\hline Northants. & $\ldots$ & 2,931 & 351,720 & 127,234 & 3.918 & $10,5^{02}$ & I $4 \mathrm{I}, 654$ & 213,605 \\
\hline Hants & $\ldots$ & 2,847 & 341,640 & 192,286 & I7, I 59 & I5,898 & 225,343 & 443.759 \\
\hline Oxo & $\ldots$ & 2,639 & 316,680 & 124,096 & 6.836 & 5.477 & 136,409 & 22 \\
\hline Cornwall & ... & 2,377 & 285,240 & 124,504 & 518 & 5,105 & 130,127 & 366, i78 \\
\hline Do & $\ldots$ & 2,303 & 276,360 & 83,184 & 5,260 & $3.67 x$ & 92,115 & 187,108 \\
\hline wick & $\ldots$ & 2,276 & 273,120 & 93.927 & 2,263 & $6,5^{8} 7$ & 102,777 & $168,5 \mathrm{II}$ \\
\hline Bucks & $\ldots$ & 2,244 & 269,280 & 94,439 & $4.37 I$ & 8,564 & 107,374 & 165,001 \\
\hline Berks & $\ldots$ & 2,087 & 250,440 & 106,049 & $6,9.46$ & 9.403 & 122,398 & $202,55^{8}$ \\
\hline Herts & $\ldots$ & $1,7 \times 6$ & 205,920 & 124,894 & 3.937 & 14,007 & $142,83^{8}$ & $218,1 \times 5$ \\
\hline bs & $\ldots$ & 1,676 & 201,020 & 221,693 & 4,687 & 15.341 & 241.721 & 372,765 \\
\hline $\mathrm{Bec}$ & ... & I, 557 & 186,840 & 89,425 & 3,255 & II, 700 & I0 $4,3^{80}$ & 152.574 \\
\hline Staffs & ... & 1,398 & 167.760 & 84. & 1,841 & 1,765 & 87,694 & I73,744 \\
\hline Notts & ... & 1,255 & I 50,600 & 121,300 & 2,492 & 9.780 & 133.572 & 241,092 \\
\hline Surrey & & 1,172 & 140,640 & $57,68 \mathrm{I}$ & $3,5^{21}$ & 8,546 & $59.74^{8}$ & $I_{3} 1,041$ \\
\hline $\mathrm{Hu}$ & ... & $I, 120$ & I 34,400 & 73,863 & 2,225 & 9,275 & 85,363 & $123,53^{1}$ \\
\hline Derby & 1 & 762 & $9 \mathrm{I}, 440$ & 47,974 & 1.303 & 2,570 & 51,847 & 97,602 \\
\hline Midd́l & & & 79.680 & 10,606 & 1,245 & I, 374 & $1_{3,225}$ & $3^{2,955}$ \\
\hline Total & 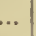 & $5^{2,354}$ & $6,282,480$ & & & & $3.098,623$ & $5,650,425$ \\
\hline
\end{tabular}

N B. - In above 21 counties the teams in 1086 are $43.93^{2}$, i.e.. 83 per cent. of the teamlands; the arable 1897 being 90 per cent. of that in 1086 by 120 acre theory, as above.

ARABLE OF ENGLAND, 1897 ( $1 x, 602,191$ acres).

$\begin{array}{lcccccccr}\text { Grain and pulse crops (all grown ro86) } & \ldots & \ldots & \ldots & 5.780,782 \\ \text { Vetches } & \ldots & \ldots & \ldots & \ldots & \ldots & \ldots & \ldots & 186,604 \\ \text { Bare fallow } & \ldots & \ldots & \ldots & \ldots & \ldots & \ldots & \ldots & 369,254\end{array}$

Acres.

6.336 .640

Green crops (excluding vetches), mostly the food of stock, 1897 ,

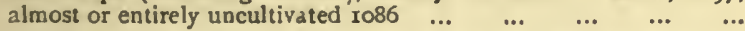

$2,263,879$

Clover, salnfoin and rotation grasses, in arable rotation, partly for hay and partly fed off - entirely the food of stock $\ldots \quad \ldots \quad \ldots \quad \ldots \quad 2,885,863$

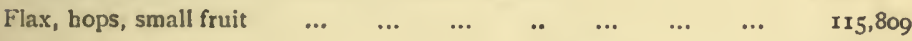
Total $\quad \ldots \quad \ldots \quad \overline{11,602,191}$ 


\section{5 Domesday and Feudal Statistics}

crops as Potatoes, Cabbage, Rape, Mangolds, Turnips, Clover, Sainfoin, and Grasses in arable rotation, so that the present Agriculture is far more remote from that of 1696 , than the latter from 1086, and for aught I can discover there was little of food importation T. R. W. I. or T. R. W. III. For 1086, take the population of England at $1,800,000$ (Ellis' count $\times$ by more than 6 ), and for $1696,5 \frac{1}{2}$ millions (incl. Wales) from King's estimate from the Hearth Tax (also reckoned at 7 millions; the houses were $1,300,000$ at the Revolution, which shows King's cast to have been low); the Lancaster Herald (King) allowed Io million acres in 1696 in ordinary rotation, the same amount in pasture and meadow, allotting to heaths, moors, woods, and forests more than $3^{\text {ce }}$ their now extent, and less than $3^{\text {ce }}$ the present amount of land in towns-a reference to the 1897 Agricultural Returns shows I $1 \frac{1}{2}$ million acres arable, and I 3 millions in pasture and meadow in England. King gives a total produce of $90,000,000$ bushels, of which 17 millions for seed; he estimates $3,200,000$ acres barley land, of which one-third (say I million) fallow, so 'tis plain he is thinking of a 3 course shift, which allows from $6,666,666$ acres under crop, some 73 million bushels for use for $5 \frac{1}{2}$ million folk; this amounts to 13 bush. per head, and between I 3 and I 4 bush. per sown acre yield, (of which about 3 bush. for seed), so that deducting from the sown acres some $1,166,666$ acres for seed, there would be about I acre per head,-in other words some $5 \frac{1}{2}$ millions (of the $10,000,000$ arable) actually feeding the same no. of folk as found. King's estimate of yield is I 3-J4 bush. p. ac. (no items save barley at I 5 bush.) all round; in $1333-5$ from 8 estates of 
Merton College (over I,O=0 acres for 3 years in different parts of England) Wheat yielded 10, Barley I6, Dredge I 4, Rye I I, Oats IO, Peas I I, and Beans so bush., or an average of IO-I 2 bush.; these results have been wrought out from Prof. Rogers' Tables (Hist. Agr.) presumably derived from the actual Bailiffs' A/cs. At this period (1 333-5) varying amounts were sown, but from the figures it would appear that about I quarter ( 8 bush.) might be stated as the all round yield (after deduction for seed); against about 1o bush. in 1696. There seems to be no evidence of yield per acre T. R. W. ; and no reason to suppose the agriculture of the I I th century (1086) much more futile than that of I333-5-hence the statement of a supposed yield of 6 bush.* p. ac. (of which 2 b. for seed) can be supported by nothing unless its author's wish to prove the existence of a fanciful ploughland at any cost (p. 438 D. B. and Beyond).

Now no assertion is made as to the correctness of King's figures, but let it be remembered he was a notable statistician living at the period of the Revolution; that an estimate of $4 \frac{1}{4}$ people per house is less than medium, and that his method or calculating the fallow of the barley area, would suggest that rather more than $\frac{2}{3}$ of the land in tillage was sown.

In 1086 , in 30 counties of England there were

* D. B. and Beyond, p. $43^{8}$, says this hypothesis is taken Average from Walt. de Henley: what that writer actually says is that yield of a yicld of 6 bush. p. ac. means a loss of $1 \frac{1}{2} d$. p. ac., in addi- acre: tion to the land being rent free (suppose 4 d. to $6 \mathrm{~d}$. p. ac.) : in neither the same vol. cited by Prof. Maitland, the anonymous and nor proba cocval writer on Husbandry gives the returns from wheat as bility in 5 times the seed sown, i.e., $10-12$ bush. p. ac., from 2 or $2 \frac{2}{5}$ placing it bush. seed, which yield is similar to the actual figures of the bushels. Bailiffs' a ${ }^{c s}$, ut sup. 


\section{7 Domesáay and Feudal Statistics}

Agricul- 70,606 ploughs ( 8 oxen), with an average of 3.56 tural data, folk as recorded per team; in 34 counties (including, however, most of Lancs. and parts of Cumberland and Westmorland) the recorded population was 283,242 ; assuming 300,000 as the total for the 40 modern counties, and ploughs in proportion then would there have been a total of 84,000 teams; for a moment, allow 120 acres of tillage per plough, then would there have been over $10,000,000$ acres arable in 1086 , keeping alive some $1,800,000$ folk as against a lesser amount (10,000,000 ac.) for more than $3^{\text {ce }}$ that number (i.e. $5,500,000$ people) in 1696 .

Consump- Of the 2,200,000 acres sown to barley (yield tion of Beer. 15 bush. per ac.), King estimates to malt $\frac{2}{3}$ of the yield, i.e., $2 \mathrm{I} \frac{1}{2}$ million bush. (of $33,000,000$ ), to return a total of $12,400,000$ barrels of beer (weak and strong), which allows rather under $1 \frac{3}{4}$ pints per day per head of population, which amount (about 78 barrels) would be produced from $\frac{1}{4}$ of that acre, per head, found by taking the statistics of 1696: a result differing largely from Prof. Maitland's $\frac{1}{2}$ gallon per day for every man, woman, and child, amounting to some $2 \frac{1}{2}$ gallons per recorded man, which princely munificence might well cause the modern labourer to envy his antecessor in the days of King William. Again, take the 2 I counties* whose teamlands are set forth on p. $40 \mathrm{I}$ (D. B. and Beyond), and multiply them by I 20 , with a result of $6,282,480$ ac. arable, against $5,650,425$ in the present decade, of which latter but $3,098,623$ are in the crops of 1086 (the balance mainly being food for stock): and were one to apply 180 acres (Canon Taylor in "Domesday Studies"), arithmetic would he set at defiance 
in some of the shires, whose total area would be unable to furnish the acres required-which result would also sometimes occur if the actual teams (in place of the teamlands) were taken.

How much of the acre per head as thus found from King's tables would be subtracted for stock, there is no material to determine, but Fitzherbert writing t. Hen. VIII. (probably a Derbyshire squire and farmer) does not, if I remember rightly, allow any very considerable proportion of corn for the working oxen. King's estimate for the consumption of Bread, Bread Corn, Cakes, Biscuit, Pastry, Pudding, and all things made of meal and Breadflour is I 5s. $8 \mathrm{~d}$. per head* p. a., and 'tis clear he Stuff, etc. calculates practically all the Wheat and Rye, and part of the Barley, Oats, Beans, and Peas under this item, presumably the produce (by his mode of estimation) of $\frac{9}{20}$ acre, as roughly by King's figures I4 bush. p. acre (rather less) was the yield from some $\frac{2}{3}$ of $10,000,000$ acres under the plough in I696, and as in I 333-5, some I I bush. p. acre (rather more) are found in practice; then should there be, by these figures, some $8 \frac{1}{2}$ million sown acres in 1086 for an assumed population Population of $5 \frac{1}{2}$ millions (as in 1696); but as the popula- of 1696 that tion in 1086 cannot be shown to have exceeded $\frac{1}{3}$ of 1086 . that amount (i.e., about $1,800,000$ ), then would $2,830,000$ sown acres have sufficed, and therefore it is hard to imagine a total exceeding 6,000,000 arable acres, which allows for much of the ploughland being under a 2 course shift, $\dagger$ and some of it

* In the anon. Husbandry (c.t. Hen. III.) farm servants have an allowance of 1 qr. of corn per 12 weeks.

$\dagger$ There is a great deal about 2 and 3 course shifts in Yorkshirc (with reference to gheld rate) in Canon Taylor's "Ploughland and the Plough," the furrows of which systems 


\section{19 Domesday and Feudal Statistics}

in a rotation partly grass, ${ }^{*}$ but counted as arable, which presumably would occur in other counties than Cornwall. Hence some 70 acres per plough would follow, and but three score or less might be calculated if the land in grass (in rotation, and estimated as arable) were excluded; and this amount (6o acres) seems to have been Agarde's estimate of a ploughland in Q. Elizabeth's days. $\dagger$

The well-known Poll Tax Returns 1377, I 379, and $\mathrm{r} 38 \mathrm{I}$ bear on the matter ; the population at

are yet to be discovered by the zealous antiquary, and the rotations identified; these arguments (which seem to have little support from D. B.) appear to arise from certain entries (even better represented in Lincs.), where the jurors roughly Terra estimate the teamlands as in proportion to the gbeld rates; dupliciter ad thus $364 a, 2 \frac{3}{4}$ bovates for gheld, land to 2 ce as many oxen; arandum. 3646 , $13 \frac{5}{6}$ bovates for gbeld, terra dupliciter ad arandum; compare $352 a, 2 \frac{1}{2}$ bovates for gleld, land to 5 oxen, which is similar to the last named, but that it would have seemed singular to write, land to $27 \frac{2}{3}$ oxen; see also $350 a, 351 \%$ (ter), $35 \mathrm{I} b$ and $352 a$ (bis); for cases zobere the teamland equates the gheld $3436,344 b$ (bis), $348 b$ (bis), 350b, 35 I a (quinquies), $351 b, 353 a, 358 a, 362 b$; where the Teamland is half the gheld $349^{b}$; and other simple proportions occur in this county.

Meadow, * Not of course meaning "rotation grasses"; see note, I086.

p. 22 ; also as illustrating meadow, etc., vide D. $B .2 b$; as much meadow as pertains to 10 ac. of land; $38 b ; 46 \mathrm{~s}$. of herbage ; $134^{b}$; land to $\frac{1}{2} \mathrm{pl}$; ; meadow to $\frac{1}{2} \mathrm{pl}$., and 10 . over, a mill of 3 s. and 200 eels, the whole worth 20 s.; $142 b$, Meadow 6s. and $4 \mathrm{~s}$. of hay ; 1436 , Mea. to 3 pls., and $20 s$. over ; $143 b$, Pasture to stock, and hay to farm of Archbp. for 8 days; $156 a$, of hay 10s. ; $183 a$, Of mea. 5 s., besides pasture to oxen; and $376 b$; the men of N. detain $16 s$. of the customs of the pastures.

† A Ploughland, which is about Three Score Acres; p. 10 Aipp. Reg. Hon. de Richmond.

\ For 1377 , refer to "Archæologia," vol. vii., which gives a more extended return than that published in Powell's 
this period seems to have been $2 \frac{1}{2}$ milions or more, Poll Tax and the following figures taken from the detailed ${ }_{1377 \text { and }}^{\text {Return of }}$ returns of Claro Wapentake (Yorks) in I $379^{1379 .}$ suggest omissions :

Per 1,000 of Popu-

lation, Claro, 1379 .

$$
\begin{array}{ll}
358 & \ldots \\
358 & \cdots \\
28+ & \cdots \\
1,000 &
\end{array}
$$

$\begin{array}{lllll}\ldots & \text { Men wed } \ldots & \ldots & 273^{\circ} 3 \\ \ldots & \text { Women wed } \ldots & \ldots & 273^{\circ} \\ \ldots & \text { Over 16, unwed } & \ldots & 453^{\circ} 4 \\ & & & \end{array}$
Igth cent. Model I,, 00 England.

the inference being that many over I 6 years of age were not taxed as they should have been; and further, so far as the imperfect returns at the Record Office (of I 377 for Claro) allow comparison, there were in 1379 found to be actually more folk living over 16 than in 1377 over 14 , which would seem to point to a not altogether extinct desire on the part of taxpayers to escape payment, rather than to any particular catastrophe in that district. The total of I 377 furnished $\oint_{22,607} 2$ s. 8 d. by $1,356,428$ groats from 37 counties from all over I 4 years of age, excluding Mendicants, and the Clergy (about 30,000; see Clerical Subsidy 5 I Ed. III.) ; by allowing for Monmouth, Chester, and Durham, the total population over I4 might be I,500,000. But as what was true of Claro might be applicable to all England (a recorded excess in 1379 of those over 16 , over those over 14 in I 377), it may be reasonable to estimate the $1,500,000$ as over 16 and not over 14. On the assumption that there would be $37 \%$

"Rising in East Anglia," which should also be consultcd for I $38 \mathrm{I}$, and separate clerical subsidies are to be found in both vols. 


\section{I Domesday and Feudal Statistics}

of the total population under 16 , then would there have been 2,380,000 persons in all England; but presuming $35 \%$ of the total population wed (and noting that in Claro of 1,000 recorded, 716 are found as married), then would there be approximately $1,074,000$ wed folk of $1 \frac{1}{2}$ millions as above, which being $\frac{7}{20}$ (taking $35 \%$ of whole community as married) of the total, would bring the population in 1377 to $3,069,000$, so that the true total should lie between these estimates, say some $2,700,000$, called $2 \frac{1}{2}$ millions. Unless the chroniclers are to be regarded as mere relaters of fables, there must have been enormous mortality in

The Black 1 348-9 (the Black Death); given at $\frac{1}{3}$ to more
Death. than $\frac{1}{2}$ the population, so that in the $1-$ st half of the I 4th century the English population might very well be estimated at 4 millions. As the postulators of the $\mathrm{I} 20$ acre theory are burdened with an arable of over $10,000,000$ acres in 1086 for some $1,800,000$ people, it easily follows that $20,000,000$ (on the same theory) would not be an excessive amount for $4,000,000$ folk temp. Ed. III. prior to I 348-9, and (still on that theory) some $30,000,000$ of arable, what time the Saxon estimate* of 242,700 Hides was made ; after this, it would be but little astonishing to hear that the whole country at one time consisted of a vast ploughed field, and that traces of terrace cultivation had been discovered on Scawfell Pike itself.

Ploughs Prof. Maitland has counted 70,606 ploughs Population in 30 of the recorded counties of D. B., which I086.

answers to an estimate of 84,130 for the 40 modern shires of England by as follows: 
$32,544,084$ total acres of which $3,759,67 \mathrm{I}$ in 5 counties (Cumberland, Durham, Monmouth, Northumberland, and Westmorland,) not in D. B., assuming Lancashire as returned; total recorded population 283,242 (Ellis), expanded to 300,000 for the missing shires, giving 5,586 ploughs for their supposed " recorded folk." Of the 4 counties Prof. Maitland does not give Yorkshire has some 2,959, Rutland 239 teams, and I have assumed 940 for Cheshire, and 3,800 for Suffolk, which with the 5,586 (above) and 70,606 adds to 84,130 . The population for Lincs, Norfolk, and Suffolk seems quite untrust- Fallacy of worthy (see note, p. I2), and to estimate the figures in number of oxen possessed by the average villein, counties. it is therefore necessary to omit them, and take statistics from the $3 \mathrm{r}$ remaining counties of D. B. : empirically divide the population into 4 classes, $A$, villans, sokemen, liberi homines, coliberts, and censarii; $B$, bordars, cottars, and coscez; $C$, Homines, radknights, Frenchmen, milites, thanes, and drenghs; $D$, the balance, including lords, mesne lords, burgesses, priests, swineherds, Welshmen, reeves, etc. ; and assume Class $A$ at 3 per plough, $B$ at $8, C$ at $\mathrm{r}, D$ at no teams save the demesne ones of mediate and immediate lords. This is of course incorrect, as many of the burgesses, priests, etc., had ploughs, but one assumption to a certain extent balances another, and the erudite supporters of the villeins should allow this mode of computation rather increases (unduly perhaps) their status: taking the recorded population of the 34 counties, Class $A$ consists of some 


\section{I23 Domesday and Feudal Statistics}

145,009 folk, $B$ of $89,443, C$ of 2,360 , and $D$ of the balance needful to total 283,242 ; as explained in the note on p. I 2, Lincs, Norfolk, and Suffolk would mar the calculation, (and unduly depreciate the villani), so it is necessary to subtract their totals, leaving 100,667 in Class $A, 69, I 82$ in $B$, 2,027 in $C$, and a total recorded number of 210,359 in these 31 counties.

The demesne ploughs are about $\frac{3}{10}$ of the total (see p. I 45), and as there are some 65, 179 teams in these counties, the lords thus have 19,554 , and the ploughs not in demesne would be 45,625 , i.e., 33,556 in Class $A, 8,648$ in $B$, and 2,027 in $C$, leaving a balance of $I, 393$ which would not cover the omissions, as for burgesses, etc. In other words, suppose $I, 000$ acres arable in aforesaid 3I counties, thus

Scheme of $r, 000$ acres arable I086.

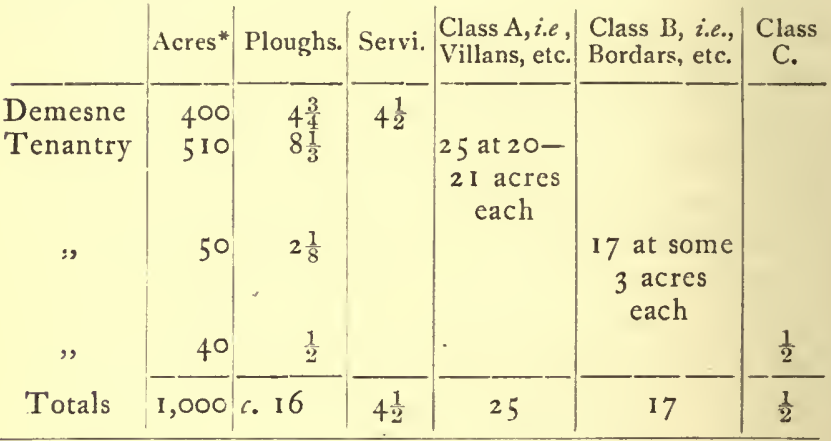

leaving 47 recorded folk as against i6 ploughs,

* For very precise information as to the modern statute acre, ride tables at end of Ctron. W. Thorn (St. Augustine's), where over 50 variations are given, all conforming to present measures; the above history terminates A.D. 1397. 
which is agreeable to the addition of Classes $A, B, C$, together with the 23,252 Servi (of 31 shires) ; viz., 195,128 for 65,179 teams, the remaining $15,23 I$ (of 210,359 total recorded) not being necessary to the example, but of course supported by above ploughs, and bringing up the number of people (as found) to the correct figure. This estimate presents the classes in due proportion to each other, and assumes each villan plough will average about half an acre per week, on the lord's land for 10 months, tilling some 1 5-16 acres p. a., as by Walter de Henley's scanty aration.

Prof. Maitland (p. 430 D. B. and Beyond) Norfoik seems to create and then admire at the difficulties not Teansof the Norfolk and Suffolk "Hidages," with little "Hides" success in solving them; he rightly observes " that ${ }_{\text {gheldum, }}^{a d}$ there are upon an average about 2 teams to every but mainly carucate is apparent on page after page of the areal record," and therefore concludes these carucates of arable are not teamlands, falling back on the supposition that they may be units of assessment. There should be little room to suppose they are either Hides or Teamlands (as Prof. Maitland understands a ploughland, i.e., I 20 acres), -to demonstrate the former the Hundred of Thingo is ample, occurring on fos. $286,289,349,356-8,381,391$, $40 \mathrm{r}, 425$, and 435 of D. B. ii., where the vills are assessed to gheld in no proportions whatsoever to the number of carucates they contain, as the following approximate list [given in the order in which the vills occur on p. 100, Feudal England (Round)] demonstrates: $7 \frac{1}{4}$ carucates, 7 d. ; I car. 6 d. ; $5 \frac{1}{4}$

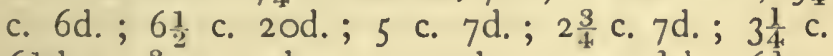

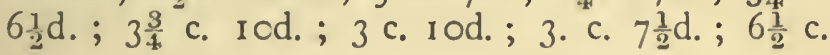




\section{25 Domesday and Feudal Statistics}

$6 \frac{1}{2}$ d. ; 4 c. 7 d. ; $2 \frac{1}{2}$ c. 7 d. ; $3 \frac{1}{2}$ c. 7 d. ; I c. 6 d. ; $6 \frac{1}{2}$ c. 20 d. ; $4 \frac{1}{4}$ c. I $3 \frac{1}{2}$ d. ; $4 \frac{1}{2}$ c. $6 \frac{1}{2}$ d. ; 6 c. 20 d. ; and 5 c. $60 d$. Prof. Maitland, with needless candour, states that to a knowledge of Agriculture, he does not attain-but founds his historic theories on conceptions (or rather misconceptions,) of that necessary Art, his admissions notwithstand-

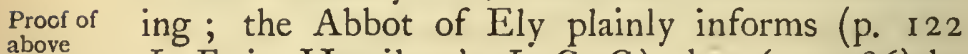
I. E. in Hamilton's $I$. C. C.) that (c. I086) he has $83(67+16)$ carucates of land plus 33 acres, land to $I 9 I$ ploughs, of which $122 \frac{1}{2}$ there, in Norfolk; and $I O 9(69+40)$ car. of land plus 42 $(32+10)$ acres in Suffolk, where land to 248 ploughs, and $219 \frac{1}{2}$ there, which is good evidence that the teamlands are better than twice the number of carucates. That these carucates are not the usual fiscal Hides has just been shown; besides the assessment to danegeld, etc., is given in quite an unusual form in these counties; as a rule the carucates of Norfolk and Suffolk seem to be the amount of land that might be under the plough, together with perhaps the appurtenances (several meadow and pasture), of a teamland, each carucate computed at $\mathbf{2} 20$ acres; the idea that this amount of land is the work of one plough is unknown to experience, and however practicable it may appear to any ex cathedrâ theorist, he is here confronted by the fact that such a calculation is refuted on "page after page " of his record, and by the singular appearance of the statistical consequences of such a surmise. If the carucates of the Ely Manors in either Norfolk or Suffolk are divided by the Teamlands, the quotient in both 
cases lies between 52 and 53 acres-a result which any agriculturist would allow to be reasonable; working from these figures, and estimating for the excess of population as recorded in these counties (vide note p. I 2), the difficulties named on p. 430 , $D$. B. and Beyond disappear, and the ratio of Teamlands to Population appears as it should : see also D. B. ii., I 69 , where the estate of I 8 sokemen (always 2 ploughs) is delivered for $a$ land; and ii., I 7 I, where I Manor delivered for 5 carucates seems to consist of 2 car. plus odd acres adding to 362 .

Passing to the evidence of Domesday Book and later records, in 1086 (D. B.) it sometimes happens that a rough approximation of the area of a Manor or district is given in leugæ, each of which have Lenge. been taken to represent I $\frac{1}{2}$ statute miles. Thus a Manor one leuga in length by as much in width (by this computation) would contain $I, 440$ modern acres; no exactness of dimensions can be expected, and of course the reality of rectangular blocks of lands is not postulated. Sometimes one imagines that greatest length and breadth is alluded to ; at other times an average, and in most cases the figures seem a rough estimate (the above remarks follow after testing Yorkshire examples by Jeffery's I 770 I" maps); now 3 of the Ripon " mile "Ripon " crosses (Sharow, Bishopton, and Littlethorpe) are "mile" about or within I,760 yards of the Minster (D. B., fo. $303 b$, about the church one leuga), and in the Manor of Hackness (D. B., fo. 323a), a modern mile would seem an excessive quantity. A very telling example is given on fo. $303 b$, as to the berewicks of Ripon (6 leugx in length by as many 


\section{Domesday and Feudal Statistics}

in breadth); here it may be stated with absolute certainty that the leuga was nothing approaching "Liberty I I $\frac{1}{2}$ miles; for the whole liberty of Ripon would of Ripon." not comprise 5 I,840 acres, and the portion of it included in the Domesday berewicks would well answer to a leuga of a modern mile or a trifle less; ${ }^{*}$ at the same time by taking the greatest length and the greatest breadth a leuga of $\mathrm{I} \frac{1}{2}$ miles would be found. An example like this on the large scale enables a statement of some certainty that here the leuga was either the modern mile, or else that (if I $\frac{1}{2}$ miles) the greatest and not average length and breadth was taken; and is of far greater worth than rash calculations from assumed perches of 18 to 20 feet, which by the way might reasonably be expected to be derived from the

* Ripon ana its Berewicks as given correspond to about How esti- half the Liberty of Ripon, the whole of which is considerably nated in less than the area comprised in 6 leuga long $\times 61$. broad, Domesday. taking $I$ leuga as $I \frac{1}{2}$ miles linear measure; by the area of the modern townships with additions the leuga works out just under I statute mile; a like explanation may then be reasonably postulated for such entrics as would give enormous ploughlands of up to 360 acres on a rectangular block calculation. For the berewicks of Ripon do extend 9 miles by 9 miles ( 6 lcuga $\times 61$.), but that is their greatest length and breadth, from which nothing can be asserted, and as demonstrated the actual area was but about ${ }_{5}^{2}$ of such as would be found by multiplying the greatest linear measures; in addition to this it may be held a ploughland contained in itself both pasture (not common of pa.) and meadow of the tenantry, at least for the plough oxen, of which numerous instances may be noted in the Yorkshire I. P. M.'s. (Yks. Record Serics), and the Hundred Rolls (vol. ii.); also sometimes houses were on the "ploughland." 
extremities of the "mesurabill" man (Ancient Scotch Laws), and therefore very well short of 12 inches. It may be noted that the marks (some yet in existence) representing the Banleuca of Ripon are locally known as mile crosses, nevertheless on what authority I know not, the Yorkshire Arch. and Top. Soc. have produced a modern ancient map of the county, with a scale rating the leuga at $1 \frac{1}{2}$ miles, which I venture to think will not be found applicable for areal measurement: however the following examples are wrought from Yorkshire that calculation, estimating a leuga in length by as Manors. much in width, as equivalent to a rectangular block of $I, 440$ acres. It will be observed that a piece of ground of the shape of a right-angled triangle by this computation would contain nothing unless 720 acres, and the nearer the approach to an $L$ shape, the lesser the extent; in many of the cases (below*) the impossible assumption that the whole Manor was under the plough has been made, for it is not always stated how much of its extent was in wood, meadow, and common of pasture ; where given, it is deducted from the total manorial area as shown. For example in Little Smeaton the Manor is given at I leuga long by $\frac{1}{2}$ as much wide, and unspecified underwood contained therein; this cannot be deducted and it is calculated as a rectangular block of land entirely tillage of 720 acres, and I 3 teamlands of 55 acres each, or less per actual plough (14 pls.). In the and entry (Berg, i.e., Barugh) no ploughs are 


\section{I29 Domesday and Feudal Statistics}

named by reason that the Manor was waste; omitting this the total amounts to less than 5, I I 5 acres, containing 103 teamlands and I 2 I $\frac{1}{2}$ ploughs, on an estimate from rectangular blocks raised from

Examples therefrom.

*AVERAGE PER TEAMLAND, io86 (D. B.), ASSUMI.NG THE SQUARE LEUGA EQUAL TO I,440 ACRES, AND RECTANGULAR AREAS.

\begin{tabular}{|c|c|c|c|c|c|c|}
\hline & Orig. fo. & $\begin{array}{c}\text { Extent } \\
\text { in } \\
\text { leuga. }\end{array}$ & Acres. & $\begin{array}{l}\text { Plough- } \\
\text { lands. }\end{array}$ & $\begin{array}{l}\text { Acres per } \\
\text { plough- } \\
\text { land. }\end{array}$ & No:es. \\
\hline Dewsbury & $29 g^{b}$ & $\frac{1}{3} \times \frac{1}{3}$ & 160 & 2 & 8o & 4 ploughs \\
\hline Barugh, etc. & $303 a$ & $\frac{1}{2} \times \frac{1}{4}$ & $180-7$ & 3 & 58 & $\begin{array}{l}7 \text { acres } \\
\text { meadow } \\
\text { plus un- } \\
\text { specified } \\
\text { waste. }\end{array}$ \\
\hline Welleton, etc. & $304^{b}$ & $I-\frac{5}{1} \frac{1}{2}$ & 840 & 20 & 42 & 2 I pls. there. \\
\hline Bulmer & $306 a$ & $\frac{1}{2}-\frac{7}{7} \frac{1}{2}$ & $580-20$ & 8 & $: 0$ & $\begin{array}{l}10 \text { pls. } \\
\text { meadow } \\
20 \text { acres. }\end{array}$ \\
\hline Farlington & $306 a$ & $\frac{1}{6}-\frac{1}{36}$ & $2 \mathrm{CO}-12$ & 4 & 47 & $\begin{array}{l}2 \text { pls.; mea- } \\
\text { d ow } 12 \\
\text { acres. }\end{array}$ \\
\hline Fleetham & $310 b$ & I $\times \frac{1}{2}$ & 720 & 15 & 48 & $9 \frac{1}{2}$ pls. \\
\hline Scruton & $310 b$ & $\frac{1}{2} \times \frac{1}{2}$ & 360 & 10 & 36 & 5 pis. \\
\hline Burton & $312 a$ & $\frac{1}{2} \times \frac{1}{2}$ & $350-(?)$ & 8 & $\begin{array}{c}\text { less than } \\
44 \frac{1}{2}\end{array}$ & $\begin{array}{l}\text { I4 pls.; un- } \\
\text { specified } \\
\text { under- } \\
\text { wood. }\end{array}$ \\
\hline $\begin{array}{l}\text { Sutton IIon- } \\
\text { grave }\end{array}$ & 3121 & $1 \frac{5}{2} \times \frac{1}{3}$ & 200 & 3 & 67 & 4 pls. \\
\hline $\begin{array}{l}\text { Middleton } \\
\text { Ouernhowe }\end{array}$ & $312 b$ & $\frac{5}{12} \times \frac{1}{4}$ & 150 & 3 & 50 & $3 p^{\prime \prime}=$. \\
\hline Foston & $313 n$ & $\mid \dot{4}-1^{1} \pi$ & 270 & 7 & $67 \frac{1}{2}$ & 6 pls. \\
\hline $\begin{array}{c}\text { Smeaton } \\
\text { Little }\end{array}$ & $316 a$ & $1 \times \frac{1}{2}$ & $720-(?)$ & 13 & 55 & $\begin{array}{l}\text { I4 pls. ; in- } \\
\text { specified } \\
\text { under- } \\
\text { wood. }\end{array}$ \\
\hline Tanshelf & 3161 & $\frac{3}{4}-\frac{1}{2}$ & $360-3$ & 9 & 40 & $\begin{array}{l}22 \text { pls. ; } 3 \\
\text { acres } \\
\text { meadow. }\end{array}$ \\
\hline Tadcaster & $321 b$ & ${ }^{5}: \frac{5}{12}$ & $250-16$ & 4 & 59 & $\begin{array}{l}7 \text { pls.; } 16 \\
\text { acres } \\
\text { meadow. }\end{array}$ \\
\hline
\end{tabular}


linear measurements of the leuga ( $\mathrm{I} \frac{1}{2}$ miles), which does not greatly flatter the I 20 acre theory. Again on fo. $165 a \mathrm{D}$. B. is a clear instance of a teamland of 64 acres; here is I Hide which when ploughed $\begin{gathered}\mathrm{r} \text { team to } \\ 6 \neq t \\ t\end{gathered}$ contains not unless than $\sigma_{4}$ acres, and there is one Domesday. plough; truly a small Hide (for their average areal scope is 300 acres and more), but nothing to show it is a small ploughland, as it is worked not by 2,4 , or 6 oxen, but by one plough.*

Very similar results follow from an examination of the lands held by the tenantry of the Bishop of Ely, for which reference should be made to the Inquisitio Eliensis as well as D. B.; thus under Ely
Manors. Cambridge to each plough of the tenants are in Wittleseia 32 acres, Doddintona 60, Litelport 35, Stoneteneia 30 , Stratham, 50, Wilbertona 52, Lyndona 80 or 58 , Heilla 40 , Wisbeach 56 , Ely $42 \frac{1}{2}$, Dunham 45, Winteworda 48 , Wickham 68 , Sutton 50, and Wicheforda 45, and in Herts, Haddam 28, Hatfield 58, and Chilleshelle 40, but here a difficulty arises, for the areas ascribed to the tenantry may be rather rateable than real, and also each villein plough will owe to till some of the land of the lord. Now certainly Seebohm,

* It is interesting to note how this passage has been twisted, for in the Rev. Bawdwen's translation he renders it that there are 64 acres when the land is not ploughed; the point seems to be that when you plough the land, you roughly know its mcasure; but perhaps the most singular misapprehension of any writer on D. B. occurs on p. 71 of Morgan's "England under the Normans," where, referring to $63 a$, ipse quoque transportavit ballam et alias domos et pecuniam in alio manerio the writer suggests this would not be difficult, as the buildings were constructed of wooden boards, etc. 
and more cautiously Prof. Maitland, accept such entries as areal extents, and thereby attach conMiddlesex siderable holdings to the villeinage of Middlesex
Villeins, and their holdings, 1086.

(the average villan here holds I virgate, cases of I villan with 2 Hides at Hanwell and W. Bedfont); now a test case can be found in the Manor of Heruluestune (Harlesden Green, fo. 1276 , and but once noted in D. B.), belonging to St. Paul's, where are 4 Teamlands, 2 ploughs in demesne, and $\frac{1}{2}$ plough held by 22 villeins, of whom 12 hold virgates and 1o half virgates. The total in villeinage (assuming each virgate $=30$ acres) amounts to 5 IO acres, against which set 4 oxen, or if the land were fully stocked 2 ploughs, and whether or not 510 acres could be tilled either by 4 oxen, or a couple of ploughs must be left to the sober judgment of any in the least acquainted with practical agriculture. To them it must be clear either that the acres here are rateable, or that they consisted largely of pasture (not improbable owing to proximity to London), or that the virgate in this Manor actually contained but a small number of acres.

Peterbo:o' Villeins, and their teams, I 125 -8.

Concerning the appended* tables, the virgate has been taken as 30 acres arable (save Alwoltuna, where 25 ac., see Rot. Hund., vol. ii., p. 638), though ancient evidences do not establish it to have been entirely in tillage; and it may be seen that in 1086 there were IO9 $\frac{1}{2}$ teamlands, $\mathrm{IO}_{4}$ teams, and 348 recorded folk, against I 39 teams and 434 pop. (recorded) in I I $25-8$, and at the

* See tables, pp. I 32, I 33, and note that Estona has I 2 fiscal carucates in 1086, and 3 hides ad in Waram, I 125 ; co. Leics. being rated both by Hides and Carucates: see note, p. 39. 
latter date the ploughs of the sokemen have been added in brackets - the average acres per villein plough (including work on demesne) being 64 .

Now it would seem to be an extremely obvious rule that as folk increase more food is required, Population and consequently more land tilled and ploughs $\begin{gathered}\text { varies as } \\ \text { Ploughs. }\end{gathered}$ used, but this simple fact would appear to have escaped the attention of philosophers: an argument based on the theory that because in certain Manors in 1222 a mixture of tenants holding by rent and villein services cultivate $\mathrm{X}$ acres, the: predecessors in 1086 also arated the said $\mathrm{X}$ acres, and that therefore the acreage per plough in 1086 may be discovered by dividing the X acres of 1222

*1125-28, LIBER NIGER DE MON. SANCT. PETRI DE BURGO.

\begin{tabular}{|c|c|c|c|c|c|c|c|c|c|c|}
\hline & $\frac{\grave{\Xi}}{\dot{\Xi}}$ & $\frac{\dot{\leftrightarrows}}{3}$ & 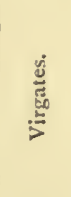 & 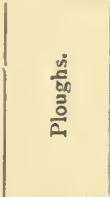 & $\frac{\dot{v}}{\tilde{y}}$ & 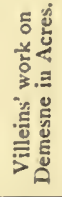 & 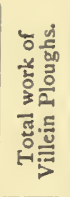 & 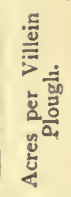 & 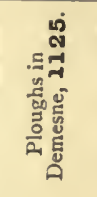 & 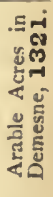 \\
\hline Kettering ... & N'ants & to & 40 & 22 & $x, 200$ & 314 & I, 434 & 65 & & 300 \\
\hline Tinguell ... & " & 33 & $2 \div \frac{1}{2}$ & 12 & 795 & 34 & 820 & 68 & 2 & Iro \\
\hline Oundle & $"$ & 25 & 20 & 9 & 600 & $1+4$ & 708 & 78 & & 205 \\
\hline Pilesgete & & 8 & 5 & 2 & 150 & 16 & 162 & 81 & $I+(8)$ & \\
\hline Colingham & Notts & $20+50$ & $6+10$ & $x_{4}$ & 480 & 90 & $54^{8}$ & 39 & 2 & 208 \\
\hline Cotingham & N'ants & 17 & 15 & 6 & $45^{\circ}$ & +5 & 484 & 80 & 2 & 153 \\
\hline$\ldots$ & Leics & $2 I$ & $2 \mathrm{I}$ & 12 & 630 & 50 & 667 & 55 & & 102 \\
\hline Wermintona & N'ants & 49 & $3+\frac{1}{2}$ & 16 & $x, 035$ & 117 & $x, 123$ & 70 & $4+(6)$ & 210 \\
\hline Turlebi ... & Lincs & 8 & 4 & 2 at least & 120 & 12 & 129 & 65 & I & 55 ? \\
\hline Alwoltuna & Hunts & 29 & 18 & 7 & $45^{\circ}$ & 9 & 459 & $6 \overline{6}$ & 2 & \\
\hline Totals ... & & & & 102 & 5.910 & & 6,524 & $\begin{array}{c}64 \\
\text { aver- } \\
\text { age. }\end{array}$ & $23+\left(I_{4}\right)$ & \\
\hline
\end{tabular}

N.B. - The 6.524 acres is obtained by adding 3 of the work on demesne to the tenants" acres, as the demesne is counted as but one ploughing-according to Sir Walter de Henley, in a 3 -course shift each acre had $\frac{1}{3}$ ploughings: the demesne arable of 1321 , is of course but an indication of same in 1125 , liable to increase or dininution-in 1321 are 460 ac. ar. at le Bigginge under Oundle, 260 being frisca. 


\section{33 Domesday and Feudal Statistics}

* DOMESDAY, I086, CONTRASTED WITH L.N.P.

\begin{tabular}{|c|c|c|c|c|c|c|c|c|c|c|c|}
\hline & & & & & & & & & DETA & AILS & of Population. \\
\hline & Place. & & 总 & 莺 & $\stackrel{\dot{n}}{b c}$ & 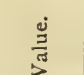 & 咅 & ह่ & ت. & $\ddot{-}$ & \\
\hline $\begin{array}{l}\text { Collation } \\
\text { of some } \\
\text { Peterboro' }\end{array}$ & $\begin{array}{c}\text { Kettering } \\
\text { \# }\end{array}$ & $\begin{array}{l}1086 \\
125\end{array}$ & $\begin{array}{l}\text { 10 } \\
\text { 10 }\end{array}$ & 16 & $\begin{array}{l}1+10 \\
4+22\end{array}$ & $\begin{array}{l}\text { II li. } \\
26 \mathrm{li} .\end{array}$ & $\begin{array}{l}34 \\
52\end{array}$ & $\begin{array}{l}3 r \\
40\end{array}$ & $\overline{8}$ & $=$ & $\begin{array}{l}\text { I ancilla, } 2 \text { mills } \\
2 \text { herds, I freeman, } \\
\text { I miller }\end{array}$ \\
\hline $\begin{array}{l}\text { Mlanors, } \\
\text { I } 25^{-8} \\
\text { with }\end{array}$ & $\begin{array}{c}\text { Tingwell } \\
\text { ", }\end{array}$ & $\begin{array}{r}086 \\
\mathbf{1} 25 \\
\end{array}$ & $\begin{array}{r}5 \frac{1}{3} \\
4 \frac{1}{2} \\
\end{array}$ & 8 & $\begin{array}{r}2+7 \\
2+\mathrm{r} 2 \\
\end{array}$ & $\begin{array}{r}7 \mathrm{li} . \\
15 \mathrm{li} . \\
\end{array}$ & $\begin{array}{l}37 \\
43 \\
\end{array}$ & $\begin{array}{l}24 \\
33 \\
\end{array}$ & $\begin{array}{r}11 \\
4 \\
\end{array}$ & $\bar{z}$ & $\begin{array}{l}2 \text { mills } \\
4 \mathrm{~h}+\mathrm{rds}, 2 \text { millers }\end{array}$ \\
\hline Domesday. & Oundle & $\begin{array}{l}1086 \\
x \times 25 \\
\end{array}$ & $\begin{array}{l}6 \\
4\end{array}$ & $\underline{9}$ & $\begin{array}{l}3+9 \\
3+9\end{array}$ & $\begin{array}{l}\text { ax li. } \\
\text { II li. }\end{array}$ & $\begin{array}{l}37 \\
43\end{array}$ & $\begin{array}{l}23 \\
25\end{array}$ & $\begin{array}{l}\text { To } \\
\text { ro }\end{array}$ & $\underline{3}$ & $\begin{array}{l}\text { I mill } \\
2 \text { freemen, } 6 \text { herds }\end{array}$ \\
\hline & $\begin{array}{c}\text { Pilesgete } \\
\text { ", }\end{array}$ & $\begin{array}{l}1086 \\
1125\end{array}$ & $\begin{array}{l}6 \\
3\end{array}$ & 6 & $\begin{array}{c}x+1 r \\
x+(8)+2\end{array}$ & $\begin{array}{rl}4 & \mathrm{li} . \\
& \\
4 & \mathrm{li} .\end{array}$ & $\begin{array}{l}39 \\
57\end{array}$ & $\begin{array}{l}9 \\
8\end{array}$ & 2 & 1 & $\begin{array}{l}26 \text { sokemen, } 1 \text { mill } \\
44 \text { sokemen, } 2 \text { herds, } \\
x \text { mill }\end{array}$ \\
\hline - & Cotingham & $\begin{array}{l}x 086 \\
1125 \\
\end{array}$ & $\begin{array}{l}7 \\
5\} \\
\end{array}$ & $\underline{14}$ & $\begin{array}{l}2+10 \\
2+6\end{array}$ & $\begin{array}{rl}3 & \mathrm{li} . \\
12 & \mathrm{li} . \\
\end{array}$ & $\begin{array}{l}44 \\
30\end{array}$ & $\begin{array}{l}29 \\
17 \\
\end{array}$ & $\begin{array}{r}\text { 10 } \\
7 \\
\end{array}$ & 4 & $\begin{array}{l}\text { I mill } \\
\text { I mill, } 5 \text { freemen }\end{array}$ \\
\hline & $\begin{array}{c}\text { Estona } \\
",\end{array}$ & $\begin{array}{l}1086 \\
1125\end{array}$ & $\begin{array}{c}x 2 c . \\
3\end{array}$ & 16 & $\begin{array}{l}2+8 \\
2+12\end{array}$ & $\begin{array}{l}5 \mathrm{li} . \\
12 \mathrm{li} .\end{array}$ & $\begin{array}{l}27 \\
34\end{array}$ & $\begin{array}{l}\text { 10 } \\
21\end{array}$ & 5 & - & $\begin{array}{l}12 \text { sokemen } \\
\text { I homo, } 2 \text { mills, II } \\
\text { sokemen }\end{array}$ \\
\hline & $\begin{array}{c}\text { Wermintona } \\
,\end{array}$ & $\begin{array}{r}1086 \\
1125\end{array}$ & $7^{\frac{1}{3}}$ & x6 & $\begin{array}{c}4+8 \\
4+(6)+16\end{array}$ & $\begin{array}{l}\text { x li. } \\
\text { so li.t }\end{array}$ & $\begin{array}{l}36 \\
60\end{array}$ & $\begin{array}{l}32 \\
49\end{array}$ & - & 3 & $\begin{array}{l}\text { I mill } \\
\text { x mill, \& sokemen, } \\
\text { I clk, I freeman }\end{array}$ \\
\hline & $\begin{array}{c}\text { Alwoltuna } \\
, ", \\
\end{array}$ & $\begin{array}{l}1086 \\
1125 \\
\end{array}$ & $\begin{array}{l}5 \\
5 \\
\end{array}$ & 9 & $\begin{array}{l}2+7 \\
2+7 \\
\end{array}$ & $\begin{array}{l}7 \mathrm{li} . \\
4 \mathrm{li}+\end{array}$ & $\begin{array}{l}22 \\
36 \\
\end{array}$ & $\begin{array}{l}20 \\
29 \\
\end{array}$ & $\overline{6}$ & 二 & $\begin{array}{l}2 \text { mills } \\
1 \text { renter }\end{array}$ \\
\hline & $\begin{array}{c}\text { Colingham } \\
\text { ", }\end{array}$ & $\begin{array}{l}1086 \\
1125\end{array}$ & $\begin{array}{l}4 \frac{3}{10} \\
4 \frac{1}{1} \frac{1}{10} \\
\end{array}$ & 14 & $\begin{array}{l}2+14 \\
2+14\end{array}$ & $\begin{array}{l}9 \mathrm{li} . \\
20 \mathrm{li} .\end{array}$ & $\begin{array}{l}67 \\
70\end{array}$ & $\begin{array}{r}8 \\
20\end{array}$ & $\frac{20}{-}$ & $\bar{z}$ & $\begin{array}{l}37 \text { sokemen, } 2 \text { mills } \\
\text { 50 sokemen }\end{array}$ \\
\hline & $\begin{array}{c}\text { Turlebi } \\
\text { ", }\end{array}$ & $\begin{array}{l}1086 \\
1125\end{array}$ & $\begin{array}{l}1 \frac{1}{2} \\
1 \frac{3}{5}\end{array}$ & $-1 \frac{1}{2}$ & $\begin{array}{l}x \\
x+2\end{array}$ & $\begin{array}{ll}1 & \text { li. } \\
3 & \text { li. }\end{array}$ & $\begin{array}{l}5 \\
9\end{array}$ & $\begin{array}{l}I \\
8\end{array}$ & 4 & $\overline{-1}$ & I priest \\
\hline
\end{tabular}

by the ploughs in Domesday may at first sight

Eccentric views of plilosophers. appear plausible, but if one finds the recorded population in $1086 \mathrm{Y}$ and in $12222 \mathrm{Y}$, or $2 \mathrm{Y}$ plus, one can be of no other opinion than that their ingenious author has not mastered the above plain idea as to increase of population, etc. Such an illustration is set forth in a table on p. 288 , English Historical Review, I 897 (composed by 
F. Baring), and the patient reader is gravely informed "he can thus arrive at the exact acreage of holdings 1086," that is, like a modern Charon, by transfretting the villans and their ploughs of 1086 on to the acres (by no means all in villeinage) of I 222. Just to exhibit this happy method of enlivening the "bald details" of Domesday, take the cases of Runewell and Cadendone (Domesday St. Paul's, I 222), as cited by our author on p. 288 (E. H. R., I 897 ); one is told of 240 acres in 1222 (best part of them set to a rent by the way) described as 8 tenants' virgates, and of 8 villans and 8 bordars with $2 \frac{1}{2}$ ploughs here (Runewell) 1086, and invited to believe that therefore the D. B. villans each had 30 acres, working 120 acres per plough. On referring to the Camden Society's vol. (D. B., ExaminaSt. Paul's) the jurors of Runewell state the Hide their was formerly computed at 80 acres, but now (I222) it is 120 , and that on account of the poverty of some of the villein tenants their holdings had been taken into the demesne; on adding up the occupants of the Manor I222 one finds 34-38 tenants (not eight as our author suggests, supported by nothing unless his endeavour to tie a virgate to each D. B. villan at all hazards) against 16 in 1086 . Turning to Cadendon, by some process of adding up divers sorts of holdings in 1222 what are styled $24 \frac{1}{2}$ " tenants virgates " of 28 acres each $(686 \mathrm{ac}$.) are discovered for $22 \mathrm{D}$. B. villans ( I086)* who had 6 ploughs, hence I I 2 acres

* The writer seems to have been unaware there is further notice of this Manor of St. Paul's on fo. $211 a$, hence his 


\section{Domesday and Feudal Statistics}

per team ; but referring to the records the population noted in 1086 is 29 against over 100 (not $\left.24 \frac{1}{2}\right)$, of which some are probably named twice over, so that one certainly cannot credit that where the population had doubled (and more) in 1 222, there had been no increase of ploughs over the number given in Domesday.

After such glaring examples of our author's manipulations, it must be left to the judgment of the candid reader whether or not this mode of Utility of work is an abuse or use of Records, but if instructhe philosophic treatment. tive comparisons are to be made, it is important that none of the essential particulars be omitted. From the following the reader may form his own inferences, and by referring to the originals make any additions of matter bearing on the point ; not wishing, however, to emulate the pea and thimble tactics of a certain school, nothing has been

X suppressed in the first instance, with a view to prejudice the case.

Manor of

The Manor of Alwalton is illustrated 1086 Alwalton, and $r_{3}$ th centuries.

(D. B.), I I 25-8 (L. N. P., Camden Soc.) and I $278-9$ (Rot. Hund., vol. ii.); by turning to the tables above, ${ }^{*}$ it may be seen that in 1086 are recorded 9 teamlands, 9 ploughs ( 7 in villeinage) and 22 folk (bordars and servi perhaps omitted); in II 25-8, 9 ploughs and 36 people, and in I 278-9 (H. R. no ploughs given) are $5 \frac{1}{2}$ Hides and $I_{2} \frac{1}{2}$ Virgates of land, the virgate 25 acres, at 5 to the Hide; of which the details account for

$x$ figures are incomplete-nevertheless are used here as they serve well enough to illustrate his statistical methods.

* See pp. 132, r 33 . 
726 acres, i.e., $5 \frac{1}{2}$ Hides, $1 \frac{1}{2}$ Virgates plus one acre, as under :

200 acres arable in demesne

$45^{\circ}$ " land by 18 villans of 25 acres each

$62 \frac{1}{2} ", "$ " 5 " $12 \frac{1}{2}, "$

$\frac{13 \frac{1}{2}}{726}$ acres

In addition 2 free tenants hold $28 \frac{1}{2}$ acres, and belonging to the demesne $\frac{1}{2}$ acre of court and garden, I ac. of several pasture with 8 of meadow, and of course (tho' unnamed) presumably some considerable amount of common of pasture, and wood, which if extra manorial the tenants had access to ; the writer is of opinion that several pasture and meadow is included in the villein holdings (the plough oxen would require hay), but has made no deduction on that ground. There are 59 tenants, but 4 are $2-$ named, and 5 widows in cottages, and as the extent seems a full one, I do not think the record population should be put higher than 50 ; the I 8 virgates ( 450 ac.) seem to appear as the same amount in I I 25-8, held then by 7 full and 22 semi-villani, and the $62 \frac{1}{2}$ acres of $1278-9$ might well have been assarted for the support of increasing population since I I $25-8$, in which there is no mention of them. But I cannot find that one has right in saying that the 756 acres (keeping some 50 recorded folk) in $1278-9$ were in cultivation therefore in I I 25-8, (keeping 36 people), and that therefore 9 ploughs worked 746 acres then and in 1086 ; even if after the most ingenuous manner of the English Historical 


\section{I37 Domesday and Feudal Statistics}

Review, you suppose population may increase or double without a corresponding cultivation, the calculation would work out at nothing unless 83 acres per team.

Attention is also called to the following interesting references from D. B. and the Hundred Rolls (Vol. 2, well indexed):

\section{HISTON.}

Manor of Histon I086, and 1278 .

D.B. Cambridgeshire; Lands of Bp. Lincoln, fo. 190 a and $b$. Hides. Teamlands. Teams. Villans. Bord. Cott. Servi. Total $8+83-3+10 \quad 2+9018$ \begin{tabular}{llllllll}
$\frac{93}{26 \frac{3}{2}}$ & $\frac{2+4}{5+14}$ & $\frac{1+2}{3+11}$ & $\frac{10}{28}$ & $\frac{19}{37}$ & - & $\frac{4}{4}$ & $\frac{29}{4}$ \\
\hline
\end{tabular} 1279. Hundred.Rolls. Vol. II. (pp. 4 I I-I 3); rough Summary.

The Abbot of Eynsham holds $15 \frac{1}{2}$ Hides of the Bp. of London.

Demesne 7 acres arable, 10 ac. mea. Liberi $\quad 46 \frac{1}{2}$ ac. by 7 men $\quad \ldots \quad$... $74 \quad 46 \frac{1}{2}$

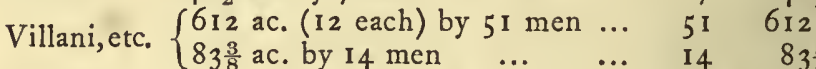
Crofters no land named

Philip de Coleville holds I I Hides of the Bp. of Lincoln.

Demesne Liberi

Villani Cottars 20 ac. by 28 men
* Military tenant subinfeuded 300 " 30 " (10
Pop.

I Hide ro ac. mea. 69 ac. by 10 men ... 10 each) $\quad \ldots \quad \ldots \quad 30$ 20 ac. by 28 men $\ldots . \quad 28$ 20
I Hide 10 acres.

$69 "$ 300, 20 is I $60 \frac{1}{4} "$,

* Items of this holding on P. 138 . 


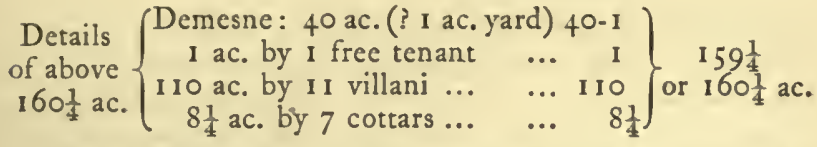

The Hidage at both periods totals $26 \frac{1}{2}$, but whereas 73 folk are on record I086; I95 are noted in 1278 , and the Inquisition then finds by detail I Hide and I.5 I 3 ac. of land, - so that there is presumably a balance of land in common of pasture, waste, etc., which inference the D. B. entry (fo. I 90a) seems to confirm, for in demesne there were 2 Teams, 3 Teamlands, and 8 Hides; supposing the Hide (not recorded in acres) in 1278 contained I 20 acres, then would there have been I 633 (less, as some described as meadow) acres arable, and yet in 1086, with less than. half the recorded population, there were 19 Teamlands and I4 Teams.

The Hundred Rolls often set forth the total Hundred Hides* and proceed to give them in detail approximately agreeing at the rate of I 20 acres per Hide (or some other stated no. of acres), but in the above the fiscal Hidage of D. B. is given as a heading ; and lest the view that such Hides might be answered from land not all arable be thought fanciful, I append the following $†$ :

* In some cases, however, the Hides of the Hundred Rolls do not seem to correspond with the cultivated area of the Manors described.

$\dagger$ Assumptions that the fiscal Hide is of necessity rated on arable alone, merely discovers their authors' lack of acquaintance with Domesday, and that such are of a certain class or historic writers, the brightness of whose genius enables them to expound that record without having read it; but though 


\section{39 Domesday and Feudal Statistics}

Manor of

Coatham, I086, and 1297.
D. B. 1086. Cambridgeshire, Coatham, Abbot Croyland (fo. 192a); $6+5$ Hides ; $2+6$ Teamlands; I +6 Teams; I 2 Villans, 8 Bordars, I Servus, that is 2 I recorded folk, also meadow to 8 plough teams, and pasture for the vill stock, and a marsh rated at 500 eels.

Here again are 6 Hides set against 2 demesne teamlands giving rise to suspicion that the marsh

Genius of our fountains of learning inspire their votaries with somethe

Romantic School. thing of the "divine afflatus," those subtle qualifications may, by the simple, easily be mistaken, for the mere manipulations of the prestidigitateur; and at any rate the dull path of History is too confined a sphere for talents so impatient of necessary bounds and limits, and better adapted to the more sympathetic regions of Romance, for which their alma mater has so adequately equipped them. There are of course genuine students of History, even within the precincts of learning, and one in especial, who has shed a particular lustre on a School which stood greatly in need of it, of whom every Yorkshire and English scholar may well be proud, and whose works may justly rank with those of Brady, Dodsworth, Dugdale, Madox, and Rymer. By way of illustraFiscal tion of Hides other than arable in D. B.; for rvood sce $180 b$, Hides do 205a, 21 2a, 216a, 228a, and 244a; for castles, 62b, 248b;

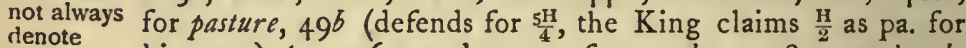
Arable land. his oxen), 65a, 96a, and 104a; for gardens, 298a; as in the forest, $32 a$, and $263 b$; as in meadow, $7 a$ ( 1 jugum at farm, nothing there but 2 ac. mea., worth IOs.), 286 ( $\frac{\mathrm{H}}{2}$ and scots for it, but only 10 ac. mea. worth 5 s.); and $377 b$ (Warnode of Io ac. mea.); as between wood and plain, $164 a$ and $175^{b}$ (numbered for $15 \mathrm{H}$. between wood and plain); the County of Yorks generally, where the areas and values of whole Manors, and the woods in them, are often separately computed, the latter as part of the former; also see the I.P.M. of Elizabeth Moubrai, where the Manor of Kirkby Malesart contains no arable land, but 2 carucates, the herbage of which, etc., $38 \mathrm{Ed}$. III. 


\section{Agricultural Statistics}

was both rateably and really within the Hide, Marsh which inference is established beyond any reasonable doubt as in 1279 (p. 409, vol. ii., H. R.) " they say that the abbot and convent of Croyland hold and defend in the vill of Coteham in Hides as in lands, meadows, pastures, and marshes," and "they hold in demesne of the said I I Hides, 2 Hides arable, and 5 Hides in meadows, pastures, and marshes* pertaining to the said vill," and in tenants $3 \frac{1}{2}$ Hides arable.

Now $\frac{1}{2}$ Hide is unaccounted for, and it may be that the tenants held it as in meadow, pasture, and marsh, or rated against a couple of windmills : of the $3 \frac{1}{2}$ Hides arable, 9 free tenants hold 59 acres plus (the 2 nd best by rent being undescribed as to acres), 44 villeins have 335 acres, and 5 men pay house rent, so possibly the omitted acreage was 26 , the amount necessary to bring up the total to 420 acres ( $3 \frac{1}{2}$ normal Hides). If the $5 \frac{1}{2}$ Hides of arable are taken at 660 acres, it may be observed there were 8 Teamlands and 7 Ploughs in 1086 with a recorded population of $2 \mathrm{I}$, which now

* In 1086, arable land was perhaps worth 2 d. (Id. to 3 d.) Values of per acre; see D. B., $165 a(64$ ac. ar. worth 16 s., formerly Arable, 20s.); 1976 (10 ac. land, 8d.), ii. 3, I1 8, 260, and 341 ; also ii. 275 ( 120 ac. land, and 5 ac. mea. worth 30 s.) ; ii. $9+$ $(80$ ac. ar. and 200 ac. marsh worth 20s.); as to meadow, $7 a$ ( 2 ac. worth 1os.) ; $28 b$ (10 ac., 5s.), and sec note, p. 139; wood, 228a, worth IOs.; 244a, worth 3li. Perhaps land, as per team would be worth 16s. (or less), if, the Northern counties were included, but not more than Ios. of this should be set against each plough ( 8 oxen), leaving the balance against meadow, pasture, woods, and other sources of profit, as jurisdictions, mills, fisheries, etc. 


\section{I4I Domesday and Feudal Statistics}

(1 278-9) has increased to 58 : according to the statistics from D. B. (Ploughs to Recorded Pop.) there would be 16 Teams in the Manor at the later date.

Now these are not isolated instances, as the folOther lowing if worked out would show: Wodestone, co. Manorial Hunts, Abbot of Thorney; Fletton, co. Hunts, Abbot of Peterboro'; Newton, co. Hunts, Abbot of Thorney; Drayton, St. Paul's, Middlesex ; referring to D. B. and the Rot. Hund, and in the last case to St. Paul's Domesday (Camden Soc.).*

It often occurs that the Hundred Rolls estimate the arable demesne in carucates (as where it was out of the Hide), and this may be 120 acres; indeed Seebohm has given an instance of one of 200 acres, (Eng. Vill. Comm.) but on turning to the record (p. 328 H. R.) it runs "I carucate of land which contains ro score acres of land, meadow, and pasture," and I believe the following are all the entries in co. Beds.

160 acres. 120 ac. 100 ac. 80 ac. 60 ac. Total Average. $\frac{1}{2}$ car. $5 \frac{1}{4}$ c. 6 c. 8 c. 5 c. 25 car. $\} 91 \frac{1}{0}$ acres Bedford- 80 ac. 660 ac. 600 ac. 640 ac. 300 ac. 2280 ac. $\int$ per carucate. shire Carucates. Thus it will be seen the carucate was a variable quantity, hitherto ingeniously explained by the

* The Hundred Rolls are useful for 5 counties only, and of these Church Lands are most suitable for comparison, owing to the great changes in ownership and partition of lands since 1086 , in addition summing up the items in 1 278-9 is a troublesome process, and likely to be interrupted by gaps : it is of course open for any one to demonstrate the I 20 acre theory by the same method, if they have luck enough to find the least confirmation of it by a just comparison. 
relative lightness or heaviness of the soil ; this I believe has little to do with the matter, as fewer or more oxen and horses would be used, instances of which can be seen generally in the fields nowadays, and occur so numerously in custumals, etc., as to need no specification. In a certain sense the ploughland was $\mathrm{I} 20$ acres, that is examples are taken from the demesne not from the land in villeinage, and as the Bedford table shows the greatest no. of acres hit that amount (660 acres in I 20 acre lots), but this is nothing to the point, for the variability of the carucate alone should indicate its meaning (missed by at least every modern writer), i.e., that these demesne ploughlands were such varying amount of land as one plough of the lord tilled with the assistance of his tenants; for proof of which the following may be taken, all Proof that from the Ramsey Cartulary (Rolls Series), I 25 I demesne contrasted with Rot. Hund. 1 279, and other were not records, being the only* returns which I have been One Team. able to discover, where the aid of the villein teams is estimated in ploughs per annum, and all here set down :

Inquisitions 1251-2 Ramsey Cartulary.

Demesne. Assistance.

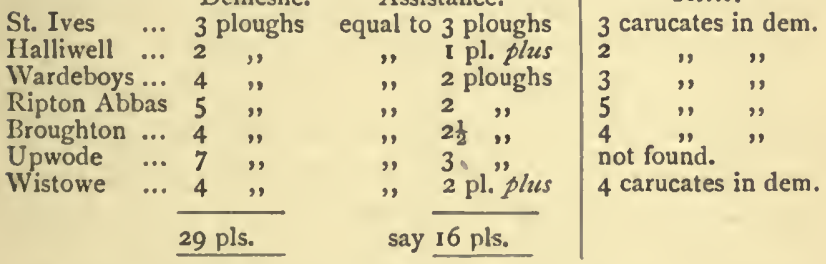

I 279 Hundred Rolls. 


\section{43 Domesday and Feudal Statistics}

Ramsey Except Upwode all these places may be found in Manors. the Hundred Rolls under Hunts, and in all of the 6 cases there is complete agreement, save in Wardeboys, where there were 4 demesne ploughs in $125 \mathrm{I}$ against 3 carucates in 1279: the total assistance to 29 demesne ploughs in seven Manors is I 6 ploughs (as by villeins), the $\frac{1}{2}$ plough being made up of two cases of et amplius; now the average demesne carucate in Beds has been shown to be $9 \mathrm{I} \frac{1}{5}$ acres, which as above would leave about 60 for the plough of the lord, and the rest $\left(31 \frac{1}{5}\right)$ for that of the tenant. On p. 629 (Rot. Hund., vol. ii.) under Westone the Abbot (Ramsey) holds Assistance in demesne 8 carucates of land together with the from astoughs asistance of his customary tenants which said of the Customary demesne contains 548 acres, which can mean nothing unless that his own ploughs together with the assistance of his tenants equal 8 ploughs and suffice for 548 acres, or else that there were in demesne 8 ploughs in addition to assistance from the villeinage. The Manor of Weston (as cited above I 279) contained the hamlets of Brington and Bitherne in which were 4 demesne teans 1086 (D. B.), and as many as 7 temp. Hen. I. (Ramsey Cart.) and unfortunately there are no further records of the ploughs there till $\mathrm{I} 279$.

Of the 7 Hunts Manors in the table, all (save Broughton perhaps) were out of Hide in 1086, at St. Ives, 3 demesne ploughs, 1086, at Haliwell 2, and 2 temp. Hen. II., at Warboys 3 and 3 temp. Hen. II., at Ripton Abbas 2, at Upwode 2 and 4 temp. Hen. II., at Broughton 4 and 4 temp. Hen. II. and at Wistorwe 2, and 3 temp. Hen. II. In 1232 (ex Rot. Mai. Archiep. Gray. In dorso 
No. 64) the Archbishop of York leased to the Lease of Prior and Convent of Hexham the demesnes there Hexham for a term of 15 years, to be returned in the same ${ }^{\text {r232. }}$ condition as received as to crops and fallow; the total being $179 \frac{1}{2}$ acres of arable land in 9 fields or portions of fields (all specified), of which 78 acres in Oats, $51 \frac{1}{2}$ in Wheat, and 50 in bare fallow (terra warrecanda), together with the precations of ploughs and harrows of the tenantry, and with pasture for 16 oxen, and ploughbote for the draught of 2 ploughs-so that here were 90 acres per demesne plough, part of which 90 acres the villeinage would cultivate.

Again in 1292 (Malmesbury Reg. Rolls Series) Lease of le a lease was made by the Abbot to the cook ${ }_{\text {rag2. }}^{\text {Blake }}$ $20 \mathrm{Ed}$. I. April of le Blakelound consisting of I05 acres sown (fallow not named) to wit 62 of wheat, II barley, beans, and vetches, and 32 of oats, together with ros. of pasture, IOs. of customary works, 16 oxen, 2 horses, ploughs (caruc'), and 2 harrows, etc.*

Further, in 47 Hen. III. (I.P.M. Yorks Record Series), in the I.P.M. of Baldwin de Insula, there are at his Manor of Harewood 279 acres arable in Manor of demesne worked by 3 teams, nevertheless imme- ${ }_{47 \text { Hen.III. }}$. diately follow the plough services of the tenantry on those acres equal at least to tilling I 30 of them once over, so that tho' he may have 3 ploughlands of 93 acres each, and 3 ploughs in demesne, this is nothing to the purpose in the matter of actual work of one plough. Also in the same vols.

* The deed cited in the Malmesbury Reg. just before this one makes clear that caruc' means ploughs here-and not a plough-presumably two. 


\section{45 Domesday and Feudal Statistics}

in another inquisition 'tis noted that each sokeman must bring to the work of the lord at the rate of one plough for every 4 bovates held in socage. Not that a carucate of land in demesne always means the amount of land which corresponds to the number of ploughs the lord holds, for in the Reg. Roff. on cross-examination the bailiffs of the Manors state the number of dominical teams, and Rochester also that they have not as many carucates of land, Carucales. because there are not in those Manors the number of acres which by custom of the district would make corresponding carucates, and further it must be remembered that this word is sometimes used for fiscal (not areal) units, as in the carucated counties in Domesday, and in Kirkby's Quest, the Books of Knights' Fees, and of Aids for Yorkshire, also sometimes in I.P.M.s.

A.D. I086, NINE COUNTIES TABLE FROM D. B.

Proportion of teams in demesne, ro86.

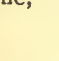

Bucks

Dorset

Glos'ter(T.)

Herts

Kent

- Middlesex

Oxon

Rutland ...

Yorks

\begin{tabular}{|l|} 
Teams. \\
\hline $2056 \frac{3}{4}$ \\
1826 \\
3909 \\
$1369 \frac{1}{2}$ \\
$3141 \frac{3}{8}$ \\
546 \\
2461 \\
$238 \frac{5}{8}$ \\
$2958 \frac{7}{8}$
\end{tabular}

\begin{tabular}{|c|c|c|c} 
Lords'. & Tenants'. & $\begin{array}{c}\text { Percentage } \\
\text { of latter. }\end{array}$ & $\begin{array}{c}\text { Villeins, * etc } \\
\text { per Plough. }\end{array}$ \\
\cline { 1 - 2 } $689 \frac{1}{4}$ & $1367 \frac{1}{2}$ & $66 \frac{1}{2}$ & $2 \cdot 1$ \\
$752 \frac{1}{2}$ & $1073 \frac{1}{2}$ & $58 \frac{3}{4}$ & $2 \cdot 5$ \\
$1058 \frac{1}{2}$ & $2850 \frac{1}{2}$ & 72 & $1 \cdot 37$ \\
475 & $894 \frac{1}{2}$ & 65 & $2 \cdot 0$ \\
$697 \frac{3}{4}$ & $2443 \frac{5}{8}$ & $77 \frac{3}{4}$ & $2 \cdot 7$ \\
152 & 394 & 72 & $3 \cdot 0$ \\
$818 \frac{1}{2}$ & $1642 \frac{1}{2}$ & $66 \frac{3}{4}$ & $2 \cdot 2$ \\
$43 \frac{5}{8}$ & 195 & 82 & $3 \cdot 75$ \\
$782 \frac{3}{8}$ & $2176 \frac{1}{2}$ & $73 \frac{1}{2}$ & $2 \cdot 33$
\end{tabular}

* The result arrived at by dividing the number of villeins in the county by the tenants' ploughs, as the latter are owned by as well villani as others, the quotients of course are usually far too low. 
Seebohm appears to have made a nice approximation to cultivated England in 1086 at 5 million acres for the recorded counties, which if I understand the Village Community rightly is as under :

108,407 villans with

23,000 sokemen with

I 2,000 liberi homines with

In demesne

89,000 bordars and cottars
2,250,000 acres and ploughs. $500,000, "$,

$500,000 ", \quad "$,

1,500,000 ", ,"

250,000 , and no ploughs.
Estimate of England, 1086, in the Village Community.

5,000,000 acres.

counting $\frac{1}{2}$ as many ploughs of 4 oxen as villans, and at that rate, the normal villan holding 30 acres and having 2 oxen (p. 85), altho' he allows his average villan of D. B. with 2 I acres the same (?) number, but more or less on a scheme of 8 oxen to 120 acres. This infallibly breaks down in detail In some when tested, for as evidenced by the figures for 9 respects counties, the lord had at least $\frac{1}{4}$ of the total ploughs in demesne, and in the recorded counties were some 78,000 ploughs (see pp. I 2 I-2) ; supposing therefore Seebohm's method, which I gather to be that the demesne ploughs were of 8 oxen, and the tenants' ploughs of $4, *$ then would there be 12,500 large ploughs of the lords for $1,500,000$ acres, and

* The following examples do not necessarily, but may Oxen per sometimes illustrate actual husbandry in $1086:$ D. B. - team the one ox in plough, $21 \mathrm{I} a$; two oxen, 22a, 264b, 307b, ii. 184 ; Domesday. two and a half oxen, twice, but in the same place, see $358 a$; three oxen, 49b, I 1ob; four oxen, $366 a$ (only time found, but half a plough passim); five oxen, 14a, 235a, 278b, 293b; six 


\section{Domesday and Feudal Statistics}

58,333 small ploughs for the $3,500,000$ complemental acres; that is, 70,833 (i.e., $4 \mathrm{I}, 666 \frac{2}{3}$ only by the method of $\mathcal{D}$. B.) teams for $5,000,000$ acres arable, and more particularly 37,500 tour-ox ploughs for $2,250,000$ acres held by villeins, at the rate of about 3 villeins per 4 oxen, which is not agreeable to what he has written about the gebur and normal villein being stocked with a couple of oxen.

There seem to be several sources of error, for the 9 counties table demonstrates the lords' teams were $30 \%$ of the total, and as their scope was more considerable than that of those of the tenantry,

Bordars often had plough oxen, Ic86. there might well be some $\frac{2}{5}$ of the total arable in demesne; also the bordars contributed to the ploughs by the witness of Domesday (fo. $303^{b}$., two bordars with one plough* - no other tenants named; and often together with the villeins), and as already shown the evidence from it is against the teams being other than 8 oxen, that is to wit, whatever the actual mode of husbandry, the teams seem to be reckoned in units of 8 oxen.

Method of Table of Nine

In the table of 9 counties, Taylor's Domesday Counties. Analysis furnishes Glos'ter, and the rest are on the author's responsibility; all ploughs not in demesne are counted on the other side, so that ample correction should be made for the villeinst

oxen, 71 $a, 206 a$; seven oxen, $286 b$; eight oxen (not found nor to be expected); nine oxen, $359 b$; and ten oxen, $366 a$.

* See note on p. II for instances selected from 20 counties.

$\dagger$ The following 64 references from D. B. illustrate the $V$ illani of 1086 : as equated to sokemen, 2096 ; as under sokemen, 
per plough, which, as they can seldom be disentangled from bordars and sokemen, cannot be done with precision. The casts differ somewhat

ii. 392 ; as paying forfeits, 176 ; as cbattels (bore away a rustic Villani who was remaining on 1 virg.) $30 a$; as bolding land at farm, illustrated $127 b$; as paying tithes, $38 a$; freeman who had $\frac{\mathrm{H}}{2}$ now a villan, Domesday. ii. I; as witnesses, $44^{b}$ (de villanis et vili plebe), and ii. 393 ; as rent pajers, $52 b$ (10s. p. ann.), $182 a$ ( 18 villans, 6 bord., and 1 priest render $18 \mathrm{~s}$.), $263 a$ ( 1 villan, $8 \mathrm{~d}$.) ; as fractional persons, 1106 ( $\frac{1}{2}$ a villan), $168 a$ (7 half vill.), $196 a$ ( $1 \frac{1}{2}$ vill.), and $252 a$ ( 4 whole, and 6 half vill.) - the partition seemingly in reference to amount of services due; as paying relief on royal Manors. $30 b$ (20s.), i 81 a (an ox); as paying gheld, 203a; as rendering custom, ii. 5 (a villan had $\frac{\mathrm{H}}{2}$ and rendered custom); certain villans quit from all thing of the Sheriff, $30 b$; as bolding or kneing beld lands, $26 b$ (the villans held it T. R. E.) ; $40 a$ (the like); 4 I $b$ ( $4^{1}$ vill. hold and held it); 416 ( 28 vill. hold and held it; no hall); $73 b$ (the villans hold it); $175 a$ (the land was of the demesne of the villans); and $273^{\circ}$ (other 3 carucates of land are of the villans); as with specified boldings, $12 b$ (30 vill. held 4 solins, T. R. E.), $29 a$ ( 1 vill. holds and held 1 virg.), 192a (8 vill., $7 \frac{1}{2}$ ac. each), 1986 ( 5 vill. hold 25 s. worth of land), ii. 3 ( 1 vill. holds 30 ac., another 15 ac.), ii. 5 ( 1 vill. had $\frac{M}{2}$ ), and in Hanwell and West Bedfont, co. Midd., are 3 vill. with 2 Hides cach, the highest amount writer has found (see p. 131); as to Status, $41 a$ (a certain prefect held $; 3$ Hides, 2 of them as a villan), 41 a (Aluric held 3 virg. as a villan), 68a ( $5 \frac{1}{2}$ Hides held by men of the church serving as villans), compare $175^{\circ}$ (making services as other freemen), $269 b$ (thanes working as villans), and ii. 145 (6 free villans); as to Servile work, 17a (the burgesses worked like vill. at the court), $166 a$ (the reeve has I $\frac{1}{2}$ villans), I $82 a$ (the men of another vill labor in this one), 2466 ( 8 burgesses working as other villans), and 2916 (the work of the villans pertains to Saxebi in Lincs.); as to number of plough oxen varying from none to $3 \frac{1}{2}$ pls. to 3 villans ( 1826 ), which may be compared with $180 a$ (I bordar, I pl.), -in certain cases it might appear the villan had 2 pls., but such (21b, 317a, and 327a-Hugh has 1 vill. and 2 pls.) 


\section{I49 Domesday and Feudal Statistics}

from Prof. Maitland's, who claims no minute accuracy for his great industry ; at the same time let not his statement detract from their worth for practical ends, as his tables are of the utmost value, and based, so far as I have discovered, on a sound knowledge of Domesday's method, which entitles his work to the grateful acknowledgment of all interested in our ancient Record.

Yorkshire

Agriculture from the I297 Subsidy Rolls.

An example offers in the 1297 Subsidy (Vol. I 6 Yorks Record Ser.) where from the editor's epitome in the Introduction are 1,044 oxen and $68 \mathrm{I}$ horses, against just under 5,000 qrs. of corn

seem to be instances where the lord is whole or part owner ; the following show extreme cases as found : II 5 a (I vill., I pl.), $164 b$ ( 15 vill., 15 pls.), I $85 a$ (I vill., I pl.), $325 a$ (1 vill., I pl.), $327 b$ (I vill., I pl.), and $323 a$ (5 vill., with $\frac{1}{2}$ pl.), $328 a$ (Io vill. 2 bord. with I pl.), 353a (I I vill. with I pl.), and frequently with none; as to sowing the lords' land with their own seed, $174 b$ (bis), 179b (36 vill. 10 bord. plough and sow 80 ac. wheat, 71 ac. oats), and $180 a$ (238 vill. ploughed and sowed $140 \mathrm{ac}$; now $224 \mathrm{pl}$. and sow $125 \mathrm{ac}$.), which Prof. Maitland gives as instances (p. 57, 'D .B., and Beyond') of the light work of the 1086 villani, omitting to observe that it is not the fact of ploughing the demesne (matter superfluous to record), but of sowing the ploughed acres with their own proper seed, which is worthy of note-thus in A.D. II 24 (A.S. Chron.) the acre's seed of wheat ( 2 bush.) sold at 6s., that of barley (3 bush.) at 6s., and that of oats (4 bush.) at 4 s. in a very dear year, whereas the cost of aration would scarcely exceed 2 d. per acre. That the villani did not till as much demesne land in 1086 as in the thirteenth cent. follows as a matter of mere necessity, by reason that they had fewer ploughs and less land (actually, and also relatively in proportion to the demesne) at the former period; the demesne ploughs then were probably some $\frac{3}{10}$ of the total, and the lords' arable presumably $\frac{2}{5}$ - of course these proportions would be quite inapplicable to the latter period (see P. 152). 
and pulse, when a Michaelmas taxation was ordered to be made on all the goods in the house and fields; taking the oxen alone (on the I 20 acre theory), there would be some I 5,000 acres tillage, and if but 8,000 of them had been sown, a return of 5 bush. p. acre : as some $\frac{4}{5}$ of the crop was oats, 4 (of 5) bush. would have to be kept for seed, nor is it very unlikely that some of the horses were joined in the plough, which would further increase the area and lessen the yield per acre. There were but 370 qrs. (say $\frac{x}{13}$ of sown crops) of wheat (frumentum), 465 qrs. rye (siligo), * and $102 \frac{3}{8}$ qrs. of barley, which if all malted would but yield about i 8 gallons p. annum per record man, and makes out but poorly in comparison with Prof. Maitland's $2 \frac{1}{2}$ gallons per day for same : in conclusion it may well be allowed that the tax-payers would probably better conceal their corn than live stock, but scarcely to the enormous extent needful for the above supposition.

In the E. H. R. (V. 9, pp. 4I 7-439) Prof. Maitland has very handsomely recorded the results of a search in divers records relating to the Manor of Wilburton, with a result of perhaps the best Manor of article on Medirval† Agriculture extant (at any rate known to the writer): this paper alone would prove the unreality of the 120 acre theory, and as

* The accomplished editor (Wm. Brown, B.A.) turns the rye into wheat, and then explains the absence of the former : the point is not what a word may sometimes mean, but what it represents in a particular record, taking into consideration the sense and date.

$\dagger$ Walt. de Whytlescyc's Hist. containing extents of over a score of Manors, discovers their structure far more lucidly than the usual modern explication. 


\section{5 I Domesday and Feudal Statistics}

the evidence (quite unconsciously of course) is given by an author who is at great pains to support the opposite (D. B. and Beyond), an epitome of the matter in aforesaid magazine is here appended.

In 1086 (D. B.) the Manor of Wilburton had 3 ploughs in Demesne, in 1277 there were 216 acres arable; t. Ed. II. 4 ploughmen (i.e., 2 ploughs), and 128 acres reaped; in 1426,246 acres arable: as to the Villeinage in 1277 were I $5 \frac{1}{2}$ full lands, of 24 acres each, total 372 acres, which Prof. Maitland particularly notes as being Details equivalent to statute ones; $t$. $E d$. $I$. for winter from it refute scholastic theories of Agriculture. and spring ploughing were due from each full land one ploughing (the work of one man for one day, but each 2 ploughings reckoned as I diet) per week for 28 weeks ( 30 less 2 at Christmas) - total by theory 434 , and noted as actually done in 4 consecutive years, $420 \frac{1}{2}, 406,377,406$,- - say 400 winter and spring ploughings p. a. The amount of ploughing not being given, let it be supposed that 2 ploughings (i.e., the work of 2 men for I day) yield an acre; then ( $t . E d$. I.) are some 200 acres (once ploughed) performed by the villein teams alone, taking no account of 5 free tenants, who owe 5 days tilling each. In 1381 the full lands each owed I day's Somererthe (I acre per day), 2 days' Nederthe (I acre, as $\frac{1}{2}$ acre each day), and all the tenants owed 2 boon ploughings (bringing all the oxen they had), which latter with almost certainty they may have been said to owe $t . E d$. I. ; in $t$. Ed. II. Prof. Maitland states that about 5 s. per an. ( 2 d. a plough each day) was expended as regards, for the boon ploughers 


\section{Agricultural Statistics}

for their 16 (sic) ploughs : the above can leave no room to doubt that at least half of the 216 arable acres of the demesne was completely tilled by the tenantry, leaving at most 108 acres for the 4 hired ploughmen named t. Ed. II., and further the husbandry here must have been far more thorough than that set forth in Walter de Henley's work on Agriculture, as each acre at Wilburton would on an average be ploughed twice or more, instead of the almost incredibly scanty aration of the bailiff knight.

The Kentish Manors of Rochester Cathedral Great (Custumal Reg. Roff. I290-I320 A.D., publ. increase of I 788) illustrate the note on p. 149 of this vol., tenantry. and the following table demonstrates that in them (1290-1 320) the demesne teams are practically the same as Domesday, whereas those of the villeins have more than doubled,

Ploughs (1086).

Dem. Ten.

\begin{tabular}{cc}
1 & 12 \\
5 & 11 \\
1 & 1 \\
2 & 4 \\
2 & 6 \\
6 & $14+(? 1)$ \\
\hline $17+49=56$ \\
\hline
\end{tabular}

Manors.

Southflect

Frendesberie ...

Dcintonia

Stokes...

Wldeham

Heddenham (co. Bucks)
Plougbs (1 290-1 320).

Dem. Villeinage.

Rochester

Manors 1086, and c. Ed. I.

and further it may be noted that in Southfleet, 25 juga plough 50 acres, besides 2 precations (of I acre per plough), total 86 acres; Frendesberie, Plough 2 I juga plough $21+16$ acres; Deintonia, 3 juga, due there3 acres plough 6 acres and 6 quartulas; Stokes, from, at 


\section{I53 Domesday and Feudal Statistics}

9 juga plough 9 acres; Wldeham, ro jugas each

2 acres per plough, and $6 \frac{1}{2}$ jugas (of the 10) a further $6 \frac{1}{2}$ acres ; precations only noted in Southfleet, but perhaps demandable in the other Manors. 68 juga therefore possess $6 \circ \frac{1}{2}$ ploughs, or $I$ plough to 45 acres, and in no case more than 4 acres recorded as done in addition on the demesne: that the jugum is computed at 40 acres is obvious from entries on p. 6, thus- 2 juga pay $8 \mathrm{Id}$. gavel, $\frac{1}{2}$ jugum 2od., $8 \frac{1}{2}$ acres $8 \frac{1}{2} \mathrm{~d}$., 3 juga and 14 acres I Is. 2d., * etc.: from p. Io it appears the reeve must be a virgater (Heddenham, co. Bucks), and during office has 4 oxen in the lord's pasture.

Agricul- I would further submit that tenants of 2 virgates lural details of the rath and $13^{\text {th }}$ centuries. may easily be rated at 8 oxen, of I v. at 4 oxen, and of lesser quantities, in proportion (more or less), at any rate in the 12 th and $13^{\text {th }}$ centuries, and that these amounts were sometimes exceeded, in support of which as follows. In the Burton Chart. A.D. I I I4 (p. $30 \mathrm{Wm}$. Salt Soc. Coll., Staffs) a note of 4 virgates inland, that is land of 2 pls. which are there with I 6 oxen; in II 89 custumal of Glastonbury (Roxb. Soc.) men of 3, 5,10 acres, and $\frac{1}{2}$ virgate all plough at precations (pp. 22, 6I-2), a 3 acre man to join his ox if he has one (p. 28); 17 virgaters to plough each with 8 oxen (p.123), and in a later. custumal of

* The rate is of course Id. per acre, but (as may be observed from the note on pp. 8,9 , in this vol.), the most simple agricultural arithmetic is apt to bewilder the erudite,--hence an explanation (deemed advisable to clear the morning mists from the learned mind) which for the ordinary reader would be esteemed entirely superfluous. 
the same Abbey A.D. I235-6I (Somerset Rec. Soc.) I 7 tbree acre men are each to come with their plough and what oxen they have (p. 204); I 8 five acre men each with one ox or more if possessed (p. 78); I 3 ten acre men each with a plough and what oxen he has (p. 74); 9 balf virgaters are to plough and find 2 oxen each (p. I 30 ) ; I 3 ditto each to join their oxen for ploughing (pp. I 49-I 50); 2 ditto each with 4 uxen if owned (p. I 82), and 20 ditto each to plough with 8 oxen if possessed (p. 2 I0), 2 I virgaters each if he has 8 oxen (p. $5 \mathrm{I}$ ), to find 4 oxen (p. 82), 50 ditto each if he has a full plough to himself (p. 108); 9 ditto each if he has a full plough (p. 165), with 8 oxen if he has then (p. I 89), to find 8 oxen and himself with a rod superintend his ploughmen (p. 210); a $\frac{1}{2}$ Hide man (given $\frac{1}{2}$ acre man, an obvious slip) to come with ploughs (p. I 33 ); and one with 2 virgates plus $I O$ acres to be beside his ploughs at precations (pp. 83-4). On P. I4I of the II 89 custumal occurs as under: "Walter de Hennelea holds I virgate for 8s., and ought 9 times in the year to plough on his lord's land, with a whole pl. if he has it, and with $\frac{1}{2}$ pl. if he has not unless half, and with 2 oxen if he has no more "- and three others likewise hold and work as said Walter. It will be observed the name is the same as that of the Dominus whose exposition heads this chapter, and whom Prof. Rogers was the (or one of the) first to exploit ; this find seems to have had "no luck" in its exponents, and the discoverer cannot but have smiled at the discomfiture of his compeers in 
155 Domesday and Feudal Statistucs

their interpretation of "La Dite de Hosbanderye "; as himself (p. 75, Six Centuries, etc., Rogers) remarks, "By this he means, not that a team is engaged in ploughing all the year round, but that if it were so engaged, it would cover the space of an acre a day," and further, the same writer assesses the Manor of Cuxham, known to have 3 ploughs at 250 acres or thereabouts (Hist. Agr.), and not at 160-1 80 multiplied by three; nevertheless, after pointing out the remark cited (p. 75, Six Centuries) I have been informed that certainly Rogers assumes 240 acres ploughing per team, the truth of which must be left to the judgment of any candid reader.

These custumals (Glastonbury as cited) show Demesne the fallacy of supposing that the ploughmen spent had divers every hour of the week days in 44 weeks in conduties. tinued aration; and also the status of the carucarii as being often 3-5 acre men (passim), and once $\frac{1}{2}$ virgaters (p. 70 Som. Rec. Soc.) ; and the cessation of villein services for 3-4 weeks at Christmas, Easter, and Pentecost, is matter notorious (Ramsey Chart., Boldon Buke, St. Paul's Domesday), and further, the teamsters had to work their own land. $\mathrm{Bad}$ weather and frost stopped ploughing (it seems necessary to make this statement explicitly; see Ramsey Chart.; p. 64 Roxb. Soc.; pp. 12, 65, I60 Som. Rec. Soc.), and in the later Glastonbury record both holder and driver are noted to have the private use of the lord's team for one day in the week, by turns each (pp. 70, 94, 217 ); for 2 out of every 3 Saturdays (p. 63) ; further, the ploughmen carry hay and prepare the lord's malt 
(p. 94), and work in the harvest field (p. 167 ; also in the appendix to Hatfield's Survey circa I 348, under Bailiff's A/ss, and in the Manor of Gravesend, see Cruden's History of same), and thresh in the barn (Bailiff's $A /{ }^{c s}$ in Hatfield's Survey, Surtees Soc.), and by negative evidence of the last named reference, harrow and set out and spread dung, as these items are not burdened on the account.*

Nowadays broadly speaking every 100 acres Impracof land ( 47 arable, 53 grass) has some 4 men, but ticability of in 1086 there were not unless 3.56 of recorded Sheory. $_{\text {theol. }}$ population per team; if each ploughland really had been 120 acres arable, and if all those noted were actually manual labourers (an extravagant postulate), then would there have been but 3 men per 100 acres all arable, and none whatever for the work of pasture and meadow. Now altho' the crops then raised do not compare with the present yield, it must be borne in mind for each 8 and 4 ox plough 2 men would be engaged (all the year round as by theory), and if ploughs of 2 oxen are to be considered, at least at the rate of 4 men occupied in tillage per each 120 acres, which exceeds the 3.56 found; whereas at this present one ploughman would (in the North at least) usually suffice each team ; and further the mowing machine surpasses the scythe, the reaper the hook, the steam threshing-machine the flail, and

* Harrowing is sometimes noted, but where not accounted for, the presumption is that the servants of the Manor performed the operation. 


\section{Domesday and Feudal Statistics}

so forth as to other labour saving economies unknown T. R.W. Then supposing 3.56 men really aid work 120 acres arable plus the supplemental grass land, it is difficult to conceive how at hay time and harvest the $I \frac{1}{2}$ men (for by hypothesis the other two are ploughing) even with the assistance of women, etc., would get in the crops, and supervise the stock at pasture; whereas it appears that in I 348-9 (Bailiff's A/cs Manor of Quaringdon) a harvest of some 160 acres was got in in 4 weeks ( 23 days) by 8 hired men in the Ist and 2nd weeks, 40 in the 3 rd, and 20 in the last, at a cost of $5 \mathrm{~d}$. and $4 \mathrm{~d}$. per day per man, with doubtless unnoted assistance from women, etc.

Manor of

Cuxham.

In the Manor of Cuxham ( 7 Ed. I., Rot. Hund., and 26 Ed. I., Rogers' Hist.. Agr. citing Survey) were 2 carucates of land in demesne with works of 8 half virgaters in $12 \% 9$, but in 1317 (Bailiff's $A /{ }^{\circ}$ ), and I 332-I $35^{\circ}$ (Rogers' Hist. Agr. presumably from uncited $\mathrm{A} /{ }^{\mathrm{cs}}$ ) were 3 ploughs cultivating a varying acreage of some 170 sown acres, which Rogers has extended by fallow as 232 ac. (I 332-3), and $25^{8}$ ac. (I $35^{0-1}$ ), which of course is an estimate.

Manor of In the Manor of Cotum (Bailiff's A/cs, I 348-9, Cotum.

Hatfield's Survey) were in demesne 27 oxen, 4 horses, 6 ploughmen, and at least 3 pls. (six or more noted in the $A / c)$, I 89 sown acres by weeding, and by seed $A /{ }^{c} 69$ ac. Wheat, I IO ac. Oats plus some 4 qrs. of Peas sown; in c. I $377-80$ (Hatfield's Survey) the total arable is returned as 242 acres.

In the Manor of Quaringdon (same ref. date 


\section{Agricultural Statistics}

1 348-9) were in demesne 27 oxen, 3 horses, Manor of 6 ploughmen, at least 3 pls. (others named in $\mathrm{A} /{ }^{\mathrm{c}}$ ) Quaring. with 164 acres by reaping, and by seeding 66 acres Wheat, 88 ac. Oats, and 9 sown bush. of Barley but no fallow defined; the gaps and omissions in these $\mathrm{A} /{ }^{\mathrm{cs}}$ do not give sufficient data for the other Manors.

The areal carucate as shown varied from 60 to I60 acres (H. R., I 279) in co. Beds, but in St. Paul's Domesday (Camd. Soc.) in 1222 are 720 acres in demesne by 3 pls., to wit 3 carucates of 240 acres each, that extent being possible by the large services owed by the tenants on some 5,000 acres on the old Manor of Adulfsnasa, of Manor of which Waleton was a portion, with Thorpe, Horlock and Kirkby. To the writer on ancient Agriculture it is perhaps all one whether a plough goes 60 acres or 240 in the year (or at best accounted for by lighter and heavier soils); ${ }^{*}$ not so however in actual practice, nor yet in records, if read with care and discretion.

There appears formerly to have been consider- Mediæval able variation in agricultural measures, and it is of agricul. probable that a change in the quasi-standard quarter ture. occurred $t$. Hen. III., in which reign it seems to have had 8 bushels, each weighing (for wheat) c. $64 \mathrm{lbs}$. Troy, such pound containing 7,680 wheat grains $\dagger$ " taken in the midst of the ear." This

* The comparative rainfall has a much greater influence Rainfall. under this head, as by the number of days in a year in which land can be worked.

$\dagger$ Vide Statutes cited as $5 I$ Hen. III.; $3 I$ Ed. I.; and t. Hen. III. 


\section{59 Domesday and Feudal Statistics}

lb. W. Chaffers* states to have been used by the Saxons, and known as the Cologne pound; whether or not there was a qr. of wheat in England composed as above prior to Hen. III. I may not pretend to discern, but certain it is that $t$. Hen. II. and John, a quasi-standard quarter existed which was of $\frac{1}{2}$ (or less than $\frac{1}{2}$ ) the dimensions of that under notice. Two writers on agriculture (see Walt. de Henley, ed. R. H. S., and the more valuable anonymous Husbandry incorporated in same vol.), both perhaps $t$. Hen. III. evidently use the larger qr. [vide feeding rations and seed sown in vol., ut sup.); and a like one occurs in the Rules of Robert Grostete (who died $t$. Hen. III.) as appears from the statement that I 80 loaves (white and brown together), each weighing 5 marcs $(25,600$ grains), are made from a quarter of wheat in his Household; at this present an average qr. of Wheat, Barley, and Oats may be taken at 500 , 440 , and 336 lbs. (avoirdupois, 7000 wheat grains each) respectively; this modern pound presumed to be somewhat heavier than the older one of 64 to the bushel. That the quarter from $\dagger 7680$ wheat grains was not $t$. Hen. II. and John the quasistandard one appears from divers entries on the Misce Roll (14 John), as to the travels of the King's cart horses, which are each allowed I bushel+

* Hall Marks on Plate.

+ Id est, $7680 \times 64 \times 8$ wheat grains per qr.

It is, of course, not intended to convey that cither 62 or 31 modern lbs. of corn was consumed per horse; in I26I-I270, the larger qr. seems to have sold (for oats) at 2s.: there is no particular occasion to suppose an overstrained morality either on the part of King John's grooms, or on that of the servants of the hostels. 
of oats (price rod. to Is. per qr., and in some cases provably of 8 bush.); this smaller measure would appear [vide entries Rot. Pip. I7, 19 and 20 Hen. II., where quarters are named] to have been somewhat an equivalent of the contemporary horseload, always bearing in mind that the burden of a sumpter cannot be precisely equated with a measure of capacity, owing to the differences in weight of Wheat, Barley, and Oats (ut sup.). Taking the qr. of Hen. III. onwards as being of like capacity with the present (an assumption), its contents would have had rather less actual weight (the smaller grains being relatively lighter), and the other much smaller quarter of Hen. II._- John would more or less be the actual load of a horse, which is the "standard" measure in the Pipe Rolls of the former reign. The allowance of a destrier t. Ed. I. (Wardrobe $A /{ }^{c s}$ ), is $\frac{1}{2}$ bush. of oats (of course with sufficient hay), but a war horse it must be noted might have to carry a considerable weight of iron armour (up to $36 \mathrm{r}$ modern lbs., * cited for a barded horse, I 560, in Scott's Brit. Army); for a cart horse $\left(W . A /{ }^{c s}\right) \frac{1}{4}$ bush., which bearing in mind that beans were not supplied, and that the bushel was probably somewhat light (as by modern weight) is not inconsistent with present practice ; the professed antiquary, however, should note that I bush. of corn per horse ( 14 John, ut sup.) in the measure of A.D. I900, is just as inapplicable as the $I 20$ acre plough theory, merely proving the unlikeness of the quasi-standard ( $t$. John) to our own. Walt. de Henley's allowance of $\frac{1}{6}$ bush. ( $t$. 'Hen. III., hence rather short of modern weight) of corn with

* This includes the rider. 
I6I Domesday and Feudal Statistics

hay and chaff only, would be a defective winter ration for an average modern farm horse; but, the anonymous writer on Husbandry (in same vol.) appears to give an intelligent record of the practice of his own district: his information can be extended, in matters like the gestation of animals, the terms in that item being nearly agreeable with modern averages. There must of course have been many ancient local variations of measure, not coincident with the quasi-standard: horse loads and bushels were used as measures $t$. Hen. I. [Pipe Roll and Chron. Pet.], and a modius in 1086 $(D$. B.), apparently of considerable capacity $[t$. Hen. I. app. Chron. Pet.] : the rendering of the term seedlip (I I 24,A.S. Chron.), as bushel in the note on p. I 49 must not be taken as evidence of the then existence of a measure so called of like capacity with a modern $\frac{1}{8}$ of a qr., but it seems to demonstrate there was in II 24 an antecessor of the modern bush., by whatever name called, of like dimensions - the curious achersetum (presumably seed, for one acre), of the Peterboro' Inquisition ( I $125-8$ ) may also be noted. 



\section{University of California}

SOUTHERN REGIONAL LIBRARY FACILITY

405 Hilgard Avenue, Los Angeles, CA 90024-1388

Return this material to the library

from which lt was borrowed. 


\section{|||||||||||||||||||||||||||||||- 31210000395044}

C SOUTHEAN REGIONAL LIBRARY FACHTY 
